
Approaches to Social Inequality and Difference

\author{
Series Editors \\ Edvard Hviding \\ University of Bergen \\ Bergen, Norway \\ Synnøve Bendixsen \\ University of Bergen \\ Bergen, Norway
}


The book series contributes a wealth of new perspectives aiming to denaturalize ongoing social, economic and cultural trends such as the processes of 'crimigration' and racialization, fast-growing social-economic inequalities, depoliticization or technologization of policy, and simultaneously a politicization of difference. By treating naturalization simultaneously as a phenomenon in the world, and as a rudimentary analytical concept for further development and theoretical diversification, we identify a shared point of departure for all volumes in this series, in a search to analyze how difference is produced, governed and reconfigured in a rapidly changing world. By theorizing rich, globally comparative ethnographic materials on how racial/cultural/civilization differences are currently specified and naturalized, the series will throw new light on crucial links between differences, whether biologized and culturalized, and various forms of 'social inequality' that are produced in contemporary global social and political formations.

More information about this series at http://www.palgrave.com/gp/series/14775 
Cecilie Vindal Ødegaard Juan Javier Rivera Andía

Editors

\section{Indigenous Life Projects and Extractivism}

Ethnographies from South America 


\section{Editors}

Cecilie Vindal Ødegaard

University of Bergen

Bergen, Norway
Juan Javier Rivera Andía

Universitat Autònoma de Barcelona

Barcelona, Spain

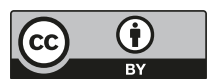

Approaches to Social Inequality and Difference

ISBN 978-3-319-93434-1 ISBN 978-3-319-93435-8 (eBook)

https://doi.org/10.1007/978-3-319-93435-8

Library of Congress Control Number: 2018954928

(C) The Editor(s) (if applicable) and The Author(s) 2019. This book is an open access publication. Supported by the University of Bergen.

Open Access This book is licensed under the terms of the Creative Commons Attribution 4.0 International License (http://creativecommons.org/licenses/by/4.0/), which permits use, sharing, adaptation, distribution and reproduction in any medium or format, as long as you give appropriate credit to the original author(s) and the source, provide a link to the Creative Commons license and indicate if changes were made.

The images or other third party material in this book are included in the book's Creative Commons license, unless indicated otherwise in a credit line to the material. If material is not included in the book's Creative Commons license and your intended use is not permitted by statutory regulation or exceeds the permitted use, you will need to obtain permission directly from the copyright holder.

The use of general descriptive names, registered names, trademarks, service marks, etc. in this publication does not imply, even in the absence of a specific statement, that such names are exempt from the relevant protective laws and regulations and therefore free for general use. The publisher, the authors and the editors are safe to assume that the advice and information in this book are believed to be true and accurate at the date of publication. Neither the publisher nor the authors or the editors give a warranty, express or implied, with respect to the material contained herein or for any errors or omissions that may have been made. The publisher remains neutral with regard to jurisdictional claims in published maps and institutional affiliations.

Cover Photo (C) P_We / GettyImages

This Palgrave Macmillan imprint is published by the registered company Springer Nature Switzerland AG

The registered company address is: Gewerbestrasse 11, 6330 Cham, Switzerland 


\section{Preface}

Extractivism is a good way to summarise the last five hundred years in South America. When Indigenous people discovered Spanish explorers on their coasts in the late fifteenth century, the strangers had arrived in search of precious metals and spices. Mercantilist policies at the time sought to increase wealth and power through trade and the accumulation of gold and silver. Proselytism accompanied the extraction of natural resources and, as Europeans moved into the continent, they employed religion and force to coerce Indigenous labour. Native people became the workers who first panned for gold in the Caribbean and then mined silver in northern New Spain (Mexico) and at Potosí, a high plateau in what is today Bolivia. Native labour made extractivism possible throughout the Colonial Period and, with millions of African slaves, facilitated Europeans' appropriation of raw materials. The extraction of resources, forced labour, and European colonisation created the South America we know today.

Independence and the creation of nation-states in the nineteenth century was an opportunity for people in South America to take ownership of their own resources. The Americanos, those upper-class Europeans born in the Americas who employed nativism to procure support for their wars to gain freedom from Europe, were at first unable to extract minerals because the devastating wars for political freedom had filled in mines, destroyed ports, and damaged the infrastructure. Once the elite overcame decades of political struggle and began to turn a profit, they faced additional obstacles. The high cost of mass production, along with the legacy of 300 years of exchanging raw materials for manufactured goods, challenged an industrial take-off. Border conflicts, Indigenous insurrections, 
and political disarray among the elite further inhibited industrial advances. In sum, the nineteenth century perpetuated the extractivist legacy and challenged South American attempts to forge new economic models for their young nations.

Native people again played an important role as the labour force that made extractivism during the Neocolonial Period of the late nineteenth century so lucrative for the elites who sold their raw materials, as well as for the foreigners who purchased them. The chapters in this book show that by the turn of the twenty-first century, extractivism had shifted to minerals, petroleum, and water. One century earlier, companies instead extracted raw materials, fruits, and plants. Indigenous people tapped rubber latex in Amazonia and harvested yerba mate tea in Eastern Paraguay. They mined copper in Chile and harvested coffee in Colombia. Native workers harvested cotton in northeastern Brazil, collected cochineal snail shells for dying textiles, and guano along northern Pacific coasts of South America. As in the Colonial Period, Indigenous workers extracted the raw materials that changed the lives of millions of people in the developed world and enriched the elite in South American nations.

States and companies during this period mobilised Native people for extractive labour. To extend coffee, Guatemala divided communal Native lands into individual lots and sold the surplus in 1877, forcing villages to send the number of workers that planters requested for 60-90 days of the year. ${ }^{1}$ Labourers migrated to the coffee fincas in the lowlands to clean the groves and harvest the beans. Conditions were often violent: managers called Native workers chuchos (dogs) and beat them with fists, whips, machete flats, attacked them with dogs, and held them in stocks or finca jails to force their work. Labour recruiters stole from the workers, kidnapped wives and children, and burnt their houses to force compliance. Planters employed indebted peonage and, by the 1920s, most of the men in the Native villages owed substantial debts to estate owners. ${ }^{2}$ As a result, highland Indigenous people lost the ability to subsist on their own crops and became permanent workers on lowland coffee plantations where they had to buy food.

The demand for Amazonian rubber grew during these years and, by 1907, Peruvian entrepreneur Julio Arana was employing brutal measures to force the Huitoto people in Peru's eastern forests to harvest caucho (rubber latex). The company used torture and terror to extract 4000 tonnes of caucho by 1910 at the cost of 30,000 Native deaths. ${ }^{3}$ Surrounding Manaus on the middle Amazon River, where Henry Ford was extracting 
caucho and where rubber barons built the famous opera house, rubber tapping led to the untold misery of thousands of Native people. A similar example took place in Eastern Paraguay, where the Paraguayan Industrial Company employed debt peonage to force the Guaraní to harvest yerba mate under dismal conditions. ${ }^{4}$ These labour arrangements became common in South America, yet labourers who made such extraction possible largely did not enjoy the benefits of the profits.

Native people during these decades faced liberal administrations' intent on displacing them in favour of extractive industries while still using their labour. Politicians wanted land, resources, and labour to extract export crops such as coffee, rubber, bananas, and henequen (Agave fourcroydes Lem.). In areas of larger Indigenous populations and histories of racial mixture, liberal rulers divided Native communal territories, took their lands for agriculture, and created pools of landless workers to serve national labour needs. Technological changes also altered Indigenous lives. Transportation and communication systems, developed rapidly during the Neocolonial Period to facilitate extractivism, enabled broader interrelations between Native leaders and communities. The use of Spanish as a lingua franca allowed communities to better communicate and organise their responses.

In some nations, Native people fought extractivism. The Yoeme in Sonora, Mexico, used guerrilla warfare to counter Porfirio Díaz' attempt to sell their resources in a long struggle against forced labour and takeovers of their lands. By the first decade of the twentieth century, US ranchers were extending crops and vegetables for the California market onto former Yoeme lands. The so-called broncos (a pejorative term meaning 'wild') Yoeme attacked the ranches moving into the territory and hid in the eastern mountains of the Sierra Madre Occidental Range. They vowed to die before giving up their lands, even when Federal troops butchered women and children with Mausers (semi-automatic guns) and deported them to hard labour camps far south in the Yucatán. ${ }^{5}$

While Indigenous people could not completely unite against liberal attacks, they employed some alliances strategically to counter outside threats to their lands and resources. Rather than always opposing liberal rule, Native people more often tried to shape specific political policies to assist in their own goals, even if their lobbies at times resulted in cooptation by the nation. Sometimes Indigenous people signed agreements against their will to appease outside forces. In other cases, compliance and cooperation proved viable alternatives to costly violent resistance, 
and communities employed legal systems to address local grievances by taking opponents to court. Native soldiers, at times, participated in wars to further their territorial claims and gain recognition as citizens. During the War of the Pacific, precipitated by conflict over the extraction of saltpetre (guano), Native peasants in Peru's central highlands provided the foundation of resistance against occupying Chilean forces. Mapuche warriors in the south, despite their long history of hostility towards outsiders, volunteered to fight alongside Chilean forces against Bolivia and Peru to gain recognition of their tribal lands, distinctive ethnic identity, and vision of a pluralistic, inclusive nation. ${ }^{6}$ Native resistance provoked military reprisals and even drastic national measures, such as a gigantic trench for literal physical separation in Argentina that ultimately failed.

Broadly speaking, Indigenous communities nuanced their responses to liberal extractivism. Some Indigenous people joined the majority society and changed their traditional ways of life, even as they employed political alliances strategically to counter outside threats. Others took advantage of specific policies even if their allegiance resulted in accommodation. When extractivism severed too many Indigenous people from their lands, as it did in Mexico under the Díaz Regime, untold numbers of impoverished Native people fought in the Revolution that toppled Mexico's dictator. The war (1910-1920) resulted from Mexico's sale of natural resources to foreign companies, an extraction process facilitated by menial Indigenous labour during the Díaz Regime.

Although they assisted in frontier development and, at times, supported political changes, Native workers, nevertheless, usually saw few visible gains beyond greater collective consciousness and ethnic strength. Even peaceful contacts still resulted in decimation by disease. A few peoples negotiated treaties for limited regional autonomy or even sent leaders to key positions in national administration and politics. In most places, though, Native peoples instead sought to distinguish themselves from the state and defend their lands.

By the time the Great Depression struck in 1929, Indigenous communities throughout Latin America were helping to influence national events. The economic collapse terminated Neocolonial extraction and forced nations to turn inward, rely on their own resources, and industrialise as never before. Attempts to divert natural resources to domestic production meant new interaction with Native people. Changing media, technology, and participation in military conflicts inevitably altered Indigenous ways of living. Following the Great Depression, Native people pushed for greater 
political participation and a role in shaping policies. During these years, Indigenous communities in Northwestern Argentina organised themselves while harvesting sugarcane, Native people helped to shape Brazil's exploration of Amazonia, and Indigenous people joined forces with tin miners during the National Revolution of 1952 to change politics in Bolivia. Extractivism and national events fomented Native interaction with outsiders and other communities, altering Indigenous ways of life and encouraging additional pan-Indigenous organisation.

Some Native peoples sought to retain cultural differences from national society, as well as to defend the lands that allowed them a measure of economic independence. The Pilagá in Northwestern Argentina, in 1947, lost their work in sugarcane and cotton fields to a drought and grasshopper swarms. Five hundred Pilagá gathered in October at the community of La Bomba, in western Formosa Province, around a religious leader named Luciano. The dynamic prophet promised that their bibles would stop the bullets if soldiers should attack the assembled Pilagá. Worried over a large Native gathering, though, Argentinian troops killed as many as 1500 Pilagá people in two months, using prevailing fears in the area of Indigenous organisation to decimate the group.

Despite lingering massacres, Native labour continued to make possible the extraction of resources and contributed to economic growth and political changes throughout the twentieth century. Pressure by Indigenous people and peasants to recover land and defend resources threatened by foreign business interests strengthened the Guatemalan Revolution of 1951, the Cuban Revolution of 1959, and the Nicaraguan Revolution of 1979, a popular reaction to Somoza's failed policies. In these and other ways, Native people shaped national events in response to extractivism in their territories.

As the Cold War shaped the nations and conditions in which they lived, Native peoples continued to assist in the removal of natural resources as governments sold commodities to the contending superpowers and used the income to reward their supporters. The military regimes that spread throughout much of the continent during the Cold War exploited the remaining forested areas, especially Amazonia, to build huge hydroelectric plants that lit up their cities. Petroleum drilling, gold prospecting, and mineral extraction were extended into the few remaining unexploited areas of the continent, again often to Indigenous lands. There were important changes, however, which nuanced Indigenous responses. Some peoples, such as the Kayapo along the Xingu River in eastern Amazonia, 
allowed miners to work on their lands in exchange for money that they used to alter their communities by purchasing vehicles, televisions, and tools. In the Brazilian states of Amapá and Pará, the Waiapi mined for gold themselves and used the proceeds to fund political organisation and education. Indigenous people now employed additional tools available to help shape extractivism in their territories.

Governments that followed the end of the Cold War in 1991 again emphasised free trade, the production of exports, and comparative advantage. Their Neoliberal programmes, aligned with the Washington Consensus, imposed austerity, sold off natural resources, and privatised state services such as water delivery. These policies produced modest economic growth, unequal distribution of wealth, and plunged many people into poverty. By 1989, according to the United Nations, 183 million Latin Americans lived under the poverty line, and South American poverty levels rose from 31.5 per cent to 38 per cent of the population. The social results were difficult in the largest urban centres where slums multiplied, but living conditions also deteriorated for Indigenous peoples in rural areas. People fought back against neoliberal changes, though, by forming political alliances, employing the media, and linking causes with environmental NGOs to participate more extensively in the new democratic administrations.

Indigenous people continued to organise during the first decade of the third millennium as governments throughout South America rushed to implement free trade and economic reforms. Extractivism especially enabled this latest round of financial gains. The neoliberal principle of comparative advantage gained broad support from Andean nations to the Southern Cone, and leaders, including Fernando Henrique Cardoso in Brazil, pushed free market policies and increased extractivism. Enabled by changing technology and empowered by improved communication networks, Native people mobilised themselves across national boundaries, and states countered Indigenous efforts with further attempts to control them. Neoliberal programmes incentivised states to privatise natural resources, and their political sponsors tried to curtail and co-opt Indigenous organisations and political influence because they stood in the way of such plans.

Joining forces with environmental activists, NGOs, and other disenfranchised minorities, Indigenous peoples continued working to improve their living conditions and defend territories and resources. Their struggles both raised national tensions and gave Native peoples the opportunity 
for greater political participation. Then in December of 2005, Indigenous people in Bolivia elected Aymará leader Evo Morales and his Movement to Socialism (MAS) party to the presidency; Morales was considered by international media as the first Bolivian leader to capitalise on his indigeneity for political gain in that nation with a majority Indigenous population. Part of the growing Pink Tide, a movement by leftist-leaning leaders who pushed a programme of independent political change, Native supporters of Morales proved that they intended to remain important actors within evolving economic, social, and political processes changing South America. Bolivia's Aymara president continued to champion extractivism, however, proving the difficulty, even for Pink leaders, of changing the continental economic patterns that exploited natural resources for national profit.

As the historical precedents indicate, the legacy of extractivism in Latin America is well known, and for years, scholars have organised their histories of the continent around this theme. Noted Uruguayan historian Eduardo Galeano championed the idea in his book The Open Veins of Latin America, which outlined five centuries of removal of natural resources. Galeano effectively portrayed commodities, including coffee, copper, and gold, as the lifeblood of Latin America and as examples of the wealth drained by foreigners and leaving in their place poverty and underdevelopment. His work claimed widespread attention around the world. This new book on extractivism focuses on some of Galeano's themes around Indigenous people and extractivism in South America during recent years. As the editors emphasise, contributors focus on Indigenous peoples as historical actors, rather than as peasants within an exploitative system, as traditional Marxist class analysis has tended to do. In addition, contributors employ anthropological theory and insights to analyse Indigenous experiences and interaction related to recent extractivism. By focusing on regional and even communal realities, explored by anthropologists through participant observation in the Native communities they studied, chapters contribute nuanced insights about people's experiences with current extractivism. These ethnographic studies open different ways to understand recent Indigenous interaction with outsiders and resources.

Chapters in this book also reveal historical continuities within Native responses to outside threats. In recent years as before, many Indigenous peoples remain divided in the face of extractivism. It has been challenging for Native communities to bridge historical barriers in the face of outside appropriation of their resources. Land use, cosmological beliefs, and body practices still link Indigenous people to the land and environment, as well 
as influence their response to threats much as they did in the Colonial Period. Relationships with nonhumans, with whom Native peoples share ownership of the landscape and resources, continue to shape Indigenous cosmologies, plans, and actions.

This collection suggests that relations with political actors and outside institutions also remain vital to Native people as they access power in search of the advantages needed to defend themselves. At the same time, interaction with better-funded outside politicians and businesses has challenged Indigenous organisation. This has especially been the case when extractivism interferes with communal leadership, altering interpersonal relations and Indigenous cultures, much as European rule did in nineteenth-century Africa during that period of European colonial extractivism. Native people in the Andes still struggle to control the outward flow of materials and have found additional advantages through alliances with outside NGO advocates.

Indigenous people in recent decades have organised creatively in ways that defy categorisation, revealing conceptions of progress and wealth that differ from dominant understandings. Defending their own means of production, rather than having to depend on outside markets for resources, has encouraged some groups to continue to value traditions, religious beliefs, and even the concept of moral economies that have empowered political organisation and fostered communal cohesion. Their changing mobilisation helps recreate local forms of relatedness in ways closely linked to extralocal values, such as the cash economy, revealing both cultural continuity and change amidst outside pressures. This book shows challenges that Indigenous peoples in parts of South America have faced as they engage in and make sense of major political and economic changes sweeping their world.

Despite continuities, much has also changed for Indigenous people in recent decades as they negotiate extractivism and interact with expansive states. Profound cultural changes have swept Indigenous communities as companies try to appropriate their resources. Native responses have varied broadly across peoples and communities, and their mobilisation defies easy placement into dichotomised modern-Indigenous and capitalist-traditional categories. Anthropologist Kay Warren, for instance, has argued against the essentialised view that Native peoples belong to a specific past historical period. Indigenous organisation and ways of life reveal, more than ever, that Native people today are part of contemporary society and the capitalist economy. Their political activism and participation in the market 
confirm that Native people should not be essentialised as remnants of the past and as sharing premodern ways of life nor that their identity is formed by a defensive reaction to the dominant culture. ${ }^{7}$

States have issued titles and regulations that affect resources on Indigenous lands. The resulting conflicts have sparked debates over indigeneity and identity that play out in particular organisations of power, with differentially distributed capacities and vulnerabilities. Multiple actors have also 'performed' indigeneity to promote their own ethnic and political agendas, such as opposition to state development of their lands or even to conceptions of gender relations that outsiders attempt to impose on Native peoples. Examples include the quasi-theatrical Native demonstrations in Brazil, in full tribal regalia, conducted to oppose extractivism and the construction of hydroelectric plants in Amazonia. This performance of identification in public spaces has become, in cases, a political tool for challenging the state. As this collection suggests, it remains to Indigenous peoples themselves to define their identity and roles within conflicts over their resources.

At the same time, extractivism has also produced multiple socialenvironmental tensions within Indigenous communities and leadership. The meaning of Indigenous identity itself has continued to evolve within the dialectic with outsiders over resources, their usage, and ownership. Focus on the critical interactions between Indigenous people, communities, businesses, and states spearheading extractivism, as well as the counterwork they entail, may reveal a more nuanced, yet detailed and accurate picture of current socio-environmental tensions throughout South America.

Chapters in this book help explain the role that indigeneity is playing increasingly as a moral anchor and what Fabricant and Postero refer to as the 'ethical substance' (Povinelli 2011) regarding extraction and use of natural resources. They argue that indigeneity serves as 'ethical substance', a central site of moral reflection and conduct in a certain era or social world. While this case specifically explains Native opposition to plans by the MAS government in Bolivia to build a highway through their lowland Indigenous lands and territories, the example helps to analyse analogous Native responses to extractivism throughout the world.

Furthermore, if some Andean Native people have, at times, benefited economically from the sale of their resources, and if other communities have likewise suffered untold environmental damage, to what degree will indigeneity function as an anchor for moral reflection and conduct in a 
world of rapidly changing values? Can Western people, states, and businesses learn about the environment and our global future from Indigenous perspectives and efforts to defend the resources and lands on which their lives depend? How much does 'performance' and display of identity remain a central venue serving as a catalyst for moral reflection about indigeneity and the articulation of alternative social worlds? Resistance to extractivism, as well as Indigenous support for these policies in cases, have evolved to reflect and shape Indigenous identity in different ways. What are the costs and benefits to claiming that Native nomenclature in future years? What costs will extractivism bring to the environment and Indigenous communities going forward?

This new book and its insightful anthropological studies provide answers to some of these questions and are a welcome addition to the study of recent Indigenous experiences. Even as the world and its people move into an unprecedented future of climate change, these studies help illuminate the path ahead. Together these chapters shed light on these cultural, political, and environmental questions by focusing on specific cases of the dialectical relationships between Indigenous people, their ongoing relations to their resources, and growing extractivism in South America.

Boone, NC, USA

René Harder Horst

\section{Notes}

1. McCreery, David, 1990. State Power, Indigenous Communities, and Land in Nineteenth-Century Guatemala, 1820-1920. In Guatemalan Indians and the State, 1540 to 1988 , ed. Carol A. Smith. Austin: University of Texas Press. Page 107.

2. Grandin, Greg, 2000. The Blood of Guatemala, A History of Race and Nation. Durham, NC: Duke University Press. Page 111.

3. Taussig, Michael, 1984. Culture of Terror-Space of Death: Roger Casement's Putumayo Report and the Explanation of Torture. Comparative Studies 26(3): 467-497. Page 474.

4. Barrett, Rafael, 1978. El Dolor Paraguayo. Caracas: Biblioteca Ayacucho, pages $125-129$.

5. Knight, Alan, 1986. The Mexican Revolution, Vol. 1. Lincoln and London: University of Nebraska Press. Pages 112, 119-120.

6. Crow, Joanna, 2010. Embattled Identities in Postcolonial Chile, Race Region, and Nation during the War of the Pacific, 1879-1884. In Military 
Struggle and Identity Formation in Latin America, Race Nation, and Community During the Liberal Period, eds. René Horst and Nicola Foote. Gainesville: University Press of Florida. Pages 254-258.

7. See, for example, the article by anthropologist Warren, Kay B., 1992, Transforming Memories and Histories: the Meanings of Ethnic Resurgence for Mayan Indians, In Stepan, New Interpretive Essays, New York and Oxford: Oxford U. Press. For more on these theoretical approaches to indigeneity, see Warren, Kay B., 1998, Indigenous Movements and their Critics. Pan-Maya Activism in Guatemala, Princeton, Princeton University Press. Another insightful book on these issues is Warren and Jean E. Jackson, 2002, Indigenous Movements, Self-Representation and the State in Latin America, Austin, University of Texas Press.

\section{REFERENCE}

Povinelli, Elizabeth. 2011. Economies of Abandonment: Social Belonging and Endurance in Late Liberalism. Durham: Duke University Press. 


\section{ACKNOWLEDGEMENTS}

We would like to thank the Norwegian Latin America Research Network (NorLarNet), and the project 'De-Naturalising Difference' at the Department of Social Anthropology, University of Bergen, for providing funding for the workshop 'Indigenous cosmologies and politics of extractivism in Latin America: Ethnographic approaches'. This workshop was held in June 2016 at the University of Bergen and became the point of departure for this book. We would also like to thank the University of Bergen for providing funding for travel through the Strategic Programme for International Cooperation (SPIRE). We specially thank Oda Eiken who assisted in organising the workshop.

We greatly appreciated all of the insightful contributions of participants at the workshop in 2016. Since then, we have received constructive comments and suggestions to our book, especially from Nancy Postero, Carlos Fausto, Mario Blaser, and María Guzmán-Gallegos, among others. We are grateful also to the editors of this series, Synnøve Bendixsen and Edvard Hviding, for their useful advice and suggestions and to Kyra Saniewski and Mary Al-Sayed at Palgrave for their valuable advice. We would especially like to thank Katharine Wheeler for assistance with language editing and proofreading in an important phase of our work with this book and to Isabelle Hugøy for all sorts of invaluable assistance along the way. A special thanks to all the authors who have contributed to our book and have taken part in this journey with us - some already since the workshop and others who have joined us along the way. Thank you! Now that the book is to be published, we would like to also express our 
appreciation that the University of Bergen has provided funding to make this book accessible to a broader audience as Open Access.

Juan Javier Rivera Andía would like to thank the following institutions for supporting his work, particularly those tasks related to this volume: the Agència de Gestió d'Ajuts Universitaris i de Recerca of the Government of Catalonia, the Estudio antropológico comparativo de las nociones de ser humano (HUMANT) project (HAR2013-40445-P) of the Antropologia $i$ història de la construcció de les identitats socials $i$ politiques (AHCISP) research group of the Universitat Autònoma de Barcelona, the SPIRE programme of the University of Bergen, and last but not least the Marie Curie Alumni Association's grants programme.

Cecilie Vindal Ødegaard extends her gratitude for research funding from the Norwegian Research Council provided for different research projects in recent years, among them the funding provided through the research project 'Contested power in Latin America', headed by John A. McNeish. A special thanks to the Norwegian Research Council for Project Establishment Support also to the further development of research ideas connected to the project titled 'Enactments of property ownership in times of climate change'.

Finally, we would like to mention that Chap. 10, by Nicole Fabricant and Nancy Postero, is a slightly revised version of a piece with the same title previously published in Anthropological Quarterly. We thank the journal for permission to reprint it here.

Bergen and Brussels

August 2018

Cecilie Vindal Ødegaard Juan Javier Rivera Andía 


\section{Contents}

1 Introduction: Indigenous Peoples, Extractivism, and Turbulences in South America

Juan Javier Rivera Andía and Cecilie Vindal Ødegaard

Part I Flows, Wealth, and Access

2 Controlling Abandoned Oil Installations: Ruination and Ownership in Northern Peruvian Amazonia

María A. Guzmán-Gallegos

3 Extractive Pluralities: The Intersection of Oil Wealth and Informal Gold Mining in Venezuelan Amazonia Amy Penfield

4 In the Spirit of Oil: Unintended Flows and Leaky Lives in Northeastern Ecuador

Stine Krøijer

5 Translating Wealth in a Globalised Extractivist Economy: Contrabandistas and Accumulation by Diversion

Cecilie Vindal Ødegaard 
Part II Extractivism, Land, Ownerships

6 Water as Resource and Being: Water Extractivism and Life Projects in Peru

Astrid B. Stensrud

7 The Silent 'Cosmopolitics' of Artefacts: Spectral Extractivism, Ownership and 'Obedient' Things in Cañaris (Peru)

Juan Javier Rivera Andía

8 Carbon and Biodiversity Conservation as Resource Extraction: Enacting REDD+ Across Cultures of Ownership in Amazonia

Marc Brightman

Part III Indigeneity, Activism, and the Politics of Nature

9 Stories of Resistance: Translating Nature, Indigeneity, and Place in Mining Activism

Fabiana Li and Adriana Paola Paredes Peñafiel

10 Performing Indigeneity in Bolivia: The Struggle Over the TIPNIS

Nicole Fabricant and Nancy Postero 


\section{Notes on Contributors}

Marc Brightman is Lecturer in Anthropology at University College London. His most recent books include The Imbalance of Power: Leadership, Masculinity and Wealth in Amazonia (2016), Ownership and Nurture: Studies in Native Amazonian Property Relations (with Carlos Fausto and Vanessa Grotti, 2016), and The Anthropology of Sustainability: Beyond Development and Progress (with Jerome Lewis, Palgrave 2017).

Nicole Fabricant is Associate Professor at Towson University. Her research addresses the cultural politics of resource wars in Latin America, and she is working on a research project in El Alto, Bolivia, which examines the localised experiences and the organisational tactics related to mobilisation around water scarcity.

María A. Guzmán-Gallegos is Postdoctoral Fellow at the University of Oslo and has done fieldwork in Kichwa communities in Ecuadorian and Peruvian Amazonia. Her research has focused on personhood and gender, Amerindian conceptualisations of nature and society, interethnic relations, indigenous movements, and socio-environmental conflict related to extraction.

René Harder Horst is Professor of History at the Appalachian State University in North Carolina. He is author of The Stroessner Regime and Indigenous Resistance in Paraguay, the forthcoming textbook A History of Indigenous Latin America, and co-editor of Military Struggle and Identity Formation in Latin America: Race, Nation, and Community During the Liberal Period. 
Stine Krøijer is Assistant Professor at the University of Copenhagen and has several publications on the impact of climate change on social life, conflicts around extractive industries, and the politics of nature and development in the Ecuadorian Amazonia. She has also conducted research among European activists.

Fabiana $\mathbf{L i}$ is Associate Professor of Anthropology at the University of Manitoba, Canada. She is the author of Unearthing Conflict: Corporate Mining, Activism, and Expertise in Peru (2015), recently translated into Spanish and published in Peru.

Adriana Paola Paredes Peñafiel holds a PhD in Rural Development from the Universidade Federal do Rio Grande do Sul (2016). She is a Lecturer at the Universidade Federal do Rio Grande. Her research deals with mining, peasantry, and ontologies. She has also worked in rural development projects among small farmers in Brazil.

Amy Penfield holds a PhD in Anthropology from the London School of Economics. Her work explores material and ethical value in Venezuelan Amazonia, with particular attention to the use of manufactured items in the contemporary political context. Her new research investigates smallscale mining in the lowland regions of Peru and how gold prospectors envisage their place within the global economy.

Nancy Postero is Associate Professor of Anthropology at the University of California, San Diego. She works at the intersection of politics, race, and political economy. She is the author of Now We Are Citizens: Indigenous Politics in Post-Multicultural Bolivia (2007). Her new book is The Indigenous State: Race, Politics, and Performance in Plurinational Bolivia (2017).

Juan Javier Rivera Andía is an anthropologist born in a mining camp near La Oroya (Peru). He has carried out research at various international research centres in Europe, and has written widely on contemporary Andean Quechua indigenous worlds. His most recent books and compilations are Non-Humans in Amerindian South America (2018) and Cañaris. Etnografias y documentos de la sierra norte del Perú(2018).

Astrid B. Stensrud is Postdoctoral Fellow at the Department of Social Anthropology, University of Oslo. Her research interests include humanenvironmental relations, micro-entrepreneurship, animistic practices, and water in the Peruvian Andes. She has published various articles and book chapters on climate change, water politics, and world-making practices. 
Cecilie Vindal Ødegaard is Associate Professor of Social Anthropology, University of Bergen, and author of the monograph Mobility, Markets and Indigenous Socialities: Contemporary Migration in the Peruvian Andes (2010). Her research interests include informal economies, labour, gender, extractivism, and conceptualisations of nature in the Peruvian Andesissues on which she has published widely. 


\section{LisT OF Figures}

Fig. 6.1 A pago is prepared nearby a spring, with herbs, coca leaves, llama fat, and a dried star fish

Fig. 7.1 The Iglisya of Incahuasi

Fig. 9.1 María singing, São Lourenço do Sul, Brazil. (Photograph: Sedufsm, 2017) 


\section{Introduction: Indigenous Peoples, Extractivism, and Turbulences in South America}

\section{Juan Javier Rivera Andia and Cecilie Vindal Ødegaard}

The edited volume we present here examines indigenous life-making projects in the encounter with extractivist politics and operations. It includes ethnographic studies of Amerindian strategies performed to face the 'slow violence' (Nixon 2013) or the turbulences (Bessire 2014) undergone by human-nonhuman relationships in contexts and sites of extractivism in South America. We explore how alternative politics of nature are negotiated and mediated in arenas where the extractive industries increasingly privatise and commodify 'the common good' (Blaser and de la Cadena 2017). With attention to the continuous and asymmetrical confrontations and entanglements of different politics of nature, we examine the various ways in which extractivism actualises questions of ontological difference. We explore how indigeneity is represented, performed, and recreated-by

\footnotetext{
J. J. Rivera Andía $(\bowtie)$

Universitat Autònoma de Barcelona, Barcelona, Spain

C. Vindal Ødegaard

University of Bergen, Bergen, Norway

e-mail: cecilie.odegaard@uib.no

(C) The Author(s) 2019

C. Vindal Ødegaard, J. J. Rivera Andía (eds.), Indigenous Life

Projects and Extractivism, Approaches to Social Inequality and

Difference, https://doi.org/10.1007/978-3-319-93435-8_1
} 
indigenous as well as national and international actors-in struggles over extractivist politics and endeavours. As we address these issues, we highlight our contributors' detailed ethnographic approaches. Indeed, the chapters we have assembled are grounded in the long-standing fieldwork experiences of their respective authors. We look beyond the boundaries of popular and academically fixed regions, as, for instance, the Andes and Amazonia, by including chapters from various countries and geographical regions of South America whose differences are usually taken for granted rather than explored and debated. Although study of resource extractivism in the region is growing, it tends to focus on wider national and international politics, often at the cost of the micropolitics and perspectives of indigenous groups. In this introduction to the volume, we provide a framework for the main preoccupations and perspectives addressed in the different chapters and their ethnographic insights and arguments.

\section{South American Turbulences}

Rights of the earth (in Bolivia) or rights of nature (in Ecuador) have become part of national agendas and policies in South America, a region that includes many of the world's few remaining wilderness areas. Are we witnessing 'a movement for the right to exist differently' (Escobar 2016: 26)? Instead of allowing these movements to be swallowed by modern politics (de la Cadena 2014), indigenous life-making projects 1 - in a context considered both as potentially a 'massive producer of sustainable power' (Howe 2015: 232) and as threatening for environmental activists-are invoking nonhuman beings linked to the landscape (mountains, water, and soil) as actors in the political arena. In the Andes, for instance, the 'runakuna [indigenous people of Cuzco] engage in political practices that...the state cannot recognize...because...it would require its transformation, even its undoing' (de la Cadena 2015: 14). These invocations, which place local populations in opposition to states and multinationals, reveal divergences of basic ontological dynamics concerning what the world is made of, what is valuable within or about it, and why.

This search for possibilities to think otherwise has become particularly salient in a situation of ecologic crisis and the discourse on the Anthropocene. Considered the consequences of a particular practice of worlding, in which the status of the planet becomes an object of human design, the notion of Anthropocene-the term most commonly used to 'remark that humans are now the dominant environmental force on the Earth' (Caro et al. 2012: 185) —'scale up our imagination of the human' 
(Chakrabarty 2009: 206). Some authors consider also that this term, although problematic and contested (Haraway et al. 2016), has made the general public more receptive to alternative life projects and the possibility of conscious redesign of the planet (Blaser et al. 2004; Carstensen 2014; Shellenberger and Nordhaus 2011; Kawa 2016). For many, the formulation of indigenous alternatives to extractivist capitalism appears acute and has gained renewed attention in scholarly debates.

I am convinced that in the somber decades to come, the end of the world "as we know it" is a distinct possibility. And when this time comes... we will have a lot to learn from people whose world has already ended a long time ago — think of... the Amerindians who, nonetheless, have managed to abide, and learned to live in a world which is no longer their world "as they knew it". We soon will be all Amerindians. Anthropology would be thus in a position to furnish the new metaphysics of the "Anthropocene" (Viveiros de Castro 2015b: 16).

The inclusion of nonhuman entities in several contexts of South American political life appears to get new impulse with what we often refer to in anthropology as the turn to ontology. While ontology includes a variety of different perspectives beyond the scope of this introduction, we address only one of its central features: the attempt to rethink the relationship between humans and the material world in an effort to throw new light on modernist assumptions underlying Euro-American thinking, as well as anthropological theory and methodologies (Holbraad and Pedersen 2017). A central theme for several contributors to this attempt (some of whom work in South American Amerindian regions) (Viveiros de Castro 1992; de la Cadena 2010) is the problematisation of 'modern', Western dualisms between matter and thought, nature and culture, signifier and signified, and object and subject-an ontology of dualisms which are considered inherent to capitalism (e.g., Tsing 2015). According to Holbraad (2012), for instance, these dualisms are problematic not only because they 'are not shared worldwide' but also because they are implied in our own analytical models and ways of representing the other. Holbraad seeks to go beyond the trope of representation by suggesting the 'use [of] ethnography to transform analysis' (2012: xviii). He proposes a shift in anthropological analysis from epistemic orientations to ontological transformations by drawing on the way in which Cuban (Ifá) divination practices seek to transform the world (rather than represent it) by interfering with the very meaning of truth 
(2012: xviii): 'Convention relies on the assumption that the realm of symbols and the realm of things for which they stand are opposedculture to nature, representation to world' (2012: 44). According to Holbraad, the nature-culture dichotomy-implied in the distinction between signified (matter) and signifier (thought)—serves to reinforce the presumption that both anthropologists and the people they study are in the business of representation and not invention (2012: 46). From this perspective, the approach anthropologists have conventionally taken in issues of reality and metaphor, signifier and signified raises fundamental questions about their approach to difference and the risk of reducing it to a question of (or response to) something else, such as inequality or socio-economic processes (see, e.g., Ødegaard 2016). The tendency in some branches of anthropology has, for instance, been to reduce certain ritual and magical practices or 'beliefs' (e.g., attacks by blood-consuming killers called kharisiris in the Andes) to a manifestation of local populations' experience of inequality or loss and fear connected to the intrusive strangers of modernity (cf.: Ansión 1987; Portocarrero 1991). While such attacks cannot be separated from the (post)colonial encounter, their understanding as mere representations of something else-and apparently more real-may limit further exploration of ontological dynamics and underpinnings (Ødegaard 2016: 66; see also Penfield and Stensrud, this volume). '[S] uspended between the radical contingencies of fieldwork and the radical reflexivity of the anthropologist' (Pedersen in Boellstorff 2016: 400), we may thus be inclined to undermine ethnographic specificities and overlook ways of being or forms of life that depart from hegemonic Euro-American conventions (and which otherwise might have informed our development of analytical alternatives).

Other main exponents of the so-called ontological turn have argued for the importance of taking the radical alterity of conceptual universes seriously, giving focus to differences between worlds or ways of being rather than epistemological worldviews and ways of knowing (Viveiros de Castro 2004b; de la Cadena 2010; Hage 2012). Suggesting the term multinaturalism, Viveiros de Castro (1992, 1999, 2015a) problematises the dichotomy, present in standard Euro-American discourses on multiculturalism, between nature (as given) and culture (as variable), because such notions reduce difference to a matter of social projections. He has also criticised anthropologists' concern with animism, in South America and elsewhere, as mainly a question of epistemology (see Bird-David 1999), arguing that 
such practices should not be understood only in terms of knowledge or representation of reality (although other anthropologists have replied 'that epistemology need not be derealization' [Boellstorff 2016: 397]). Viveiros de Castro (1999) has thus problematised the ways in which anthropologists often attempt to explain what he considers non-Western ontologies by deriving them from (or reducing them to) epistemology. Instead of 'this massive conversion of ontological questions to epistemological ones', which Viveiros de Castro terms the hallmark of modernist philosophy, he defines animism ${ }^{2}$ as an ontology 'concerned with being and not with how we come to know it' (1999: 79). Hence, animism, he postulates, is the social character of relations between humans and nonhumans where both are immersed in the same sociocosmic medium (1998: 473). By suggesting this approach, Viveiros de Castro seeks to avoid an understanding of animism in an Amazonian context as simply a projection of differences and qualities of the human world onto the nonhuman world (1998: 474). As noted by de la Cadena (2010), this aspect of Viveiros de Castro's argument is relevant in the Andean context where human relations with mountains and other earth-beings cannot necessarily be understood as a 'cultural interpretation' of 'nature' (de la Cadena 2010: 365; 2014). These practices and relationships constitute worlds that should not be reduced to a matter of social projections nor can they be conceptualised as a fixed set of features: "one is never animist "in general", only in terms of assemblages that generate metamorphic transformation in our capacity to affect and be affected' (Stengers 2012).

Many authors working on different ethnographic regions around the world have, if not necessarily or directly criticised the turn to ontology, at least pointed out that 'we don't know what [the ontological turn] means yet' (Kelly 2014: 264). Taking into account its current relevance in mainstream anthropology, ontology has also been viewed as a sort of buzzword (Pedersen 2014; Halbmayer 2012: 11). Popularised at least since the publication of Thinking through Things (Henare et al. 2007), the turn is seen today as not 'particularly new anymore, let alone [lasting] forever' (Pedersen 2014). The coincidence of the turn to ontology with the contemporary inclusion of nonhuman entities in political life in South America indicates the interconnectedness of sociopolitical processes and academic endeavour. We evoke the question of ontology, ${ }^{3}$ considering its implications and effects, in an attempt to fully appreciate indigenous terms and experiences. 


\section{On Turns and Doubts: Critique and Politics}

The turn to ontology in anthropology has also come under harsh criticism (e.g., Turner 2009; Ramos 2012; Vigh and Sausdal 2014; Bessire and Bond 2014b) and has created divisions through heated debates with sometimes dramatic opposition (see Reed 2016). Some argue that the 'radicalising unfamiliarity [or] alterity' (Alberti et al. 2011: 906) of the turn to ontology, which seems to require 'the radical incommensurability of modern and non-modern worlds' (Bessire and Bond 2014a: 442) as an analytical point of departure, might lend itself to potentially dangerous political constructions of otherness that could be used against marginalised groups (Vigh and Sausdal 2014; Rival 2012a, b: 138; Carstensen 2014: 26; Rivera Andía 2015; Todd 2016: 10; Cepek 2016; see also Krøijer, this volume). Some of the more moderate critics of various aspects and implications of the ontological turn focus on flaws regarding hybridisations, the possible internal differences within ontologies, as well as the significance of its classifications (Ingold 2000; Halbmayer 2012; Pazos 2006, 2007; Willerslev 2007; Kohn 2013; Scott 2013; Piette 2012; Descola 2014a, c: 298; Neurath 2015: 59-60). Others ask whether proponents of the turn to ontology are taking indigenous animism too literally or dealing with abstractions that hardly apply to ethnography. In fact, some critics have equated the turn to ontology with a kind of dogma, suggesting that its proponents both advocate a sort of faith and reduce social and cultural life and relations to nothing more than idealised types (Oyuela-Caycedo 2014; Scott 2013; Killick 2015; Franklin 2017; Willerslev 2013, Keane 2013; Fischer 2014; Ramos 2012; Course 2010). Lucas Bessire and David Bond (2014a: 444) suggest that the restriction of 'indigenous ontological legitimacy' to the terms of an 'orthodox dialectic of Otherness' might in fact erase those individuals who do not correspond to the particular mythology in which the dialectic is exclusively grounded.

Other authors raise doubts about the alleged indifference of the ontological turn's proponents to current indigenous political concerns and adversities (Ramos 2012: 483-484). Following previous critiques of the representation of Western modern thought as an integral, homogeneous system of abstract-type concepts (Turner 2009: 16), Bessire and Bond have questioned the conditions under which ontologies are 'made amenable to ethnographic analysis' (Bessire and Bond 2014a: 443; see also Heywood 2012: 146; Gordillo 2014: 185-190). In his review of Holbraad's study, Evan Killick points out that 
[T]he complex ideas, practices and social processes of everyday life are overlooked in the intellectual pursuit of radical alterity... . [This] proposed methodological emphasis on alterity ... [has] the danger both of overinterpreting, or perhaps over-intellectualising, alternative views and practices... . [The] philosophical ideas become an end in themselves, not linked to raising further ethnographic questions or elucidating other social and cultural phenomenon but rather held up as precious jewels to be admired in isolation (Killick 2014).

In a similar vein, Bessire denounces the turn to ontology as a 'mystifying ethnographic project' based on the 'active omission of the conditions and relationships' that allow anthropological knowledge (Bessire 2014: 39). At the same time, he advocates paying more attention to the influence of anthropological knowledge on Amerindian destinies and the unequal forces that such knowledge can exert against indigenous peoples (Bessire 2014: 26). Furthermore, this ethnographer notes that the emphasis on ontology 'standardizes multiplicity and fetishizes alterity' (Bessire and Bond 2014a: 449; see also Rivera Andía 2015; Wardle and Schaffner 2017: 21; Todd 2016: 17; Cepek 2016). A few years earlier, Ramos suggested that 'to attribute so much uniformity to native thinking... is to flatten down (if not deny) [native] inventiveness and aesthetic sophistication and to ignore... specific historical trajectories' (Ramos 2012: 483). Finally, Candea recognises that the question of interlocution has not been 'conclusively addressed' in the ontologically inflected anthropology: 'whom, precisely, is one "taking seriously," and what might a disagreement or response from them look like?' (Candea 2014). These authors remind us of the need to explore "both the possibility of an "other" politics and the possibility of there being other than politics' (ibid.) in the context of the urgent problems facing indigenous peoples (e.g., Bessire and Bond 2014c).

In answer to the criticisms, two of the main proponents of the ontological turn have both emphasised the political dimension of their theoretical proposals. Descola asserts that ontology enhances the anthropological study of politics when it comes to indigenous movements that see nonhumans as political subjects in their own collective (collectif) (Descola 2014b: 348):

[I]t is precisely our attempt to do away with those Eurocentric categories [class, race, gender] and with the colonial project of sucking into our own cosmology peoples who, having lost their lands, their dignity, and their work-force, face the added ignominy of having to translate their ways of life into our own way of life and of being grateful to us for providing them the tools to do so (Descola 2014d: 436). 
Also at stake is anthropology's relation to both the domain of politics per se and the spectrum of possible analyses of the enactment and constitution of politics (see Bertelsen and Bendixsen 2016: 4-5). According to Viveiros de Castro (2015b), ontological questions are political questions insofar as they come into existence only in the context of friction and divergence between concepts, practices, and experiences.

For authors like Gassan Hage (2012), the future of a critical anthropology is one that has the potential to encourage as well as generate different forms of politics, relying precisely on a recognition of ontologically differentiated alterity and difference. Similarly, according to de la Cadena (2014), an ontologically informed anthropology contains the possibility to unfold the situated conditions of modern politics and a potential to unsettle its hegemony. Politics in the modern era, de la Cadena argues, is based on a distinction between humanity and nature, where the representation of nature in political life requires science. For centuries, indigenous people have been excluded from modern politics, being considered too close to nature and incapable of modernity. In this view, the status of indigenous people is intimately connected to the notion of modern politics and the nature-culture dichotomy, which undergirds the long-standing exclusion of indigenous people from politics. With increasing protests against extractive industries in South America in recent years, where nonhuman beings are actualised in political life, there is an unsettling of these long-established oppositions related to the nature-culture dichotomy.

An issue that has caught the attention of social scientists relatively recently is the way in which the ideologies and worldings (sometimes called naturalism) that accompany the industrial extraction of what is commonly denominated natural resources coexist with an alternative politics of nature. Referring to the politicisation of landscape and recent years' actualisation of earth-beings in protests and political life (de la Cadena 2010), this notion pinpoints the inclusion of nonhuman entities in the sphere of politics. Central to this alternative politics of nature are indigenous ways of cohabiting with an active, and living landscape, which is considered not as an inert object for humans to own, dispose of, or exploit but filled with nonhuman persons with whom one can or even must relate. Several scholars have recently taken an interest in how the inclusion of nonhuman entities in political life may potentially disrupt (and multiply) the dichotomies on which the understanding of politics is built (i.e., nature-culture, object-subject, science-politics) (Stengers 2012; Course 2010; Latour 2005, 2014; Law and Lien 2012). Interestingly, such a 
capacity to redefine the sensible world as an instrument of struggle is growing in significance far beyond the local in a period of history when the neoliberal paradigm is gaining ground as a mode of governance accommodating for market liberalisation (along with the introduction of new labour laws that promote low-term outsourcing, the privatisation of national services, and the criminalisation of poverty) ( $\mathrm{Li} 2015: 73)$. What is the scope of this mobilisation around entities of the landscape? As is widely recognised, the inclusion of indigenous world- and life-making projects and of nonhuman entities in the sphere of politics provide an idiom for action, an imaginary for critique, and the formulation of political alternatives. It has also turned into a resource for both protest movements and constitutions in contemporary South America, as well as for the (again) Euro-American imagination-including academic and anthropological thinking. While, historically, South American nation-state leaders and authorities have predominantly defined the indigenous as an unproductive other, as incompatible with prevailing notions of modernity and progress, researchers and activists are currently revitalising the emergent life-making projects of indigenous people as a source of critique and in the formulation of utopian futures (Rivera Andía 2005a). In the following pages, we discuss the possibilities and issues related to these tendencies.

Central for many proponents of ontological approaches to anthropology-also as regards anthropology's political potential -is the attempt to reinvent it as a comparative discipline. Following this line of reasoning, one of anthropology's central aims should be to draw on different ways of being in the world in order to rethink Euro-American categories. Tim Ingold, however, has criticised what he considers the deep asymmetry of some of these comparative projects. At the end of the day, he argues, this mode of comparison still places the anthropologist in the role of emancipated observer, free to move around in the domain of human diversity:

[T] he observer has no place, he is nowhere, he does not recognise any ontology as his own... [H] affirms that he is an ontological pluralist. One might say that he observes the world from a sort of ontological paradise from which we are all excluded, we who are imprisoned by our respective philosophies of being... . [F]rom his position of transcendental observer, he could thus affirm that there are different manners of composing a unique world. But this transcendental posture is in fact one of the bases of what he calls naturalist ontology... . [W] hatever he might say, he adopts as a neutral position a certain ontology: naturalism (Ingold in Descola and Ingold 2014: 54). ${ }^{4}$ 
Along similar lines, other scholars, such as Severin Fowles, have argued
that

[O] ur modernist ontology is inseparable from what we might call the exceptional position of nonposition. Whatever the world is, there must always be some position of nonposition outside it for the Western liberal subject to occupy, as reason stands apart from emotion, mind from body, referee from players, scientist from experiments, anthropologist from natives. In this sense, there is nothing more profoundly modern than the effort to step outside modernity. And this is precisely what the advocates of the ontological turn claim to have accomplished twice over: first by standing in the position of nonposition vis-à-vis other people's worlds and second by standing in the position of nonposition vis$\grave{a}$-vis the plurality of worlds itself (Fowles in Alberti et al. 2011: 907).

So how do we 'account for ontological encounters when any account presupposes an ontological grounding?' (Blaser 2009: 18). Is an anthropologist actually a 'masked moderniser who, under cover of pluralism, in fact, restores anthropological science's guiding function and therefore reinforces the Western in its intellectual imperialism'5 (Descola 2014b: 116)? The answers to these critiques could be seen as entailing a sort of retreat from the idea of a 'big theory' (ibid.) or 'a metaphysical issue best left to philosophers' (Holbraad in Alberti et al. 2011: 908). As we return to below, some proponents of the ontological turn in anthropology have indeed reacted by putting their strongest efforts in a rethinking of anthropology's methodological and comparative devices.

The edited volume we present here seeks to cast light on these debates by providing ethnographic studies of those world- and life-making projects that are currently being formulated by South American indigenous actors in response to ongoing politics of extractivism. Several issues arise when identifying lessons which can be learnt from indigenous positions in the local extractivist contexts of global capitalism. For instance, is it possible to raise this question about 'lessons learnt' in the first place, without jeopardising indigenous peoples and reproducing a notion of the noble savage? Do we thus risk encapsulating people within a constricted terrain of the permitted Indian or into a fetishised radical difference in which some hierarchically ranked world-making projects count more than others? While raising these questions, we do not try to make a particular methodological statement in this introduction, inasmuch as we do not intend to sharply 
demarcate the position or theoretical lines of contrast among the arguments summarised above or to discuss in detail the adequacy of any of them. We aim, rather, to modestly situate some of the still-evolving issues at stake.

\section{To Think Otherwise in Amerindian Extractivist Contexts: Towards an Engaged Ontography}

Both critics and proponents of the use of the term ontology could probably agree that there is still much to be learnt about, first, how indigenous groups detect and use particular properties of their environments and, second, how they change this environment 'by weaving with it and between themselves' diverse kinds of relations (Descola 2014c: 273). Subsequently, studies that tend to restrict the ontological turn to a reasonable and productive methodology (for instance, Holbraad's 'ontography') seem less affected by the strong criticisms of the philosophical or metaphysical premises reviewed above (Holbraad 2009, 2014; see Wardle and Schaffner 2017: 17-21). Pedersen, for example, considers the ontological turn as 'a strictly methodological proposal':

[The ontological turn] is the methodological injunction to keep this horizon perpetually open, including the question of what an object of ethnographic investigation might be and, therefore, how existing genres, concepts and theories have to be modulated the better to articulate it... . [T] he ontological turn is not concerned with the "really real" nature of the world... [It] is a methodological project that poses ontological questions in order to solve epistemological problems... . [E]pistemology in anthropology has to be about ontology too (Pedersen 2017: 229-230).

Stressing the turn to ontology as a 'commitment to recalibrate the level at which analysis takes place' (Course 2010: 248), Holbraad has characterised the turn as a radicalisation of three basic anthropological requirements: reflexivity, conceptualisation, and experimentation (Holbraad in Alberti et al. 2011). He insists on the rejection of any previous compromise concerning the types of phenomena that could constitute the focus of an ethnographic discipline and how anthropological concepts could be transformed in order to observe them. His radicalisation of reflexivity indeed gives conceptualisation a central place in the ontological turn, which aims to transform critical reflexivity 
into what he considers conceptual creativity (Holbraad 2014: 128-137). Consequently, Holbraad describes his ontographic approach as a 'break out of the circle of our conceptual repertoire' (2009: 433) using 'the extraordinary data to reconceptualize ordinary assumptions in extraordinary ways' (Holbraad 2009: 435; see also Lebner 2017: 225; Wardle and Schaffner 2017: 11):

[T]he task of conceptualization that any given set of animist phenomena may necessitate may certainly involve engaging with Western ontological revisions, but is most likely to require analytical labour that goes further than that (Holbraad 2009: 436).

\section{Further:}

[T]he turn to ontology in anthropology is not about offering some suitably improved and ontically fortified replacement for culture. Rather, it is about offering a better way to address just one of the questions "culture" was always supposed to absorb-namely, the analytical problem of how to make sense of things that seem to lack one (Holbraad in Alberti et al. 2011: 902).

This is what ultimately lies behind statements such as this from Viveiros de Castro: 'Anthropology's role, then, is not that of explaining the world of the other, but rather of multiplying our world' (2015b). In fact, there are various concordances between Holbraad's concept and Viveiros de Castro's proposals. The latter has written about what he calls 'speculative ontography' (2015a: 75) and declared that the most interesting thing in perspectivism is not that it illustrates an ethnographic phenomenon, but that it illustrates a methodological imperative for anthropological thinking: the need to be able to exert radical reconceptualisations (ibid.). The reflexivity similarly implied in Holbraad's ontography echoes the 'reversibility' pursued by the 'new anthropological epistemology' proposed by Corsín Jiménez and Willerslev (2007). It also resonates with Strathern's well-known proposal: 'It matters what ideas we use to think other ideas.' Some of her colleagues have expanded and updated the proposal to: 'It matters what worlds world worlds' (Haraway 2016: 35).

Throughout this volume, we are interested in emphasising the importance of ethnographic field studies for further theoretical development. We acknowledge that detailed research is necessary to understand the multiplicity of conceptual and practical relationships that humans establish with their environment. 
[It] tends to be ethnography, the actual words, actions and ideas of other people that generate alternative versions that are much more complex and novel than anything "we" can dream up (Killick 2014).

We seek to facilitate, in the South American context, the use of anthropological imagination and the forging of new concepts and approaches that could re-establish ethnography as 'the prime heuristic in anthropology' and return it to the foreground of current conceptual developments (HAU n.d.). We want to test this ethnographic engagement using a detailed empirical basis for arguments about the role of extractivism in the discontinuities or reproductions of indigenous worlds that is not beholden to the most recent theoretical developments.

\section{Extractivism, Enclosure, and Protests}

During the last few decades, there has been an ongoing extractivist boom in, but not limited to, South America. Following World Bank and International Monetary Fund prescriptions that, during the 1990s, encouraged the relaxation of conditions for foreign investors in the mineral sector of developing countries (Ballard and Banks 2003: 294), investments in mining explorations increased dramatically: 90 per cent worldwide, 400 per cent in Latin America, and 2000 per cent in South America. In Peru, mining activity now affects more than half of the 6000 peasant communities (Li 2015: 16). Extractivism epitomises the contemporary situation in many South American countries in several ways, raising issues of environmental degradation, sustainable development, resource sovereignty, and vulnerable (often indigenous) populations' position and options. During the last couple of decades, governments across the political spectrum throughout the region have relied increasingly on the extraction of natural resources, representing extraction and export as key to economic growth and progress (Arsel et al. 2016), while often tolerating cyanide-leaching technologies and offering minimal environmental regulation, low labour costs, as well as low tributary payments ( $\mathrm{Li} 2015$ : 81).

The current stronghold of the extractive industries in South America has been driven by the high commodity prices of the early twenty-first century, the global demand for energy and minerals, as well as technological changes in the mining industry itself (Bridge 2004; Li 2015; ChiassonLeBel 2016). High commodity prices, or the so-called commodity boom, in particular, are often blamed for fostering what Svampa (2013: 31-36) has 
called the 'commodity consensus': a tacit agreement by most Latin American governments, both left and right wing, made in the absence of real alternatives to the exploitation of internationally traded commodities (see also Chiasson-LeBel 2016: 1). As noted by Hasland and Heidrich (2016), the commodity boom reshaped the model of development throughout South America and elsewhere in the Global South. In some countries, these national policies have been dominated by foreign capital, while in other countries (i.e., Venezuela, Brazil, Bolivia, Ecuador) developments have taken shape as governments have increased taxes and royalties on the resource sector, foreign firms have been nationalised, and public spending on social and developmental goals has increased (ibid.; see also Gudynas 2011, 2018). While there are, thus, certainly national specificities characterising the role of extractive industries in South American countries, as well as different political and economic policies, the extraction of oil, gas, metals, and minerals shows continuities across different types of regimes over time and across space in the region (Bebbington and Bebbington 2012; Li 2015).

The latest commodity boom coincided with the Pink Tide in South America-the elective victories of progressive forces that in many countries changed policies and attitudes towards the extractive sectors. As the prices of metals, oil, and gas roughly tripled, several countries in the region followed in the footsteps set by Venezuela in 1998 and Brazil in 2002, some electing radical and others more moderate leftist presidents driving the 'progressive neo-extractivism'. High commodity prices helped the new political leaders push their political agenda: break with the dominance of the neoliberal development model and give the state a central role in extractive sectors and in programmes to tackle poverty and development. However, this new shape of the 'extractive imperative' (Arsel et al. 2016) went against these presidents' initial promises to respect the rights of indigenous communities, social movements, and the environment. In effect, civic concerns and demands concerning the expansion of mining, oil, and gas extraction produced a proliferation of conflicts, especially at the local level. According to the United Nations Environment Programme (UNEP), at least 40 per cent of inner conflicts of the last 60 years have, in one way or another, been linked to natural resources. Between January 2011 and October 2015, however, commodity prices fell dramatically, ${ }^{6}$ and, for a period, the price of hydrocarbons even returned to pre-boom levels (Arsel et al. 2016). Several countries with large extractive sectors entered a period of economic and fiscal crisis, 
particularly Venezuela. Among the available policy responses, Arsel et al. (2016) note, has been to further increase extraction in areas that invariably intrude on landscapes and territories on which indigenous and other marginalised communities depend (ibid.: 877-878).

Following these developments, researchers in the social sciences have once again made the extractive industries a central theme, often with a focus on the interconnectedness between extractivism and politics (Mitchell 2011; McNeish et al. 2015), as well as the social and environmental effects of extractivism and protests made in response. In effect, the notion of extractivism has become widely used to pinpoint the extractive industries as a defining feature of political and economic life. As a descriptive term, extractivism may refer to modes of accumulation based primarily on the removal of large quantities of 'raw' materials (especially of minerals and oil but including also farming, forestry, and fishing) which are either not processed or are processed but only to a very limited degree and which are extracted, in particular, for international markets (ChiassonLeBel 2016: 2; see also Acosta 2011, 2013; Vetlmeyer and Petras 2014; Matthes and Crncic 2012). While the term may serve primarily descriptive purposes referring to the extraction of 'natural resources', it is used also as an analytical term referring to particular developments in domestic and global economies. Indeed, the term was first developed as a critique of the development model adopted by many countries in the Global South (Bunker 1984) and shares some common ground with, for instance, dependency approaches to development, problematising the reliance of certain national economies on the extraction of raw materials for exports (whether minerals, hydrocarbons, fishing, or agricultural products). Hence the term has gained ground in scholarly attempts to take issue with the importance of primary resources for export among national economies, especially in the Global South, simultaneously including a focus on environmental concerns (see Gudynas 2011: 25-27; Chiasson-LeBel 2016: 2). More recently, the concept neo-extractivist economy has frequently been applied in critiques of Latin American governments associated with the Pink Tide that continued to rely on an extractivist economy. Neoextractivism, then, expresses the unfulfilled expectations that left-wing governments would radically change the development model to move away from a commodity export-led model (Chiasson-LeBel 2016: 2). As Chiasson-LeBel notes, and as Horst discusses in the preface to this volume, the situation depicted through these terms is far from new-not even within the energy sector-considering that petroleum, for example, has 
been a dominant product for the Venezuelan economy since the 1920s and for Ecuador since the 1970s.

While the term extractivism was originally developed in reference to the heavy reliance of nation-states on the extraction of raw materials, a few scholars have recently tried to broaden the term to include different forms, practices, and dimensions of value extraction from all areas of life, including social ties and practices of social cooperation (Gago 2015). The extractivist economy in this sense epitomises particular dimensions and developments of contemporary global capitalism, especially those related to the commodification of new areas of life (i.e., in the form of big data, carbon markets, social cooperation, cultural identities, and imageries, etc.). We can view these various forms of commodification as both a continual expansion of sources for value accumulation and-the dominant form of accumulation by which elite power is restored-the dispossession of some parts of the population (Harvey 2007). Such a broad understanding of extractivism may draw attention to different dimensions of how capitalist projects extract value from a range of different forms and areas of life not previously part of capitalist commodification and accumulation, revealing how extractivist dynamics may embrace and affect all aspects of life (see, e.g., Krøijer, Brightman, Penfield, and Ødegaard, this volume). In the context of South America, these less conventional dynamics of extractivism are made particularly evident through green finance as well as carbon and biodiversity accounting in and through global carbon market programmes. Our concern with extractivism in this edited volume is not limited to the extraction of minerals, metals, or fossil fuels but includes issues of forests (Marc Brightman's chapter) or water (Astrid Bredholt Stensrud's chapter) and even issues related to the imminent but still spectral appearance of extractive projects (Juan Javier Rivera Andía's chapter). Therefore, we seek to engage the issue of extractivism and extractions of value in a broad sense. ${ }^{7}$

The extraction of primary materials in South America has affected, most visibly and dramatically, vulnerable populations, such as rural communities and indigenous groups. The resulting protests have often been motivated by concerns with environmental effects in local communities, a common disregard of laws about prior consultation, ${ }^{8}$ changes of landscape and land use, limited employment opportunities for local populations, ${ }^{9}$ and land grabs. Scholars have tried to pinpoint the challenges that the extractive industry may pose for local populations with the notion of enclosure, drawing on Marx by pointing to the enclosure of the commons 
and the separation of peasants from the land. According to Bridge, enclosure and exclusion are central to the creation of value in the extractive sector, in many cases instigated through the extension of state-granted concessions to private companies or to state-corporate consortiums (2008: $415)$. He argues that the often nonrenewable character of extraction may even imply that enclosure is a primary competitive logic in extractive industries, a prerequisite for which is the existence of vulnerable populations who have no legal, or otherwise ambiguous, ownership of land. Along similar lines, and seeking to understand the relations between enclosure, commodification, and struggle in the extractive industries, Bebbington and Bury (2014) discuss the accelerated rate of the extractive industry's recent expansion in South America, arguing that several countries in the region are currently undergoing a process of increasingly extensive enclosure. They note that enclosure is indeed central to the commodification of various parts of the landscape, and that it lays the basis for new rounds of landscape transformation as, for example, businesses seek to gain access to these commodities (2014: 11).

Landscape transformations as a result of the operations of extractive industries also create an important backdrop for the recent politicisation of nature. In recent years, mega-mining projects and the use of new technologies in the extractive industries have particularly broadened the extent of this landscape transformation (see Li 2015), sometimes resulting in the destruction of whole mountains, pasturelands, and water sources. As Li (2015) discusses in her study of mining in Peru, mining projects may transform people's relations of access to a wide range of resources. In the Andean context, recent forms of extractivism stand in contrast to previous, more low-tech and labour-intensive forms, and the practices by which locally based miners would give offerings (of food, alcohol, coca) to both appease the powerful earth-beings in exchange for the removal of mineral wealth and secure their own safety (see Li 2015; Harris 2000; Nash 1979). The recent mining landscape transformations exacerbate the disruption of forms of life and ways of living, and, as Li shows, have the potential to disturb relationships between people and an agentive and living landscape, sometimes through specific devices, such as buildings (see Juan Javier Rivera Andía, this volume). Li asks (2015: 75): 'How, then, does one argue with an evolutionist logic in which mining is portrayed as the inevitable road to progress?' Regarding the environmental conflicts of recent years, one of Li's central points concerns mountains. Mountains in such conflicts are not simply a landform or a resource nor a matter of differing 
perceptions among the actors involved in the controversy. Rather, protesters have mobilised elements that are usually absent from public debate: Apus, usually described as spirits of the mountains in the Andes. Through protests, apus have been brought into the sphere of national politics and become entities with which corporations and the state must contend (ibid.: 110-111; see also Harvey and Knox 2015). On the one hand, some scholars have criticised this approach for taking too seriously entities that are actually much less fixed and respected than created as a relatable fact in encounters with activism and protests (Cepek 2016; see also Krøijer, this volume). On the other hand, other authors have proposed that this inclusion of apus in politics can be considered the enactment of ontological politics of different worlds. For instance, and as previously noted, Blaser (2009) and de la Cadena (2010) have emphasised that contemporary environmental struggles in South America are also conflicts over different realities or worlds. According to the latter, this implies that:

no separation exists between Ausangate the Word and Ausangate the earthbeing; no "meaning" mediates between the name and the being. [Mountain] Ausangate is, period. Not a belief but a presence enacted through everyday practices (de la Cadena 2015: 25-26).

The conflicts do not simply concern competing interpretations of naturescholars such as de la Cadena and Blaser argue-but can be understood as the enactment, stabilisation, and protection of multiple socionatural worlds. ${ }^{10}$ As similarly noted by Li: 'Conflicts over mining reveal the multiple ways of configuring what we usually conceive of as "Nature" and its constituent elements' ( $\mathrm{Li} 2015$ : 22-23).

Considering the intensity of extractive operations in South America over the last two decades, several scholars from different disciplines have explored the significance of these developments, examining the many facets of struggle and protest surrounding extractivism in the twenty-first century (Bebbington and Bury 2014; Deonandan and Dougherty 2016; Arsel et al. 2016; Jalbert et al. 2017). Some studies focus on practices of resistance from a critical ethnographic perspective (e.g., Jalbert et al. 2017) and the implications of extractivism as a catalyst for conflicting conceptualisations of nature, region, and nation (Escobar 2016; Bebbington and Bury 2014), which are often specifically related to different kinds of reactions (usually but not always practices of resistance) to resource extraction. That which distinguishes these studies from the volume we present 
here is our intent to more explicitly relate the current projects and debates of extractivist expansion in South America to the issues of mobilisation, difference, and ontology in local indigenous settings. More specifically, we seek to explore the significance of ontological and cosmological questions to how local populations negotiate and navigate extractive operations and politics. The volume, therefore, addresses ongoing debates on the ontological turn in anthropology, exploring the different ways in which extractivism actualises questions of ontological difference. Our concern is how the intensification of extractivist endeavours in South America actualises issues of both indigeneity and ontology in specific ways and in concrete situations and contexts.

In this Amerindian scenario, politics can be considered to entail questions of fraught and perpetual worldings, which are different although thoroughly imbricated (Povinelli 2001). Politics becomes a cosmopolitics (Stengers 1996) that questions taking human rights as the ultimate justification for claims mobilised through identity politics (Haraway 2008). In this regard, and considering how modern politics is premised on scientific representations of nature, de la Cadena (2014) proposes we explore precisely that which historically falls outside politics-such as earth-beings in the Andes-in order to eliminate the blind spots of modern politics. Such ethnographies may enable us to conceptualise otherwise in partial connection (see Strathern 2004) with difference (which, being located at sites of limit, emerge as radical difference). Indeed, paying attention precisely to such ethnographic (and postcolonial) moments that oblige analysis at the crossroads of ontology and modern politics could open the latter to a more radical critical view (de la Cadena 2014; see also Salmond 2014: 178). Several contributors writing about the ontological turn have considered that, if we are to escape the catastrophic effects of further environmental degradation and climate change, we may need to consider the idea of a 'world not predicated on the essential difference of Indigenous peoples but on our shared capacity to transform ourselves' (Bessire 2014: 227; see also Alberti et al. 2011: 898; Killick 2015).

What happens when the practices and ideologies of extractivism play out in places where the components of the world are otherwise entangled? Further, what would happen if we try to temporarily abstain from seeing resistance and social conflicts as the conceptual points of departure but also as emerging facts from the field? We wish to open the debate also to other possible problems. Do extractivist and Amerindian ontologies differ radically? And, if so, in what ways do they interact or mutually entangle each 
other? Are they, rather, kept separate, and, if so, by what means and under what circumstances? What roles do inequality and asymmetry play in entanglements and separations? Perhaps more importantly, how can we ethically address the suffering, dispossession, destruction, and corruption (Ballard and Banks 2003; Gudynas 2018) that entanglements and asymmetries 'that [admit] no exception and [tolerate] no resistance' (Arsel et al. 2016) provoke in South America? ${ }^{11}$ And, finally, if we are to take these considerations into account, to what extent must we expand our own anthropological concepts in order to grasp 'how "other" the otherwise can be' (Candea 2014) or how 'ontologies multiply' (Law and Lien 2012: 15)?

\section{Identity Politics and Indigenous Mobilisation}

It was not until the 1980s and 1990s, as lowland groups started organising around indigenous identity and demands for territory and highland groups mobilised around cultural recognition and political participation (Postero 2013: 109), that indigeneity emerged as a way of claiming citizenship, rights, and justice. This emergence of indigenous mobilisations and organisations in South and Central America (see, for instance, Warren and Jackson 2002; Ramos 1998; Álvarez et al. 1998; Canessa 2006; Postero 2013) was sparked in part by an international discourse of indigenous rights as well as the more general turn towards identity politics worldwide.

Defining and representing indigeneity is a subject of great debate in South America, as it is elsewhere in the world. Considering the way in which indigenous peoples ${ }^{12}$ tend to be understood and defined in contrast to modernity and that which is associated with the market economy, the relationship between indigeneity and capitalism represents a central theme in anthropological writings. Some scholars have emphasised that capitalism and state-building have, in fact, played an important role in the formation of what we now consider indigenous peoples in South America and beyond. In a comparative study of Asian and African colonisation processes, for instance, Murray Li (2010) argues that practices we associate with indigeneity have grown out of attempts by colonial states to 'protect' natives from market mechanisms. More specifically, she emphasises that indigenous people's collective use of land in Asian and African contexts was developed in response to historical dialectics of capitalism and statebuilding (see also Wolf 1957). Colonial powers relied on collective land use as a way to control and exploit local populations-often combined 
with well-intended attempts to protect them against the 'evils' of capitalism. Similar mechanisms were prevalent in South America, where los indios of the Andes-since the 1570s termed Republica de indios-had to contribute with collective labour and the collection and payment of taxes to the Spanish Crown (Platt 1982; Harris 2000). Through these and similar arrangements, los indios of the Andes have continually been (re)constructed as particular kinds of collective subjects (Wade 2017; Ødegaard 2010 ). This kind of dialectical process indicates the importance of considering how indigeneity may at times act as a tool of governance, while at other times serve as a strategy of emancipation and resistance (Murray Li 2010; Postero 2013). Indigeneity, therefore, cannot be seen as referring to a pre-existing, static formation of identity but, rather, as informed by the complex politics and interdependencies of capitalism and state-building as well as to class, language, ethnicity, and racialised hierarchies in particular contexts. Along these lines, it is widely recognised that we need to 'move beyond thinking of indigeneity in the all-or-nothing terms of authenticity and invention, cultural survival and extinction' (García 2005: 6; see also Li 2015: 117), as indigeneity has increasingly come to be seen as a product of the ways in which 'difference is produced culturally and politically' (García 2008: 217). Postero (2013: 108) similarly finds that the representation of - and representatives of -indigeneity emerge from struggles over particular social, cultural, and economic matters during specific moments. The way in which indigeneity and the indigenous are represented has become a central concern, both among indigenous groups and scholars, especially regarding how to and who should represent the indigenous in postcolonial contexts structured by historical power differences. In addition to the heavy influx of external representations of the indigenous in official as well as scholarly discourses, Postero points out that debates about representation must take into account the issue of internal power and differentiating mechanisms in and among indigenous groups: the involvement of indigenous communities in global identity politics, as well as circuits of capital, may significantly increase internal inequalities and power differences and complicate the issue of representation. Without denying either the existence of forms of community prior to the arrival of extractivist projects to indigenous lands or their role in their own definition, it is important to take into account that 'particular, contingent histories of engagement' around extractivist activities can 'yield specific forms of local community' (Ballard and Banks 2003: 297). According to Murray Li (2010: 400), furthermore, we may need to pay 
ethnographic attention to what Mike Davis (2006: 181) calls the 'microcapitalism of the poor', which may be a pervasive feature of people's livelihoods in cities and countryside alike. Against this backdrop, and seeking to understand how extractivism actualises questions of indigeneity and difference, we suggest that the large-scale enclosures of extractive politics should not exclude sensitivity to the microcapitalism enacted by actors in indigenous communities.

As noted, the 1980s is usually considered as marking the rise of a politics of identity and a shift from a previous class-based mobilisation in Latin America and elsewhere. This shift to an emphasis on identity has been seen as part and parcel of an increasing tendency to make moral claims to land and autonomy during a time when class discourse was losing ground (Orta 2004). In this regard, consider Friedman's (1999) somewhat provocative analysis of identity politics and the rise of indigenous movements worldwide from the 1980s onwards. This rise, he argues, was part of a general process of transformation in the world system and the idea of nationhood, characterised by a rapid increase in economic globalisation and the (supposed) weakening of the nation-state. The transformation produced both globalised (cosmopolitan elites) and localised (indigenous and right-wing) identities and formed the basis for political strategies claiming identitybased rights and cultural liberation from the homogenising force of the state (ibid.: 6). Despite the weakening of class-based mobilisation, Friedman suggests that the dynamics of class formation was, nonetheless, a major operator in the continuum between these different forms of identity, with cosmopolitan elites placed at the top of the system and localisers at the bottom. A whole range of contradictory forces accompanied this process, producing class division and asymmetry at all levels, including within indigenous movements. He relates this process of verticalisation to the involvement of NGOs and international funds in the organisation of local movements. This combination of tribal organisation and capital accumulation produced a tribal capitalist mode (from Rata 1997), Friedman argues, with the potential to produce and reinforce class divisions (1999: 10). This argument suggests that the rise of indigenous movements should not simply be understood as (or reduced to) mere opposition to the changing role of the nation-state under economic globalisation but, rather, considered part of it. Meanwhile, the shift to a focus on identity, culture, and recognition, in both popular and scholarly discourse, has provided common ground for various actors seeking to take cultural difference seriously. According to Fraser (2012), however, and as similarly indicated by 
Friedman, the shift to a politics of identity failed to incorporate a critique of capitalism. In Fraser's view, the politics of identity may even be seen to have emerged in a suspect interrelationship with neoliberalism and as intertwined with global capitalist promotion of an emphasis on language and subjectivity at the cost of social egalitarianism (Fraser 2012: 6).

In this volume, we think of the notion of indigeneity as a dialectical construction that is continually made and re-made through historical encounters, government policies, and indigenous mobilisation. Indigeneity can be seen as both the result and the producer of difference. We would like also to point out our hesitation towards what seems to be a tendency, in some debates and studies of indigenous mobilisation, to deal with the issue of difference merely as a discursive construction. This, we suggest, is to sweep the conceptual and political challenge of difference under the carpet. For instance, in a study of the 1990s Latin American social movements discussing their potential for fostering alternative political cultures, Álvarez et al. (1998) noted that we may need to expand our notion of the 'cultural' and recognise that all social movements (whether class-based or identity-based) can be seen as enacting a politics of cultures. While recognising the contested process of the making and re-making of the indigenous, we argue that we should not overlook the very different cosmological and ontological orientations and dynamics that may be at play and which often become particularly salient, given the frictions caused by the expansion of extractive industries. As has been suggested by various scholars debating from premises of the turn to ontology in anthropology, we need to take these differences seriously (see Viveiros de Castro 2015b; Willerslev 2013). Now, with the current mobilisation around environmental concerns and recent developments of a politics of nature in South America, are we experiencing a new shift towards a wider scholarly consideration of a politics of nature with a potential to reflect on the possibilities of other worlds (see Hage 2012; de la Cadena 2010)? How can current indigenous reactions towards extractive industries be understood vis-à-vis, beyond or away from the identity or cultural politics of the 1980s and 1990s? Could these more recent terms of mobilisation, explicitly linked to a politics of nature, be understood as a continuation or extension of the identity politics of the 1980 s and $1990 \mathrm{~s}^{13}$ ? Or is this a form of mobilisation that should be understood in different terms altogether? Could the recent move towards a politics of nature be seen to entail another (more fundamental) form of critique against capitalism than did the identity politics of the 1980s? In sum, how could an interest in ontological questions be reconciled with the epistemo- 
logical scenario of representation, which, historically, has been privileged by identity politics? Could the aim of a permanent decolonisation of thought be considered a radicalisation of the form of critique brought about by identity politics? In this volume, we contend that the recent academic interests in politics of nature as they are reflected in ethnographies from indigenous South America may come from the potential to include a renewed critique of capitalism and modernity.

\section{From a Politics of Identity to a Cosmopolitics of 'NATURE'?}

The boom in extractive industrial endeavours has been accompanied by an intensification of opposition and resistance to large-scale mining and energy extractive projects in response to persisting inequalities, marginalisation, environmental damage, and ecological devastation. Indigenous world- and life-making projects play a central role in many of these initiatives to mobilise against the politics of extractivism ${ }^{14}$; not only as symbols of resistance but also in making political claims and (for some) in the formulation of alternatives to modern politics and capitalism.

In many cases, the current mobilisations around nature or entities of the landscape are spurred by indigenous people's immediate experiences of loss, alienation, and dispossession related to large extractive operations. The issue of loss associated with extractive industries stems from radical changes to people's ways of life, alteration of their environment and means of subsistence (in some cases through forced displacement), and the often disproportional effects of detrimental by-products from extractive projects (Ballard and Banks 2003). Social scientists refer to these areas, where losses are dismissed as necessary for the benefit of economic development, as human and environmental sacrifice zones (Jalbert et al. 2017; Lerner 2010). A range of issues thus arises when considering Amerindian collectives in the context of globalisation and the extractivist 'translation of nature into resources' (de la Cadena 2014) that exacerbates the world ecological crisis. One of these issues is 'the ecologically destructive and socially disruptive forces' that affect those indigenous people who are struggling to deal with these processes on their own terms (High 2015: 101, 170).

There has been a shift in the narrative framing of indigeneity in the current era, especially in countries such as Bolivia and Ecuador, as suggested by Fabricant (2013). She notes that in Bolivia, in the 1980s and 1990s, 
indigeneity was a language of resistance used for claiming rights as well as reclaiming lands from the oligarchy and transnational corporations. With the government of Morales, the narrative framing of indigeneity has shifted with a broadening of indigenous cosmovision (worldview) to a resource for saving the planet from climate change. Fabricant discusses this as a narrative of indigeneity that Morales has drawn upon in international forums, calling for the adoption of so-called indigenous notions of sumak kawsay (in Quechua) or suma qamaña (in Aymara), usually translated as living well (ibid.; see also Merino 2016). One of the most visible expressions of this shift to a politics of nature may be at the crossroads between indigenous mobilisation, international environmentalism, state governance, and ontologically inflected ethnographic studies. Postero writes that at this meeting of local and global environmental concerns, indigeneity is (once again) made into both a language of governance, a legitimating discourse for the state, and a language of rights employed by citizens demanding access to state resources (2013: 114; see also Postero 2017: 21). This coupling of indigenous notions of sumak kawsay and global environmentalism may produce a range of new dilemmas and contradictions related to what an essentialised notion of indigeneity may mean for large numbers of urban indigenous people, for instance, who might not necessarily oppose resource extraction as such (Fabricant 2013). In this regard, while the Bolivian government's statements about climate change may suggest a clear opposition between indigenous values such as sumak kawsay and capitalism (see also Schavelzon 2016: 121-122), we need to recognise the differing and often conflicting interests among indigenous groups (Fabricant 2013; see also Postero 2013: 113; High 2015 ), their different relations to the extractive industries, and their provisional uses of particular conceptual resources in specific political contexts (Cepek 2016). As noted by Postero, indigenous people remain at the centre of disagreements over the national development models based on natural resource extraction, new forms of government, and relations between the central state and local communities. We are, therefore, compelled to explore the complex ways in which indigeneity is contested and represented in debates over the extractive industry.

Against this backdrop, it is worth asking how the globalisation of discourses on ecological degradation and climate change (through NGOs, governments) serves to inform and spur indigenous mobilisation around the so-called nature. In other words, how is indigenous politics of nature related to other kinds of mobilisation and protests and to international 
environmental discourse more widely (see Li 2015; Postero 2013; Fabricant 2013; see also Li and Paredes Peñafiel, this volume)? How can we relate the simultaneity of different mobilisations concerning 'nature' to the radical alterity of indigenous ontologies? Considering the recent mobilisation against extractive industries in many countries, Li's ethnography of the mobilisation around particular entities of the landscape documents how such mobilisation sometimes crosscuts conventional groupings related to class or ethnic identity, involving peasant and indigenous communities, NGOs, and transnational environmentalists. Li reminds us that actions often defined as indigenous knowledge or tradition are not fixed entities, since arguments that appeal to such notions are made from localglobal encounters (2015: 220). For instance, in Porcón, one of the communities where she worked, Li illustrates how it took a proposed mining project-with the threat of open pits, chemicals, and altered water courses - to actively produce the 'indigeneity' of her interlocutors and to make their relationship to a sentient landscape politically visible and significant in the present (ibid.: 116-117). This is an important point, but should not, in our opinion, undermine the gains of ethnographic expositions to Amerindian ontological patterns and alternative compositions of the world (see Pazzarelli 2013; Alberti et al. 2011; Nielsen 2016; Rivera Andía 2005a, b, 2006, 2008; Fortis 2014; Alberti 2014; Harris 2000; Orta 2004), particularly when both approaches could actually benefit and inform each other.

Reflecting on the interconnectedness with worldwide discourses on rights and recognition, Steur (2014) notes that indigenous movements often rely on a contradictory mix of epistemologies - of legally and scientifically prescribed identification, popular revisioning of historical memory, references to differing political ideologies, and attempts to appeal to middle-class imaginaries of indigenousness (see also Li 2015; Postero and Fabricant, this volume). Against this backdrop, and referring to indigenous movements in India, Steur (2014: 2) argues that it would be a mistake to read indigenous mobilisation only in terms of an ontological critique of Western modernity. She identifies problems in what she considers a recent tendency in studies of indigenous movements to reduce them to a question of 'ontological critique' and, more importantly, to engage with the question of capitalism only to the extent to which it represents yet another problem of Western ontology (see also Bessire 2014). This tendency, which some authors consider a price worth paying (Candea 2017), invites the risk that the historical, real, and relational process of capitalism 
is sidestepped, culturalised, or even reduced to Western myth (or ontological dualisms). In order to understand the emergence and, not least, the timing of indigenous movements and politics, Steur argues that we need to sharpen our understanding of how capitalist mechanisms work themselves out and are renegotiated in people's everyday working lives, organised collectivities, and socially reproductive activities (Steur 2014: 2). In accordance with this point by Steur, our volume focuses on indigenous responses to extractive industries in an attempt to reveal how these endeavours play out in everyday lives, and, further, we explore how ontological differences might inform these processes and responses. We consider that the examination of capitalist expansion and extractivism could benefit from a focus on the significance of ontological difference to understand how these processes are dealt with, lived, negotiated, and altered by local indigenous populations. As noted by Blaser (2004), while indigenous communities all over the world have opposed many developmentalist agendas, their agendas are themselves emergent rather than a mere reaction to other agencies.

Our concern with cosmologies and ontologies in this volume certainly does not entail an assumption that indigenous world- and life-making projects necessarily take the form of opposition or resistance to extractive endeavours. In fact, the volume is not limited to the issue of protest, mobilisation, or politically motivated actions; we are also interested in rather ambiguous situations where ontological principles are made relevant as part of indigenous peoples' way to make sense of their life-making projects alongside extractivist endeavours. In this respect, we build on Blaser's (2004) focus on how people sustain life projects that are embedded in local histories and visions of the world and the future that are distinct from those promoted by state and markets. Underlining how indigenous communities do not necessarily resist development, Blaser argues that struggles to pursue life projects, often 'premised on densely and uniquely woven "threads" of landscapes, memories, expectations and desires', may be at least equally important to chronicle and analyse (Blaser 2004: 26). Along these lines, our intention is to explore the dilemmas, frictions, and uncertainties arising from the complex coexistence of a global hegemonic notion of nature as resource on the one hand and various Amerindian socionatural formations on the other hand. We are thus required to uncover the variety of ways in which indigenous ontogenies ${ }^{15}$ are configured and re-accommodated in people's attempts to resist, to make sense of, or simply survive in contexts of extractive industry activity in South America. Hence, our wish 
to show the significance of different life- and world-making projects in everyday lives. We find this to be a useful approach particularly in a context of ongoing and heated debates about a tendency in the ontological turn in anthropology to fix differences and to restrict itself to the domains of abstract and generalising discussion of rigid 'ontological schemes' (Vigh and Sausdal 2014). To elude a presupposition of ontology as worlds separated by incommensurable differences, we propose to consider the expansion of extractive industries in South America (and indigenous peoples' attempts to deal with it) through concepts such as ontological dynamics (see Remme 2016) or ontogénies (Ingold in Descola and Ingold 2014). An emphasis on ontological dynamics in such encounters involves a concern with the emergence of boundaries and entities as an effect of specific practices, especially attempts to stabilise and contain the entities and boundaries that extractivism makes visible, uncertain, or nonexistent.

\section{Final Thoughts on Life Projects and Turbulences}

Extractivism stands out among the remarkable challenges associated with ideologies and processes of globalisation that Amerindian collectives of South America are facing. Taking into account this encounter between different perspectives, ideologies, and praxes-by no means new but in many cases affected by a sort of acceleration (Brightman et al. 2016:2) —scholars concerned with indigenous societies have had to broaden the scope of their reflections and adopt new analytical tools. In this context, some scholars have aimed to show ethnographically how 'the modern world or ontology sustains itself through performances that tend to suppress and or contain the enactment of other possible worlds' (Blaser 2009: 16):

[C]ommoning comes at the cost of subordinating one set of practices to the other through "same-ing"-that is, an equivalence is proclaimed (and accepted) where a divergence is actually operative. The consequence is that dominant practices can eventually operate as if the subordinate ones were irrelevant to the constitution of the commons (Blaser and de la Cadena 2017: 190).

Suppression and subjection (Escobar 2016: 15) are also implicit in the imposition described as part of a war of worlds: "the world ("as we know it") is imposed in myriad ways on other peoples' worlds (as they know them), even as this hegemonic world seems to be on the brink of a slow, painful and ugly ending' (Viveiros de Castro 2015b; see also Schavelzon 2016). ${ }^{16}$ 
Along these lines, some scholars insist that culture, as opposed to nature, would not be sufficient to understand the challenge represented by contemporary indigenous politics and the quest to promote indigenous rights (Blaser 2009; de la Cadena 2010, 2015). The challenge of this 'transition to who knows what' (Gilbert in Haraway et al. 2016: 541) concerns an ontological politics, a cosmopolitics, by which different possible entanglements between humans, nonhumans, and places become occasions for ethical controversy (Wardle and Schaffner 2017: 9-24). Contemporary indigenous movements fighting against the predatory policies of multinationals are concordantly perceived as a way to re-establish the sovereignty that humans and nonhumans exercise over themselves (Descola 2014b: 55).

Previous attempts to conceptualise the involvements of indigenous peoples in a globalised economy have tended to focus on their relationship with external extractivist agents in terms of individualism, monetisation, inequality, and resistance produced in the relation to capitalist modes of production. Seeking to expand from these conceptualisations, we wish to explore how Amerindian groups can maintain their ability to be part of a localised (place-based) community in a socially legitimate manner while simultaneously facing the challenges produced by, for example, the forceful expansion of a monetary economy and wage labour accompanying the extractivist industries. We intend neither to deny the depth of the transformations of indigenous life projects caused by extractivism nor assert its ineluctability or radicalness. Instead, we would like to test the possibility that changes in Amerindian collectives could follow indigenous patterns identified across diverse Amerindian regions (Fausto 2012 [2001]; Gutiérrez 2001; Rivera Andía 2005a, b, 2008; Erikson 1986, 1999; Santos-Granero 2009; Ortiz Rescaniere 1999; Pitarch 2003; Viveiros de Castro 2004a, 2011). How do the different strategies used by indigenous groups and communities to incorporate the external otherwhich is often seen as an indispensable feature of the making of the self (Viveiros 2004a: 475; High 2015)—operate in extractivist contexts?

Further, how could we reintroduce a kind of morality into our relationships with nonhuman environments (Hornborg 2006: 25), when we have for centuries deprived nature of morality (Callicott 1989, Berkes 2005, Kapfhammer 2012), historicity, and 'the inner narrativity that is part and parcel of being in the world' (Latour 2014: 13)? This ethical issue raises the question of whether the ontological turn blurs the other's suffering and devastation (see Escobar 2016: 23). Or, put differently, is this anthropology of ontology... 'with the potential to revolutionise anthropological practice and even save the planet from ecological apocalypse' (Scott 2013: 860) 
indeed hampering much needed situated analyses of afflictions and struggles? Would those proposals in which indigenous people are deemed as an environmental remedy to the behaviour of the West (Killick 2015) constitute nothing but a 'problematic form of speculative futurism' (Bessire and Bond $2014 \mathrm{c}$ )? Moreover, is this a sort of futurism where some life-making projects have priority over others, thereby doing a disservice to the complexity of indigenous ways of living (Bessire 2014: 228; Killick 2015; see also Kapfhammer 2012: 149-152)? Facing these issues, the chapters compiled in this volume aim to provide descriptions of South American life projects that are being troubled, subdued, ignored, or 'actively produced as non-existent' (Escobar 2016: 15) by current policies of extractivism (Schavelzon 2016). We seek to address the unfolding of indigenous life projects in extractivist contexts in line with the proposition of an ontographic method (Holbraad 2009), as a way of avoiding conceptual imperialism and the imposition of our own categories and assumptions. Without dismissing conceptual reflexivity, we want to address and describe people's life projects more specifically in contexts of extractivism, including their sufferings, adversities, and struggles. We strive to avoid any type of prophetic conceptual futurism (Bessire 2014) - predefining, for example, indigenous peoples as hostages of some notion of indio ecologico-and, rather, pay attention to the coercive or punitive actions related to ongoing extractivism. Instead of persisting to simply apply our own pre-conceptualisations about extractivism's specific effects, however, we try to explore indigenous experiences of loss and suffering as a function of the (imposed) inability to gain, realise, or obtain one's own life project. We would like this to be our contribution to the literature as well as to debates about extractivism in South America, by showing the relevance of conceptual reflexivity to produce ethnographic accounts of extractivist Amerindian contexts' asymmetry and suffering. We draw on various contributors to the debates on the ontological turn and their emphasis on ethnographic conceptual reflection (see Holbraad 2014) while suggesting that an 'ontological opening' (de la Cadena 2014) to people's urgent circumstances (Bessire 2014) may also contribute to ways of thinking otherwise.

\section{The Chapters of This Book}

The chapters of the volume address, within various ethnographic contexts and from different points of view, the issues, controversies, and questions of three broad topics currently relevant when dealing with extractivism in 
Amerindian South America: the reactions to, access to, or deprivation of the wealth linked to extractive industries (Guzmán-Gallegos, Penfield, Krøijer and Ødegaard); the conceptualisations and practices associated with territory and land ownership (Stensrud, Rivera Andía and Brightman); and the political reactions of indigenous peoples through the evolution of activism and the concept of indigeneity ( $\mathrm{Li}$ and Paredes Peñafiel, Postero and Fabricant).

Part I, Flows, Wealth, and Access, considers the Kichwa people in the Upper Tigre River near the frontier between Peru and Ecuador (GuzmánGallegos), the Sieko-pai (or Secoya) of northeastern Ecuador (Krøijer), the Sanema of Venezuelan Amazonia (Penfield), and the Andean smugglers working in the frontier between Peru and Bolivia (Ødegaard). In each of these cases, the authors highlight local indigenous communities' strategies to face asymmetries and turbulences created by extractivism in their worlds.

María Antonieta Guzmán-Gallegos' chapter examines the diverse and changing ways in which the Kichwa people relate to the leftovers of oil extraction in their everyday lives in the Upper Tigre River. She explores different types of abandoned oil installations and toxic waste that are part of landscapes of rubble saturated by ruination processes. The chapter shows how rubble and ruination embody the expansion of extractive capitalism in northern Peruvian Amazonia. This expansion entails a persistent disregard, both corporate and state, of the Kichwa people's ways of life, a disregard which constitutes them as disposable and the places they inhabit as sacrifice zones. It suggests that the Kichwa's current attempts to take control (a topic also addressed by Krøijer, and Rivera Andía) over abandoned oil installations and the remaining toxic wastes are acts of contestation. Their attempts at control, the author argues, are a rejection of the negation of their existence. The chapter shows that these attempts are, at the same time, an actualisation of divergent notions of ownership and their enactments (a topic also addressed by Brightman, Stensrud and Rivera Andía). Guzmán-Gallegos suggests that this actualisation multiplies the object owned. For the Kichwa, owned land is both the result of acts of care and transformation as well as legally titled area. While the first form of land ownership manifests and is a product of the relations of the people living in a place, titled land materialises their relationship with the state. The author proposes that, through multiplication of what is owned as well as the articulation of distinct enactments and understandings of ownership, the Kichwa seek to redefine the overwhelming asymmetries that characterise their long-standing relations with the state and other nonindigenous actors. 
The chapter by Stine Krøijer considers the devastating social and environmental consequences of the constant penetration of the extractive frontier into indigenous territories in northeastern Ecuador. She explores the strategies followed by the Sieko-pai (formerly known as Secoya) living in or near oil fields for dealing with the transformations suffered by their world during decades of oil extraction. How do they, in fact, maintain a sense of control over their lives in the encounter with the extractivist imperative in its Ecuadorian version? Documenting the Sieko-pai's considerations about the disruptions-caused by the incorrect treatment of oil and blood-of positive 'flows' between powerful others (from jaguars to private companies) and indigenous territories and bodies, Krøijer pursues the analytical implications of a specific enquiry concerning indigenous life projects in a world saturated by extractivism. Her chapter contributes to current debates around the ontological analogy between oil and the socalled subterranean spirits' blood without amounting to either an indigenous submissive acceptance or a heroic resistance of the circumstances externally inflicted on them. Instead, the author shows us that living with oil extraction expresses the Sieko-pai's flexible ability to control a set of transformations in their world with their own life-project agendas.

The chapter by Amy Penfield explores more understated and multifaceted responses to extractivism that differ from the common depictions of indigenous resistance to extraction. These resounding tropes, while accurate representations of extraction in many cases, often eclipse the ways in which indigenous responses may be more layered and perhaps even interwoven with their social and cosmological ethos. Drawing on field research among the Sanema of Venezuelan Amazonia, Penfield demonstrates how extractivism and its products, as well as associated wealth are integral to the Sanema livelihood and transforming notions of personhood in unanticipated ways. Their unique location in the resource-rich forests of the Venezuelan petro-state means that extraction has a twofold bearing on their lives: first, as an abstract phenomenon in the form of oil wealth dispensed to citizens and, second, as the intimate reality of gold mining in their territory. Both forms of extraction have manifold and significant impacts. Contrary to the perception that incorporation into the extractive economy brings with it individualism and social degeneration, Penfield's chapter vividly shows how the wealth associated with extraction may also facilitate sociality, reciprocity, and compassion among kin (a similar situation is described in Ødegaard's chapter). Wealth, among the Sanema, is found in human relationships, not self-interest. 
The chapter authored by Cecilie Vindal $\varnothing$ degaard leaves the rural settings of most of the chapters for an urban one, describing issues related to those of Krøijer and Penfield. Ødegaard focuses on the smugglers of fuels who operate in the frontier between Peru and Bolivia. Despite their strong Aymara and Quechua origins, the contrabandistas have usually been addressed by ethnographies more interested in economic 'informality' in South America (Goldstein 2016) than in Amerindian worldviews. Instead, Ødegaard considers the labour of contrabandistas as a redirection of commodities from official circuits of distribution (in this case, fossil fuels) and explores how the practices of contrabandistas contribute to subsume wealth to particular modes of sociality, including relations with market colleagues, kin, and earth-beings. Translating from one form of value accumulation to another, more redistributive form, these actors' life projects are aimed at recreating local forms of relatedness. Both redistribution and translation here entail a semiotic multiplication involving different systems of meaning that exceed what the author calls the capitalist system of commensuration: a hegemonic, modernist production of equivalence supported by narratives of progress and development that usually accompany extractivism in South America. By exploring commodity flows as well as contrabandistas' relations to the powerful earth-beings of the Andean landscape, Ødegaard reveals the partial connections of locally embedded worldings and dominant extractive practices. As in other chapters of this book, and without dismissing the consequences of accumulation and inequality in the Andes, Ødegaard finds that resistance to extractivism is not absolute. Instead, the author describes a set of strategies used to deal with the forces and wealth of extractivism while paying attention to the relational and cosmological aspects of wealth and its mediation; here termed accumulation by diversion.

In Part II, Extractivism, Land, Ownerships, Stensrud writes about the Quechua indigenous communities in the Arequipa highlands (Peru). Rivera Andía offers an ethnographic account of the Cañaris people (also in Peru but around 2000 kilometres north of Arequipa). And, finally, Brightman describes the case of the Trio in Suriname. These three chapters consider the issue of indigenous conceptualisations and assertions of ownership and management of lands in contexts that are not often addressed directly in the literature on extractivism: 'spectral' mining projects, megaprojects of channelling water for agroindustry, and hydroenergy and, last but not least, quantification of biodiversity and forest carbon.

Astrid Bredholt Stensrud suggests that earth-beings in the southern Peruvian context are not necessarily or deliberately invented as an indigenous strategy to stop extractivism, but, rather, form facets of relationships 
that are continuously nurtured as part of ongoing local life projects. While most studies focus on the boom in oil, minerals, and logging, Stensrud's chapter explores another form of extractivism which is growing in importance in Peru and elsewhere: the extraction of economic value from water in infrastructural mega-projects for the damming and channelling of water. She examines the implications of the Majes Irrigation Project for Quechuaspeaking farmers and how they make claims to the water located within their lands. More specifically, she explores the conditions that make these land claims possible and how they are connected to notions of belonging and ownership that emerge from particular ontological compositions of water, mountains, personhood, earth-beings, and other nonhuman entities. These compositions and the life projects associated with them, Stensrud argues, conflict with the extractivist and modernising project of colonising water by turning it into an economic resource.

The chapter by Juan Javier Rivera Andía explores the terms by which the Cañaris Quechua-speaking people of the northern Peruvian highlands establish their relationship with the 'land' in a local context marked by extractivism. The extraction of resources implies taking the local places inhabited by the Cañaris people as an inert 'natural' land-object that is susceptible to being used and appropriated without much attention to what a president of Peru recently called 'absurd ideologies'. The author examines the conflicting ways in which land is experienced and understood in an area with evergrowing social conflicts linked to mining in Peru. Leaving open the possibility of the radically distinct multiplicity of a 'living' environment with whom humans relate in 'social' terms (illustrated also by Stensrud and by Ødegaard) that exceeds but is entangled with modern European conceptions of private property, he describes local practices and conceptions concerning the production, access, and administration of the land (also addressed by Brightman). What emerges then is a nonhuman entity that is less 'natural' and 'indigenous' than what is usually expected in this type of ethnographic account: the Iglisya (Quechua term that comes from the Spanish iglesia, church). This indigenous building not only represents the land but constitutes it; it is the land (or what we could expect to find in Cañaris when arriving with such a concept in mind). Distant from combative public speeches, environmental activism, or 'classic' Andean nonhuman beings, the prevalence of the material, collective, and nonverbal aspects of the relationships that produce the Iglisya, might, in fact, constitute a truly cosmopolitical and powerful fighting device to contend on their own terms (which Krøijer also addresses) with the threat currently suffered by the Cañaris. In Cañaris, 
extractivism is affecting not only the rights of an indigenous people but a particular way to compose the world, a form that should be taken into account in any serious attempt to define key concepts in Andean ethnography (such as 'communal lands' or comunidad campesina).

Marc Brightman's chapter discusses the works of international environmental NGOs that seek to conserve biodiversity among native Amazonian people in Suriname as a nonconventional form of extractivism. As recognised in various cases, these efforts are increasingly inserted in a globalising modern worldview associated with refined techniques for the monitoring and (more importantly) the quantification of biodiversity and forest carbon. Addressing the significances for the Trio of this relatively new economic, political, and ideological context promoted by the liberalisation of conservation, the author explores how indigenous conceptualisations (for instance, those regarding land ownership) contrast and entangle with the perspectives of technical and governmental agents intervening in their territory. Thanks to this comparative view, Brightman allows us an ethnographically informed insight into the different sets of distinctions and continuities between carbon and biodiversity accounting and other more conventional forms of extractivism taking place in indigenous worlds.

Part III, Indigeneity, Activism, and the Politics of Nature, is somewhat less interested in debates on ontology and comprises two co-authored chapters. The first, by Li and Paredes Peñafiel, discusses central leaders of anti-mining activism in both Peru and Brazil. The second study, by Fabricant and Postero, focuses on the conflicts around the construction project of a highway that traverses the Bolivian Isiboro Sécure National Park and Indigenous Territory (abbreviated as TIPNIS in Spanish). Both chapters offer detailed descriptions of events known nationally and internationally and that are still evolving.

The chapter by Fabiana Li and Adriana Paredes Peñafiel explores the manifold interconnections between community-based resistance and national, as well as international activist networks. Focusing on organised resistance to mining activity (including indigenous peoples but also other actors) in Peru's northern highlands (neither geographically nor culturally far from the region studied in Rivera Andía's chapter), the authors trace the opposition to a proposed mining project (the Conga campaign) and the dynamics that arise when local activism travels through documentaries, news media, lawsuits, and networks. Analysing the international reverberations of the conflict and activist efforts, they describe the emergence of key leaders-particularly female ones - and how they and media actors represent the conflict. In so doing, they explore the translation of these (media) representations from the 
Peruvian context to a situation of increasing open resistance among scholars and middle-class activists to resource extraction in Rio Grande del Sul, Brazil. The authors document how this resistance may reverberate elsewhere and discuss its potential to challenge the logic of extractivism by opening up a space for alternative life-making projects that both transcend and communicate between connections to a local landscape.

Addressing how indigeneity is actualised in social mobilisation, Nicole Fabricant and Nancy Postero examine the ways in which indigeneity is performed in Bolivia. Focusing on current protests against the construction of a highway through indigenous territories, they consider how performance can play a central role in what they call moral reflection about indigeneity, gender, and the articulation of alternative social worlds. Using the concept of 'ethical substance' (Povinelli 2012), the authors explore how, through performance, indigeneity serves as a central site of moral reflection and conduct in their particular ethnographic settings. In so doing, they show how protests and performance also call into question the legitimacy of the Evo Morales government's claim to stand for all indigenous peoples. The chapter demonstrates how distinct actors may claim access to indigeneity, and that multiple actors perform indigeneity to push through their own ethical and political agendas.

In sum, the third section of this book deals with widely held notions and practices linked to activism and indigeneity in current (and different) South American national scenarios. Extractivism is here expressed either directly, as in an open-pit mine, or indirectly, as in a highway project. In contrast to this section, the first two parts of the book explore local indigenous situations. The second part deals with relatively less frequently described forms of extractivism: the conflicts over an extraction yet to come in the Andes, the fight to control a substance as scarce as water in relation to an agroindustrial project, and the not so visible consequences of quantification of carbon and biodiversity in forest in Amazonia. In all these cases (and also in other sections of the book, although to a varying extent), the chapters highlight the diverse entanglements of humans and nonhumans and the reconceptualisation that these entanglements require. Finally, this brings us back to the first part's descriptions of the diverse strategies indigenous peoples and urban proletarians use to face extractivism in their life-making projects in South America. Here, humans and things (such as rubble, abandoned wells, irrigation canals, ritual offerings, and gas cylinders) are not only entangled but might also mutually constitute each other in the mist of the asymmetric turbulences emerging from South American extractivism. 


\section{Notes}

1. We build here on Blaser's (2004) focus on how people sustain life projects that are embedded in local histories and visions of the world and the future distinct from those promoted by state and markets.

2. As is well known, animism is one of the oldest concepts in anthropology, representing the 'century-old problem [of] why people animate what we regard as inanimate objects' (Bird-David 1999: 70). In fact, ethnologists' efforts to understand this 'bizarre scandal' (Kohn 2009: 136) could be traced at least to the seminal work by Edward B. Tylor (1871) who explained 'animism' in accordance with David Hume's thesis in Natural History of Religion (Brightman et al. 2012: 3) and the German protovitalist Ernst Stahl (Halbmayer 2012: 9). After more than a century, this attribution of a social character to relations between humans and nonhumans is traditionally understood as configuring a world in which the default form of interaction between beings is modelled on that which occurs between subjects (Costa and Fausto 2010: 94).

3. Debates about the turn to ontology are often complicated-or perhaps enriched - by the variety of definitions and uses of the term ontology. Most of its proponents attempt to decentralise what being human entails and apply the porous or negotiated nature of its boundaries to other species and materialities (Bertelsen and Bendixsen 2016: 7). For instance, Scott (2013: 859) defines ontology as 'the investigation and theorization of diverse experiences and understandings of the nature of being itself'. Our discussion of the question of ontology in this introduction is by no means intended to provide an exhaustive account of the contributions and debates in its wake, as comprehensive overviews of these debates have been provided elsewhere (e.g., Holbraad and Pedersen 2017; Kohn 2015; Alberti et al. 2011; Bertelsen and Bendixsen 2016).

4. Rivera Andía's translation.

5. Rivera Andía's translation.

6. The fall of prices was caused partly by US oil sands production. In the period 2011-2015, a nearly 50 per cent fall in the prices of raw materials and energy (oil, gas, carbon) directly affected countries, such as Bolivia, Colombia, Ecuador, Venezuela, Chile, and Peru, that export hydrocarbons and metals.

7. This approach allows us to include, along with mining and oil extraction, fishing and cocaine production among extractivist activities in South America. It should be recognised that, either because of tacit consideration as a nonconflicting activity (as fishing) or as too conflictive (as narcotraffic), both are social, political, and economic extractivist activities that are still not being as closely studied as, for instance, 'petro-cultures' (e.g., Cepek 2016). 
8. Based on the International Labour Organization Convention 169 and the Native Communities Law which have been signed by several governments in South America between 1991 and 2008, through which states are expected to recognise indigenous land rights, and which later, at least on paper, have been reinforced by laws pertaining to participation and prior consultation.

9. Because of the shift towards a capital-intensive dynamic instead of a labourintensive one.

10. This form of detection and inclusion of entities such as spirits of the mountains in current anthropological ethnographies has been labelled as a version of the ontological turn called 'alternative ontology': 'a highly influential theoretical intervention in political and political-economic anthropological debates' (Holbraad and Pedersen 2017: 52) that nevertheless 'still operate[s] by grounding the possibility of political difference in a prior story of how the world(s) must work' (Holbraad and Pedersen 2017: 54; see also Mol 1999; Latour 2014).

11. A whole range of issues could be drawn from this single question. What are, for instance, the implications of addressing it from outside of the Global South or, more precisely, from those 'rich nations' which Chakrabarty considers guilty of 'the current crisis' (2009: 216)? How to compose a common world thinking, as Stengers (2005) puts it, 'in the presence of' those most negatively affected by extractivism from a 'North' sometimes imagined as free of the conditions and consequences of the inequalities that characterise the South American scenarios described in this book? Finally, and regarding only the domain of the production of anthropological knowledge, how could the asymmetries between hegemonic and marginal narratives and groups taking place in different parts of the world (Narotzky 2010) be put into a productive dialogue?

12. Being defined through their historical use of and belonging to a certain area and the rights attached through collective use of this land, indigenous peoples are further ascribed cultural specificities that often have bearing on their practices related to the land.

13. Indigenous mobilisation in this period certainly included land and titling as part of their claims for cultural rights. We should also be aware that this periodisation may overly simplify struggles that were in fact multifaceted and entailing not only questions of language and culture (but whose acknowledgement mainly in terms of language and cultural expression may have been in the interest of national governments).

14. The same could be said to happen against the developing clean energy projects driven by the increasing demand for energy in South America (Howe 2015). 
15. We take this term from Tim Ingold, who uses it in several works 'to describe how form, rather than being applied to the material, is emergent within the field of human relations. This is neither making nor growing, but a kind of making-in-growing, or growing-in-making' (Ingold and Hallam 2014: 5). Or put differently: 'What if we were to reverse our priorities, and subsume making under growth? Would not the concept of agency then take second place to that of animacy, as embodiment would take second place to ontogenesis, and being to becoming?' (Ingold and Hallam 2014: 17; see also Ingold 2013: 95-97; Descola and Ingold 2014).

16. Similar positions have been delineated by Latour: 'There is no such a thing as a "common world." The issue of vegetable oil fuels is a war' (Latour 2015, authors' translation). 'War is infinitely more likely than contract' (Latour 2014: 5). In the case of scholars working on South America, this position resonates with those of Escobar referring to the 'struggles for the defense of territories and difference' (2016: 13) and Schavelzon regarding the project of a Bolivian constitution (2016: 126).

\section{REFERENCES}

Acosta, Alberto. 2011. Extractivismo y neoextractivismo: Dos caras de la misma maldición. In Más allá del desarrollo, ed. M. Lang and D. Mokrani, 83-120. Quito: Abya Yala y Fundación Rosa Luxemburg.

- 2013. Extractivism and Neoextractism: Two Sides of the Same Curse. In Beyond Development: Alternative Visions from Latin America, ed. M. Lang and D. Mokrani. Quito: Abya Yala y Fundación Rosa Luxemburg.

Alberti, Benjamin. 2014. Designing Body-Pots in the Formative La Candelaria Culture, Northwest Argentina. In Making and Growing: Anthropological Studies of Organisms and Artefacts, ed. Elizabeth Hallam and Tim Ingold. Farnham: Ashgate Publishing.

Alberti, Benjamin, Severin Fowles, Martin Holbraad, Yvonne Marshall, and Christopher Witmore. 2011. "Worlds Otherwise": Archaeology, Anthropology, and Ontological Difference. Current Anthropology 52 (6): 896-912.

Álvarez, Sonia E., Evelina Dagnino, and Arturo Escobar. 1998. Cultures of Politics, Politics of Cultures: Re-envisioning Latin American Social Movements. Colorado/Oxford: Westview Press.

Ansión, Juan. 1987. Desde el rincón de los muertos: el pensamiento mítico en Ayacucho. Lima: GREDES.

Arsel, Murat, Barbara Hogenboom, and Lorenzo Pellegrini. 2016. The Extractive Imperative and the Boom in Environmental Conflicts at the End of the Progressive Cycle in Latin America. The Extractive Industries and Society 3: 877-879. 
Ballard, Chris, and Glenn Banks. 2003. Resource Wars: The Anthropology of Mining. Annual Review of Anthropology 32: 287-313.

Bebbington, Anthony, and Denise Bebbington. 2012. Post-What? Extractive Industries, Narratives of Development and Socio-Environmental Disputes across the (Ostensibly Changing) Andean Region. In New Political Spaces in Latin American Natural Resource Governance, ed. H. Haarstad. London: Palgrave Macmillan.

Bebbington, Anthony, and Jeffrey Bury, eds. 2014. Subterranean Struggles: New Dynamics of Mining, Oil, and Gas in Latin America. Austin: University of Texas Press.

Berkes, Fikret. 2005. Traditional Ecological Knowledge. In Encyclopedia of Religion and Nature, ed. Bron Taylor. London: Thoemmes Continuum.

Bertelsen, Bjørn Enge, and Synnøve Bendixen, eds. 2016. Critical Anthropological Engagements in Human Alterity and Difference. London: Palgrave Macmillan.

Bessire, Lucas. 2014. Behold the Black Caiman: A Chronicle of Ayoreo Life. Chicago: University of Chicago Press.

Bessire, Lucas, and David Bond. 2014a. Ontological Anthropology and the Deferral of Critique. American Ethnologist 41: 440-456.

- 2014b. Ontology: A Difficult Keyword. Virtual Issue, Ontology in American Ethnologist, 1980-2014. http://onlinelibrary.wiley.com/journal/10.1111/ (ISSN)1548-1425/homepage/virtual_issue_ontology.htm. Accessed 19 Mar 2016.

- 2014c. The Ontological Spin. Cultural Anthropology Online. http://www. culanth.org/fieldsights/494-the-ontological-spin. Accessed 19 Mar 2016.

Bird-David, Nurit. 1999. 'Animism' Revisited: Personhood, Environment, and Relational Epistemology. Current Anthropology 40 (1): 67-91.

Blaser, Mario. 2004. Life Projects: Indigenous People's Agency and Development. In In the Way of Development: Indigenous Peoples, Life Projects, and Globalization, ed. M. Blaser, H.A. Feit, and G. McRae. London/New York: Zed Books.

- 2009. The Threat of the Yrmo: The Political Ontology of a Sustainable Hunting Program. American Anthropologist 111 (1): 10-20.

Blaser, Mario, and Marisol de la Cadena. 2017. The Uncommons: An Introduction. Anthropologica 59: 185-193.

Blaser, Mario, Harvey Feit, and Glenn McRae, eds. 2004. In the Way of Development: Indigenous Peoples, Life Projects, and Globalization. London/ New York: Zed Books.

Boellstorff, Tom. 2016. For Whom the Ontology Turns: Theorizing the Digital Real. Current Anthropology 57 (4): 387-407.

Bridge, Gavin. 2004. Mapping the Bonanza: Geographies of Mining Investment in an Era of Neoliberal Reform. The Professional Geographer 56 (3): 406-421.

- 2008. Global Production Networks and the Extractive Sector: Governing Resource-Based Development. Journal of Economic Geography 8: 389-419. 
Brightman, Marc, Vanessa Grotti, and Olga Ulturgasheva, eds. 2012. Animism in Rainforest and Tundra: Personhood, Animals, Plantsand Thingsin Contemporary Amazonia and Siberia. New York/Oxford: Berghahn Books.

Brightman, Marc, Carlos Fausto, and Vanessa Grotti, eds. 2016. Ownership and Nurture: Studies in Native Amazonian Property Relations. New York/Oxford: Berghahn Books.

Bunker, Stephen G. 1984. Modes of Extraction, Unequal Exchange, and the Progressive Underdevelopment of an Extreme Periphery: The Brazilian Amazon, 1600-1980. American Journal of Sociology 89 (5): 1017-1064.

Callicott, J. Baird. 1989. In Defence of the Land Ethic: Essays in Environmental Philosophy. Albany: State University of New York Press.

Candea, Matei. 2014. The Ontology of the Political Turn. Cultural Anthropology. https://culanth.org/fieldsights/469-the-ontology-of-the-political-turn. Accessed 18 Jan 2018.

- 2017. We Have Never Been Pluralists: On Lateral and Frontal Comparisons in the Ontological Turn. In Comparative Metaphysics. Ontology After Anthropology, ed. P. Charbonnier, G. Salmon, and P. Skafish. London/New York: Rowman \& Littlefield.

Canessa, Andrew. 2006. Todos somos indigenas: Towards a New Language of National Political Identity. Bulletin of Latin American Research 25 (2): 241-263.

Caro, Tim, Jack Darwin, Tavis Forrester, Cynthia Ledoux-Bloom, and Caitlin Wells. 2012. Conservation in the Anthropocene. Conservation Biology 26 (1): $185-188$.

Carstensen, Jeppe. 2014. Capturing the Anthropocene: Sensory Ethnography in Anthropogenic Biomes. Master's thesis, Lund University.

Cepek, Michael. 2016. There Might be Blood: Oil, Humility, and the Cosmopolitics of a Cofán petro-being. American Ethnologist 43 (4): 623-635.

Chakrabarty, Dipesh. 2009. The Climate of History: Four Theses. Critical Inquiry 35 (2): 197-222.

Chiasson-LeBel, Thomas. 2016. Neo-Extractivism in Venezuela and Ecuador: A Weapon of Class Conflict. The Extractive Industries and Society 3: 888-901.

Corsín Jiménez, Alberto, and Rane Willerslev. 2007. 'An Anthropological Concept of the Concept': Reversibility Among the Siberian Yukaghirs. Journal of the Royal Anthropological Institute 13: 527-544.

Costa, Luiz, and Carlos Fausto. 2010. The Return of the Animists: Recent Studies of Amazonian Ontologies. Religion and Society: Advances in Research l (1): 89-109.

Course, Magnus. 2010. Of Words and Fog: Linguistic Relativity and Amerindian Ontology. Anthropological Theory 10 (3): 247-263.

Davis, Mike. 2006. Planet of Slums. London/Brooklyn: Verso.

de la Cadena, Marisol. 2010. Indigenous Cosmopolitics in the Andes: Conceptual Reflections Beyond 'Politics'. Cultural Anthropology 25 (2): 334-370. 
2014. The Politics of Modern Politics Meets Ethnographies of Excess through Ontological Openings. Theorizing the Contemporary. Cultural Anthropology Online. http://www.culanth.org/fieldsights/471-the-politicsof-modern-politics-meets-ethnographies-of-excess-through-ontologicalopenings. Accessed 19 Mar 2016.

. 2015. Earth Beings: Ecologies of Practice across Andean Worlds. Durham: Duke University Press.

Deonandan, Kalowatie, and Michael L. Dougherty, eds. 2016. Mining in Latin America: Critical Approaches to the New Extraction (Routledge Studies of the Extractive Industries and Sustainable Development). lst ed. London/New York: Routledge.

Descola, Philippe. 2014a. All too Human (still): A Comment on Eduardo Kohn's How Forests Think. HAU: Journal of Ethnographic Theory 4 (2): 267-273.

- 2014b. La Composition des Mondes: Entretiens avec Pierre Charbonnier. Paris: Flammarion.

- 2014c. Modes of Being and Forms of Predication. HAU: Journal of Ethnographic Theory 4 (1): 271-280.

- 2014d. The Difficult Art of Composing Worlds (and of Replying to Objections). HAU: Journal of Ethnographic Theory 4 (3): 431-443.

Descola, Philippe, and Tim Ingold. 2014. Etre au Monde. Quelle Expérience Commune? Lyon: Presses Universitaires de Lyon.

Erikson, Philippe. 1986. Altérité, tatouage et anthropophagie chez les Pano: la belliqueuse quête du soi. Journal de la Société des Américanistes 72: 185-210.

- 1999. El Sello de los Antepasados. Marcado del Cuerpo y Demarcación Etnica entre los Matis de la Amazonía. Quito: ABYA-YALA, IFEA.

Escobar, Arturo. 2016. Sentipensar con la Tierra: Las Luchas Territoriales y la Dimensión Ontológica de las Epistemologías del Sur. AIBR, Revista de Antropología Iberoamericana 11 (01): 11-32.

Fabricant, Nicole. 2013. Good Living for Whom? Bolivia's Climate Justice Movement and the Limitations of Indigenous Cosmovisions. Latin American and Caribbean Ethnic Studies, Special Issue: The Politics of Indigeneity in Bolivia 8 (2): 159-178.

Fausto, Carlos. 2012 [2001]. Warfare and Shamanism in Amazonia. Cambridge: Cambridge University Press.

Fischer, Michael. 2014. The Lightness of Existence and the Origami of 'French' Anthropology: Latour, Descola, Viveiros de Castro, Meillassoux, and Their So-Called Ontological Turn. HAU: Journal of Ethnographic Theory 4 (1): 331-355.

Fortis, Paolo. 2014. Artefacts and Bodies Among Kuna People from Panamá. In Making and Growing. Anthropological Studies of Organisms and Artefacts, ed. Elizabeth Hallam and Tim Ingold. Farnham: Ashgate Publishing. 
Franklin, Sarah. 2017. Situated Apprehensions: A Comment on Ashley Lebner's 'Interpreting Strathern's “Unconscious” Critique of Ontology'. Social Anthropology 25 (2): 228-229.

Fraser, Nancy. 2012. Feminism, Capitalism, and the Cunning of History: An Introduction. FMSH-WP-2012-17.

Friedman, Jonathan. 1999. Indigenous Struggles and the Discreet Charm of the Bourgeoisie. The Australian Journal of Anthropology 10 (1): 1-14.

Gago, Verónica. 2015. La razón neoliberal: Economías barrocas y pragmática popular. Buenos Aires: Tinta Limón.

García, María Elena. 2005. Making Indigenous Citizens: Identities, Education, and Multicultural Development in Peru. Palo Alto: Stanford University Press.

- 2008. Introduction: Indigenous Encounters in Contemporary Peru. Latin American and Caribbean Studies 3 (3): 217-226.

Goldstein, Daniel M. 2016. Owners of the Sidewalk: Security and Survival in the Informal City. Durham/London: Duke University Press.

Gordillo, Gastón. 2014. Rubble: The Afterlife of Destruction. Durham/London: Duke University Press.

Gudynas, Eduardo. 2011. Debates sobre el desarrollo y sus alternativas en América Latina: una breve guía heterodoxa. In Más allá del dessarrollo, ed. Grupo Permanente de Trabajo sobre Alternativas al Desarrollo. Quito: Abya Yala y Fundación Rosa Luxemburg.

- 2018. Extractivismos y corrupción en América del Sur. Estructuras, dinámicas y tendencias en una íntima relación. Revista de Ciencias Sociales y Humanas 10 (10): 73-87.

Gutiérrez, Manuel. 2001. La Perspectiva de los Súbditos Indios del Emperador. In De la Unión de Coronas al Imperio de Carlos V, ed. E. Belenguer. Madrid: Sociedad Estatal para la Conmemoración de los Centenarios de Felipe II y Carlos V, Volumen II.

Hage, Ghassan. 2012. Critical Anthropological Thought and the Radical Political Imaginary Today. Critique of Anthropology 32 (3): 285-308.

Halbmayer, Ernst. 2012. Debating Animism, Perspectivism and the Construction of Ontologies. Indiana 29: 9-23.

Haraway, Donna. 2008. When Species Meet. Minneapolis: University of Minnesota Press.

. 2016. Staying with the Trouble: Making Kin in the Chthulucene. Durham: Duke University Press.

Haraway, Donna, Noboru Ishikawa, Scott F. Gilbert, Kenneth Olwig, Anna L. Tsing, and Nils Bubandt. 2016. Anthropologists are Talking-About the Anthropocene. Ethnos 81 (3): 535-564.

Harris, Olivia. 2000. To Make the Earth Bear Fruit: Ethnographic Essays on Fertility, Work and Gender in Highland Bolivia. London: Institute of Latin American Studies. 
Harvey, David. 2007. Neoliberalism as Creative Destruction. The Annals of the American Academy of Political and Social Science 610 (1): 21-44.

Harvey, Penny, and Hannah Knox. 2015. Roads: An Anthropology of Infrastructure and Expertise. Ithaca: Cornell University Press.

Hasland, Paul A., and Pablo Heidrich, eds. 2016. The Political Economy of Natural Resources and Development: From Neoliberalism to Resource Nationalism (Routledge Studies in Development Economics, lst ed.). London/New York: Routledge.

HAU: Journal of Ethnographic Theory. n.d. HAU: Journal of Ethnographic Theory. https://www.haujournal.org/index.php/hau/index. Accessed 22 June 2017.

Henare, Amiria, Martin Holbraad, and Sari Wastell, eds. 2007. Thinking through Things: Theorising Artefacts Ethnographically. London: Routledge.

Heywood, Paolo. 2012. Anthropology and What There Is: Reflections on 'Ontology'. The Cambridge Journal of Anthropology 30 (1): 143-151.

High, Casey. 2015. Victims and Warriors: Violence, History, and Memory in Amazonia. Champaign: University of Illinois Press.

Holbraad, Martin. 2009. Ontology, Ethnography, Archaeology: An Afterword on the Ontography of Things. Cambridge Archaeological Journal 19 (3): 431-441.

- 2012. Truth in Motion: The Recursive Anthropology of Cuban Divination. Chicago/London: The University of Chicago Press.

- 2014. Tres Provocaciones Ontológicas. Ankulegi 18: 127-139.

Holbraad, Martin, and Morten Axel Pedersen. 2017. The Ontological Turn: An Anthropological Exposition. Cambridge: Cambridge University Press.

Hornborg, Alf. 2006. Knowledge of Persons, Knowledge of Things: Animism, Fetishism, and Objectivism as Strategies for Knowing (or not Knowing) the World. Ethnos 71 (1): 21-32.

Howe, Cymene. 2015. Latin America in the Anthropocene: Energy Transitions and Climate Change Mitigations. The Journal of Latin American and Caribbean Anthropology 20 (2): 231-241.

Ingold, Tim. 2000. The Perception of the Environment: Essays on Livelibood, Dwelling and Skill. London: Routledge.

- 2013. Making: Anthropology, Archaeology, Art and Architecture. London: Routledge.

Ingold, Tim, and Elizabeth Hallam. 2014. Making and Growing: An Introduction. In Making and Growing: Anthropological Studies of Organisms and Artefacts, ed. Elizabeth Hallam and Tim Ingold. Farnham: Ashgate Publishing.

Jalbert, Kirk, Anna Willow, David Casagrande, and Stephanie Paladino, eds. 2017. ExtrACTION: Impacts, Engagements, and Alternative Futures. London/New York: Routledge.

Kapfhammer, Wolfgang. 2012. Amazonian Pain: Indigenous Ontologies and Western Eco-Spirituality. Indiana 29: 145-169. 
Kawa, Nicholas. 2016. Amazonia in the Anthropocene. Austin: University of Texas Press.

Keane, Webb. 2013. Ontologies, Anthropologies and Ethical Life. Comment on Lloyd, G. E. R. 2012. Being, Humanity, and Understanding. Oxford: Oxford University Press. Hau: Journal of Ethnographic Theory 3(1): 186-191.

Kelly, John. 2014. The Ontological Turn: Where Are We? HAU: Journal of Ethnographic Theory 4 (1): 357-360.

Killick, Evan. 2014. Whose Truth Is It Anyway? A Review of Truth in Motion: The Recursive Anthropology of Cuban divination. Anthropology of this Century 9. http://aotcpress.com/articles/truth/. Accessed 19 Mar 2016.

- Perspectives on Climate Change and Its Mitigation: Ontological Wars in Amazonia. (Keynote Paper given at the Conference, Trans-Environmental Dynamics: Understanding and Debating Ontologies, Politics, and History in Latin America, LMU Munich October 2015.) https://www.academia. edu/20759277/Perspectives_on_Climate_Change_and_its_Mitigation_ Ontological_Wars_in_Amazonia. Accessed 29 Jan 2018.

Kohn, Eduardo. 2009. A Conversation with Philippe Descola. Tipiti: Journal of the Society for the Anthropology of Lowland South America 7 (2): 135-150.

- 2013. How Forests Think: Toward an Anthropology Beyond the Human. Oakland: University of California Press.

- 2015. Anthropology of Ontologies. Annual Review of Anthropology 44: $311-327$.

Latour, Bruno. 2005. Reassembling the Social: An Introduction to Actor-NetworkTheory. Oxford: Oxford University Press. $1-18$.

- 2014. Agency at the Time of the Anthropocene. New Literary History 45:

- 2015. Los Modernos, Según la Antropología. Ñ. Revista de Cultura (Clarin). http://www.revistaenie.clarin.com/ideas/Bruno-Latour-modernosantropologia_0_1295270475.html. Accessed 19 Mar 2016.

Law, John, and Marianne E. Lien. 2012. Denaturalising Nature. Public Inaugural Sawyer Seminar talk at University of California, Davis. https://www.sv.uio.no/ sai/english/research/projects/newcomers/publications/working-papersweb/denanturalisingnaturetalk2.pdf. Accessed 19 Jan 2018.

Lebner, Ashley. 2017. Interpreting Strathern's 'Unconscious' Critique of Ontology. Social Anthropology 25 (2): 221-233.

Lerner, Steve. 2010. Sacrifice Zones: The Front Lines of Toxic Chemical Exposure in the United States. Cambridge, MA: MIT Press.

Li, Fabiana. 2015. Unearthing Conflict: Corporate Mining, Activism, and Expertise in Peru. Durham: Duke University Press.

Matthes, Sebastian, and Zeljko Crncic. 2012. 'Extractivism.' InterAmerican Wiki: Terms - Concepts - Critical Perspectives. www.uni-bielefeld.de/cias/wiki/e Extractivism.html. Accessed 26 Jan 2018. 
McNeish, John-Andrew, Axel Borchgrevink, and Owen Logan, eds. 2015. Contested Powers: The Politics of Energy and Development in Latin America. London: Zed Books.

Merino, Roger. 2016. An Alternative to 'Alternative Development'?: Buen Vivir and Human Development in Andean Countries. Oxford Development Studies 44 (3): 271-286.

Mitchell, Timothy. 2011. Carbon Democracy. Political Power in the Age of Oil. London/Brooklyn: Verso.

Mol, Annemarie. 1999. Ontological Politics: A Word and Some Questions. The Sociological Review 47 (S1): 74-89.

Murray Li, Tanya. 2010. Indigeneity, Capitalism, and the Management of Dispossession. Current Anthropology 51 (3): 385-414.

Narotzky, Susana. 2010. Las antropologías hegemónicas y las antropologías del sur: el caso de España. Antípoda 11: 241-258.

Nash, June, ed. 1979. We Eat the Mines and the Mines Eat Us: Dependency and Exploitation in Bolivian Tin Mines. New York: Columbia University Press.

Neurath, Johannes. 2015. Shifting Ontologies in Huichol Ritual and Art. Anthropology and Humanism 40 (1): 58-71.

Nielsen, Axel. 2016. Home-Making Among South Andean Pastoralists. In The Archaeology of Andean Pastoralism, ed. José Capriles and Nicholas Tripcevich. Albuquerque: University of New Mexico Press.

Nixon, Rob. 2013. Slow Violence and the Environmentalism of the Poor. Cambridge, MA: Harvard University Press.

Ødegaard, Cecilie Vindal. 2010. Mobility, Markets and Indigenous Socialities: Contemporary Migration in the Peruvian Andes. Surrey: Ashgate Publishing.

- 2016. Alterity, Predation, and Questions of Representation: The Problem of the Kharisiri in the Andes. In Critical Anthropological Engagements in Human Alterity and Difference, ed. B.E. Bertelsen and S. Bendixsen. London: Palgrave Macmillan.

Orta, Andrew. 2004. Catechizing Culture. Missionaries, Aymara and the "New Evangelization". New York/Chichester: Columbia University Press.

Ortiz Rescaniere, Alejandro. 1999. El Individuo Andino, Autóctono y Cosmopolita. In Cultura y globalización, ed. Carlos Iván Degregori and Gonzalo Portocarrero. Lima: PUCP, Universidad del Pacífico, IEP.

Oyuela-Caycedo, A. 2014. Book review of Brightman, M., V. E. Grotti, and O. Ulturgasheva. 2012. Animism in Rainforest and Tundra: Personhood, Animals, Plants and Things in Contemporary Amazonia and Siberia. Bulletin of Latin American Research 33 (4): 536-537.

Pazos, Álvaro. 2006. Recensión Crítica de Philippe Descola Par-delà Nature et Culture. AIBR. Revista de Antropología Iberoamericana l (1): 186-194.

- 2007. Recensión Crítica de Tierra Adentro. Territorio Indígena y Percepción del Entorno. AIBR: Revista de Antropología Iberoamericana 2 (2): 369-377. 
Pazzarelli, Francisco. 2013. Otros-maices: trayectorias y transformaciones culinarias del maíz en Ambato (Catamarca, Noroeste Argentino). Revista Española de Antropología Americana 43 (2): 329-351.

Pedersen, Morten Axel. 2014. A Reader's Guide to the 'Ontological Turn'-Part 3. Somatosphere. http://somatosphere.net/2014/02/a-readers-guide-to-theontological-turn-part-3.html. Accessed 19 Mar 2016.

- 2017. Strathern and Ontology: An Awkward Relationship-A Comment on Lebner. Social Anthropology 25 (2): 229-230.

Piette, Albert. 2012. De l'Ontologie en Anthropologie. Paris: Berg International. Pitarch, Pedro. 2003. Infidelidades indígenas. Revista de Occidente 269: 60-76.

Platt, Tristan. 1982. The Role of the Andean Ayllu in the Reproduction of the Petty Commodity Regime in Northern Potosií (Bolivia). In Ecology and Exchange in the Andes, ed. David Lehmann. Cambridge: Cambridge University Press.

Portocarrero, Gonzalo. 1991. Sacaojos: crisis social y fantasmas coloniales. Lima: Tarea.

Postero, Nancy. 2013. Introduction: Negotiating Indigeneity. Latin American and Caribbean Ethnic Studies, Special Issue: The Politics of Indigeneity in Bolivia 8 (2): 107-121.

- 2017. The Indigenous State: Race, Politics, and Performance in Plurinational Bolivia. Oakland: University of California Press.

Povinelli, Elizabeth. 2001. Radical Worlds: The Anthropology of Incommensurability and Inconceivability. Annual Review of Anthropology 30: 319-334.

- 2012. Reclaiming Animism. E-flux 36. http://www.e-flux.com/journal/36/61245/reclaiming-animism/. Accessed 30 Jan 2018.

Ramos, Alcida Rita. 1998. Indigenism: Ethnic Politics in Brazil. Madison/London: University of Wisconsin Press.

- 2012. The Politics of Perspectivism. The Annual Review of Anthropology 41: 481-494.

Rata, Elizabeth. 1997. Global Capitalism and the Revival of Ethnic Traditionalism in New Zealand. PhD dissertation, University of Auckland.

Reed, Adam. 2016. Postscript: Taking the Ontological Turn Personally. In Critical Anthropological Engagements in Human Alterity and Difference, ed. B.E. Bertelsen and S. Bendixsen. London: Palgrave Macmillan.

Remme, Jon Henrik Ziegler. 2016. Chronically Unstable Ontology: Ontological Dynamics, Radical Alterity, and the 'Otherwise Within'. In Critical Anthropological Engagements in Human Alterity and Difference, ed. B.E. Bertelsen and S. Bendixsens. London: Palgrave Macmillan.

Rival, Laura. 2012a. Animism and the Meanings of Life: Reflections from Amazonia. In Animism in Rainforest and Tundra: Personhood, Animals, Plants and Things in Contemporary Amazonia and Siberia, ed. M. Brightman, V. Grotti, and O. Ulturgasheva. London: Berghahn Books. 
2012b. The Materiality of Life: Revisiting the Anthropology of Nature in Amazonia. Indiana 29: 127-143.

Rivera Andía, Juan Javier. 2005a. Killing What You Love: An Andean Cattle Branding Ritual and the Dilemmas of Modernity. Journal of Anthropological Research 61 (2): 129-156.

- 2005b. Territorio e identidad en los Andes. Concepciones populares en torno a las zonas ecológicas altas en la sierra de Lima. Revista de Dialectología $y$ Tradiciones Populares 40 (2): 55-76.

- 2006. Mitología en los Andes. In Mitologías Amerindias, ed. Alejandro Ortiz Rescaniere. Madrid: Trotta.

-2008. Apuntes sobre la alteridad constituyente en los Andes. Ambivalencias Rituales y Lingüísticas sobre un Espacio Imaginario. Revista Española de Antropología Americana 38 (1): 191-215.

- 2015. Amerindian Misfortunes: Ethnographies of South American Rituals and Cosmologies on Danger, Illness, and Evil. Indiana 32: 9-22.

Salmond, Amiria J.M. 2014. Transforming Translations (Part 2): Addressing Ontological Alterity. HAU: Journal of Ethnographic Theory 4 (1): 155-187.

Santos-Granero, Fernando. 2009. Introduction: Amerindian Constructional Views of the World. In The Occult Life of Things. Native Amazonian Theories of Materiality and Personhood, ed. Fernando Santos-Granero. Tucson: University of Arizona Press.

Schavelzon, Salvador. 2016. La política indígena y la investigación en Bolivia. Revista de Antropologia 59 (3): 115-149.

Scott, Michael W. 2013. The Anthropology of Ontology (Religious Science?). Journal of the Royal Anthropological Institute (N.S.) 19 (4): 859-872.

Shellenberger, Michael, and Ted Nordhaus. 2011. The Long Death of Environmentalism. The Breakthrough. http://thebreakthrough.org/archive/ the_long_death_of_environmenta. Accessed 27 Jan 2018.

Stengers, Isabelle. 1996. Cosmopolitiques: T1. La guerre des sciences. Paris: La Découverte.

- 2005. The Cosmopolitical Proposal. In Making Things Public: Atmospheres of Democracy, ed. Bruno Latour and Peter Weibel. Cambridge, MA: MIT Press.

- 2012. Reclaiming Animism. E-flux 36. http://www.e-flux.com/ journal/36/61245/reclaiming-animism/. Accessed 18 Jan 2018.

Steur, Luisa. 2014. Indigeneity and Precariousness: Ontological Criticism or Dialectical Force? FocaalBlog, July 17. www.focaalblog.com/2014/07/17/ indigeneity-and-precariousness-ontological-criticism-or-dialectical-force-byluisasteur. Accessed 9 Sept 2017.

Strathern, Marilyn. 2004. Partial Connections. New York: AltaMira.

Svampa, Maristella. 2013. 'Consenso de los Commodities' y lenguajes de valoración en América Latina. Nueva Sociedad 244: 30-46. 
Todd, Zoe. 2016. An Indigenous Feminist's Take on the Ontological Turn: 'Ontology' is Just Another Word for Colonialism. Journal of Historical Sociology 29 (1): 4-22.

Tsing, Anna Lowenhaupt. 2015. The Mushroom at the End of the World. Princeton: Princeton University Press.

Turner, Terry S. 2009. The Crisis of Late Structuralism: Perspectivism and Animism: Rethinking Culture, Nature, Spirit, and Bodiliness. Tipiti: Journal of the Society for the Anthropology of Lowland South America 7 (1): 3-40.

Tylor, E. 1871. Primitive Culture: Researches into the Development of Mythology, Philosophy, Religion, Art, and Custom. London: J. Murray.

Veltmeyer, Henry, and James Petras, eds. 2014. The New Extractivism: A PostNeoliberal Development Model or Imperialism of the Twenty-First Century? London: Zed Books.

Vigh, Henrik Erdman, and David Brehm Sausdal. 2014. From Essence Back to Existence: Anthropology Beyond the Ontological Turn. Anthropological Theory 14 (1): 49-73.

Viveiros de Castro, Eduardo. 1992. From the Enemy's Point of View: Humanity and Divinity in an Amazonian Society. Chicago: University of Chicago Press.

- 1998. Cosmological Deixis and Amerindian Perspectivism. The Journal of the Royal Anthropological Institute 4 (3): 469-488.

- 1999. Comments to "Animism Revisited: Personhood, Environment, and Relational Epistemology”. Current Anthropology 40: 79-80.

- 2004a. Exchanging Perspectives: The Transformation of Objects into Subjects in Amerindian Ontologies. Common Knowledge 10 (3): 463-484.

- 2004b. Perspectival Anthropology and the Method of Controlled Equivocation. Tipiti: Journal of the Society for the Anthropology of Lowland South America 2 (1): 3-22.

- 2011. The Inconstancy of the Indian Soul: The Encounter of Catholics and Cannibals in 16th Century Brazil. Chicago: Prickly Paradigm Press.

- 2015a. The Relative Native: Essays on Indigenous Conceptual Worlds. Chicago: Hau Books.

- 2015b. Who Is Afraid of the Ontological Wolf? Some Comments on an Ongoing Anthropological Debate. The Cambridge Journal of Anthropology 33 (1): 2-17.

Wade, Peter. 2017. Degrees of Mixture, Degrees of Freedom: Genomics, Multiculturalism, and Race in Latin America. Durham: Duke University Press.

Wardle, Huon, and Justin Shaffner, eds. 2017. Cosmopolitics: Collected Papers of the Open Anthropology Cooperative. Vol. I. St Andrews: Open Anthropology Cooperative Press.

Warren, Kay B., and Jean E. Jackson. 2002. Indigenous Movements, SelfRepresentation, and the State in Latin America. Austin: University of Texas Press. 
Willerslev, Rane. 2007. Soul Hunters: Hunting, Animism, and Personhood among the Siberian Yukaghirs. Berkeley: University of California Press.

2013. Taking Animism Seriously, but Perhaps Not Too Seriously? Religion and Society: Advances in Research 4 (1): 41-57.

Wolf, Eric. 1957. Closed Corporate Peasant Communities in Mesoamerica and Central Java. Southwestern Journal of Anthropology 13 (1): 1-18.

Open Access This chapter is licensed under the terms of the Creative Commons Attribution 4.0 International License (http://creativecommons.org/licenses/ by $/ 4.0 /)$, which permits use, sharing, adaptation, distribution and reproduction in any medium or format, as long as you give appropriate credit to the original author(s) and the source, provide a link to the Creative Commons license and indicate if changes were made.

The images or other third party material in this chapter are included in the chapter's Creative Commons license, unless indicated otherwise in a credit line to the material. If material is not included in the chapter's Creative Commons license and your intended use is not permitted by statutory regulation or exceeds the permitted use, you will need to obtain permission directly from the copyright holder.

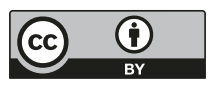


Flows, Wealth, and Access 


\title{
Controlling Abandoned Oil Installations: Ruination and Ownership in Northern Peruvian Amazonia
}

\author{
Maria A. Guzmán-Gallegos
}

\section{INTRODUCTION}

Oil extraction has led to severe environmental degradation in Loreto in Northern Peruvian Amazonia and has created landscapes of scattered debris. It started in 1972 when the Peruvian government granted concessions of oil field $1 \mathrm{AB} / 192$ to the American Occidental Petroleum Corporation (OXY) and oil field 8-8X to Peru's state-owned Petroperú (La Torre 1998). In spite of changes in the corporations operating these oil fields, destructive environmental practices have characterised oil extraction here for four decades. As early as 1984, the National Bureau for the Assessment of Natural Resources (ONERN) declared oil field 1AB/192 one of Peru's most polluted areas (ONERN 1984). Up to 2009, Pluspetrol—which won the bid for Block 8 and acquired rights to oil field $1 \mathrm{AB} / 192$ in 2000 - continued discharging toxic effluents with a high

M. A. Guzmán-Gallegos $(\bowtie)$

University of Oslo, Oslo, Norway

e-mail: m.a.guzman-gallegos@sai.uio.no

(C) The Author(s) 2019

C. Vindal Ødegaard, J. J. Rivera Andía (eds.), Indigenous Life

Projects and Extractivism, Approaches to Social Inequality and

Difference, https://doi.org/10.1007/978-3-319-93435-8_2 
content of heavy metals and hydrocarbons directly into soil and water bodies (Yusta-García et al. 2016; Lu 2009; Campanario and Doyle 2017).

These practices have left many sites contaminated and unproductive oil installations in ruins. The numbers of such sites and installations, however, are contested. Oil operators have not registered them in environmental management plans which go to the authorities, and the environmental authorities do not have independent registers. Only in oil field $1 \mathrm{AB} / 192$, 249 oil wells have been drilled. Of these, 76 have been declared temporarily abandoned, while 40 are permanently abandoned ( $\mathrm{Lu} 2009$; Campanario and Doyle 2017). ${ }^{1}$ Additionally, there are the ruins of other types of installations that have been dismantled earlier, such as a refinery or a harbour operated by OXY until the mid-1980s, ruins which often have not been counted. In 2013-14, increasing conflict and political mobilisation forced environmental and health authorities to carry out a series of monitoring activities with the participation of villagers and local environmental monitors. Taking the presence of hydrocarbon residues as the defining criterion, the Agency for Environmental Assessment and Control (OEFA) documented the existence of 92 contaminated sites, including some abandoned installations, which had not been declared by Pluspetrol. ${ }^{2}$ However, the indigenous organisations of oil fields $1 \mathrm{AB} / 192$ and 8 claimed that there were more than 2000, including dumps of toxic waste (Campanario and Doyle 2017). ${ }^{3}$

On the one hand, this chapter is concerned with the sheer materiality of the leftovers of extraction in the Upper Tigre River. On the other hand, it addresses the diverse and changing ways in which the Kichwa people in the Upper Tigre River have related to this debris in their daily lives. ${ }^{4} \mathrm{My}$ aim is twofold: I acknowledge and build upon the insights of literature on environmental justice that critically examine the unequal distribution of harmwhich invariably hits marginalised populations the hardest (Bohme 2014; Kuletz 1998). However, I explore the Kichwa people's claims of ownership of different types of oil debris, and suggest that they also express other ways of conceiving and enacting ownership, and, thereby, of the relation established between subjects and objects. I argue that these understandings and world-making practices, which could be called 'ontological', are central to how the Kichwa relate to oil production and its leftovers. These are infrequently discussed in literature dealing with environmental justice and extraction (Arellano Yanguas 2011; Bebbington and Bury 2013). My second aim, as Krøjer's chapter in this book does, is to question and take a step beyond the critique of the ontological turn in anthropology, which tends 
to assume that an interest in ontological questions is, almost per definition, essentialist (Cepek 2016; Vigh and Sausdal 2014). While I show how the Peruvian state's enactments of dominant models of property do make worlds as Blomley (2013) aptly puts it, I contend that the Kichwa people of the Upper Tigre River contest the state and corporate colonial dismissal of their indigenous ways of life and of existing asymmetries, precisely by enacting different forms of ownership, including state-promoted forms. In my analysis, I bring two distinct theoretical frameworks into dialogue and tension. By focusing on waste, rubble, and ruination, the first framework critically reviews the persistent effects of imperial and colonial formations that continue constituting some places as sacrifice zones (zones that are spatially destroyed and environmentally impaired) and some people as disposable (Stoler 2013). The second framework focuses on indigenous understandings and practices regarding ownership, that is, on different and divergent ways of establishing rights over things and persons (Brightman's chapter in this book, Brightman 2010; Brightman et al. 2016; SantosGranero 2009b).

The chapter begins with a brief presentation of the two analytical frameworks. The second section is an account of the different processes of placemaking and of military spatial reorganisation and relocation that preceded oil production. In the third section, I discuss how people sought to appropriate oil debris to counteract corporate stinginess and exclusionary practices. The concluding sections explore how different understandings and enactments of ownership are put into play to contest ruination and exclusion. ${ }^{5}$

\section{Ruination AND OWNERSHIP}

Ruins, rubble, and ruination are central concepts in the works of Gordillo (2014) and Stoler (2008). A ruin, they suggest, is in itself an ambiguous concept. As commonly used, 'ruins' evokes a sense of large-scale structures abandoned and grown over, of the decay of what once was grandiose, to give space to something new. However, 'ruins' also refers to 'the material sedimentation of destruction' (Gordillo 2014: 10) and to 'what people are left with' (Stoler 2008: 194). In my analysis, I use waste, in addition to rubber and ruination, to approach the leftovers of oil production. These leftovers are heterogeneous; they include toxic waste-which leaked into or was disposed of in water bodies or which accumulated on outdoor dumps - and the corroding infrastructure left behind when oil 
findings were no longer considered profitable or when oil installations were dismantled. The ways in which people of the Upper Tigre River relate to the different types of oil debris are ambiguous in several ways. For them, oil debris materialises the destruction of previous places and the colonial disregard of their existence and their ways of life. At the same time, oil waste and rubble are the material expression of thwarted promises of progress.

The accumulation of toxic waste, rubble, and ruination are part of political projects that render certain people as disposable and certain places as sacrifice zones. Yet waste, rubble, and ruination can be turned into sites of contestation, of alternative interpretations, and practices that animate new possibilities (Stoler 2008). As we shall see, they may also be transformed in such a way that they challenge exclusion, state abandonment, and state control. In this chapter, I argue that the emergence of such possibilities is linked, in Peruvian Amazonia as elsewhere in Latin America, to claims of territorial control and ownership. This is not surprising. The spatial reorganisation which colonisation brings about has been at the core of colonial regimes. The denial of different forms of ownership, especially of land, has been a premise for establishing the idea of property as private and exclusive (Brightman et al. 2016). Hence, territorial control, ownership, and property have been central issues to indigenous struggles since colonial times (Rivera Cusicanqui 1990, 2010).

As I show, the people of the Upper Tigre River are claiming ownership over abandoned installations, such as oil wells or the corroding grids of oil pipelines of what was once a refinery. I argue that their claims rest on divergent but coexisting understandings and enactments of ownership which are common in native Amazonian ${ }^{6}$ contexts, and which also are part of and a response to colonialism and capitalist expansion. In my analysis, I build on recent anthropological work from Amazonia, which explores how ownership is conceived and enacted in contexts in which a divide between persons and things is, at its best, fuzzy, and cannot be assumed.

It has been extensively documented that indigenous peoples in this region endow objects with various degrees of agency, subjectivity, and as having their own life (Viveiros de Castro 2004; Guzmán-Gallegos 2009; Santos-Granero 2009a; Walker 2012; Berjón and Cadenas 2018). Objects are also thought of as personified objectifications of social relations, that is, objects appear not just as things but as the materialisation of the relational constitution of persons. For instance, natural objects such as swiddens materialise the relation between spouses and constitute them as such; 
manioc plants materialise the knowledge and bodily abilities of the female owners of the plants that enable the women to plant, maintain, and nurture a rich garden. Plants materialise also the relations, which a woman considers herself to be part and product of. Moreover, the relational constitution of persons entails the co-constitution of persons and objects. Manioc plants, which are particularly important in the process of becoming a proper woman, are carnally associated with the women who create them. If a woman dies, her plants will also die, as nobody will take care of her garden (Descola 1994; Guzmán-Gallegos 1997; Coelho do Souza 2016).

While current hegemonic Western assumptions constitute and perform property as individual and permanent (Blomley 2005, 2013), ownership in native Amazonia is conceived of and enacted as a process of appropriation. Continuous acts of care, of renewal, and of creative transformation are central, and those who nurture and care have rights in, and control over, what is nurtured and cared for (Brightman et al. 2016; Fausto 2012; Guzmán-Gallegos 2015; Santos-Granero 2009b; Walker 2012). Ownership is further subject to abandoning and forgetting. When the owner no longer takes care of it, cannot transform it into something else, or when something once owned is abandoned and forgotten, ownership may cease. This is the case, for example, with forests which have been transformed into swiddens and which are owned by those who cultivate and take care of them. Swiddens that are abandoned may turn into forests and may be forgotten; the traces of those who once owned the swidden disappear gradually, together with the rights they once had. Abandoned places may be subject to new processes of appropriation (Brightman 2010; Guzmán-Gallegos 2015; Brightman et al. 2016; Viegas 2016).

Dominant legal regimes constitute property of land as a fixed enclosure and a natural object that can be alienated. However, native Amazonians conceive of land, including forests and water bodies, as worlds that humans inhabit together with other nonhuman beings. Indeed, according to a common perception, reality is made of different worlds. As Fausto (2012) aptly suggests, these are worlds of owners. For the villagers of the Upper Tigre River, for instance, the rivers are the world of the water people (yakuruna) and the forests the world of the forest people (sacharuna). The swirling rivers are places inhabited by the black boa, the owner and mother of fish. In the forests, a man is the owner of the forest animals. It is up to the mother and owner of fish and the owner of forest animals, respectively, to let the villagers navigate the rivers and walk in the forests safely. As caregivers of fish and game, the owners can decide when the villagers may catch 
fish and obtain game. These perceptions and practices are not valid in national legal frameworks nor from the perspective of state representatives. But neither do the people of the Upper Tigre River make them explicitly relevant in their claims and demands of the state. However, along with many other people in Amazonia, they are engaged in struggles for retaining ownership and control of the places they inhabit. They do so by enacting property on both the terms of the state and according to their own practices.

The formalisation of ownership often raises practical and epistemological questions. As Brightman et al. (2016) suggest, even when native conceptions and practices are taken into account, much may be lost in the process of translation. I contend, however, that the formalisation of ownership of land, of forests - and as discussed here, of oil infrastructuremultiplies the object owned. It does so in such a way that the owned object also materialises and personifies the relations the people of the Upper Tigre River have with the state and with other non-indigenous actors such as oil companies and merchants. I suggest that this multiplicity hinges on common Amazonian perceptions, according to which no thing is only one but rather is 'both and'. This means that what an entity is (human or nonhuman) depends on the relations from which it emerges (Viveiros de Castro 2010: 40; de la Cadena 2015). Second, this multiplicity requires that other ways of conceiving and enacting ownership are neither annulled nor replaced. The ownership of such objects entails not only care but also legal titling. This multiplicity is, I suggest, part of people's response to the colonial dismissal of their ways of life.

\section{Placemaking and Colonial Relocations}

The Upper Tigre River crosses oil field $1 \mathrm{AB} / 192$, located at the borderlands of Ecuador and Peru, in Northern Peruvian Amazonia. The inhabitants of this area trace their origins to Kichwa villages located northward in the Ecuadorian Amazonia and to Achuar and Quechua villages located eastward in the Peruvian Amazonia. They also include in their origins the Spanish-speaking mestizo traders who came from other Amazonian towns, married, and settled in the area. These extensive kinship, intermarriage, and trade networks were abruptly transformed in 1941 when the war between Ecuador and Peru broke out and the frontier line was moved 300 kilometres north; new forms of spatial occupation were introduced, and asymmetrical patronage relations were reinforced. 
During the 1940s and early 1950s, the Peruvian military, often combining physical violence and existing patronage bonds, relocated Kichwa villages and families who lived dispersed along tributaries of the Tigre River. This strategy, designed to gain military control over these areas and their indigenous inhabitants who were considered ecuachos (people from Ecuador), meant that the interfluvial occupation of space common in those days, was largely replaced by a riverine occupation which also facilitated a stronger inclusion of Kichwa settlements into the debt patronage system. The military then appointed Spanish-speaking mestizo patrones, usually traders, as authorities of the new villages; they gained control over indigenous labour and their products through permanent indebtedness. The patrones provided Kichwa families with desired goods, such as soap, clothes, shotguns, and cartridges, in advance, which the Kichwa paid for by selling hardwood and pelts. The villagers consider these asymmetrical exchanges as acts that demonstrated the patrones' caring intentions and as acts of exploitation. According to Don Osvaldo, a man in his 70s who told me the history of his family and his village, 'Some patrons were better than the others and liked to share, and cared for their people. However, when we sold things to them, the hand of the patron was his weighing scale, no wonder that we could never get rid of our debts.'

A new form of spatial occupation, based on the negation of existing forms of territorial control and placemaking, started when oil extraction activities began in the early 1970s, simultaneously expanding existing frontiers of extraction. The military and the exploratory companies contracted by OXY displaced families from their houses and cultivated areas, arguing that the riverbanks, swiddens, and forests were unoccupied land belonging to the state. This destruction of orchards and forests to clear the sites for oil installations entailed the colonial dismissal of local ways of life and, according to the villagers, the oblivion of those who were the owners of those places. Magdalena, a woman whose family was displaced, said to me: 'We were living there but they said that those places were uninhabited. They made us run away from our own houses, and we got nothing for all our work and suffering in making swiddens, nothing was left.' In other words, the work and effort which the families had put into building houses, into transforming forests into swiddens, and into the daily and arduous caring of swiddens was ignored, and the traces of their lives were destroyed.

Oil installations became points of attraction and hope-and of exclusion. Wanting to take part in the promises of wealth and development, 
Kichwa people relocated their villages to be closer to productive oil installations. They benefitted partially and indirectly from oil extraction through the expansion of existing trade, which reached new peaks with the increased presence of mestizo merchants and loggers, and through the migration of male mestizo workers employed by the exploratory and oil-producing companies. During exploratory activities, Kichwa men worked as trocheros clearing paths so the workers of exploratory companies could lay seismic lines and as mitayeros providing game for them. When oil production started, oil operators did not hire indigenous people. So the Kichwa men continued working as providers of game and significantly increased their logging of valued hardwood such as cedar and mahogany. As in earlier times, however, merchants associated with oil transportation took the biggest share. Villagers and missionaries can still recall the unprecedented amounts of hardwood that were shipped away in the same boats that transported crude oil.

The disregard and negation of the existence of indigenous families; the destruction of swiddens, houses, and forests; and the increasing trade that followed oil production led to severe degradation of forests and to the near extinction of some animal species such as ocelots and turtles. This absence of valued trees and animal species came together with the continuous presence of debris caused by oil production practices.

\section{Corporate Stinginess and Exclusion: Gathering} and Appropriating Oil Debris

Exclusion, corporate stinginess, and ways of contesting it have been recurrent themes in the conversations and memories of the people of the Upper Tigre River, as illustrated in the account of Arturo from the village of Marsella. The village was founded in the 1950s after a forced relocation of families who had been living dispersed along the Piedra Lisa River. When exploratory oil activities started in the 1970s, Marsella was again relocated to the opposite side of the river where OXY was to build a refinery. Once it was built, OXY had a camp within the refinery of cement houses with electricity and access to clean water for the American engineers and the Peruvian Spanish-speaking workers. OXY's American engineers, said Arturo, were stingy and did not want to share. According to Arturo, they were so stingy that they preferred to throw away the food they did not eat and the things they no longer used rather than give these to the villagers. 
Apart from the merchants, who could afford kerosene and gasoline, the native people of Marsella were left without electricity but with the leftovers of extraction. As this section shows, appropriating the debris produced by oil extraction practices became a way for the villagers to counteract corporate stinginess and exclusion.

Continuous oil spills, leakages, and toxic waste characterised oil production in oil fields $1 \mathrm{AB} / 192$ and 8/8X. Residues of crude oil were found in soils and water bodies. Crude oil leaked from different sources: from vessels transporting it to harbours in Saramurillo and Iquitos, from oil pipelines, from oil wells, from open mud pits, and from small streams in which oil debris accumulated. Hundreds of old containers of toxic thinners piled up and corroded outdoors. In oil field $\mathrm{lAB} / 192$, toxic effluents with a high content of barium, chloride, hydrocarbons, and oil grease were frequently discharged directly into soils, rivers, and streams, without any treatment ( $\mathrm{Lu} 2009$ ).

Although the villagers of the Upper Tigre River were aware that oil spills and leakages affected aquatic and animal life, they also considered oil spills as a way to appropriate some of the wealth that oil workers enjoyed. When crude oil leaked from transporting vessels because they had collided - either with each other or with tree trunks dragged by the riverwomen, youngsters, and children waded into the greasy waters to gather the oil. With their bare hands, they filled small bottles with oil, which they used for making small burners to get light in the evenings. Old containers, regardless of the toxicity of their contents, were also desired objects that people sought to own. In their view, these were part of the wealth that the OXY engineers did not want to share. Parents sent their children to see if they could get some discarded containers from the Peruvian camp workers, who often gave them away in exchange for game or plantains-or, if there were no workers, the children simply took them. As the villagers explained to me on different occasions, they made something new from the disregarded containers. Indeed, they were used as stoves to cook food, as bathtubs for small children, as trays to make manioc beer or manioc powder, or to store water. Acts of transformation and appropriation of the abandoned containers could, however, have dangerous consequences. On several occasions, women who split old containers of toxic thinners became seriously sick or died. A high school director, who often helped these women, argued that people could not read the warnings written in English on the containers, which detailed how dangerous its contents were, and recommended destroying the containers immediately after use. 
These understandings of oil debris both as materialisation of corporate wealth and stinginess, and as something that could be reworked and thereby appropriated, came to coexist with other notions and practices related to oil debris. As the result of political mobilisation and the approval of new laws and regulations, oil debris gradually became the materialisation of the state's and corporations' careless production of rubble and ruination. For the people of the Upper Tigre River, it has become vital to try to gain control over this rubble as a way to stop ruination, as the cases of Vista Alegre and Marsella show.

\section{Hindering the Killing of a Well 7 : The Negation of Corporate Ruination}

Vista Alegre is located at the edges of oil field $1 \mathrm{AB} / 192$. It is one of the villages that participated in the strikes of 2015 when the villagers of the Upper Tigre Rive blocked the passage of all vessels, including those bringing food to the oil workers who were staying in current oil-producing installations located further north. The strikes were part of the ongoing social mobilisation that demanded state and corporate recognition of severe oil contamination in oil field $1 \mathrm{AB} / 192$ and to oblige the state to take action (Guzmán-Gallegos 2017a). In 2016, in Vista Alegre, three environmental monitors and I decided to visit the old leaking oil well that had been central to their demands. When we arrived, I was surprised by the mixed debris on the site and the explanation I was given. The corroded and leaking oil well, located in the middle of an aguajal, ${ }^{8}$ was enclosed by a newly built wooden platform. On another platform was a brand new cement mixer and a pump surrounded by the ruins of what had been a temporary camp, with the remains of walls and roofs, heaps of canned food and beverages, and piles of fairly new industrial metal tanks.

Miguel told me that this oil well, located within Vista Alegre's communal lands, was drilled in the late 1970s and was closed defectively in the 1980s. Oil and production water had always leaked from this well into the stream running nearby. However, Pluspetrol did not know of the existence of this oil well, or, Miguel believed, most probably, the company did not want to acknowledge its existence. Therefore, the villagers were the only ones who could show the environmental authorities where the well was and help them to document the condition of the surroundings. Miguel explained that for many years, this had been an overgrown area that the villagers of 
Vista Alegre cleared each year when they came to the site to celebrate Carnival. Miguel stressed that the periodical clearings testified that the people of Vista Alegre had never forgotten the existence of the well.

More than three decades later, in 2014, the Peruvian authorities declared this oil well a contaminated site to be remediated and instructed Pluspetrol to compensate the people living close to the well. Pluspetrol cleared this site and installed the cement mixer and pump to seal the well and clean up the area, while starting compensation negotiations with the villagers of Vista Alegre. Based on an estimate of the destroyed aguaje palms (Mauritia flexuosa), they offered the villagers USD 3600 to be divided among all the families of Vista Alegre and of Remanentes, a neighbouring village. People considered this amount outrageous and referred to the high death toll that had affected Vista Alegre in the early 1990s when more than 50 adults and children had died. At the time, some villagers believed that so much death was related to continuous oil spills, thinners, and effluents discharged into a lake where they used to fish (GuzmánGallegos 2017b). They wanted the health authorities to investigate, but the authorities never came to the Upper Tigre River. Moreover, the engineers employed to seal the well told the villagers that once they had poured cement into the well, it would be impossible to pump oil again. As Venancio, one of the village's environmental monitors, vehemently explained to me, Pluspetrol was planning to kill the well. Taking into account that the well was in Vista Alegre's lands, and that the operator was not willing to take responsibility for the deaths of their children, the villagers of Vista Alegre decided to stop all sealing operations. They preferred to have control of the leaking well and keep it as it was. Ownership and the future of the abandoned oil well became an issue of fierce contention.

The demands of Vista Alegre's villagers were built upon notions of care and ownership common in Amazonian Kichwa areas (Guzmán-Gallegos 2015). Whenever the villagers spoke about the corroded oil well, they pointed out how they had taken care of it each year, how they visited the site, cleared it, and knew where the oil well was. It was true, as Pluspetrol alleged, that it was not a cultivated area-but, they said, nothing would grow there anyway. They could not hunt since game was scarce; owing to the lack of fruit, the monkeys no longer came. As a consequence of their actions of clearing, and not forgetting, the villagers of Vista Alegre claimed ownership of the oil well while excluding the people of Remanentes as owners. After the people who were currently living in Remanentes separated from Vista Alegre and formed a new village, they had not participated in any clearing, the villagers of Vista Alegre alleged. Further, they 
interpreted the compensation amount Pluspetrol offered as a manifestation of corporate stinginess and state disregard of their suffering. They insisted that the old oil well was only one of a wider infrastructure of abandoned oil wells, which had ruined several of the water bodies they depended upon. They also brought to the fore the unacknowledged deaths of their children in the 1990s.

The villagers' claims were, in addition, based on understandings and enactments of property framed by Peru's Native Communities Law. The Vista Alegre villagers asserted that the corroded well was their exclusive property because it was located within their titled community lands. Moreover, the well was one of the many abandoned oil installations that had to be accounted for by Pluspetrol's environmental managing instruments. Given their experiences of displacement and state and corporate negation of their existence and their territorial occupation, the villagers considered the current Native Communities Law to be vitally important. This law acknowledges the existence of indigenous peoples in the Peruvian Amazonia and grants them ownership and territorial rights to at least some of the lands and forests they inhabit and use. The Law of Native Communities and the Promotion of Agriculture in the Rainforest and Edge of Rainforest Regions No. 20653-passed in 1974 and replaced in 1978 by the Native Communities Law No. 21175-was not known in the villages of the Upper Tigre River until the early 1990s.9 The villagers recalled how a delegate of AIDESEP (Interethnic Association for the Development of the Peruvian Rainforest) had visited all the villages of the Upper Tigre River between 1989 and 1990 and had informed them about this law. He said that if people recognised themselves as natives, they could demand that the state recognise the areas they occupy as native community lands. Most of the villagers of the Upper Tigre River then organised assemblies and decided to recognise themselves as native communities. Since 1991 and up to 2010, the villagers of the Upper Tigre River have demanded state recognition of their villages as native communities and the titling of their lands (Guzmán-Gallegos 2017b).

For the people of the Upper Tigre River, this titling means that the state and the oil corporations can no longer negate their existence and behave as if these lands are uninhabited. It also implies that the corporations cannot destroy forests, soils, and rivers, with the same impunity as before. As the villagers said, the state and the corporations have to acknowledge that these lands have owners. As such, the authorities are now forced to relate to their demands and cannot easily disregard their 
suffering. The titling of lands entails more than state and corporate recognition. From the point of view of the inhabitants of the Upper Tigre River, ownership entails exclusive rights to what one has taken care of and transformed and to what the state has titled. Thus, owned land becomes not only the object that materialises their acts of care and transformative work. Through land titling, land becomes also an object that materialises their acts towards the state and the corporations, as well as their relations with them. The enactment of land as property constitutes the villagers as natives, that is, as a group of people recognised by the state and as collective proprietors of the lands they inhabit. As those who have taken care of the well and as native proprietors of titled land, the villagers of Vista Alegre claimed that the abandoned oil well was theirs.

While the titling of lands reinforce their understandings and claims of ownership over the oil well, the instruments of environmental regulation for the oil and gas sector serve to reframe their relation to oil debris and to corporate stinginess. Since the early 1990s, mining and oil companies are required to develop and present a PAMA-(Environmental Compliance and Management Plan) a plan to clean up, prevent, and reduce pollution so that corporate production practices comply with environmental standards. The requirements of such plans are a direct response to the extracting industries' pervading environmental degrading extraction practices and poor environmental management in the country. However, since most of the extractive corporations have been unable to comply with their plans, the Ministry of Mining and Energy approved a new norm in 2003 (Supreme Decree 028-2003) authorising the corporations to present PACs (Complementary Environmental Plans) with modifications and deadline extensions. OXY presented its PAMA in 1994, which had to be completed in 2004. When OXY transferred its concession rights to Pluspetrol in 2000, it also transferred to Pluspetrol its PAMA obligations. However, Pluspetrol never complied with the PAMA and presented a PAC in 2004 ( $\mathrm{Lu} 2009$ : 50-52).

As mentioned in the introduction, official documentation confirmed that there were severely environmentally damaged sites that were not taken into account by OXY's or Pluspetrol's PAMAs nor by Pluspetrol's PAC, and that the remediation measures taken were either inadequate or poorly done. From the villagers' point of view, not acknowledging the existence of these sites and not implementing adequate remediation actions not only confirmed the corporations' stinginess but also showed the corporations' will to destroy the sites and then evade responsibility for 
the damage done. For the people of the Upper Tigre River, not allowing Pluspetrol to seal the well 'to kill it' and also asserting ownership of the abandoned well were ways of gaining control over past damages and the possible future wealth the well might generate. They related such damages not only to the compensation amounts but also to what they perceived as the corporations' denial and disregard of the truncated social and biological reproduction of their people in the past. As Stoler (2013) and Gordillo (2014) suggest, ruination entails the destruction of previous places and the colonial disregard of the colonised lives. Thus, affirming ruination and taking control of abandoned oil installations, both the ruins and the remaining toxic waste, are acts of contestation and of negation. By not allowing Pluspetrol to seal the well, the villagers' actions were, I suggest, a negation of the corporations' exclusionary practices. They were also a rejection of the negation of their lives.

The acts of contestation of corporate and state negation implied in taking control over oil debris are, as the next section discusses, not just acts of affirming environmental ruination but also of affirming control, to use Gordillos' words (2014: 58). This presupposes the redefinition of ownership and, with it, of the relations with non-indigenous actors and between the villagers themselves.

\section{Toxic Waste, Pipelines, and the Redefinition OF OWNERShip}

Oil extraction in the Upper Tigre River has destroyed places by saturating them with oil debris. This was also the case in the area where OXY's refinery was located, near the village of Marsella. On this site, in stark contrast to the forests and swiddens that surround Marsella, bare mounds with low guava trees could be seen. Although Pluspetrol's representatives claimed that the corporation had already cleaned up the site, the clean-up was so badly done that OEFA included the refinery at Marsella as one of the 92 contaminated sites that Pluspetrol had to remediate before it left the oil field in 2015. According to Carlos, a villager of Marsella, Pluspetrol was never interested in remediating this area; rather, the company preferred to hide all the remains of past production activities. To do so, Pluspetrol employed local men to gather the crude oil rests that had accumulated in an adjacent stream. With no proper protective clothes, the villagers collected oil rests in plastic bags. A huge, deep hole was dug and the bags 
were thrown into it, together with the detritus of buildings and even the rest of an oil boat. They covered the hole with soil transported by trucks, but oil kept coming up whenever the temperature rose. The barrenness of the terrain where the refinery once stood, and the scattered oil residues that insistently leaked revealing debris hidden in the underground, contrasted with the very visible grid of corroded tubes and pipelines which ran through forests several kilometres and, in some places, crossed under the waters of the Upper Tigre River. These pipelines linked the refinery to the oil wells located further north at Shiwiyaku and further south at San Juan de Bartra.

While people resented Pluspetrol's poor remediation and the conditions under which they had worked, they, nonetheless, claimed ownership of the leaking toxic waste. To the villagers, the appropriation of toxic waste meant that they, as the affected population, had the right to be temporarily employed to clean up the lands that they had once owned. Through paid work, they could renew the ruined streams and soils and, in spite of being dangerously exposed, get access to the wealth that oil was supposed to create. The appropriation of the leftovers of previous oil extraction was, I suggest, a way for them to partially reverse the process of ruination materialised in the hidden debris and the bare landscape. It was an act of affirmation of control.

Such acts of affirmation entail the redefinition, and thereby the multiplication of forms of ownership, and, with them, the co-constitution of the villagers and of the objects they own, as illustrated by the claims of ownership over abandoned pipelines. The villagers of Marsella considered that the corroded pipelines had been OXY's property, since OXY had installed and used them. ${ }^{10}$ From the time OXY dismantled the refinery in the late 1980s, ${ }^{11}$ however, as the villagers noted, neither OXY nor the state had taken care of the tubes, as their corrosion and decay showed. Years later, mestizo traders from Iquitos started cutting the tubes in order to sell them in other Amazonian cities. The people of Marsella, considering these acts as a form of unfair appropriation, decided to hinder the traders. The villagers claimed that the tubes were theirs since they crossed the lands from which families from Marsella had been displaced when oil extraction started and affected the forests and streams the villagers still used. People argued in conversations and communal meetings that the pipelines could not be separated from what most families in Marsella had suffered. Initially, some men from Marsella started cutting the tubes and selling them to traders. Since these sales benefitted only their own families, the villagers 
decided, in a general assembly, that the native community was to act as the collective owner of the corroding pipelines. Later, they made an agreement with a mestizo trader who had his own crew to cut and take out the tubes, for which the village as a collective received an amount of money that was divided and given to all couples with children. In this way, they had some money to buy school supplies and medicines if needed. Additionally, the trader provided them with goods at lower prices than those offered by other traders.

By affirming control of the transformation of abandoned pipes into pieces of tubes to be sold, the villagers wanted, as with the toxic waste, to invert the loss they had suffered by making the pipelines productive for them. The transformation of the ruined pipelines into productive objects presupposed, however, the redefinition of the pipelines as collective property and the villagers as collective owners. By becoming collective proprietors of the abandoned pipelines, they sought to contest and transform several asymmetrical relations. The villagers decided to inhibit further internal differentiation and accumulation that oil activities have produced, and they sought to change the terms of the exchange with non-indigenous merchants. Contrary to what is usually the case in the oil field AB/192, they were able to negotiate better prices for the tubes they were selling, securing at the same time access to other desired goods, without becoming enmeshed in debts, which were difficult to repay, as is still the case with other traders. By transforming themselves into collective proprietors - and ruined pipelines into objects they owned since they were related to their suffering and were part of the lands they once ownedthey sought to transform both ongoing ruination and long-standing colonial asymmetries.

\section{CONCLUSION}

This chapter focused on the toxic waste and abandoned installations of oil field $1 \mathrm{AB} / 192$ and the ways in which the villagers of the Upper Tigre River relate to the oil debris scattered on their lands. The chapter discussed the environmental degradation that oil extraction has left in terms of ruination, waste, and rubble and explored the contesting actions of villagers by showing how these actions relate to divergent notions and enactments of ownership, which are widespread in Native Amazonian contexts.

My aim has been, on the one hand, to look critically at the destructive effects of capitalist proliferation, and to question a strong tendency to redefine capitalist destruction, as Gordillo points out, as something innovative, 
even desirable: 'the unavoidable [and thereby acceptable] side effect of an ever-thriving system' (Gordillo 2014: 80). On the other hand, I have explored and highlighted the Kichwa people's persistent and insistent affirmation of the existence of other ways of life and other understandings. In the case discussed here, the focus has been on the insistence of other understandings and enactments of ownership and thereby of the relation between subject and object. The insistence of these other ways is part of both the inclusion of the Kichwa people of the Upper Tigre River in capitalist and colonialist ruination processes produced by oil production in this area and their counteractions against such processes. Further, this insistence hinges, I suggest, on what Viveiros de Castro (2010: 40) calls a 'political multiplicity'. Such multiplicity entails a shared understanding that nothing is only; entities are both and. The inhabitants of the Upper Tigre River consider themselves as both the descendants of the marriages of Kichwa, Achuar and mestizos, and as native proprietors. Owned land is both the result of acts of care and transformation and a legal titled object, which materialises their relation with the state. The same applies to their claims on toxic waste and abandoned installations. The insistence on the existence, resilience but also the inclusion of other ways (of being and of ownership) hinges on the insistence on multiplicity, of being not only but rather both and. Insisting on multiplicity questions the colonial denial of other epistemes, of other ways of being, and, thereby, the supremacy of the notion of a One World as defined by neocolonial state formations and reinforced by capitalist proliferation (Rivera Cusicanqui 2010; Escobar 2015).

\section{Notes}

1. According to Orta-Martínez (2010), 400 oil-producing wells have been drilled and of these over 200 have been abandoned.

2. During 2013 and 2014, the National Environmental Health Agency (DIGESA), the National Water Authority (ANA), the Agency for Environmental Assessment and Control (OEFA), and the Regulatory Body for Energy Investment and Mining (OSINERGMIN) conducted environmental monitoring in oil field $\mathrm{lAB} / 192$ and oil field 8 . As part of these activities, they registered the existence of contaminated sites and abandoned oil installations whose existence Pluspetrol negated.

3. The organisations were the Federation of Native Communities of the Corrientes River (FECONACO), the Quechua Federation of the Pastaza River (FEDIQUEP), the Federation of Native Communities of the Tigre 
River (FECONAT), and the Kukama Association of the Marañón River (ACODECOSPAT).

4. Depending on the context, the Kichwa of the Upper Tigre River identify themselves as Kichwa or, simply, as villagers. In this chapter, I use both. The Kichwa of the Upper Tigre River speak a Kichwa dialect different from the Quechua spoken along the Pastaza River and the Kichwa spoken along the Napo River.

5. This chapter is based on six months of fieldwork carried out in 2015 and 2016 in four communities of the Upper Tigre River. It also draws on many visits and participation in activities related to local environmental monitoring while I was working in the area from 2007 to 2013.

6. Viveiros de Castro suggests that in Amazonian cosmologies what an entity is depends on the entities' point of view; for instance, what jaguars see as beer, humans see as blood. The differences in their perspective result from their bodies. de la Cadena explores Viveiros de Castro's suggestion that a thing is 'both and' to discuss different understandings and enactments of land and territory.

7. To kill the well means to render it unproductive, to take from it its vitality, its capacity to grow, or make other things/persons grow.

8. An aguajal is a wetland area where aguaje palms (Mauritiea flexuosa) grow.

9. The reformist military government of General Velasco passed the Native Community Law 20653 in 1974 . Four years later, in 1978, the conservative military government of Morales Bermudez replaced it with the Native Community Law 21175 to facilitate large land and forest concessions to private actors.

10. A letter the state-owned PeruPetro sent to me as a response to my questions regarding the Marsella refinery states that oil infrastructure is theirs.

11. The then president of Peru, Alan García, demanded that OXY close down the refinery of Marsella. The reason of his demand is unclear. Representatives of the state-owned PeruPetro explained that it was part of García's nationalising project. Local authorities and the villagers assert that it was a measure to end gasoline smuggling.

\section{REFERENCES}

Arellano Yanguas, Javier. 2011. ¿Minería sin fronteras? Conflicto y desarrollo en regiones mineras del Perú. Lima: Pontifica Universidad Católica del Perú.

Bebbington, Anthony, and Jeffrey Bury, eds. 2013. Subterranean Struggles, New Dynamics of Mining, Oil and Gas in Latin America. Austin: University of Texas. Berjón, Manuel, and Miguel Angel Cadenas. 2018. Motocarro Matador: Variaciones sobre el Dominio. Valladolid: Estudio Teológico Agustiniano.

Blomley, N. 2005. Remember Property? Progress in Human Geography 29 (2): $125-127$. 
2013. Performing Property: Making the World. The Canadian Journal of and Jurisprudence 26 (1): 23-48.

Bohme, Susana R. 2014. Toxic Injustice. Oakland: University of California Press.

Brightman, Marc. 2010. Creativity and Control: Property in Guianese Amazonia. Journal de la Société des Américanistes 96 (1): 135-167.

Brightman, Marc, Carlos Fausto, and Vanessa Grotti. 2016. Introduction: Altering Ownership in Amazonia. In Ownership and Nurture, ed. M. Brightman, C. Fausto, and V. Grotti. New York: Berghahn.

Campanario, Yaizha, and Cathal Doyle. 2017. El daño no se olvida: Impactos socioambientales en los pueblos indigenas de la Amazonía Norperuana afectados por las operaciones de la empresa Pluspetrol. Lima: Equidad.

Cepek, Michael L. 2016. There Might Be Blood: Oil, Humility, and the Cosmopolitics of a Cofán Petro-Being. American Ethnologist 43 (4): 623-635.

Coelho do Souza, Marcela. 2016. The Forgotten Pattern and the Stolen Design: Contract, Exchange and Creativity Among the Kisêdjê. In Ownership and Nurture, ed. M. Brightman, C. Fausto, and V. Grotti. New York: Berghahn.

de la Cadena, Marisol. 2015. Earth Beings: Ecologies of Practices across Andean Worlds. Durham/London: Duke University Press.

Descola, Philippe. 1994. In the Society of Nature. Cambridge: Cambridge University Press.

Escobar, Arturo. 2015. Sentipensar con la Tierra: Las Luchas Territoriales y la Dimensión Ontológica de las Epistemologias del Sur. http://www.aibr.org/ antropologia/ netesp/numeros/1101/110102.pdf. Accessed 21 Dec 2017.

Fausto, Carlos. 2012. Too Many Owners: Mastery and Ownership in Amazonia. In Animism in Rainforest and Tundra: Personhood, Animals, Plants and Things in Contemporary Amazonia and Siberia, ed. M. Brightman, V. Grotti, and O. Ulturgasheva. London: Berghahn.

Gordillo, Gastón R. 2014. Rubble: The Afterlife of Destruction. Durham/London: Duke University Press.

Guzmán-Gallegos, María A. 1997. Para que la Yuca beba nuestra sangre. Quito: Abya Yala.

. 2009. Identity Cards, Abducted Footprints, and the Book of San Gonzalo: Power of Textual Objects in Runa Worldview. In The Occult Life of Things: Native Amazonians Theories of Materiality, ed. F. Santos-Granero. Tucson: University of Arizona Press.

- 2015. Amazonian Kichwa Leadership: The Circulation of Wealth and the Ambiguities of Mediation. In Images of Public Wealth or the Anatomy of WellBeing in Indigenous Amazonia, ed. F. Santos-Granero. Tucson: University of Arizona Press.

- 2017a. Between Oil Contamination and Consultation: Constrained Spaces of Influence in Northern Peruvian Amazonia. Third World Quarterly 28 (5): 1110-1128. 
2017b. Nukanchi Nawpa Timputa Yarisha Tantarishun. Surcando nuestra memoria. Iquitos: FORMABIAP.

Kuletz, Valerie. 1998. Tainted Desert: Environmental and Social Ruin in the American West. New York: Routledge.

La Torre, Lilly. 1998. Sólo queremos vivir en paz. Copenhagen: IWGIA.

Lu, Mercedes. 2009. The Rio Corrientes Case: Indigenous People's Mobilization in Response to Oil Development in the Peruvian Amazon. Master's thesis, University of Oregon.

ONERN. 1984. Inventario y evaluación de recursos naturales de la microrregión Pastaza-Tigre. Lima: Departamento de Loreto.

Orta-Martínez, Marti. 2010. Oil Frontiers in the Peruvian Amazon, Impacts of Oil Extraction for the Achier of Rio Corrientes. PhD dissertation, Universitat Autònoma de Barcelona \& Institut de Cuenca i Tecnologia Ambientals-UAB, Barcelona.

Rivera Cusicanqui, Silvia. 1990. Liberal Democracy and ayllu Democracy in Bolivia: The Case of Northern Potosí. The Journal of Development Studies 26 (4): 97-121.

- 2010. The Notion of 'Rights' and the Paradoxes of Postcolonial Modernity: Indigenous Peoples and Women in Bolivia. Critical Humanities and Social Sciences 18 (2): 29-54.

Santos-Granero, Fernando. 2009a. Introduction: Amerindian Constructional Views of the World. In The Occult Life of Things: Native Amazonians Theories of Materiality, ed. F. Santos-Granero. Tucson: University of Arizona Press.

- 2009b. Vital Enemies: Slavery, Predation and the Amerindian Political Economy of Life. Austin: University of Texas Press.

Stoler, Ann Laura. 2008. Imperial Debris: Reflections on Ruins and Ruination. Cultural Anthropology 23 (2): 191-219.

- 2013. The Rot Remains: From Ruins to Ruination. In Imperial Debris, ed. A.L. Stoler. Durham/London: Duke University Press.

Viegas, de Matos Susana. 2016. Temporalities of Ownership: Land Possession and Its Transformations among the Tupinambá. In Ownership and Nurture, ed. M. Brightman, C. Fausto, and V. Grotti. New York: Berghahn.

Vigh, Henrik, and David Sausdal. 2014. From Essence Back to Existence: Anthropology beyond the Ontological Turn. Anthropological Theory 14 (1): 49-73.

Viveiros de Castro, Eduardo. 2004. Exchanging Perspectives: The Transformation of Objects into Subjects in Amerindian Ontologies. Common Knowledge 10 (3): $463-484$.

- 2010. The Untimely, Again. In Archeology of Violence, ed. P. Clastres. Los Angeles: Semiotext(e). 
Walker, Harry. 2012. Under a Watchful Eye: Self, Power and Intimacy in Amazonia. Berkeley: University of California Press.

Yusta-García, Raúl, M. Orta-Martínez, P. Mayor, C. González-Crespo, and A. Rosell-Melé. 2016. Water Contamination from Oil Extraction Activities in Northern Peruvian Amazonian Rivers. Environmental Pollution 225: 370-380.

Open Access This chapter is licensed under the terms of the Creative Commons Attribution 4.0 International License (http://creativecommons.org/licenses/ by $/ 4.0 /)$, which permits use, sharing, adaptation, distribution and reproduction in any medium or format, as long as you give appropriate credit to the original author(s) and the source, provide a link to the Creative Commons license and indicate if changes were made.

The images or other third party material in this chapter are included in the chapter's Creative Commons license, unless indicated otherwise in a credit line to the material. If material is not included in the chapter's Creative Commons license and your intended use is not permitted by statutory regulation or exceeds the permitted use, you will need to obtain permission directly from the copyright holder.

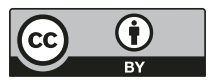




\title{
Extractive Pluralities: The Intersection of Oil Wealth and Informal Gold Mining in Venezuelan Amazonia
}

\author{
Amy Penfield
}

\section{INTRODUCTION}

The image is becoming increasingly familiar: rows of muscled warriors clad with bright feather headdresses and heavy bead collars march forward. Spears are grasped by some, megaphones by others, with those at the centre clutching banners loudly denouncing mining in bright red letters. These are perhaps the more striking-and certainly most wellknown-images of indigenous responses to mining in South America. There are certainly subtler portrayals depicting steadfast but wise spokespersons fighting for the dignity of their people amidst oil prospecting and large-scale gold mining projects on indigenous territory, among them Davi Kopenawa Yanomami of the lowlands and Máxima Acuña de Chaupe of the Andes. Both these forms of representation portray resource extraction as the epitome of environmental degradation, unethical treatment of local communities, and neoliberal power differentials that generate poverty on a global scale (see e.g. Kirsch 2014; Li 2015;

\footnotetext{
A. Penfield $(\bowtie)$

University of Copenhagen, Copenhagen, Denmark
}

(C) The Author(s) 2019

C. Vindal Ødegaard, J. J. Rivera Andía (eds.), Indigenous Life

Projects and Extractivism, Approaches to Social Inequality and

Difference, https://doi.org/10.1007/978-3-319-93435-8_3 
Sawyer 2004; Shever 2012). If local populations seem not to be outwardly rejecting mining, then at the very least they are expected to promote sustainability as a part of their intrinsically environmentalist ethos.

Resounding tropes of resistance, while pertinent accounts of indigenous reaction to extraction in many settings, may in other cases eclipse more understated and multifaceted responses that digress from, and perhaps even clash with, these popular representations. In other words, 'green-washed' depictions of indigenous resistance to extraction and their inherent conservationist ideology risk oversimplifying indigenous relationships with states, industries, and the environment. This is not to suggest that indigenous peoples welcome extraction with open arms, but that their response is more layered than it might at first appear, and perhaps interwoven with their social and cosmological ethos (see also Ødegaard, this volume). John-Andrew McNeish (2012) points out that outright rejection of resource extraction among indigenous peoples in South America is in fact quite rare. He shows that their narratives on environmental protection are just one in a constellation of interests that emerge in the face of these encroaching activities, with matters of autonomy, community well-being, and compromise often taking a far more prominent place within broader concerns (see also Anthias 2016). How, then, might we evaluate the transformation of indigenous life projects in the contexts of resource extraction when seemingly counterintuitive realisations are unveiled?

My doctoral fieldwork drew attention to disjunctures such as these. During 24 months living with a hunting and horticulturalist indigenous Yanomami subgroup called the Sanema, I noticed that extractivism was central to their burgeoning relationship with the state and to transforming ideas of personhood in unanticipated ways. Their engagement with extraction was not one of antagonism and resistance, but, on the contrary, of gradual-albeit fraught-absorption into the much desired wealth of the petroleum-financed economy and the global gold market. Their unique location in the resource-rich forests of the Venezuelan petro-state has meant that extraction has a twofold bearing on their lives: first as an indirect phenomenon in the form of oil wealth dispensed to Venezuelan citizens and second as the intimate reality of gold mining in their territory. In this sense, extraction is a plural experience in Sanema lived worlds, with multiple and significant impacts on their daily lives. On the one side, the wider economic experiences of engaging more directly as citizens of a petro-state offers opportunities never before experienced. Oil extraction, although a 
process far removed from everyday Sanema life, indirectly influences their contemporary encounters with national society and political engagement. On the other side, intimate encounters with and participation in small-scale gold mining results in more direct but ambivalent evaluations of resources, specifically concerning nonhuman animacy and related notions of morality, as well as the promise of fortune. Thus, both forms of extraction interlace in subtle ways to create a mix of both hope and anxiety among my Sanema interlocutors.

The ethnography outlined in this chapter shows that Sanema life projects are intimately bound up with the pluralities of extractivism, and, furthermore, divergent to the more common tropes of opposition to large-scale mining companies. Crucially, however, this dual engagement plays out as a gradual and complex integration into national and global economies.

\section{Resource as a Political Encounter}

The essential substance that places Venezuela squarely on the resource map-oil-is central to Sanema contemporary life. This is not because the Sanema inhabit lands rich in petroleum as in Ecuadorian Amazonia (see Cepek 2012), but because oil seeps into political possibilities and civil imaginaries in ways that cannot be overestimated, even for ostensibly isolated indigenous communities. This has been the case since the discovery of oil in Venezuela in 1908, ${ }^{1}$ but all the more so since the commencement of the socialist 'Bolivarian Revolution' ('Bolivarianism'), ${ }^{2}$ forged by the late Hugo Chavez. President Chavez proudly declared this a movement of 'twenty-first century socialism,' a regime of social welfare reforms and poverty-reduction measures - from free education and healthcare to subsidised food-implemented to provide for the entire Venezuelan population. Most significantly, this political strategy was financially bolstered by the immense hydrocarbon reserves of the country, and indeed its specific purpose was to redistribute oil wealth to citizens whose access had previously been restricted: poor barrio dwellers, women, and indigenous peoples among them. As such, during the early years of Bolivarianism, greater interest in the nation's indigenous peoples emerged side by side with the significant and interrelated factors of a spike in oil prices, a rise in popular politics, and the flood of petro-dollars into Venezuelan public life.

During my fieldwork between 2009 and 2011 in southern Venezuela, Chavez's polarising renown, paralleled by the inflated price of oil, was at 
its zenith. His policies and charismatic personality were at the centre of widespread and impassioned debates among the general population, and I witnessed them daily from non-indigenous (criollo) acquaintances, taxi drivers, shopkeepers, bureaucrats, and even my Sanema interlocutors. For those opposing his rule, he was nothing more than a populist autocrat who divided the population and swindled the nation's wealth, which alongside strict economic regulations caused what would ultimately be economic collapse. Many, however, supported his programme to empower previously disenfranchised peoples through participatory democracy and equal economic opportunities. Indigenous peoples stood, for the first time, in the spotlight of this era of inclusion. Theoretically at least, spaces for recognition were carved out in political settings: in the national assembly, in a new Ministry of Popular Power for Indigenous Peoples, in promises of legislative reform, and in the newly drafted constitution of 1999. The constitutional amendments, which were implemented directly after the election of Hugo Chavez, included a new section on native peoples, recognising their rights to distinct cultures, languages, schooling, traditional health practices, and territory.

My Sanema hosts benefitted from this new recognition, but not, perhaps, as you might expect. Most Sanema people I spoke to were not aspiring to gain political recognition within this multicultural framework, at least not recognition as indigenous peoples with specific rights. This is in part because, broadly speaking, the Sanema have a weak sense of ethnic identity as they have only very recently had contact with states and the associated political ideologies that prompt notions of bounded ethnic groups (see Brown 1993; Taylor 1997; Whitehead 1999; Wroblewski 2014). To a degree, the Sanema choose to align themselves more closely with their neighbouring Carib-speaking group with whom they share a territory-the Ye'kwana-than they do with other distant Sanema peoples (see Penfield 2017). ${ }^{3}$ In contrast to the Sanema, the Ye'kwana are politically savvy (see Lauer 2006) and have established their own tribal council (KUYUJANI) that protects the rights of indigenous peoples in the region that they inhabit. On paper, this organisation claims also to represent the Sanema by including them in their lobbying activities and regular meetings. Active participation on the part of the Sanema, however, is minimal and, when asked, they seemed rather indifferent; as one stated to me, 'We used to go to meetings with the Ye'kwana, but they never listened to us, so we stopped.' Broader ethnic and interethnic collaborations on the part of the Sanema tend to be premised on dependency, trade, or a desire to 'be like the criollos 
(non-indigenous peoples)' (see Penfield 2016). Political cohesiveness, multicultural activities, or resistance to state activities in their territory was never a topic of conversation during my two years living among them.

Rather than asserting claims for specific cultural rights-a movement they were unacquainted with-something entirely different was going on. During the time of fieldwork, my Sanema hosts were actively engaged in another, perhaps directly contradictory, political agenda. They desired to become subsumed into the Bolivarian Revolution as citizens of a wealthy oil state. That is to say that they were-knowingly or otherwise-drawn into a homogenising 'criollo-isation' of political recognition. I shall utilise Valdivia's term 'petro-citizenship' to describe this engagement, which she characterises as a politico-economic configuration associated with petroleum governance that 'shapes not only people's belonging within the boundaries of the nation, but also political identities through which to claim rights to the benefits associated with national membership' (Valdivia 2008: 457). Hence, the Sanema were gradually developing into petrocitizens (or 'petro-project citizens,' as I describe below) who benefited from the same oil-funded provisions and rights as all Venezuelans. While the newly drafted 1999 constitution testified to upholding rights to traditional cultures, equal and democratic rights were arguably promoted with greater fervour. The provincial office of the Ministry of Popular Power for Indigenous Peoples nearest my field site, for instance, was more often than not promoting elections, standardised development projects, grants to attend high school in the cities, and football tournaments, rather than multicultural initiatives related to indigenous religions, languages, healthcare, or education. This is where we see how petroleum-funded resources become a political encounter. Although the process of extraction is far removed from daily Sanema life, the nation's oil is experienced as the pervasive and financially prosperous socialist projects of Bolivarianism.

\section{Petro-Project Citizenship}

The dispensation of oil wealth also comes in the form of cheap gasoline, the highly subsidised and ubiquitous oil derivative that, as will be discussed in the next section, is used to facilitate other forms of extraction (see Penfield forthcoming). ${ }^{4}$ Indigenous peoples are allocated a monthly quantity of gasoline, typically several large 200-litre drums, that only they are entitled to transport within indigenous territory if accompanied by the mandatory paperwork. Various military checkpoints currently line Amazonian rivers in 
an effort to mitigate fuel smuggling in the region; they flag down each passing boat and check the gasoline licence, which is normally only administered to indigenous residents. The fuel is proffered as a means to feed their growing dependence on gasoline-run machinery, but their rights over large quantities also give them considerable power over this highly valued substance in Amazonia. However, it is the grassroots development projects, the 'petro-projects' if you will, known as 'communal councils' (see Ellner 2009; Valencia 2015; Wilde 2016), that are the medium through which indigenous peoples experience most directly the wealth of the petro-state. These 'communal councils' (consejos comunales) are development initiatives funded by state petro-dollars deposited directly into community bank accounts, later used for projects that are implemented by the communities themselves. Since the passing of the Law of the Communal Councils (Ley de los Consejos Comunales) in $2006,{ }^{5}$ a large proportion of indigenous communities have set up, or are in the process of setting up, communal councils in their forest settlements. By the time of my fieldwork in 2009, many had already reaped the benefits of infrastructural development through their communal councils-water purification systems; tools for farming cooperatives; boats; outboard motors; school buildings; and clinics-while others were beginning the long application process and the esoteric bureaucratic procedures required to set one up (see Penfield 2016).

When I arrived in my Sanema host community to commence fieldwork in 2009, it struck me as unlike any other settlement I had visited prior to that point. After walking up the short path from the river port, what came into view was an unusual hodgepodge of structures. There were the anticipated flimsy pole and thatch household dwellings, but sprinkled between them were a number of odd-looking buildings made from breeze block, metal, corrugated iron, and solar panel-clad roofs. At the far side of the community, peeking above all other structures like a clumsy giant, rose a steel tower with a large metal tank triumphantly perched on top. What was also striking about these awkward-looking buildings was the fact that they were all noticeably incomplete. I later learned the intended purpose of these irregular structures: one was a breeze block school building with already crumbling half-erected walls; another a canteen that had proceeded no further than a large corrugated iron roof; and finally a water purification tower that stood rusting and abandoned, having never delivered one drop of water in its many years since being built. I was soon to discover that all these constructions were the result of projects funded by the settlement's communal council that had been set up in 
the years prior to my arrival. The community explained that the president of the communal council had not done a good job of managing their money. Other communities, in contrast, were perceived to administer their communal councils more effectively; one resident told me these other settlements had 'received the same amount of money but their schools are much better with proper walls and a door and a cement floor.' During that time, members of my host community were in the process of discussing how they could appoint a new president for the communal council and subsequently apply for the release of additional funds, remaining hopeful that the buildings would one day be completed.

It gradually became clear to me that the Sanema's burgeoning relationship with the socialist regime was realised most strikingly through continual struggles to manage their oil-funded communal councils. Infuriated discussions frequently revolved around their failure to navigate bureaucratic procedures, hiring non-indigenous labourers for construction projects they had no skills to undertake themselves, and budgeting so that the enormous funds allocated could be monitored and spent responsibly. In spite of these shortfalls, their newfound acquaintance with the workings of communal councils was infused with hope and ultimately became emblematic of their politicisation as active petro-citizens. Even since Chavez's death, many Sanema continued to be very much immersed in a setting in which citizenship is mobilised by the dispensation of oil wealth. After the election of the new Venezuelan President Nicolás Maduro in April 2013, I called one of my Sanema friends to find out his views on the recent dramatic changes. $\mathrm{He}$ exclaimed without hesitation that 'we, the Sanema, are with Maduro because he gives us lots of credit,' a statement that powerfully underscores the continuity of this political engagement through the distribution of wealth funded by oil. Yet, encounters with extraction do not take place solely at the level of national political and economic ventures. The Sanema also engage with resources on a far more intimate level.

\section{Extraction as an Intimate ReALity}

Engaging in participatory democracy as petro-citizens is only one component of the Sanema's dual encounter with extraction. Since at least 2005, the Sanema have also had an immediate encounter with extraction in the form of gold mining in their territory, activities that have provoked a blend of anticipation, anxiety, and puzzlement. In part due to the informal nature of this activity, Sanema experiences with mining are not consistent with the 
common trope of opposition to powerful 'leviathans' (Golub 2014). Despite being a form of artisanal mining, the large number of indigenous and non-indigenous individual prospectors entering these faraway regions of Amazonia in search of gold creates a form of large-scale open-cast extraction with considerable impact on the environment. An extensive area had reportedly been deforested and a rudimentary camp grows bigger by the day. Referred to locally as minería ilegal, these informal mines are largely obscured due to the remote location of the site, where small crews work with large hydraulic water cannons that blast large craters into the earth. ${ }^{6}$ The resulting sludge that fills these openings is poured over a carpet-lined sluice box, and the heavy sediment that settles is then mixed with mercury to create a gold amalgam. This clandestine but legendary mine was visited with greater frequency by my Sanema hosts because, much like the Bolivarian Revolution, it offered opportunities never before known. The Sanema do not earn money by working in the mine site itself, due, they repeatedly told me, to a general aversion to the mine site and its workers, along with an acute fear of removing gold from the earth, as discussed below. Instead, they make the laborious journey to the hinterland location and offer supplies such as food and gasoline to the labourers and owners of the mining machinery in exchange for gold. I was regularly told that the Sanema could potentially make tremendous riches that would enable them to, as one man stated, 'all return home rich!' Despite these pragmatic motivations, mining activities were also accompanied by a profusion of judgements and concerns relating to gold's cosmological origins.

Although the phenomenon of resource extraction in indigenous territory is often explored in relation to themes of land and land rights, we might question what people mean when they speak of land. It is particularly interesting to note that in scholarly literature the concept of land in Amazonia is often analysed as territorial space or a topographical system, particularly in relation to conceptualisations of powerful others or nonhuman beings who inhabit nearby forest spaces (see e.g. Alexiades 2009; Ewart 2013; Reig 2013). Literature from the Andes, on the other hand, places the earth at the centre of the analysis, the land itself (see Canessa 2012; de la Cadena 2015; Harris 2000). This divergence in ethnographic accounts of what land encapsulates might emerge in part from a focus within Amazonian scholarship on the plethora of beings that inhabit the rich forest landscape-peccaries, monkeys, jaguars, and giant ceiba trees-which in some ways overshadow any insights into the land itself (see Rival 2002). The Andean landscape, on the other hand, which is far sparser in animal and plant life, becomes a habitat where animate beings permeate the earth 
rather than roam and grow above it. In other words, nonhuman life in the lowlands has long been explored as animals and trees and in the highlands as infused within the mountains, the lakes, and the land (see de la Cadena 2010; Sallnow 1989; Sax 2015).

In cases of mining in the Andes, telluric animacy has been associated with a necessary negotiation with supernatural forces, in which miners provide offerings to the spiritual guardians of the earth (Supay) in order to bring good fortune and mitigate danger (Nash 1993). In addition to requiring recompense for resources extracted, these occult forces might attack out of sheer malevolence (see Sallnow 1989). While frequently portrayed as hostile, Andean land also has a tenacious quality as a resolute environmental activist. Marisol de la Cadena (2010), for instance, suggests that we consider the mountain Ausangate in Peru as a powerful political activist in its own right, a wilful intentional agent who opposes mining concessions in its foothills so severely that it threatens to kill those occupying its lands. She does not present the mountain as benevolent per se, but rather as a political liberator and guardian of indigenous worldviews. Even in this case, the land is valorised as a prudent protector of the pristine, the virtuous, and the sustainable.

While indigenous Amazonians are equally thought to be guardians of the environment who fight to safeguard their territory, depictions of the actual earth within this broader discourse of environmentalism, and notions of what might be extracted from the earth, are few and far between. One notable exception is Michael Cepek (2016; see also Krøijer, this volume) who has described how Cofán conceptualise the extraction of oil on their territory as intimately bound up with its placement beneath the earth, because subterranean entities 'have a form of animacy that is normally the unique property of humans' (Cepek 2016: 27-28). Indeed, it is precisely this underground location that thrusts oil into the realm of unpredictability. Nevertheless, this is not an exclusively indigenous perspective, as non-indigenous garimpeiros also regard gold's telluric origins as the primary source of its force, taking form in miners stories as an alluring woman or blood-seeking animal, both representations that parallel a supposed 'absence of clear-cut morals' (Slater 1994).

Jacques Lizot has noted that the Yanomami consider the ground a place of multiple layers, infused with 'rottenness, inhabited by grotesque, giant worms' (Lizot 2007: 271-76; quoted in Kelly 2011: 235, n. 4). Like the Yanomami, my Sanema hosts see the underworld as a dreadful and ominous place, where expelled illness is thrown during shamanic incantations, 
an action that was strikingly portrayed during my host father's healing sessions in which he gestured a scooping and throwing movement from sick patients while chanting, 'lute, lute, masitali, masitali!' ('it smells bad, it smells bad, in the earth, in the earth!'). Many of my interlocutors described the terrestrial domain as the home of malicious dwarf cannibalbeings known as 'the hungry ones' (obinamo töpö) who emerge from their vile subterranean worlds and voraciously consume the Sanema if puberty rites are not strictly adhered to. Even a baby landing directly on the earth when born is a bad omen, an event that is said to cause lifelong sickness (see also Gow 1989 for other fearful conceptualisations of the earth).

In a footnote to The Falling Sky, Bruce Albert notes that, among the Yanomami, Christian burials in the earth are considered a 'revolting practice' that prevents the parting of the ghost and in turn the cessation of mourning (Kopenawa and Albert 2013: 525, n. 44). Conklin makes a similar observation among the Wari,' who regard burial as horrific because the ground is 'cold, wet and polluting' (Conklin 2001: xviii). One of my Sanema hosts indeed once told me that one must never bury the people they love, but instead 'must do what the ancestors did and burn them.' Apart from this fear of being forever entombed in the cold earth, another woman also stated that vengeful spirits of the dead (nopolipö töpö) live underground, and that the hideous 'man of light' (molökolia) pulls them from the earth and takes them up to the sky on his shoulders. Narrated in the genre of a myth, this terrifying story was reportedly used to prevent young boys from playing in the bright moonlight at night. The gesture of pulling souls from the abominable earth was, one research participant told me with visible unease, an action most appalling to envisage. The subsoil and the occult forces that it harbours in both the Andes (see Stensrud, this volume) and in Amazonia, then, are a source of much anxiety.

It is not surprising, then, that the Sanema's engagement with mining is ambivalent, both because the activity itself invades this menacing telluric realm, but also because the gold residing therein is greedily removed. Gold was described as silimo, or speedy (Spanish apurado); promoting a rapid movement because of its small weightless form, but also due to people's eagerness to bring it back to the commercial centres in order to obtain their long awaited riches. Many rumours circulated about 'the curse of gold,' a relatively widespread phenomenon where informal mineral extraction is concerned (see Biersack 1999; High 2013; Shipton 1989), related to the speedy squandering of gold money so that prospectors are forced to immediately return to the mine to yet again toil away for their treasures. But the 
speediness of gold for the Sanema has an altogether more menacing undertone, and in fact the quick squandering of their wealth was the least of their worries. Over and over again gold was described as having a malevolent force that stems from its derivation beneath the earth. Yanomami activist Davi Kopenawa describes gold as emerging from fragments of stars that were placed under the earth by the mythical hero Omama because such minerals are 'evil and dangerous things, saturated with coughs and fevers' (Kopenawa and Albert 2013: 282). The present-day earth is described as a layer of the sky that fell in primordial time, marking the inception of the modern era. The event itself was catastrophic, followed by the stabilisation of all beings in the cosmos, but also by the onset of all known illness and suffering that evidently originates in part from these beguiling but deleterious resources.

My Sanema research participants described the threat of gold as emerging from its pernicious 'spirit carers,' the orotil töpö (literally, gold people), tutelary spirits who 'look after' gold and enact revenge upon those who remove it from their land, or those who have it in their possession for any length of time. In fact, more often than not, vengeance is obtained by attacking family members of miners or those in close proximity to the gold rather than solely the miners or smugglers themselves, a form of deflected causality common in Amazonia (see Penfield forthcoming). When a whooping cough epidemic acutely afflicted most of the children in my host community, the women blamed the men who had stayed there too long with gold in their pockets on their way down from the mine. They said the children were ill because the gold was enacting retribution. One man described it to me in a hushed voice: 'When you have gold you must leave the community as quickly as possible. It is only when you take it to a trader in the city that you are truly safe.' Another described a time when his father almost died when he had malicious gold in his possession for too long: 'I won't go to the mine because of my father's mining experience in the past. He worked for some Ye'kwana men and they gave him a little bit of gold in payment and he almost died because he brought it to the house and left it there.' Importantly, however, although gold was clearly a dangerous substance with malicious intentionality, this did not stop many Sanema from continuing to pursue mining activities.

\section{The Dangers of Acquiring 'Good Things'}

One might argue that these occult depictions of gold subtly reflect emerging anxieties over extraction in Sanema territory and the changing dynamics that result from these activities: that is, close and regular contact with 
the criollo realm, and the alienation, greed, and breakdown of social ties that are generally thought to result. Indeed, many anthropological studies of mines and mining have shown that the boundary between surface and underground often has profound significance, marking a borderline between life and death, good and evil, human and divine, indigenous and non-indigenous, and so on (see also High 2013: 681 for a case of breakdown of purity and pollution through mining the earth). Taussig's work (1980) - which interprets Nash's account of Bolivian tin miners who make a pact with the devil (Supay, also known as El Tío)—asserts that such actions are a means to mitigate the morally contaminating effects of the capitalist economy and resource wealth (see also Onneweer 2014). Yet, to portray similar anxieties as the sole concern surrounding gold extraction in the Sanema case would oversimplify their experiences and overlook a profound conceptualisation of their cosmos and the many relational beings who inhabit it (see also Ødegaard 2017). Moreover, many saw resources as an essential component of community well-being because the riches obtained from mining are compassionately shared with kin.

Among my Sanema hosts, contentment (pi mönaja) was often expressed as realised through the receipt, sharing, and bestowal of material things within kin circles, predominantly manufactured goods (matitö), which were explicitly referred to as 'good things' or 'things we want.' The term for 'suffer'-pebalo - also means 'to be without things' or 'to be poor,' implying an emotional sadness closely linked to a deficiency in material possessions. ${ }^{7}$ Whereas in the past such suffering may have predominantly been associated with lack of sustenance, such as the meat that kin provide, now it is becoming progressively bound up with goods. Lizot has noted a similar sentiment among the Yanomami: 'If the Indians strive for profit, it is then not for the pleasure of accumulating wealth, but for the prestige and the private satisfaction involved in the division and redistribution of possessions' (Lizot 1991: 184). Sanema men who make an effort to spend periods of time trading supplies at the mine for gold in order to buy their kin clothes, shoes, pots, machetes, and beads are thought to be admirable, caring people. Conversely, those who do not bestow such gifts (tota jötöpo) are presented as inattentive people, likened to enemy others, sorcerers or immoral criollos. Parents of naked children were regularly described as bad parents, expressed by the disparaging phrase 'he leaves his children naked.' Nevertheless, giving gifts to family members is more than merely a generous act, it also protects them from danger. Failure to obtain 'good things' from kin results in anguish comparable to illness, manifesting in a worrying 
withdrawal into one's hammock, a complete abandonment of the community, or even the loss of one's soul. A child who is 'soft' (Sanema osiati) after birth remains so in their naked unadorned form, and can become 'hot,' 'distressed,' or 'sad' without bodily embellishments given by their kin. Hence, the moral primacy of sharing (köpalo) impels one to privilege generosity (öd $\ddot{o} i \ddot{o})$ over the satisfaction of personal desires (see also Storrie 2006: 230).

Compassion through the bestowal of gifts is also notable in the Sanema term used for Bolivarian projects-pasila palai-which describes the material assistance they receive, but also refers to the alleviation of suffering just mentioned. When asked about President Chavez, many of my interlocutors described him in a joyous tone as their father (Sanema ipa jawani) because he cared for them through the bestowal of goods, as would any compassionate kin (see also Caballero-Arias 2003: 358). It is clear to see how participation in the processes of both Bolivarianism and gold extraction-and the goods that issue forth from both forms of engagementfacilitate kin contentment. Even though there is some indication that gold inhabits a dangerous realm, and perhaps even evokes veiled anxieties about the encroaching market economy, Sanema people nevertheless take part in this treacherous activity due to their responsibility as devoted and compassionate kin. In a sense, participation in mining is a trade-off between the dangerous propensity of the vengeful gold and the broader well-being that resources provide (see also Kelly 2011: 65-66).

\section{Conclusion: Extractive Pluralities}

Contrary to the neo-colonial indigenous icons of what have been referred to as the 'ecologically noble savage' (Redford 1991) or the 'hyper-real Indian' (Ramos 1994), the Sanema case underlines the need to look beneath conventional accounts of resistance to resource extraction on indigenous territory. Firstly, the ethnography presented in this chapter has shown not only that oil-funded projects have initiated new forms of political engagement and citizenship but also that they facilitate sociality at the local level through the management of petro-projects. Secondly, for the Sanema, nature is not conceptualised as a pristine ecosystem that requires protection; at best it is an environment that exists to be exploited and at worst it is the realm of the wicked. Rather than valorising nature and acting as its guardians, then, the Sanema view it-in particular the subsoil-as a terrifying vengeful domain, a prototypical 'other' that is not protected but warily 
manipulated. Participation in small-scale gold mining results in more direct but ambiguous encounters with resources; experiences which, although manifesting as troubled assessments of gold's animacy, do not entirely curtail the desire to participate nor stymie the promise of ensuing fortune.

Both forms of extraction facilitate the realisation of compassion among kin through the wealth acquired. As such, rather than adhering to accounts of occult economies in representing a denunciation of the morally contaminating capitalist economy, other facets of daily life must be taken into consideration. In order to be a convivial and self-sufficient unit, for example, the Sanema must engage with the wider national economyeven though experienced as a 'trade-off'-in order to access the goods that make their kin content, a materialised expression of compassion and generosity (see also Walker 2013). Contrary to the perception that incorporation into the extractive economy brings with it individualism and social degeneration, in the Sanema case it is a sign of the hard work one has undergone to obtain goods for kin (see also Allard 2010: 26; Alès 2000: 135). Wealth, in this case, is human relationships, not individual self-interest.

What is particularly interesting about this case is the fact that the two realms of extraction are exploited in similar ways, but furthermore, that they are simultaneously intertwined because the Venezuelan petro-state inadvertently buttresses gold mining in the lowland states. As mentioned earlier, the fostering of indigenous political participation not only allows, but in fact requires, them to access large quantities of fuel in order to travel to the cities and navigate political structures with ease. The distribution of oil wealth and the associated allocation of subsidised gasoline results in large quantities of the fuel entering the mine site and feeding the hydraulic cannons that power the mine. In other words, without oil, there would be no gold. One could also argue that not only are these two economies (oil and gold) linked, but that between them stand the Sanema, who are taking advantage of oil wealth distribution to reap the benefits of gold revenue. This shows us, then, that the Sanema's encounter with extraction in its many forms plays out as a gradual absorption into the national and global economies in very subtle ways. It is clear that asymmetries are emerging as a result of this process, particularly notable in the frustrations over communal council management, as mentioned briefly above. However, for the time being anyway, grievances over the emergence of inequalities are not excessively foregrounded. Instead, the Sanema's sense of excited anticipation over ceaseless oil and gold abundance remains at the heart of their daily discussions. Existing betwixt two forms of extraction, 
then, is a complex and multifaceted experience, because engagement with resources precludes any simple dualisms of natural and produced, them and us, well-being and deprivation, sustainable and destructive. It is this complex setting that shapes indigenous life projects in unexpected ways, yet ways that are nevertheless determined by distinct realisations of autonomy and well-being.

\section{Notes}

1. Venezuela has the largest oil reserves in the world, estimated in 2016 to be over 300 billion barrels in total (http://www.opec.org/opec_web/en/ data_graphs/330.htm).

2. This socialist movement was named after the nineteenth century liberator Simón Bolívar, who led the struggle for independence throughout South America.

3. The association between the Sanema and the Ye'kwana consists of a long history of antagonism, predominantly stemming from the Ye'kwana's monopoly over access to manufactured items. Beginning with an extended period of violent raids in the 1930s, the relationship later developed into one of co-dependence in which the Sanema built nearby settlements in order to provide labour in exchange for goods.

4. Gasoline is extremely cheap in Venezuela as a result of a subsidy introduced in the 1940s when the country was gaining prominence as a global producer of oil.

5. Officialised originally on 10 April 2006, code number 5806. The law was updated on 28 December 2009 to the Ley Orgánica de los Consejos Comunales with the new official code number 39335 . Although this was the first law of its kind on community development projects, it was built on already existing practices of neighbourhood organising (junta de vecinos).

6. The term mineria artesanal, on the other hand, refers to the delegitimised practice of gold panning. In the media, the larger open-cast placer mines run by individual prospectors have also been referred to as 'wildcat mines.'

7. Compare to the Quechua term waqcha, which refers to poverty in terms of not having relatives or social networks (see Altamirano 1988).

\section{REFERENCES}

Alès, Catherine. 2000. Anger as a Marker of Love: The Ethic of Conviviality Among the Yanomami. In The Anthropology of Love and Anger: The Aesthetics of Conviviality in Native Amazonia, ed. Joanna Overing and Alan Passes. London: Routledge. 
Alexiades, Miguel N., ed. 2009. Mobility and Migration in Indigenous Amazonia: Contemporary Ethnoecological Perspectives. New York: Berghahn Books.

Allard, Olivier. 2010. Morality and Emotion in the Dynamics of an Amerindian Society (Warao, Orinoco Delta, Venezuela). PhD dissertation, University of Cambridge.

Altamirano, Teófilo. 1988. Cultura Andina y Pobreza Urbana: Aymaras en Lima Metropolitana [Andean Culture and Urban Poverty]. Lima: Fondo Ed. PUCP.

Anthias, Penelope. 2016. Indigenous Peoples and the New Extraction: From Territorial Rights to Hydrocarbon Citizenship in the Bolivian Chaco. Latin American Perspectives 11 (08): 1-18.

Biersack, Aletta. 1999. The Mount Kare Python and His Gold: Totemism and Ecology in the Papua New Guinea Highlands. American Anthropologist 101 (1): 68-87.

Brown, Michael F. 1993. Facing the State, Facing the World: Amazonia's Native Leaders and the New Politics of Identity. L'Homme 126-128: 307-326.

Caballero-Arias, Hortensia Raiza. 2003. Engaging in Politics: Yanomami Strategies in the Face of Venezuela's National Frontier Expansion. PhD, University of Arizona.

Canessa, Andrew. 2012. Intimate Indigeneities. Durham: Duke University Press.

Cepek, Michael. 2012. The Loss of Oil: Constituting Disaster in Amazonian Ecuador. Journal of Latin American and Caribbean Anthropology 17 (3): $393-412$.

- 2016. There Might Be Blood: Oil, Humility, and the Cosmopolitics of a Cofán Petro-Being. American Ethnologist 43 (4): 623-635.

Conklin, Beth A. 2001. Consuming Grief: Compassionate Cannibalism in an Amazonian Society. Austin: University of Texas Press.

de la Cadena, Marisol. 2010. Indigenous Cosmopolitics in the Andes: Conceptual Reflections Beyond "Politics". Cultural Anthropology 25 (2): 334-370.

- 2015. Earth Beings: Ecologies of Practice across Andean Worlds. Durham: Duke University Press.

Ellner, Steve. 2009. A New Model with Rough Edges: Venezuela's Community Councils. NACLA Report on the Americas 42 (3): 11-14.

Ewart, Elizabeth. 2013. Space and Society in Central Brazil: A Panará Ethnography. New York: Bloomsbury Academic.

Golub, Alex. 2014. Leviathans at the Goldmine: Creating Indigenous and Corporate Actors in Papua New Guinea. Durham/London: Duke University Press.

Gow, Peter. 1989. The Perverse Child: Desire in a Native Amazonian Subsistence Economy. Man 24 (4): 567-582.

Harris, Olivia. 2000. To Make the Earth Bear Fruit: Essays on Fertility, Work and Gender in Highland Bolivia, ILAS Series. London: Institute of Latin American Studies. 
High, Mette. 2013. Polluted Money, Polluted Wealth: Emerging Regimes of Value in the Mongolian Gold Rush. American Ethnologist 40 (4): 676-688.

Kelly, José Antonio. 2011. State Healthcare and Yanomami Transformations: A Symmetrical Ethnography. Tucson: University of Arizona Press.

Kirsch, Stuart. 2014. Mining Capitalism: The Relationship Between Corporations and Their Critics. Berkeley: University of California Press.

Kopenawa, Davi, and Bruce Albert. 2013. The Falling Sky: Words of a Yanomami Shaman. Cambridge, MA: Harvard University Press.

Lauer, Matthew. 2006. State-led Democratic Politics and Emerging Forms of Indigenous Leadership among the Ye'kwana of the Upper Orinoco. Journal of Latin American Anthropology 11 (1): 51-86.

Li, Fabiana. 2015. Unearthing Conflict: Corporate Mining, Activism, and Expertise in Peru. Durham/London: Duke University Press.

Lizot, Jacques. 1991. Tales of the Yanomami: Daily Life in the Venezuelan Forest. Cambridge: Cambridge University Press.

- 2007. Yanomami. In Salud Indigena en Venezuela, Volumen I, ed. G. Freire and A. Tillett. Caracas: Ministerio de Salud.

McNeish, John-Andrew. 2012. More Than Beads and Feathers: Resource Extraction and the Indigenous Challenge in Latin America. In New Political Spaces in Latin American Natural Resource Governance, ed. Håvard Haarstad. New York: Palgrave Macmillan.

Nash, June. 1993. (1st ed. 1979). We Eat the Mines and the Mines Eat Us: Dependency and Exploitation in Bolivian tin Mines. New York: Columbia University Press.

Ødegaard, Cecilie Vindal. 2017. Alterity, Predation, and Questions of Representation: The Problem of the Kharisiri in the Andes. In Critical Anthropological Engagements in Human Alterity and Difference, ed. Bjørn Enge Bertelsen and Synnøve Bendixsen. London: Palgrave Macmillan.

Onneweer, Maarten. 2014. Rumors of Red Mercury: Histories of Materiality and Sociality in the Resources of Kitui, Kenya. Anthropological Quarterly 87 (1): 93-118.

Penfield, Amy. 2016. Maneuvering for Paper: Physical and Social Experiences of Bureaucracy in Venezuelan Amazonia. The Journal of Latin American and Caribbean Anthropology 21 (3): 457-477.

- 2017. Dodged Debts and the Submissive Predator: Perspectives on Amazonian Relations of Dependence. Journal of the Royal Anthropological Institute 23 (2): 320-337.

forthcoming. The Fuel of Fright and Force: Gasoline's Energetic Power and Its Entanglement within Human Composite Ethics. Journal of the Royal Anthropological Institute.

Ramos, Alcida R. 1994. The Hyperreal Indian. Critique of Anthropology 14 (2): $153-171$. 
Redford, Kent H. 1991. The Ecologically Noble Savage. Cultural Survival Quarterly 15 (1): 46-48.

Reig, Alejandro. 2013. "When the Forest World Is Not Wide Enough We Open Up Many Clearings": The Making of Landscape, Place and People among the Shitari Yanomami of the Upper Ocamo basin, Venezuela. PhD dissertation, University of Oxford.

Rival, Laura M. 2002. Trekking through History: The Huaorani of Amazonian Ecuador. New York: Columbia University Press.

Sallnow, Michael J. 1989. Precious Metals in the Andean Moral Economy. In Money and the Morality of Exchange, ed. Maurice Bloch and Jonathan Parry. Cambridge: Cambridge University Press.

Sawyer, Suzana. 2004. Crude Chronicles: Indigenous Politics, Multinational Oil, and Neoliberalism in Ecuador. Durham/London: Duke University Press.

Sax, Marieka. 2015. On Place, Well-Being and Illness in the Andes. Indiana 32: 47-64.

Shever, Elana. 2012. Resources for Reform: Oil and Neoliberalism in Argentina. Stanford: Stanford University Press.

Shipton, Parker M. 1989. Bitter Money: Cultural Economy and Some African Meanings of Forbidden Commodities. Washington, DC: American Anthropological Association Monograph Series.

Slater, Candace. 1994. “All That Glitters.”: Contemporary Amazon Gold Miners' Tales. Comparative Studies in Society and History 36 (4): 720-730.

Storrie, Robert. 2006. The Politics of Shamanism and the Limits of Fear. Tipiti 4 (2): 223-246.

Taussig, Michael T. 1980. The Devil and Commodity Fetishism in South America. Chapel Hill: University of North Carolina Press.

Taylor, Charles. 1997. The Politics of Recognition. In New Contexts of Canadian Criticism, ed. Ajay Heble, Donna Palmateer Pennee, and J.R. Struthers. Ontario: Broadview Press.

Valdivia, Gabriela. 2008. Governing Relations between People and Things: Citizenship, Territory, and the Political Economy of Petroleum in Ecuador. Political Geography 27 (4): 456-477.

Valencia, Cristobal. 2015. We Are The State! Barrio Activism in Venezuela's Bolivarian Revolution. Tucson: University of Arizona Press.

Walker, Harry. 2013. Wild Things: Manufacturing Desire in the Urarina Moral Economy. The Journal of Latin American and Caribbean Anthropology 18 (1): 51-66.

Whitehead, Neil L. 1999. Tribes Make States and States Make Tribes: Warfare and the Creation of Colonial Tribes and States in Northeastern South America. In War in the Tribal Zone: Expanding States and Indigenous Warfare, ed. R. Brian Ferguson and Neil L. Whitehead. Santa Fe: SAR Press. 
Wilde, Matt. 2016. Contested Spaces: The Communal Councils and Participatory Democracy in Chávez's Venezuela. Latin American Perspectives 44 (1): 140-158.

Wroblewski, Michael. 2014. Public Indigeneity, Language Revitalization, and Intercultural Planning in a Native Amazonian Beauty Pageant. American Anthropologist 116 (1): 65-80.

Open Access This chapter is licensed under the terms of the Creative Commons Attribution 4.0 International License (http://creativecommons.org/licenses/ by $/ 4.0 /)$, which permits use, sharing, adaptation, distribution and reproduction in any medium or format, as long as you give appropriate credit to the original author(s) and the source, provide a link to the Creative Commons license and indicate if changes were made.

The images or other third party material in this chapter are included in the chapter's Creative Commons license, unless indicated otherwise in a credit line to the material. If material is not included in the chapter's Creative Commons license and your intended use is not permitted by statutory regulation or exceeds the permitted use, you will need to obtain permission directly from the copyright holder.

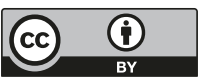




\title{
In the Spirit of Oil: Unintended Flows and Leaky Lives in Northeastern Ecuador
}

\author{
Stine Kroijer
}

Throughout the Americas, agroindustry, oil, gas, and mining projects have pushed the extractive frontier deeper into indigenous territories, more often than not with devastating social and environmental effects (Sawyer 2004, 2015; Bebbington 2012; Bebbington and Bury 2013; Hindery 2013). In northeastern Ecuador, exploration for oil began more than 40 years ago, when Texaco initiated operations in what was represented by the Ecuadorian state as an uninhabited, empty hinterland (Whitten 1978, 1981; Wasserstrom and Southgate 2013). Nonetheless, these 'empty' lands and forests were the home of the Cofán, Siona, Secoya, and Huaorani indigenous peoples. The intended and unintended consequences of oil exploitation-from contamination to colonisation and deforestation-have unavoidably led indigenous communities in the area to seek out their own strategies for coping and living their lives with oil. The chapter asks: how does a community uphold a sense of control over their lives in the encounter with extractivist policies?

\footnotetext{
S. Krøijer $(\bowtie)$

University of Copenhagen, Copenhagen, Denmark

e-mail: stine.kroijer@anthro.ku.dk

(C) The Author(s) 2019

C. Vindal Ødegaard, J. J. Rivera Andía (eds.), Indigenous Life

Projects and Extractivism, Approaches to Social Inequality and

Difference, https://doi.org/10.1007/978-3-319-93435-8_4
}

95 
This chapter is based on recurring fieldwork among the Ecuadorian Secoya, now self-denominated the Sieko-pai, a western Tucano-speaking people who live along the Aguarico River in the northwestern corner of the Amazon Basin (Vickers 1989a). When I first arrived in 2000, the community members in San Pablo Katëtsiaya, the largest of four Secoya villages in Ecuador, were already well acquainted with oil exploitation, and several elders figured among the plaintiffs in the ongoing international lawsuit against Chevron-Texaco for the contamination caused during their operations in the area during the 1970s and 1980s (Kimerling 1993; Sawyer 2001, 2004, 2015; Barrett 2014). I was interested in understanding how these experiences, and other past encounters with powerful 'others,' were brought to bear on their ongoing talks with Occidental Petroleum Company, a US-based oil company, which at the time held the rights to exploit resources below Secoya territory (Krøijer 2003, 2017). Over the next many years, I worked with the Secoya indigenous organisations in Peru and Ecuador on a binational land rights claim which would enable them to (re)establish a continuous binational territory in a border area historically torn by war, colonisation, and the effects of the rubber boom in the Upper Amazon (Casement 1913; Hardenburg 1913; Taussig 1987; Vickers 1989a; Santos-Granero and Barclay 2002; Wasserstrom 2014). When I returned again for long-term fieldwork in 2014-15, the Secoya were in talks with a Chinese-owned company, Andes Petrol Ecuador Ltd, which was bent on drilling two exploratory wells in the immediate vicinity of San Pablo Katëtsiaya. A longitudinal perspective has enabled me to appreciate how the Secoya, sometimes in seemingly contradictory ways, do their best to retain a sense of control and self-determination in a world of profound transformations and how, in such contexts, it becomes the work of shamans and local leaders to control unintended flows and transformations (see also Krøijer 2017).

This chapter takes its conceptual point of departure in the Secoya word for oil, wëhue - literally breach or leak in pai-koka —a linguistic and conceptual invention born of oil exploitation. I take the leaky quality of oil as my analytical lens for questioning the widespread academic and political discourse about extractive enclaves by which extractive industries carve out spaces of sovereignty in independent states (Ferguson 2005; Bebbington 2012; Guzmán-Gallegos 2012). This notion has been employed by companies to suggest that their impacts can be spatially contained (see Hindery 2013). I show how resource extraction ties into the Secoya's view of the cosmos as being in constant transformation; hence, how leaky matters and 
uncontrolled flows become matters of special concern. In so doing, the chapter speaks to an ongoing theoretical debate concerning the alleged 'essentialism' of the ontological turn in anthropology (Heywood 2012; Pedersen 2012; Bessire 2014; Vigh and Sausdal 2014; Cepek 2016; Holbraad and Pedersen 2017) and how the concern for ontological questions in the context of resource extraction is sometimes-mistakenlytaken as an argument for the claim that oil is a spirit for (at least some) indigenous peoples in the Ecuadorian Amazon (Cepek 2016). Rather than taking this mistaken perception as the point of departure for a critique of an anthropological interest in ontological questions (see Cepek 2016), I argue that oil is dealt with in the spirit of oil, namely as a matter of uncontrolled transformation. The leakiness of oil is, in other words, the only essence at stake. Analogous to Pedersen (2014), I show how unintended flows and transformations are dealt with through diverse strategies of containment and control. It is through attempts to steer, contain, and control leaky material flows around resource extraction that the Secoya carve out a space of self-determination on their land.

\section{Oil and Leaky Enclaves in Ecuador}

In 1964, the Texaco-Gulf Consortium obtained a 40-year contract to an area covering approximately 1.5 million hectares in northeastern Ecuador. Between 1972 and 1991, the company produced more than 1.4 billion barrels of crude oil from 238 wells; when this cornerstone of 'modernization and development' left the country in 1992, more than 600 open-waste pits were left behind (Kimerling 1993: 21-22; Sawyer 2001: 162) leaking crude oil and toxic production water into waterways. When the Secoya were moved to their current location by the Summer Institute of Linguistics (SIL) in 1973 (Vickers 1989a), they saw the area as an unending, fertile, and abundant forest (ibid.; Krøijer 2017), but soon they would find themselves in the frenzy of oil exploitation. Most of the adult Secoya men were hired by Texaco for clearing a grid of seismic paths cutting through the forests as well as for other manual labour. Families would frequently receive gifts and food—such as rice, sugar, and cooking oil—from company workers passing through San Pablo to enable the frictionless access and uninterrupted presence of the company (Krøijer 2003). Texaco called their policy for community relations 'the good neighbour,' implying that they had no formal obligations to the indigenous inhabitants in the area but intended to develop friendly relations with the population (Wray 2000: 46). 
Apart from the military garrisons, the Ecuadorian state had little presence in the zone during the 1970s, but delegated the role of spearhead of civilisation and development to Texaco and to the missionaries from SIL who had settled in the village. The evangelical missionaries, together with Texaco, were the only institutional interlocutors who mediated the Secoya's access to desired goods from the outside. At first glance, therefore, Texaco's activities in Ecuador lived up to standard definitions of an enclave economy, in reality operating as a state within the state (Weisskoff and Wolf 1977; Ferguson 2005; Hindery 2013). This not only undermines the government's ability to foster inclusive development for its population but also erodes indigenous peoples' sense of territorial sovereignty and self-determination (Wray 2000; Bebbington 2012; Guzmán-Gallegos 2012) as they only have limited influence on the extractive activities taking place on their land. ${ }^{2}$ Even though the Secoya hold territorial rights, this right does not include property rights to subsurface resources, which across the world and with few exceptions belong to the nation-state but can be licensed to private companies.

In the 1970s, however, Ecuador saw a first surge of resource nationalism, headed by successive military governments which reclaimed state ownership over underground resources, established a state oil company, and renegotiated contracts to gain more control over the booming oil sector. Texaco's contract was cut to 20 years and the concession reduced to approximately 500,000 hectares (Wray 2000; Gordillo García 2005; Perreault and Valdivia 2010; Rosales 2017). While Texaco's oil production generated a profit of approximately USD 25 billion over a 20 -year period, the Amazon region became strategically important to the national economy. Oil exports for decades covered up to 50 per cent of the state budget (Wray 2000: 24), but for local inhabitants such as the Secoya, living around production sites and along contaminated waterways, oil production had few tangible benefits. As histories from this period attest, the Secoya felt taken by surprise, overwhelmed and abandoned by the state; the effects were experienced as a threat to their physical existence. This sense of threat was epitomised by the 1987 earthquake that caused a pipeline rupture which turned the Aguarico River black with oil and heavily impacted riverine life. Inexperience with contamination caused several human deaths from drinking or bathing in the river (Krøijer 2003, 2017).

In response to colonisation and increased pressure on the land, which to the Secoya continue to be some of the most troublesome effects of oil exploitation and associated infrastructure development, the Siona and 
Secoya formed an organisation in 1976 demanding territorial rights along the Aguarico and Cuyabeno Rivers. ${ }^{3}$ To embark on this process, they had to seek out new allies, as the local representatives of SIL 'did not see it as their role to help us in politics,' as a Secoya leader would later explain. Over the coming years, the Organization of the Siona and Secoya of Ecuador (OISSE, later OISE) joined forces with the nascent national indigenous movement (Vickers 1989b). At first, the Secoya only gained land rights to a small plot of land around the village of San Pablo, as they were considered to be peasants, but, by 1990 , the land title was expanded to 42,614 hectares (NASIEPAI 2014: 28).

In 1993, the Secoya joined a class action lawsuit against Texaco, which was filed in New York, to hold the company accountable for the devastating effects of oil exploitation. The state oil company, PetroEcuador, took over the production of the Sacha and Shushufindi oil camps closest to Secoya territory as well as the neglectful industrial practices, and much of the following legal battle has concerned who was in fact responsible for the undeniable contamination. So far the Secoya have seen little compensation, but contrary to the academic preference for histories about either heroic resistance or total devastation (Cepek 2009), it must be observed that the profound transformations of the environment and social life did not prevent them from acting on their situation. Even though the Secoya never resisted oil exploration, or saw it as within their power to prevent further oil development, they have continuously tried to steer the transformations and continuously engaged in dialogue and consultation processes with the stream of companies that have explored for oil on their land during the past 40 years. These companies have demonstrated increasing interest in engaging indigenous peoples in 'participatory processes' (cf. Li 2015).

In light of the above, the enclave metaphor, if applied in the context of oil exploitation on indigenous land (Guzmán-Gallegos 2012), can wrongly give the impression that the production and its effects are contained. The concept is appropriate insofar as the Ecuadorian government transfers the right to explore for oil within a concession to a private company, that is, to a bounded area that neither corresponds to indigenous concepts of territoriality nor to the administrative boundaries within states (ibid.: 162). It is equally or even more relevant, however, to understand how such enclaves leak, as onshore production sites are almost never completely separated from ongoing life in local and indigenous communities, who do their best to govern the material spill-over - for example, of money, gifts, and contamination-as 
well as other, unintended effects. As argued by Ødegaard in her chapter on Peruvian contrabandistas (this volume), people may redirect such flows or engage them in other life-making projects.

To appreciate the efforts at containing and steering flows from enclaves, it is worthwhile to look briefly into the Secoya's second major encounter with a US oil company. In the mid-1980s, new possibilities for foreign investments were opened in the oil sector in Ecuador (Perreault and Valdivia 2010: 691) and, between 1985 and 1995, the Ecuadorian Ministry of Energy and Mines held eight rounds of competitive tendering among foreign companies (Wray 2000: 29). Occidental Petroleum and Production Company (Occidental) took over a concession known as Block 15 , in 1985, but the Secoya knew little of this bureaucratic transfer until 1996, when a team of researchers preparing the environmental impact study made their appearance in their midst, backed by soldiers from the military and a strong community relations team, which intended to 'work the needs' of the Secoya communities to secure their signature on a contract allowing all future oil activities on their land (Vickers 1998; Krøijer 2017: 11). Occidental repeated Texaco's 'good neighbour' slogan in the title of their community relations strategy. At first, the team did its best to 'work the divisions' between Secoya families and between communities by offering money to individuals (cf. Guzmán-Gallegos 2012) and threating with expropriation of the land. Nevertheless, Occidental soon had to realise that the Secoya had become better organised, which played out not only as having better knowledge of their rights but also as better access to counselling and ability to control and formalise the interactions between company and community representatives.

Through several rounds of negotiations in Quito concerning the topographic, seismic, and exploratory phases of oil exploitation, the Secoya managed to negotiate compensations that they were largely satisfied with. Apart from the compensation funds, the signing of a Code of Conduct (OEPC 2000), which regulated the procedures of the negotiation process, was of particular importance to the Secoya. According to this, the company was only entitled to approach the communities through meetings with a dialogue committee appointed by the general assembly of the Secoya organisation. Later, when production went into the exploratory phase, the Code of Conduct also regulated the presence and movement of workers within the territory; they could not build new roads, come close to human settlements, or physically leave the oil camp in any way, and both equipment and personnel had to be moved to and from the oil platforms 
by helicopter. With the assistance of a lawyer from the Confederation of Indigenous Nationalities in Ecuador (CONAIE) and biologists from an Ecuadorian NGO, the agreements were monitored carefully. The Secoya also formed their own monitoring group with support from the NGO, which went to the platforms on a regular basis to perform inspections and take water samples from the surrounding creeks and streams. The intended seclusion was not always upheld in practice-hunters would sometimes sell game to the camp kitchen, there were stories of women having love affairs with workers, and after long periods of rain where the helicopter could not access the platform, workers would sometimes be allowed to walk to the nearest village to be transported away by boat-but on the whole the process reinforced a sense of being at least in partial control of events. What caused most upheaval was the flow of money, especially OISE's decision to distribute the compensation directly to all Secoya families. Some invested in education or in small businesses, but it also enrolled some community members in a personalised boom-and-burst economy: drinking, haphazard purchases, and daring economic ventures, which at least on one occasion distorted the sense of shared ownership of the land, creating quarrels and ongoing internal disputes, which only abated long after Occidental failed to find commercially sound quantities of oil, the exploratory wells were sealed, and the source of money ran dry (Krøijer 2003).

Today, Ecuador presents a valuable opportunity to reevaluate the idea of enclave economies. First, the emergence of a 'neo-extractivist' government led by President Rafael Correa has again increased the state's role in extraction as well as the investments of revenues in infrastructure and (in a more) inclusive development (Perreault and Valdivia 2010; Gudynas 2014). In the Secoya's view, this turn of government has only to a limited extent benefited them; they were, moreover, displeased with the decision to revoke Occidental's licence in 2006, after the company was accused of having transferred part of its oilfield to another company without government authorisation. ${ }^{4}$ Even under the New Left, sites of extraction often continue to be characterised by weak state presence, though my more recent fieldwork on northeastern Ecuador also shows that there is a growing recognition among the Secoya of the state as a key interlocutor in resource extraction (cf. Reider and Wasserstrom 2013). Second, regardless of state presence, companies are no longer unfettered in their efforts to reconfigure territories for capital accumulation, nor are production sites secluded from or unconnected to the surrounding world. As the above examples illustrate, production sites not only produce leaky substances, 
such as oil and contaminated production water, but money also 'leaks' and generates its own intended and unintended effects, as they are entangled in different and often awkward forms of collaboration (cf. Li 2015; Tsing 2005). These relational flows reconfigure the socio-environmental landscape but are also intersected both by the company's and the indigenous peoples' strategies of containment and control. Hence, the concept of 'enclaves' often seems to enclose the analysis itself by supposing seclusion and can become a political shield against furthering an understanding of how leaks produce new realities. The Secoya's word for oil, to which we shall now turn, has the quality of highlighting instead its leaky and transformational effects.

\section{LEAKY REALITIES}

We are sitting on the narrow porch outside Manatí's house on the bank of the Aguarico River discussing the plans of a Chinese-owned oil company, Andes Petrol Ecuador, to drill two exploratory oil wells in the immediate vicinity of San Pablo Katëtsiaya. Besides Manatí, who is the son of a late reknown shaman, Manatí's son Alberto and his grandson Hugo also participate in our conversation, which was sparked by a recent meeting in the Secoya organisation.

During the meeting in the small, shed-like office of the organisation, community members had gathered to see if they could reach a consensus on how to act. The condition of the office with its scattered white plastic chairs stood in stark contrast to the sea of new motorcycles and pickup trucks parked outside, most of which belonged to community members and were purchased with compensation money paid in the past. Most participants turned out to be in favour of Andes Petrol's plans, expressing anticipatory hopes for the benefits oil exploitation would bring in terms of jobs and monetary compensation. There were concerns, however, about the closeness of the wells to the village and the ability of the leaders to 'negotiate well,' as the company was again seen as trying to push through a fast and relentless 'consultation' process. In such meetings memories of Texaco were evoked to warn against the negative consequences of oil exploitation. Part of the meeting also consisted in a report back from the Ecuadorian lawyer in the Chevron-Texaco lawsuit, which had been shifted from the court in Lago Agrio, the centre of Texaco's Ecuadorian adventure, to Den Haag in Holland, and from there on to Canada and Argentina, where the plaintiffs hope to lay claim on Chevron's assets. Several Secoya 
elders were still part of the group of plaintiffs, but that did not prevent the organisation from simultaneously engaging in negotiations over new oil activities on their land. Some people attending the meeting expressed that they would be unable to prevent the plans of Andes Petrol because, as they rightly observed, the government had already received Chinese loans, which were to be repaid with oil deliveries. They might as well get the best out of it, they reasoned. And few could deny that many families were in dire need of an income, as most were unable to survive on subsistence agriculture and hunting in what was described as a territory marked by increasing scarcity.

Manatí and his extended family did not favour further oil exploitation. While looking over the river, Manatí vividly recounts how they got exhausted from the work journeys during the land delimitation process in the mid-1990s. Little did they know, he said, that they would not just be able to 'go someplace else' when the land got depleted as 'the forest was by now full of other people.' Hugo, Manatí's grandson, Hugo's wife Lucía, and their children were now among the young families who did not have use of the agreed 100 hectares for gardening as the previous generations had, due to population increase and scarcity of land. Most Secoya living in and around San Pablo relied almost entirely on purchased foods, especially rice, canned fish, oil, and sugar for their daily subsistence. Also, this afternoon, Manatí would complain that the territory had grown empty (poe'say'yo), with barren patches, little life, and few animals to hunt. The felling of the large slow-growing trees also meant that the wati (spirits or forest-beings) had abandoned the area around San Pablo and moved further away (Krøijer 2017). Contrary to the state's representation, in the 1960s of the Amazonian lowland as barren and ripe for colonisation, its new emptiness, in Manatí's optic, was full of people.

Some ten years ago, Manatí, his daughter, and a few other relatives had resumed the drinking of yagé (ayahuasca) on a regular basis, which had been banned by the SIL as well as the converted, evangelical community members, who also happened to hold the leading posts within the indigenous organisation. The death of Manatí's father, the renowned inti'ba'ikë (shaman-leader) Fernando Payaguaje (1994), had led to a situation of 'shamanism without shamans' (Brunelli 1996; Langdon 2016), and several community members tied the lack of animals to the lack of an able inti'ba'ikë to attract the game. Now, the drinking of yagé had become a modest source of income from international tourists and middle-class 
Ecuadorians who wished to use the hallucinogenic brew in what they consider to be their spiritual self-discovery. Moreover, the regular drinking of yagé had also enabled Manatí to resume the transiting of perspectives and exploration of the cosmos which his own father had been so famous for. While living in the house of his family, I had tapped into this knowledge about forest-beings in connection to a research project on the political lives of trees (Krøijer forthcoming). The shamanic practices of the Secoya share important features with other indigenous groups in the Amazon Basin (Viveiros de Castro 1998). This involves seeing all beings of the forests as persons, which the shaman, according to Manatí, 'is able to go visit' in order to 'live like they do' through the bodily metamorphosis assisted by yagé. Through bodily transformation, the shaman taps into the knowledge of these beings and comes to understand how the cosmos is 'essentially' transformational (Krøijer 2017).

'What is the word for oil in pai-koka?' I ask Manatí while leaning against the wall of his house, where the former bright pink painted walls were now peeling; suddenly realising that even though I had taken an acute interest in Secoya negotiations with oil companies, since my first fieldwork in 2000, I had never asked that question. 'Wëhue,' Alberto replies, and continues:

\begin{abstract}
Today we use the term nea wi'yape for the aceite [oil] that you buy in containers, the one that you use for mixing with gasoline for outboard motors, but this is a new word. We also still use the term wëhue, which means breach [derrame] or something that leaks.
\end{abstract}

'Did the Secoya know of oil before Texaco?' I continue my enquiry, 'did your father Fernando or other shamans see oil in their yagé visions?' I ask Manatí, who is considered to be the one most acquainted with his father's knowledge. 'Did the inti'ba'ikë know there was a layer of oil in the underground?' I add. Manatí answers no to all my questions and explains they did not know anything about oil before they heard of Texaco and the company started spilling (derramando) oil into their forest and rivers. He also rejects the suggestion that oil should be a wati (a spirit or being) or connected to their agency in any way. While rejecting the idea that oil possesses a form of agency comparable to human beings like other forest- and water-beings do (Vickers 1989b; Krøijer forthcoming), my constant questioning nonetheless compels him to tell the story of the Hikomo-pai, the people with tails who, according to Secoya mythology, live underground. 'As you know,' Manatí begins, 
the Sieko-pai emerged from a hole in the ground near Jupo. There were different people living in the underworld, and the Sieko-pai was living farthest inside the ground [away from the entrance hole]. One day, Nañë [the moon, celestial being involved in the creation of all things] is walking along a forest trail and suddenly he saw a person [pai]. The pai is collecting ya'i [a liana], dragging it behind him into the cave. Nañë steps on the liana, the person keeps pulling from the inside, but then comes out to see why he cannot drag the liana into the hole, if it somehow got stuck. Nañe hides behind a tree, while the pai clears the path and enters to try again. Nañë steps on the liana again and the pai comes out and there he encounters Nañë. "Why are you stepping on my liana, do you want to entrap me?" he asks. "Why are you carrying this liana?" Nañë replies with a counter question. "I am taking it to tie a basket over the fire to smoke chontaduro [palm fruit]," the pai replies. He shows his chontaduro to Nañe, but what he pulls from the basket is not chontaduro, but mud cakes. Nañe looks at it with disgust and says, "This is not chontaduro. I will give you chontaduro." Nañë brings chonta from the forest for him to try. Then all the people living underground get curious; they want to try it too and start coming out of the cave in the ground. They are not Sieko-pai; they have tails, but as they exit Nañë pulls off their tails [and transforms them into various beings of the forest]. Different pai come out, but because we were the furthest back, it was our turn last. A menstruating woman was among the first to appear. She was spilling [derramando] blood on the ground. When he saw her, Nañë got so mad that he transformed her into a deer and hurried to close the hole behind her.

'That is why we are so few,' Manatí ends the story, and adds, 'The hikomo-pai are still living in the underground; they live like Sieko-pai going about their daily activities.' During most of the storytelling, I was only paying partial attention as I had heard it many times before. In this version of the story, however, Manatí was speaking slower and with more emphasis when he reached the last part about the menstruating woman, the spilling of blood, and the disastrous consequences it had for the Secoya. It is considered customary not to hunt or eat the wild deer even though this taboo is seldom upheld anymore, and as Manatí's daughter has once explained, women were seldom held in full seclusion anymore, apart from during the first menstruation and the first day of the menstruation cycle. But what intrigued me most was why he was telling the story in the context of a conversation about oil and oil exploitation on their land. Was it an old man's attempt to get the conversation back on a track that he was surer about or how did the story about the hikomo-pai relate to the question about oil as breach? 
Environmental activist groups in Ecuador have, in the case of the neighbouring Cofán, suggested that oil is the blood of the subterranean Coancoan. This has been used in public campaigning to argue against further oil exploitation by pointing to the catastrophic effects for Cofán life and cosmology (Cepek 2016). Based on Cofán stories about the Coancoan, and the humour and doubt with which the stories are delivered, Michael Cepek convincingly argues in a recent article that to the Cofán the Coancoan pertains to a different realm than contemporary oil exploitation. Rather, according to Cepek, casting the extermination of underworld beings as a consequence of oil exploitation generates a 'sympathetic form of romanticising attention' in public campaigning (ibid.: 623; see also the chapter of $\mathrm{Li}$ and Paredes in this book). Likewise, nothing in Manatí's story about the hikomo-pai, and his comments on the matter, suggest that oil is the blood of the hikomo-pai. The hikomo-pai are-in the knowledge of the Secoya inti'ba'ikë (or shamans, if you will)-the only beings with human-like capacities and forms of life dwelling in the underground, and they have no direct relation to or interaction with oil.

Cepek uses his findings to highlight the pragmatic and epistemological character of the Cofán's discourses about oil as a stepping stone to critique the 'ontological turn' and cosmopolitical research in Latin America, which is accused of reifying and romanticising indigenous struggles. According to Cepek, researchers interested in ontological questions are 'steamrolling the subtleties of their data' and 'constructing a single, homogenized and exoticized conceptual perspective' by not maintaining a relationship to 'accurate ethnography' (ibid.: 624-25). While I agree with the author's conclusion regarding the erroneous characterisation of oil as blood of subterraneous beings, I doubt that it constitutes sufficient grounds for discarding all ontological questions regarding oil as romanticising, or even problematic.

Let me return to Manatí's story and our conversation on the porch. The emphasis on the blood spilled on the ground in the context of a conversation about wehüe (oil as breach and leak) is telling. Among the Secoya-as among many other indigenous peoples of the Amazon basin-the management of menstrual blood and other bodily fluids is considered a delicate process, where the flow between the body and the world has to do with fertility and societal well-being and with managing cosmological insights (Seeger et al. 1979: 11; Belaúnde 2008: 19). In some Amazonian societies, blood is associated with vitality and strength, but more than anything, blood circulates, and this is the source of its properties (ibid.: 38). 
In Secoya communities, blood must be controlled through practices of abstention and seclusion (Belaúnde 2008), though as mentioned before, this is not always strictly followed in practice. A person must control his or her bodily fluids, sometimes with the support of shamans whose power is furthermore essential for securing the flow of game, resisting spirit attacks, and associated sicknesses. Spilled blood can attract dangerous beings such as the jaguar, just as people are attracted by the smell of chicha (ibid.). In my view, therefore, Manatí's story speaks to how oil-which has the property of leaking, flowing, and spilling as the word in pai-koka suggestsmust be contained and controlled like menstruation blood. It is the leakiness of oil (and menstrual blood) that is the only ontological 'essence' at stake. The analytical challenge is, in other words, not to grasp what oil 'really is' (e.g. blood), as a substantivist understanding of the concept of ontology would envisage; rather, it is a point of departure for a new way of thinking about oil: Unintended and uncontrolled flows can, in the case of both oil and of blood, have disastrous effects, as the story's ending with the limited number of Secoya on the surface of the Earth aptly illustrates. It follows that the real matter of concern, especially to inept shamans, as Manatí often refers to himself, and young leaders is how to contain and control such flows. Leaders of indigenous organisations face the difficult task of steering and controlling the flows and unbound qualities of contemporary oil development in Amazonia.

\section{Controlling Unintended Flows}

In the meeting preceding our conversation on the porch, the negotiation strategy vis-à-vis Andes Petrol and the state oil company was hammered out. The pros and cons in economic, political, and existential terms were carefully evaluated (cf. Krøijer 2003). For the first time, wells in the immediate vicinity of where people were living was a likely scenario, and this was not taken lightly. The hope was to ensure a stable flow of money, but avoid the undesired social and environmental effects, including that of having oil workers present in the village all the time.

In the breaks during the meeting, however, people gathered in smaller groups to discuss a series of conspicuous incidents involving the disappearance of outboard motors along the river. When I first conducted fieldwork in this area in 2000, few families owned outboard motors, and it was often necessary to wait for hours or an entire day to catch a lift along the river with a motorised canoe. After accruing compensations from Occidental, 
most families bought at least one motor, which increased traffic on the river significantly. As Hugo jokingly commented, this resulted in the Secoya 'forgetting how to walk' and old paths grew over. But within the second half of 2014, at least 25 motors were stolen, mainly at night, and this was a prime issue of conversation and speculation during gatherings. Hugo had lost one motor, and his aunt, living within the group of houses of their extended family, claimed to have seen a suspicious black canoe steered by a man in a black tunic. The police had little success in their investigations, not doing much apart from patrolling the river accosting people who did not wear a lifejacket in their canoes. Instead of relying on the police investigation, people exchanged views on possible strategies of prevention and containment. Manatí's son-in-law had tied a fierce dog to a pole at the river bank and placed two big lights that illuminated the river at nighttime, to prevent more thefts. The general feeling at the meeting was that it was either Colombians, maybe acting in collusion with the police supposedly investigating the matter, or a bai'ho'wati, the spirit of a particular dead shaman, recognisable because he would usually wear a black tunic, had a bald head, and used a crown made from the ma'so bori flower. According to Manatí, a bai'ho'watí is the most dangerous among spirit-beings as an attack results in almost certain death. Only a strong shaman can repel such an attack from a powerful other, and the Secoya didas everybody knew-no longer count with strong shamans, to which the scarcity of hunting game around San Pablo was also taken as a witness (Krøijer 2017). In this case it was luckily only property being lost, but the discussions over the theft of motors were followed by calls for a stronger 'government' and produced stories about how past shamans had the strength to break and deflect the attacks by foreign shamans. The ongoing speculations at the meeting and beyond made clear how the main concern was with the control of intended and unintended flows of materials and substances that come to leak across the socio-environmental landscape in unintended ways, and it was evident that this concern does not only pertain to some mythic realm but plays out also in relation to contemporary forms of extractivism.

Andes Petrol had two wells in production in an area near another community mostly inhabited by Secoya families that have intermarried with lowland Quichua. According to the oral reports from that village, the construction and oil production was the cause of heavy sedimentation in two small rivers that the community relied on for fishing. Andes Petrol had called for a meeting regarding the new wells the week before, and 
members of their team of community relations had been hanging around the village for cultural events. 'They call themselves our good friends,' Hugo commented with a smile and explicit reference to the Occidentals' 'good neighbour' strategy, 'now I wonder what they mean by that,' he would jokingly comment, not being convinced by their display of good intentions. The president of the Secoya organisation had already sent a letter of complaint to the relevant ministry, demanding that they be appropriately consulted in accordance with ILO Convention no. 169, which had been ratified by Ecuador already in connection to the constitutional reform in 1998. Nonetheless, other members of the community were worried that he might feel tempted to enter into a contract with the company without their knowledge.

Various strategies to steer the flow of money and oil were proposed: one historic leader, who had been involved in forming the first Secoya organisation OISSE but was later accused of spending communal money from Occidental on his own economic ventures, argued at the meeting that the flow of money from companies was too unstable to rely on: 'They drop on us from time to time,' he said in Spanish, 'but then everything returns the same. We become as poor as we were before.' According to him, this had happened in his own case, as the cattle he purchased with money from Occidental had to be slaughtered due to the spread of foot-and-mouth disease and the land around his house was reduced to barren pasture.

He explained that at the time of the missionaries, his father would receive money for work he did for them, but the money was of no use to him. 'Now we never have enough money,' he continued. In his view, the negotiations with Andes Petrol and the state should not be about reparation and compensation; first of all, they needed to 'tell the state how we wish to negotiate with them' and the aim should be 'to participate in all phases of exploration and exploitation, so they pay a direct tax to the community.' This would not only secure a stable flow of money but also more control of the flow. Nevertheless, this strategy did not take environmental damage, land scarcity and degradation into consideration.

To negotiate well, the organisation had armed itself with two US lawyers, remunerated by a new indigenous NGO that is partially funded by the Leonardo DiCaprio Foundation. Where Ecuadorian environmental NGOs had long ago written of the Secoya as too supportive of oil exploitation, these new powerful outsiders were embodying the promise of gaining more control of the process. The two advisors had read the 550-page-long Environmental Impact Study prepared by Andes Petrol, 
and the conclusion they reached was that the report downplayed a number of likely negative impacts. In addition to the letter of complaint regarding the right to consultation, the advisors would prepare another letter to the Ministry of Environment to refute the conclusions and ask for further investigations to be conducted. These two measures would at least buy the Secoya some time to agree among themselves and negotiate the next steps in Andes Petrol's plan.

Not all were equally happy, including the members of Manatí's extended family who, outside the meeting, expressed concerns about the future of the forest but often kept quiet during meetings. Hugo, who was about to finish a university degree, had been bestowed with his grandfather's legacy and received his instruction since childhood. Even though Hugo was not a regular yagé drinker, he described his role as being 'to follow the path of the laid out by his grandfather, through the yagé visions,' but in his own way. Already before ending his university education, he had become the coordinator of the abovementioned indigenous NGO, which mainly comprised young university-educated men and women from the Siona, Secoya, Cofán, and Huaorani nationalities. They want 'to see things done differently,' as Hugo phrased it. The new indigenous NGO was in an ambiguous if not strained relationship with the Secoya organisation and the other representative indigenous organisations, whose presidents were mainly from their paternal generation and from families that used to have closer ties to the Catholic and Pentecostal churches. OISE, which a few years ago changed its name again to NASIEPAI, was still the representative interlocutor on political issues vis-à-vis the state and private companies, but the new young leaders were better educated and were the ones counting on funding from the private climate fund of the famous US actor, Leonardo DiCaprio. In several cases, these new young leaders, such as Hugo, were younger kin of historic shaman-leaders' who often had seen themselves marginalised in the Ecuadorian indigenous movement since its growth to power in the 1990s. The challenge to that power is not only, now, coming from the outside, for example, from oil companies or political parties building alternative NGOs to foster internal divisions (cf. Guzmán-Gallegos 2012) but from within communities and from a new generation. Hugo had gained more presence in the conversations over oil exploitation and for the first time the land issue was placed on the table. Still, the strategy was not one of resistance, but one of delimitation and containment. 
As mentioned, the actual territory is too small to sustain the population, resources are depleted, and the Secoya have experienced a number of invasions of their territory, which the Ministry of Justice had not wished or been able to intervene in or resolve. Hugo suggested that the Secoya should demand land as compensation for oil development and, moreover, that they should undertake a zonificacion, that is, delineate zones in their territory some areas were left untouched by oil development. This both entailed an adoption of modern discourses of forest management, and represented recognition of the fact that it is the state-and not the private companies - that is, the correct interlocutor in the consultation process over further oil development, but also expressed a strong desire to have a land free of oil extraction.

Several Secoya families had for the previous 15 years, with various levels of backing from OISE/NASIEPAI, pressed for the recognition of Secoya ancestral land in Largarto Cocha (Buwëya). This is a pristine river delta on the border between Ecuador and Peru, where the paiche, manatee, and river dolphins are still plentiful. Reclaiming this land would allow the Secoya to create territorial continuity between the Secoya on both sides of the border, but it had not been among the main political priorities of NASIEPAI. After the first demand presented to the Ministry of Environment ten years ago was turned down, based on the fact that the area is now a national park, the issue had not been consistently followed up on. In the meantime, the Peruvian Secoya, the Airo-pai, had gained rights to an extensive territory and established a new community literally on the border between the two countries. Now a generous grant from the Leonardo DiCaprio Foundation had renewed the hope of elders such as Hugo, who continuously talked of Buwëya as the place where he wished to spend his old age. After the meeting Hugo explained in detail:

The Company wants to work in the heart of the area we have for horticulture around San Pablo. This will end our life here. The territory will be without life. For that reason, we want a high-level dialogue with the government, in order for them to compensate us with territory in Buwëya. We are part of the territory and the territory is part of us, and if the territory disappears we will also be without life. We want a territory de'oyo pa'iye, as my grandfather says. This term implies that there is sufficient space to enable a free life, a bealthy territory without conflicts. Lagarto cocha is an alternative to us where you can feel all that [life], which has disappeared from around here. 
According to Hugo, the aspiration was to zone the territory in order to secure a 'healthy part' (una parte de'oyo pa'iye) and thereby allow a healthy flow between body, territory, and outside actors. It also reflects a realisation of the fact that different aspirations coexist among the Secoya and hence different ideas about what a healthy flow looks like. This is continuously rendered visible in the context of debates over further oil development: where some people cast the flow of oil as associated with a potential flow of money, compensation and future jobs, at least if controlled well by the leaders of the organisations, others see oil as the source of undesirable flows and uncontrolled effects. Hugo's rearticulation of the land rights claim and the call for zonificacion of the land within the debate over compensation can be seen as one such way to control and contain the undesirable flows, and to accommodate (in the spirit of oil) the conflicting interests and aspirations that almost always exist in indigenous communities.

\section{ConClusion}

To most indigenous communities in northeastern Ecuador the encounter with extractive industries, particularly oil exploitation on their land, is not a new thing. In this chapter, I have tried to describe how the Secoya, who have lived with oil development in the vicinity of their communities for more than 40 years, talk about and relate to oil or wehüe. I have found that their way of living with oil neither amounts to active and heroic resistance nor to passive acceptance of the conditions imposed on them from the outside. Instead, living with oil concerns the ability to control transformations and leaky flows of crude oil as well as contaminated production water, money, people, and other beings with their own inherent agencies and agendas, while making lives worth living.

In continuation of what I have argued elsewhere (Krøijer 2017), the Secoya seek to 'be flexible' in their encounters with the state, private companies, and other social groups. Being flexible is a strategy for upholding a sense of control and is also tied to the governance of the intended and unintended effects that are inevitably generated by oil exploitation in Amazonia. Whereas oil companies have gone to some lengths to convince the public that negative impacts can be spatially contained (cf. Hindery 2013) - a public argument that in Ecuador has been particularly prevalent in connection to oil exploitation in the Yasuní and in areas inhabited by 
indigenous groups considered to be in voluntary isolation through an argument about the use of tecnología de punta ${ }^{5}$ (Lu et al. 2017; Rival 2016)the concept of wehüe highlights oil's transgressive and transformative potential. Oil exploitation involves flows of oil and production water that sometimes leak into waterways, development of infrastructure and movement of people and workers, flows of goods and money-with potential desirable or undesirable effects - that inevitably leak from the so-called extractive enclaves. I hope to have shown how these leaky flows, which hold the potential for transforming the reality of Amazonian societies, are also the key matters of concern to indigenous groups such as the Secoya.

I have described some of the past and present internal debates about oil, which show that the Secoya do not consider oil to be the blood of subterranean beings, as a parallel ethnography of the Cofán and the subterranean Coancoan also illustrates (Cepek 2016), nor is oil considered a being with agentive qualities that surpass its leakiness. Oil is not a spirit, but instead dealt with 'in the spirit of' oil: oil, according to a Secoya shaman, should be handled as blood, namely as a substance that, if not contained and handled correctly, might disturb the healthy flow between body and territory and powerful 'others' such as states, private companies, jaguars, and spirit-beings (cf. Viveiros de Castro 2012). I have shown that it is probable that the Secoya establish an analogous relationship between oil, blood, and other unintended flows - such as outboard motors being stolen by unknown others-and consider that all such flows should be handled with equal diligence. By asking ontological questions of the material instead of assuming ontological essences, it is possible to appreciate how the only 'essence' of oil is its leakiness; pursuing its analytical implications can reveal the ways in which indigenous communities make their lives with, and in spite of, resource extraction.

Acknowledgements I am grateful to Matthias Borg Rasmussen for stimulating my thinking about resource enclaves. Some of the ideas presented here, I owe to him. I would also like to thank Piergiorgio Di Giminiani, Morten Axel Pedersen, Fabiana Li, the editors of this anthology, and the participants in the LASI Summer School 2018 in Chile for constructive comments and suggestions to earlier versions of this chapter. I thank the CIIR Centre (CONICYT/FONDAP/15110006) at the Pontífica Universidad Católica de Chile for hosting me during the writing process. The research has been made possible thanks to the Danish Council for Independent Research, grant no. 1321-00025B. 


\section{Notes}

1. The language of the Sieko-pai is called pai-koka (literally the language of people/humans). This language has been partly documented by the Summer Institute of Linguistics and the first bilingual Secoya teachers. As in most languages, encounters with new phenomena and changes of habits lead to the development of new words or concepts. Some of the new concepts and words in pai-koka can be found in Nacionalidad Siekopai (NASIEPAI) 2014.

2. Though generally adhering to self-identification as criteria-indigenous peoples in Latin America are generally recognised as the descendants of the precolonial inhabitants of the continent. The United Nation's Declaration on the Rights of Indigenous Peoples (2007) uses the expression of selfdetermination for Indigenous Peoples, but does not grant the right to form independent nation-states. As compensation, indigenous peoples may hold territorial rights within the state, the right to govern internal matters in accordance with their own institutions, and hold the right to be consulted on development plans and initiatives influencing their livelihood. The ILO Convention no. 169 was ratified by Ecuador in 1998, and the UN Declaration on the Rights of Indigenous Peoples was adopted into the new Constitution in 2008.

3. The Siona and Secoya have since the mid-1990s been considered two distinct indigenous peoples, but in Ecuador they have close marriage ties. Between 1942 and 1973, several families lived together in the Cuyabeno River. The majority of Siona today live along the Putumayo in Colombia, whereas the majority of the Secoya live along the Angusilla, Yubineto, Yaricaya, and Huajoya rivers in Peru. Both belong to the Western Tucanoan linguistic group. In the mid-1990s, the indigenous movement in Ecuador, CONAIE, encouraged identification as 'nationalities' (nacionalidades) to push for the recognition of Ecuador as a plurinational state. In this process, the Siona and Secoya, formed independent organisations.

4. There was extensive international news coverage of the 'expulsion' of Occidental from Ecuador, which was generally tied to the attempts of several New Left governments on the continent to 'nationalise' oil. See, for example: http://www.nytimes.com/2006/05/17/business/worldbusiness/17oil. html?mcubz=1

5. High-tech technology, which in the debate over oil exploitation in the Yasuní was claimed to mitigate negative environmental effects such as oil spills. 


\section{REFERENCES}

Barrett, Paul. 2014. Law of the Jungle: The \$19 Billion Legal Battle over Oil in the Rain Forest and the Lawyer Who'd Stop at Nothing to Win. New York: Penguin Random House.

Bebbington, Anthony. 2012. Social Conflict, Economic Development and Extractive Industry: Evidence from South America. London: Routledge.

Bebbington, Anthony, and Jeffrey Bury. 2013. Subterranean Struggles: New Dynamics of Mining, Oil, and Gas in Latin America. Austin: University of Texas Press.

Belaúnde, Luisa. 2008. El recuerdo de la Luna: Género, sangre y memoria entre los pueblos amazónicos. Lima: CAAAP.

Bessire, Lucas. 2014. Behold of the Black Caiman. Chicago/London: University of Chicago Press.

Brunelli, Gilio. 1996. Do Xamanismo aos Xamãs: estratégias Tupi-Mondé frente à sociedade envolvente. In Xamanismo no Brasil: Novas Perspectivas, ed. Esther Jean Langdon. Florianópolis: Editora UFSC.

Casement, Roger. 1913. British Bluebook. Correspondence Respecting the Treatment of British Colonial Subjects and Native Indians Employed in the Collection of Rubber in the Putumayo District. Presented to Both Houses of Parliament by command of His Majesty, July 1912.

Cepek, Michael L. 2009. The Loss of Oil: Constituting Disaster in Amazonian Ecuador. Journal of Latin American and Caribbean Antbropology 17 (3): 393-412.

- 2016. There Might Be Blood: Oil, Humility, and the Cosmopolitics of a Cofán Petro-being. American Ethnologist 43 (4): 623-635.

Ferguson, James. 2005. Seeing Like an Oil Company: Space, Security, and Global Capital in Neoliberal Africa. American Anthropologist 107 (3): 377-382.

Gordillo García, Ramiro. 2005. ¿El Oro Del Diablo? Ecuador: Historia Del Petróleo. Quito: Corporación Editora Nacional.

Gudynas, Eduardo. 2014. Extractivismos: Ecología, economia y politica de un modo de entender el desarrollo y la Naturaleza. Lima: RedGE.

Guzmán-Gallegos, María Antonieta. 2012. The Governing of Extraction, Oil Enclaves, and Indigenous Responses in the Ecuadorian Amazon. In New Political Spaces in Latin American Natural Resource Governance, ed. H. Haarstad. New York: Palgrave Macmillan.

Hardenburg, Walter E. 1913. The Putumayo: The Devil's Paradise: Travels in the Peruvian Amazon Region and an Account of the Atrocities Committed upon the Indians Therein. London: T. Fisher Unwin.

Heywood, Paolo. 2012. Anthropology and What There Is: Reflections on "Ontology". Cambridge Anthropology 30: 143-151. 
Hindery, Derrick. 2013. From Enron to Evo: Pipeline Politics, Global Environmentalism, and Indigenous Rights in Bolivia. Tucson: University of Arizona Press.

Holbraad, Martin, and Morten Axel Pedersen. 2017. The Ontological Turn: An Anthropological Exposition. Cambridge: Cambridge University Press.

Kimerling, Judith. 1993. Crudo Amazonico. Quito: Abya Yala.

Krøijer, Stine. 2003. The Company and the Trickster: A Study of Secoya Storytelling as a Mode of Government. Master's thesis, Department of Anthropology, University of Copenhagen.

- 2017. 'Being Flexible': Reflection on How an Anthropological Theory Spills into the Contemporary Political Lives of an Amazonian People. Tipiti: Journal of the Society for Lowland South America 15 (1): 46-61.

Langdon, Esther Jean. 2016. The Revitalization of Yajé Shamanism Among the Siona: Strategies of Survival in a Historical Context. Anthropology of Consciousness 27: 180-203.

Li, Fabiana. 2015. Unearthing Conflict: Corporate Mining, Activism and Expertise in Peru. Durham/London: Duke University Press.

Lu, Flora, Gabriela Valdivia, and Néstor L. Silva. 2017. Oil, Revolution, and Indigenous Citizenship in Ecuadorian Amazonia. Chicago: University of Illinois Press.

Nacionalidad Siekopai (NASIEPAI) and Gobierno Autónoma Provincial de Sucumbios. 'Plan de Vida Siekopai 2014-2029.' 2014. (unpublished).

Occidental Exploration and Production Company (OEPC). 2000. Convenio para la fase de exploración petrolea en el territorio de la nacionalidad Secoya. (unpublished). http://isis.hampshire.edu/amazon/oil/agree_span.html. Accessed 15 Nov 2017

Payaguaje, Fernando. 1994. In El bebedor de yagé, ed. Miguel Angél Cabodevilla. Quito: CICAME.

Pedersen, Morten Axel. 2012. Common Nonsense: A Review of Certain Recent Reviews of the 'Ontological Turn.' Anthropology of This Century 5. http:// aotcpress.com/articles/common_nonsense/. Accessed 15 Nov 2017.

- 2014. Transitional Cosmologies: Shamanism and Postsocialism in Northern Mongolia. In Framing Cosmologies: The Anthropology of Worlds, ed. Allen Abrahamson and Martin Holbraad. Manchester: Manchester University Press.

Perreault, Tom, and Gabriela Valdivia. 2010. Hydrocarbons, Popular Protest and National Imaginaries: Ecuador and Bolivia in Comparative Context. Geoforum 41 (5): 689-699.

Reider, Susan, and Robert Wasserstrom. 2013. Undermining Democratic Capacity: Myth-Making and Oil Development in Amazonian Ecuador. Ethics in Science and Environmental Politics 13: 39-47.

Rival, Laura. 2016. Huaorani Transformations in Twenty-first-century Ecuador: Treks into the Future of Time. Tucson: University of Arizona Press. 
Rosales, Antulio. 2017. Contentious Nationalization and the Embrace of the Developmental Ideals: Resource Nationalism in the 1970s in Ecuador. The Extractive Industries and Society 4 (1): 102-110.

Santos-Granero, Fernando, and Federica Barclay. 2002. La frontera domesticada: Historia económica y social de Loreto, 1850-2000. Lima: Fondo Editorial de la Pontífica Universidad Católica de Perú.

Sawyer, Suzana. 2001. Frictions of Sovereignty: Of Prosthetic Petro-Capitalism, Neoliberal States and the Phantom-like Citizens in Ecuador. The Journal of Latin American Anthropology 6: 156-197.

- 2004. Crude Chronicles: Indigenous Politics, Multinational Oil and Neoliberalism in Ecuador. Durham: Duke University Press.

- 2015. Crude Contamination: Law, Science, and Indeterminacy in Ecuador and Beyond. In Subterranean Estates: Life Worlds of Oil and Gas, ed. Hannah Appel, Arthur Mason, and Michael Watts. Ithaca: Cornell University Press.

Seeger, Anthony, Roberto da Matta, and Eduardo Viveiros de Castro. 1979. A construção da pessoa nas sociedades indígenas brasileiras. Boletim do Museu Nacional, Série Antropologia 32: 2-19.

Taussig, Michael. 1987. Shamanism, Colonialism, and the Wild Man: A Study in Terror and Healing. Chicago: University of Chicago Press.

Tsing, Anna. 2005. Friction: An Ethnography of Global Connection. Princeton: Princeton University Press.

Vickers, William T. 1989a. Los Sionas y Secoyas: Su adaptación al medio ambiente. Quito: Abya Yala.

- 1989b. Traditional Concepts of Power Among the Siona-Secoya and the Advent of the Nation State. The Journal of Latin American and Caribbean Anthropology 1 (2): 55-60.

- 1998. Informe sobre las negociaciones entre los Secoyas de Ecuador y la Occidental Exploration and Production Company. (unpublished).

Vigh, Henrik, and David Brehm Sausdal. 2014. From Essence Back to Existence: Anthropology Beyond the Ontological Turn. Anthropological Theory 14 (1): $49-73$.

Viveiros de Castro, Eduardo. 1998. Cosmological Deixis and Amerindian Perspectivism. The Journal of the Royal Anthropological Institute 4 (3): $469-488$.

. 2012. Immanence and Fear: Stranger-events and subjects in Amazonía. HAU: Journal of Ethnographic Theory 2 (1): 27-43.

Wasserstrom, Robert. 2014. Surviving the Rubber Boom: Cofán and Siona Society in the Colombia-Ecuador Borderlands (1875-1955). Ethnohistory 61 (3): $525-548$.

Wasserstrom, Robert, and Douglas Southgate. 2013. Deforestation, Agrarian Reform and Oil Development in Ecuador, 1964-1994. Natural Resources 4: $31-44$. 
Weisskoff, Richard, and Edward Wolf. 1977. Linkages and Leakages: Industrial Tracking in an Enclave Economy. Economic Development and Cultural Change 25: 607-628.

Whitten, Norman E. 1978. Amazonian Ecuador: An Interface in Ecological, Social and Ideological Perspectives (Document 34). Copenhagen: IWGIA.

- 1981. Introduction. In Cultural Transformations and Ethnicity in Modern Ecuador, ed. Norman E. Whitten. Urbana: University of Illinois Press.

Wray, Natalia. 2000. Pueblos indigenas amazónicos y actividad petrolera en el Ecuador: conflictos, estrategias e impactos. Quito: IBIS and Oxfam América.

Open Access This chapter is licensed under the terms of the Creative Commons Attribution 4.0 International License (http://creativecommons.org/licenses/ by $/ 4.0 /$ ), which permits use, sharing, adaptation, distribution and reproduction in any medium or format, as long as you give appropriate credit to the original author(s) and the source, provide a link to the Creative Commons license and indicate if changes were made.

The images or other third party material in this chapter are included in the chapter's Creative Commons license, unless indicated otherwise in a credit line to the material. If material is not included in the chapter's Creative Commons license and your intended use is not permitted by statutory regulation or exceeds the permitted use, you will need to obtain permission directly from the copyright holder.

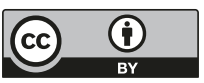




\title{
Translating Wealth in a Globalised Extractivist Economy: Contrabandistas and Accumulation by Diversion
}

\author{
Cecilie Vindal Ødegaard
}

The discourse of extractivism in Peru appears to offer a modernist vision of citizenship and progress accessible to all, and is presented by political leaders as key to economic growth and poverty reduction. Meanwhile, faced with recurrent conflicts and protests (de la Cadena 2010; Li 2015), Peruvian authorities have difficulties in legitimising their extractive politics. In Peru as elsewhere, fossil fuels have become an important site for sovereign contention (Mitchell 2011), and the transnationalised, capital-intensive extraction and distribution of fossil fuels are subject to degrees of regulation and control beyond any other commodity. Yet, as this chapter reveals, there are sites and moments of informalisation where the materialities of fuels and their attendant wealth are redirected and reconfigured.

Despite great interest in extractive conflict in South America in recent years, relatively few studies have focused on the tactics used by local groups and communities to mediate and redirect the forces of the state's extractive

\footnotetext{
C. Vindal Ødegaard $(\bowtie)$

University of Bergen, Bergen, Norway

e-mail: cecilie.odegaard@uib.no
}

(C) The Author(s) 2019

C. Vindal Ødegaard, J. J. Rivera Andía (eds.), Indigenous Life

Projects and Extractivism, Approaches to Social Inequality and

Difference, https://doi.org/10.1007/978-3-319-93435-8_5 
politics and the associated benefits. Most studies tend to focus primarily on groups and communities that unambiguously oppose the state's enforcement of extractive capitalism. In this chapter, I explore countermovements which challenge the extractivist state in ways that are more ambiguous and do not fit neat dichotomies of modern-indigenous, capitalist-traditional, accommodation-resistance. I discuss the smuggling of fuels from Bolivia to Peru, which became widespread after the Bolivian government's nationalisation of oil and gas in 2006 and the subsidisation of Bolivian energy prices. In so doing, I describe attempts to redirect the official distribution of fossil fuels and examine how contrabandistas seek to subsume fossil wealth to other modes of sociality as they redistribute profit by sharing and making investments in kin, colleagues, and earth-beings. ${ }^{1}$ In this and other ways, contrabandistas contribute towards the re-creation of local forms of relatedness in a manner that is closely entangled with extralocal, global commodities and aimed at the translation and integration of extralocal value. I argue that the contrabandistas' redirections of commodities from official circuits are part of life-making projects that partly differ from yet are partly complicit in hegemonic discourses on resource extraction and progress, and can be seen to entail a kind of translation from one form of value accumulation to another. In this manner, and drawing inspiration from Tsing's (2015) notion of translation between capitalist forms of accumulation and other economic forms, I seek to address the complexities of contemporary life in the context of extractivism in the Andes.

My observations and arguments are based on several periods of fieldwork in Peru since 1997, building mainly on work in 2007, 2011, and 2016. I worked on the Peruvian side of the border, with vendors and contrabandistas who carry merchandise between Peru and Bolivia, some of whom are based in Arequipa (where I conducted most of my fieldwork) and others who live in rural communities closer to the Bolivian border. Arequipa is an important regional distribution point for trade between the highland and the coast, as well as for merchandise brought into Peru from Bolivia and Chile. People come to Arequipa from as far away as Lima to buy contraband goods for further sale in the capital (see also Tassi et al. 2013). Central to my fieldwork, especially in 2011 and 2016, was following those of my interlocutors ${ }^{2}$ who work as contrabandistas connected to one of the outdoor markets in Arequipa, Mercado Nuevo. This market association has around 1500 members, many of whom are bilingual Spanish and Aymara, or Quechua speakers. The contrabandistas travel every week to collect merchandise and are important suppliers of goods to 
vendors and retailers at Mercado Nuevo; some have their own market pitches there. The contrabandistas are mostly migrants to Arequipa from communities in the Andean highlands and are generally but not exclusively women. While I cannot explore fully here the many reasons that women are in the majority in trade and contraband, a central dimension in this specific context is the notion that women manage money and economic matters while men manage politics (Harris 2000). There are long traditions in the Andes for women's involvement in barter and trade, so trading is not necessarily something first learned in the city. In many ways, the contrabandistas represent a kind of social banditry (Hobsbawm 1969) that redistributes wealth beyond the reach of state and extractive companies; their claims to earn a living hold for many a certain legitimacy, particularly in light of the state's extractivist policies of recent years. While contrabandistas rely on the flow of global commodities, I argue that they convert and translate these flows in and through practices that are embedded and implicated in local sociospatial relations. By convert and translate I mean to suggest that contrabandistas not only convert the flow of wealth to another circuit and form but also translate such flows from one system of relationships and meaning to another. My focus on the redirection and possible translation of fossil wealth is not intended to underplay, however, the issue of wealth accumulation and inequality in the extractive state. Rather, central to my argument is the view that smuggling has emerged from structures of inequality, both historically and in view of contemporary extractive politics in Peru, and that the contrabandistas exemplify some of the attempts made to mediate and redirect the forces of these politics. This, I argue, involves not only commodity flows but also the cultural, cosmological, and relational aspects, or logics, of mediation. $\mathrm{My}$ intention is not to romanticise a practice such as the smuggling of fuel, but, rather, to explore these practices from the perspective of the contrabandistas involved and, especially, to understand the relations through which such practices are realised.

The smuggling of fuels across the borders from Bolivia became particularly widespread after the Bolivian government's nationalisation of oil and gas in 2006 and the subsidisation of energy prices for the domestic market. Subsidisation lowered price levels in Bolivia below those of neighbouring countries, such as Peru, ${ }^{3}$ resulting in the illegal export of fuels from Bolivia (see also Montesinos 2011). In December 2010, the issue of illegal exports led the Bolivian government to remove subsidies, causing prices to almost double. People in Bolivia then protested, refusing to pay bus fares. After 
three days, the protests led to a reduction in prices — and the smuggling of fuels continued. In Peru, fuel smuggled from Bolivia is used primarily for ordinary consumption and in informal mining. ${ }^{4}$ Many of my interlocutors in Arequipa, especially the contrabandistas, justified the smuggling of fuel from Bolivia in the context of Peruvian energy politics. They cited the higher energy prices in Peru, arguing that Peruvian energy resources are also being exported. A typical response comes from one of my interlocutors: '[We get fuel in Bolivia], since it is cheaper [there]. We [Peruvians] also have gas, but we export it to other countries, at cheaper prices even, while we [ordinary citizens] have to pay a lot.'

Before going into the practices of smuggling, I discuss energy prices and price-setting mechanisms in Peru in recent years as relevant not only to popular protests in the country but also to the way in which contrabandistas legitimise their actions. Academic debates about extractivist conflicts tend to give less attention to the question of energy prices, in Peru and elsewhere, perhaps because concerns with domestic energy prices may have an undertone of populist political rhetoric and resource nationalism in many situations. In the context of this chapter, however, energy prices create an important backdrop for understanding both the global capitalist creation of fossil fuels as a commodity construct as well as the sense of unfairness that permeates contrabandistas' experiences of the state's extractive politics. Indeed, energy prices, exportation, and globalised price mechanisms represent a general concern especially among the urban poor-often Quechua- or Aymara-speaking migrants—with whom this chapter is concerned.

\section{Energy Politics, and Protests}

The idea that natural resource extraction will lead to economic growth and development for all is, as noted, prevalent in official discourse in Peru (see also Li 2015). Nowadays, it represents a model currently supported by state-corporate partnership and a liberal line with respect to foreign investment in the extractive sector. The extraction of oil in the country first started in 1971 with PetroPeru. ${ }^{5}$ During Alberto Fujimori's presidency in the 1990s, PetroPeru was privatised and economic policies increasingly liberalised, opening up for foreign investment in the energy sector. While the state still controls most downstream production, pipelines, and refineries, Argentina's Pluspetrol controls over half of the production of crude oil. Peru's major natural gas field, Lote 88, was opened in 2004 in the 
department of Cusco under the management of the state-corporate company Camisea. The Camisea fields are Peru's top energy source, producing 1.6 billion cubic feet of natural gas per day. Just under half of the production is sold in the domestic market at regulated prices and used mostly to generate electricity; some is allocated for industrial use in mining, for example, and a small percentage is sold to consumers for residential use and as motor fuel (Ødegaard 2015). When Camisea started producing in 2004, gas and electricity prices for Peruvian consumers were relatively low compared to neighbouring countries. Prices soon rose, however, as the royalties Peru earns from Camisea's exports fell sharply in competition with cheap gas from US shale producers.

During preparations for extracting gas in the Camisea area in the 1990s, the authorities failed at first to attract enough investment for the project. The political landscape was considered risky because of the 'dirty war' between the guerrilla movement Shining Path and military forces, and Peru's status as one of the region's poorest consumer bases. Foreign investments were further compromised by Fujimori's insistence on keeping natural gas for the domestic market, leading Shell to withdraw from the project. By the time Fujimori's government fell in 2000, Peru's economic leaders considered that they had to offer a favourable export option to attract investment by international companies. Pedro Pablo Kuczynski, who served as finance minister and later as prime minister in the Alejandro Toledo administration at the time, helped pass two pieces of legislation which allowed firms to export the gas from the smaller block 56, while fixing the price of gas from the larger block 88 for the domestic market. In 2007, the Spanish firm Repsol, which forms part of the Camisea consortium, obtained the rights to export gas from the Camisea fields. The same year Repsol signed a 15-year contract to export 70 per cent of the gas to Mexico's state electric utility, which pegs prices to the US benchmark, Henry Hub. ${ }^{6}$ Over the next five years, US shale producers drove the Henry Hub price down by more than half, taking Peru's royalties with it due to a progressive royalty scheme tying royalties to prices in the contracts signed by Toledo's government. Consequently, cheap gas in the United States contributed to lowering the price of Camisea gas committed to Mexico until 2023 , and the price ceiling on natural gas sold on the domestic market was lifted. Most political sides have later called for renegotiations of the Camisea contracts to extract higher royalties. In several protests, people have opposed the increased domestic prices of gas and electricity as well as the exportation of Camisea's natural gas (Ødegaard 2015). Protesters 
have also condemned previous governments for not connecting the gas fields with Peru's southern cities, including Cusco, the provincial capital of the state where the gas is extracted. In an attempt to amend the situation, then president Kuczynski (2016-2018) called for the extraction of more natural gas from the Camisea consortium via exploitation of new fields and expansion of the infrastructure needed to transport the gas from Cusco to other cities.

While protests against the extractive industries in Peru in recent years have been spurred primarily by social and environmental effects in the communities most immediately affected, the protests related to increased exportation and domestic energy prices are aspects of Peru's extractive politics most often criticised by the urban poor, including Quechua- and Aymara-speaking migrants. In Arequipa, energy prices, especially the price of gas, have been a continual concern for many. Several protests have been organised in the city; during my fieldwork of January 2011, hundreds of people marched to Plaza de Armas in Arequipa from the shantytowns protesting the rising price of gas. ${ }^{7}$ Similar protests followed in Cusco, Puno, and Tacna. ${ }^{8}$ In support of the demonstrators, the bus companies stopped running busses. During the protests, one of my interlocutors in the shantytown where I have lived during my fieldwork sessions said: 'This is a serious problem and therefore people protest; when the gas prices rise, the prices of everything else rise along with it. Transport, food, water: everything becomes more expensive, because everything moves with combustible [fuels].' Prices generally are interdependent with the price of gas, but fuel is also considered a source of mobility both literally (i.e., for transport) and socially (i.e., associated with a certain level of consumption and living conditions). Similar protests against energy prices have continued. In March 2016, for instance, there was one week of paralysing protest in the department of Ucayali over the increased cost of electricity, in which several peasant indigenous groups joined in, demanding additional reductions in the prices of water, cooking gas, and telephone services ${ }^{9}$ ( $\mathrm{La}$ República 2016).

While these and similar protests have focused specifically on energy prices, they reflect an attempt to contest the unequal distribution of wealth in a country considered rich with natural resources. They are a critique of the Peruvian government's accommodation of the interests of multinational companies, contesting the terms by which governments have developed extractive politics in the country. The people who protest represent a variety of different positions and perspectives in society: farmers and 
landowners, indigenous groups and urban consumers. While extractive conflicts in Peru are often envisioned as involving primarily rural indigenous groups, we should be careful not to rely on an understanding of such conflicts as an 'indigenous' issue, as this could serve to downplay the more wide-reaching issues raised by indigenous protesters. We should also be wary of potential dilemmas of an essentialised understanding of 'indigeneity' in extractive conflicts. Such dilemmas, as argued by Fabricant (2013) in the Bolivian context, are related, for example, to what an essentialised notion of indigeneity may mean for the large numbers of Quechua- and Aymara-speaking migrants who may not necessarily oppose resource extraction as such, and may even benefit from it, but may be contesting the general terms by which it is conducted.

Despite conflicts over the transnationalised price-setting mechanisms in Peru in recent years, there are a variety of ways in which inhabitants may try to 'localise' such global commodities and sometimes benefit directly from the extractive industries. In Peru, some inhabitants have anticipated business opportunities around extractive sites and along pipeline building routes. One such site is the new port constructed in Ica at the receiving end of a new pipeline from the Camisea fields. Already years before the pipeline was to be completed, migrants (often from peasant communities in the highlands) started arriving in the area around the port construction site and informally occupying land for housing and businesses in hopes that the new pipeline would bring economic opportunities. Another widespread practice in Peru is the initiation of informal mining projects, which often cause further damage to local communities and ecosystems through deforestation and pollution. The smuggling of fuel, which I discuss in more detail below, is another way to attempt to benefit from extractivist projects-one also taking place at the margins of the formal economy. In more ways than one, however, contrabandistas are the kinds of actors who are often left out of our analytical conversations, perhaps because it is not clear how we can understand their role in relation to globalised capitalism, nor how they contribute to an alternative 'politics of nature'. On the one hand, contrabandistas may appear as 'perfect neoliberal citizens', accommodating their own quest for a good life to growing demands of flow and consumption. On the other hand, they draw on a different mode of sociality (including the powerful earth-beings) in their ways of distributing commodities and understanding wealth. The contrabandistas may therefore appear to provide us with analytical plunder, bringing to mind questions about the nature of capitalism, and the (im)possibility of a space outside of capitalism's empire 
(e.g., Hardt and Negri 2000), or the potential for a coexistence with other forms of sociality and economic life (Tsing 2015).

Through perspectives that insist on the unity and homogeneity of the system, scholars often criticise capitalism for concentrating wealth through historically changing processes and technologies for extracting and accumulating value. This emphasis on the uniformity of capitalism and its hold on the world is also often considered essential for building a critical political position and for conceptualising possibilities to transcend capitalism, that is, through the envisioning of alternative forms of solidarity (Tsing 2015: 66). In seeking to understand the workings of capitalism, however, Tsing argues that we need to recognise the existence of economic diversity and explore the ways in which other economic forms can be found in the midst of capitalist worlds. Rather than discussing such forms primarily as alternatives to capitalism (see, e.g., Gibson-Graham 2006), Tsing suggests we pay attention to the elements and activities, both human and nonhuman, which are integrated into global supply chains and accommodate capitalist accumulation, despite existing outside official systems of control. Tsing (2015: 63) calls such forms the 'pericapitalist mode', referring to activities accommodated to a capitalist value system through different forms of conversion and translation. For instance, the pericapitalist mode may refer to the process through which lead firms can amass capital without controlling the conditions under which commodities are produced (also termed salvage accumulation). Pericapitalist economic forms, Tsing argues, can even be important sites for rethinking the authority of capitalism in our lives: 'To understand capitalism (and not just its alternatives), then, we can't stay inside the logics of capitalists; we need an ethnographic eye to see the economic diversity through which accumulation is possible' (ibid.: 66). This chapter focuses on a somewhat different phenomenon, by exploring commodity flows and forms of wealth distribution that take place outside the reach of both the state and lead firms and raising the following questions: What characterises the activities of contrabandistas visà-vis global commodity chains? What forms of conversion and translation are the contrabandistas involved in? My focus on translation draws upon, but also elaborates further upon, Tsing's notion of translation through the pericapitalist mode. More generally, it draws inspiration from a wellestablished body of scholarship emerging especially from feminist anthropology, having shown that class formation is cultural formation, and having pioneered the study of transactions across heterogeneous economic landscapes (see, e.g., Yanagisako 2002; Harris 2000; Ong 2006). I draw 
on the term translation precisely to capture the way that acts of conversion and translation in global capitalism may take place across varied social, cultural, and political spaces. According to Tsing, translations across sites of difference are capitalism in that they enable investors to accumulate wealth. Translation, in this sense, is the drawing of one world- and lifemaking project into another, which is often, although not always, facilitated by the capitalist system of commensuration (Tsing 2015: 62). To work with a notion of translation in this wider sense is interesting because, while it may draw attention to language, it can also refer to other forms of partial accommodations, or partial connections (Strathern 2004).

\section{The Smuggling of Fuels}

Those who bring in contraband generally self-identify as contrabandistasproudly so. They are viewed as important suppliers of merchandise, constantly travelling long distances to bring goods to market vendors. As I have discussed elsewhere $(2008,2016)$, contrabandistas often criticise official interferences as immoral and illegitimate, questioning the right of the officials to interfere in people's efforts to make a living. The legal assessor of the Chamber of Commerce and Industry in Arequipa estimated that almost 90 per cent of the inhabitants in border areas are involved in contrabando and provide consumer goods to the entire country: 'It is difficult to do anything, because people get angry, and will ask for an alternative-something which does not exist.' ${ }^{10}$ As mentioned, contrabandistas may be considered as practitioners of a kind of social banditry (Hobsbawm 1969), as their claims for the right to earn a living hold a certain legitimacy. Their claims are informed by historical structural inequalities and by the recognition that there are no other jobs to get anyway, an assertion typical of many contrabandistas. From an official perspective though, fuels are not 'just another commodity': Fuels are capital-intensive rather than labour-intensive, demanding advanced technology and infrastructure. The extraction and distribution of oil and natural gas are highly institutionalised, corresponding with the high demand in the global market for these commodities. In this regard, the illegal export of fuels not only represents economic loss ${ }^{11}$ for countries such as Bolivia where energy prices are subsidised, but also raises questions of national borders and state sovereignty. Fuel smuggling (as well as the facilitating bribes) in effect contests state-corporate interests and investment; it entails denials both of state legitimacy in the control of commodity flows and of territorial boundaries themselves, and further exposes 
the extractivist state's problem of legitimatising its energy politics. Through smuggling, fuels are made into petty commodities, de-institutionalised and informalised, amounting to a challenge to sovereign investment in fuel extraction and distribution. As I have examined elsewhere (2016), measures to reduce smuggling have been introduced on both sides of the borderparticularly in Bolivia where the government has targeted border control measures especially with regards to fuel smuggling.

People from both the Peruvian and Bolivian side of the border are involved in the trafficking of fuel (petrol, diesel). They often buy fuel at petrol stations in Bolivia with the purpose of selling it in Peru. Some contrabandistas, especially the women, transport fuel across the border by foot or bicycle trolley, while others hide it on the roofs of buses amidst luggage. The drivers involved in fuel smuggling are generally men who combine their professional work as drivers (bus, truck or car) with contraband activities, often delivering the smuggled fuel to specific addresses (e.g., petrol stations or shops) in Peru for further sale. Some drivers practice acopio de combustible, gathering fuels little by little before transporting them across the border. In the smaller villages close to the border, there are casa de acopio, houses where people stockpile fuel before taking it across the border by night. Some cars have a double tank, or falso piso. Large-scale fuel smuggling also takes place by night in trucks travelling in rows referred to as culebra or serpiente (snake), sometimes bringing goods from the border areas all the way to Cuzco. These trucks are said to leave behind sacks of food or other goods in local communities along the way in return for help in realising the smuggling. Several interlocutors said that the trucks also pass without interference by leaving bags of money at local police stations.

The towns of Desaguadero and Puno are important locations for the transport and sale of illegally imported fuel in Peru. In both towns, the fuel has at times been sold quite openly on the streets, while in cities like Arequipa sales have been more covert. Desaguadero is located at the border between Peru and Bolivia; here one officially crosses the border at a bridge where people pass either on foot or by bicycle trolley. Those who have larger loads pass by boat a distance away from the bridge. In the area around the bridge, there are people who, for around two soles, will transport people's goods across the border. Referred to in the media as pulgas or hormigas (lice or ants), these couriers may pass the border many times to bring a customer's merchandise across. People come to Desaguadero 
from across Southern Peru to buy contraband goods, including fuel. To pass the border with their goods, people commonly pay coima (a bribe) to the custom officials (generally 2-3 soles to enter Bolivia, and 10-20 soles on the way back). For a time from 2009 onwards, one of my interlocutors, Olinda, earned a living by bringing fuel from Bolivia, often travelling by bus and placing her goods on the roof hidden underneath other packages. She brought about 50 gallons at a time to sell to petrol stations in Puno where the smuggled fuel was usually mixed with ordinary products. Olinda made her initial investment with the help of her husband, who is a driver and could facilitate free transport. To live closer to the border and have a place for her goods, she rented a room from a relative in Yungoyo, ${ }^{12}$ a peasant community close to the border. Olinda is originally from Arapa, and the couple's three children have stayed behind in the village with their elderly grandmother, living under extremely poor conditions while their parents have been working. One day, just before I reached Arequipa in 2011 , Olinda was caught with fuels worth 10,000 soles. All of her goods were confiscated, and she had to pay 3000 soles to the custom officials (in bribes, not in fines) before the bus could pass. As we talked one day about the incident while sitting at her sister's market pitch at Mercado Nuevo, Olinda stressed how much she had suffered and cried after she was caught and lost her capital. She soon reestablished her business through the help of her kin, but decided not to include fuels. Although she had been rather successful and her earnings had been converted into the construction of a modern house (of brick and cement with glass windows) back in Arapa as well as education for her children at a private school in Arequipa, she now started to bring olives and clothes instead of fuels. 'You win and you lose, but you just have to continue', Olinda said. This is typical for contrabandistas' narrations about the risks that their businesses involve, stressing how they cry and suffer when their goods are confiscated-but also how they start up anew after a short time, still within the contraband trade, although sometimes downsizing quantities, or switching to another commodity. Olinda's narration indicates how contrabandistas spend their earnings for the benefit of their family and relations. While these earnings originate in illegal economic activities that challenge state-corporate interests and investments, the profits are sometimes spent in accordance with an urban middle-class life standard ideal (such as, in the case of Olinda, on a modern house and education), in addition to gifts, offerings and other 'relational' expenditure, as I illustrate below. 


\section{Prosperous Socialities}

Smuggling takes place in areas considered as tierras de nadie (no man's land), referring to places characterised by a history of marginalisation, a strong sense of local autonomy, and the ambiguous presence of state actors. These are areas where trade is already institutionalised in the absence of state control. The social and spatial embeddedness of trade is central to the practices of smuggling, which are based in networks of cooperation through household and kinship relationships that span from rural to urban areas. These relationships along trading routes may provide, for example, information and supply or storage of goods (see also Smith 1989; Babb 2001; Seligmann 2001; McNeish 2001; Ødegaard 2008, 2016). Success in the contraband business depends on relationships of trust, cooperation, and mutual exchange. Contrabandistas and vendors cultivate social relations assiduously through the sharing and giving of food and gifts, by establishing familial connections through godparenthood, and by maintaining often relatively stable relationships with customers and suppliers. Social relations thus enable the distribution of goods, including fuel, beyond authorised infrastructures and institutions.

More often than not, public functionaries are willing to receive bribes in exchange for their non-interference and to let people pass with their goods. In this way, the relational character of trade seems to constitute a means by which state officials at different levels can make money from the extralegal activities of contrabandistas. These exchanges are called bribes (coima) and not gifts, although contrabandistas often draw a parallel between coima and gift and view it as lack of respect when public functionaries refuse to accept a coima. As I explore below, similar dynamics of mediation and exchange take place in contrabandista relations with earth-beings. Powerful surroundings and apus (mountain lords), like the public functionaries, must be appeased through gifts or offerings to ensure, among other things, the circulation of merchandise. Comparable strategies - gifts, offerings, bribesare thus called for in dealings with representatives of the state as with the earth-beings to ensure control of commodity flows. Krøijer (this volume) discusses a different yet related situation among the Secoya in Peru. According to oil's essential leakiness, the Secoya establish an analogous relationship between oil, blood, and other (unintended) flows to deal with the oil present in their territory: a substance that if not contained and handled correctly might disturb the healthy flow between body and territory and powerful 'others'. In the case of the contrabandistas, they work primarily to 
redirect the flow of fossil fuels and the associated wealth, and to do so require mediation of and by other powerful substances and entities.

Interregional trade and barter have been essential to people in the Andes for centuries (Murra 1980; Platt 1982; Larson and Harris 1995). In the Southern Andes, contemporary cross-border trade follows the same routes used during the colonial period along which mule drivers transported goods between highland towns, such as La Paz, Puno, and Arequipa as well as towns along the Pacific coast, to Chile. While building on a long-standing history of barter and trade, interregional trade increased significantly during the 1980s-90s in both rural and urban areas (Smith 1989; Babb 2001; Seligmann 2001; Montesinos 2007, 2011; Tassi et al. 2013). In reaction to labour surplus and rising unemployment caused by structural adjustment programmes imposed by the IMF-implying privatisation and a reduction of the public sector-people increasingly turned to cross-border trade and market work, particularly during the economic downturn of the 1980s. Then as now, this work often takes place at the margins of the formal economy and builds upon social structures that have facilitated access to the market on the vendors' own terms (see Larson and Harris 1995; Arnold and Spedding 2009; Tassi et al. 2013). Against this backdrop, it could be tempting to interpret the practices of contrabandistas as a response to socio-economic processes and inequality, or as a form of non-hegemonic globalisation 'from below' (see Lins Ribeiro 2009) similar to the development of informal economies taking place worldwide. Such a focus would, however, emphasise mainly the economic nature of the contrabandistas' activities and could lead us to reduce their practices to a question of economic positioning. It could lead us to ignore important historical continuities of relational economics in the Andes and undermine ethnographic specificities by downplaying difference and ways of 'conceptualising otherwise' among contrabandistas, that is, conceptualising that departs from the Euro-American. Despite their strong Aymara and Quechua origins, the contrabandistas have usually been addressed by ethnographies more interested in economic 'informality' in South America (Goldstein 2016) than in Amerindian worldviews. In contrast, this chapter considers that the contrabandistas' redirection of commodity flows from official distribution entails a subsumption of wealth to modes of sociality and relationships that differ from the dominant forms. In an attempt to rethink a critical anthropological politics informed by the so-called ontological turn, Hage (2012) argues for the need to explore precisely the ontological underpinnings of relations of inequality. According to Hage, a social relation can always be understood 
in more than one way; that is, a social relation is always more than a 'relation of power', a 'relation of domination', or a 'relation of exploitation' (2012: 306). While we can recognise a social relation as a relation of power and dominance that reproduces a certain order of things, drawing on critical sociology, we should recognise the potential also for radical alterity-that there may be 'an outside of a system of intelligibility, of governmentality, of domestication, of instrumental reason' (ibid.: 306). This, I find, is a relevant point for the case of the contrabandistas; while their relations are certainly ones of historically conditioned inequality and marginalisation (i.e., relatively poor people with an indigenous background), we need to reveal also the relations of difference and translation that are likewise at stake.

By redirecting global commodities into informal circuits of exchange and distribution, contrabandistas profit, and, simultaneously, subsume profit to particular modes of sociality that rely on mutual exchange and gift giving (see also Gandolfo 2013). The wealth of an extractivist economy is, in this manner, translated to another set of distributive relations, where wealth is circulated and distributed in different ways and has the potential to create other sets of relations (although the accumulation of wealth is not avoided altogether, as is discussed below). Rather than representing a mode on which official commodity chains of capitalism depend, however, such as the pericapitalist mode outlined by Tsing, the informal circuits of contrabando divert and multiply the forms that extractive wealth may take. Instead of contributing to capitalist accumulation as discussed by Tsing then (and pinpointed by Harvey's (2007) term 'accumulation by dispossession'), this unofficial mode of translation can be termed accumulation by diversion, representing a mode by which wealth is partly subsumed and converted to a different form and enter different relationships. This conversion or translation is not only economic in nature; global commodities and flows are integrated into other relations and other sets of symbolic meaning. The translation and redistribution therefore entails a semiotic multiplication too, as wealth is translated to another set of relationships and meaning, escaping (partly) capitalism's system of commensuration and elite accumulation. We could view this as a relation of partial connection. According to Strathern (2004), the relation between dissimilar domains can only ever be as partial connections, by which a relationship composes an aggregate that is 'neither singular nor plural, neither one nor many, a circuit of connections rather than joint parts' (2004: 54). As I illustrate in the following, a central dimension to contrabandistas' acts of conversion and translation are their relations to earth-beings as powerful sources of wealth as well as danger. 


\section{Mobility, Wealth, and Translations OF THE EXTRALOCAL}

Many contrabandistas perform offerings to both powerful earth-beings and saints as a way of maintaining good relations with the sources of wellbeing and wealth and to improve success in business. The making of offerings is among the practices that characterise a relationship with the powerful Andean landscape (see also Allen 1988; Lund Skar 1994; Harris 1995; Canessa 2000; de la Cadena 2010; Ødegaard 2008, 2011) and reflects a particular cosmology of place where earth-beings are considered to have a powerful influence over the lives of humans with the potential for bringing prosperity as well as causing harm. Offerings consist of alcohol, food, llama fat, herbs, or coca and are made to pachamama (earth) and the apus (mountains), or to virgins or saints considered to be particularly prosperous and powerful. Large-scale contrabandistas and vendors are also expected to serve as sponsors for offerings, festivals, and parties, illustrating the significance of a relational understanding of wealth among contrabandistas as being dependent on reciprocity, circulation, and exchange between humans and earth beings (see also Harris 2000). Earth-beings represent an extrahuman prototype of 'other', whose power may be actualised in the form of health, income, and wealth, but also in the form of illness, accidents, and death. Sustained by the offerings, earth-beings depend on the same vital substances as humans do (alcohol, meat, fat, coca) and have similar needs and feelings. Along similar lines, although from a different perspective, Stensrud (this volume) illustrates how earth-beings in the Peruvian context are not necessarily deliberately (re)invented as part of an indigenous strategy to stop extractivism; rather, they are part of relationships continuously nurtured within on-going life projects (see Blaser 2004).

Deprived of offerings, the earth-beings may also attack human beings and cause illness and even death. The health and boundaries of the human body must therefore be maintained by making gifts and offerings to the earth-beings. Travellers, such as the contrabandistas, who voyage great distances are especially vulnerable. While contrabandistas tend to celebrate flow and mobility, which I discuss below, they are vulnerable not only to interfering state functionaries at border check points, but also to potentially malevolent earth-beings. Travellers need to protect themselves against powerful surroundings, by, for instance, making offerings or bringing stones, soil, or food from the place left behind. Movement through powerful surroundings, which are located and manifested in 
different local and regional landscapes, may disturb the flow of material exchanges and communication between a person and the surroundings, putting the traveller in danger (see also Allen 1988; Lund Skar 1994; $\varnothing$ degaard 2011). Danger can arise because the soil of a new place may not yet know you, a situation that can threaten one's health and general wellbeing. The notion that a place can know refers in this case to a way of knowing (someone or something) through the exchange of material substance: that is, you know someone based on what they give you. A traveller can achieve this knowing by bringing soil or a stone in a bag or pocket from their starting point or by making an offering. By bringing substances or objects from the place left behind to a new environment, the powers from the starting locale may mediate with the powers at a new place of arrival, enabling the traveller to reestablish a relationship with a powerful landscape. Although thus potentially dangerous, movement and circulation represent important cultural values in the Andes, as part and parcel of the reciprocal relationship between humans and earth-beings. In this regard, the general appreciation in this context of the often hard-working contrabandistas may illustrate Harris' (1995: 309) point that those who engage in trade in the Andes provide an important social service by bringing goods and making money 'give birth', hence ensuring material flows.

Material exchanges between humans and earth-beings rely on a notion of wealth that differs from the predominant, modernist vision in public discourse of progress and development, as, for instance, furthered by resource extraction and the perception of 'nature as object'. Commodification and monetisation of 'natural resources' enable a disconnection from place and a separation of subject and object-making nature a passive object from which humans can extract resources. The offerings made by contrabandistas entail ontological dynamics that provide a different understanding. Despite this and other ways of contravening the dominant form of capitalist accumulation and extraction, the political/symbolic economy of contrabandistas is simultaneously closely entangled with the extralocal (e.g., through the informalisation of global commodities). The social, economic, and ritual ways of contrabandistas can be seen as a practice aimed at the integration and translation of ambivalent extralocal value (see Orta 2004), and form part of an emphasis on harnessing value to create kinship; or familiarising predation in Fausto's terms (2007). Their practices turn on translating, incorporating and harnessing extralocal values to local ends, such as the use of global commodities for informal trade, 
sharing, and consumption. These practices are part of life-making projects that rely on forms of redirection or 'leakage' from official commodity circuits, and are in many ways complicit with capitalist extraction as the practitioners benefit, albeit to a limited extent, from the wealth produced. The perspective and mode of sociality of the contrabandistas differs from the dominant capitalist paradigm though, as their practices aim to recreate local forms of relatedness (see Penfield, this volume, for a similar argument). The relations that result can be seen as an aggregate of partial connections (Strathern 2004), creating not a single entity but an entity that is more than one yet less than two.

Contrabandistas are nevertheless receptive to dominant terms like those of progress and development and also speak in such terms-that is, by applying a notion of progress to their own lives as well as those of others. As Evangelina, one of my interlocutors, said about one of her more successful contrabandista colleagues, who has accumulated more wealth than many of her colleagues: 'She is really progresada. ${ }^{13}$ She carries dollars under her skirt (pollera), she has bought a big house in the city, and has even invested in a truck.' This allusion to wealth being 'carried under her skirts' is related to the notion that women in this part of the Andes are considered more likely than men at saving earnings and taking care of wealth and issues of reproduction (see Harris 2000). Interestingly, among contrabandistas, the truck occupies a central position in symbolic and economic elaborations of an idea about movement and circulation. For instance, at festivals organised by vendors and contrabandistas at Mercado Nuevo, miniature trucks figure in some dances, especially one in which women swirl colourful ropes with miniature ${ }^{14}$ trucks fastened to the ends. These women are usually dressed in polleras from Puno, generally of the most recent, colourful fashion and expressive of the successful and economically powerful Aymara entrepreneur. Vendors at the market also sell miniature trucks for offerings made in the hope of acquiring a real truck or other forms of wealth. The truck symbolises the work of contrabandistas and the flow and circulation of goods and money that they ensure. The truck also symbolises wealth and progress. As in the case of Evangelina's colleague, contrabandistas who succeed in their businesses often choose to invest in a truck for the purpose of continuing the practice that allowed them to acquire the truck-transporting contraband goods. 


\section{Conclusions}

By redirecting the official distribution of fossil fuels, contrabandistas subsume fossil wealth to other modes of sociality, for instance, by sharing and investing in colleagues, kin, and earth-beings. In this chapter, I have argued that contrabandistas can be viewed as translators from one form of value accumulation to another, not to the state or to the benefit of dominant firms as in the pericapitalist mode (Tsing 2015) but to forms of sociality and locality that to a great extent evade authorised institutions and infrastructures of distribution. While contrabandistas facilitate the circulation of global commodities, theirs is a different kind of life project (Blaser 2004) with a perspective and mode of sociality where flow is aimed at recreating local forms of relatedness.

Instead of contributing to capitalist accumulation in a conventional sense, the contrabandistas practice accumulation by diversion by which wealth is subsumed and converted to take different forms and enter different relationships. The translation and redistribution entail a semiotic multiplication as well, as wealth is translated to another system of meaning and (partly) escapes the capitalist system of commensuration. Their practices implicate and create social relations, including relations to the powerful earth-beings, and involve a relational understanding of wealth as dependent on reciprocity, circulation, and exchange. These practices rely on a notion of wealth that departs from the dominant, modernist vision expressed in public discourse of progress and development, as, for example, facilitated through resource extraction and the perception of 'nature as object'. The contrabandistas' redirections of commodities from official circuits are part of life-making projects that partly differ from and are partly complicit with hegemonic discourses on resource extraction and progress in that they are closely entangled with the translation and conversion of extralocal value. As a result, the practices of contrabandistas uncover the porous entanglements, or the partial connections, of locally embedded practices and the extractive politics of the state. Extractive capitalism in this context thus seems to coexist in partial connection with a radically different alternative.

While most studies of extractive conflicts in South America focus on groups who unambiguously resist the state's enforcement of extractive politics, I have revealed some of the tactics and concepts used to mediate these forces and the associated wealth (see also Krøijer, this volume, and Penfield, this volume, for related arguments). My focus on this redirection and possible translation of fossil wealth has not been intended to underplay, however, the issue of wealth accumulation and inequality in the 
extractive state. On the contrary, smuggling must be seen to emerge from relations of inequality, both historically and in view of contemporary extractive politics in Peru. Contrabandistas legitimate their practices with reference to conditions of inequality as well as contemporary price-setting mechanisms, and smuggling can be considered a way to mediate the forces of the state's extractive politics. Understanding these practices requires attention not only to commodity flows but also to the relational, cultural, and cosmological aspects, or logics, of mediation.

Acknowledgements My warmest thanks to people and friends in Peru who were so kind and helpful to let me follow them in their daily lives and who shared with me their experiences and points of view. Many thanks also to Juan Javier Rivera Andía for his constructive comments and to Katharine Wheeler and Isabelle Hugøy for their help with language editing; your assistance, advice and support is highly valued! I would also like to thank Casey High for his valuable suggestions based on an earlier version of this chapter, and to John McNeish and the project Contested Powers, for providing funding from the Research Council of Norway for some of my fieldwork. In addition, many thanks to Magaly Cardich for her research assistance during one of my fieldworks.

\section{Notes}

1. I use the term earth-entities to refer to nonhuman beings of the landscape, such as pachamama (earth) and apus (mountains) (see de la Cadena 2010, and Stensrud, this volume).

2. Names of interlocutors and places have been changed for purposes of anonymity.

3. Bolivia's prices were about one-third of prices in Peru.

4. Along Cuenca Suche, the river that goes through Desaguadero, there are a range of unauthorised mining businesses.

5. Peru Oil Exploration Set, 15 October 1971, https://www.nytimes. com/1971/10/15/archives/peru-oil-exploration-set.html, accessed 23 February 2017.

6. Henry Hub is a distribution hub on the natural gas pipeline system in Louisiana owned by Sabine Pipe Line LLC. The importance of this hub is reflected in the use of its name for the pricing point for natural gas future contracts that are traded on the New York Mercantile Exchange. In finance, such future contracts are legal agreements to buy or sell something at a specified time in the future at a predetermined price.

7. From 14 to 15 soles per gallon of gas, while other types of gas ( 95 per cent) rose to 20 soles. 
8. Also in July 2010, there were protests in Cuzco, Puno, Tacna, and Arequipa against the exportation of gas from Camisea.

9. Levantan provisionalmente huelga en Ucayali tras 11 días de manifestaciones, 19 March 2016. http://larepublica.pe/politica/749727-levantanprovisionalmente-huelga-en-ucayali-tras-11-dias-de-manifestaciones, accessed 23 February 2017.

10. This is from an interview which took place in Arequipa in 2011.

11. In 2011 , illegal export of fuels represented a loss of approximately US $\$ 450$ million for Bolivia (La Razón, La Paz, 27 January 2011).

12. I have changed the original names of these villages.

13. This is a neologism meaning that 'she has progressed'.

14. This use of miniatures is part of a wider practice in the Southern Andes referred to as las alasitas.

\section{REFERENCES}

Allen, Catherine. 1988. The Hold Life Has. Coca and Cultural Identity in an Andean Community. Washington/London: Smithsonian Institution Press.

Arnold, Denise, and Alison Spedding. 2009. La region altiplano como espacio económico. In Altiplano, ed. Denise Arnold. La Paz: UNIR.

Babb, Florence. 2001. Market/Places as Gendered Spaces: Market/Women's Studies over Two Decades. In Women Merchants in Cross-Cultural Perspective: Mediating Identities, Marketing Wares, ed. L. Seligman. Redwood City: Stanford University Press.

Blaser, Mario. 2004. Life Projects: Indigenous People's Agency and Development. In In the Way of Development. Indigenous Peoples, Life Projects and Globalization, ed. Mario Blaser, Harvey A. Feit, and Glenn McRae. London: Zed Books.

Canessa, Andrew. 2000. Fear and Loathing on the Kharisiri Trail: Alterity and Identity in the Andes. Journal of the Royal Anthropological Institute 6: 705-720.

de la Cadena, Marisol. 2010. Indigenous Cosmopolitics in the Andes: Conceptual Reflections Beyond "Politics". Cultural Anthropology 25 (2): 334-370.

Fabricant, Nicole. 2013. Good Living for Whom? Bolivia's Climate Justice Movement and the Limitations of Indigenous Cosmovisions. Latin American and Caribbean Ethnic Studies, Special Issue: The Politics of Indigeneity in Bolivia 8 (2): 159-178.

Fausto, Carlos. 2007. Feasting on People: Cannibalism and Commensality in Amazonia. Current Anthropology 28 (4): 497-530.

Gandolfo, Daniella. 2013. Formless: A Day at Lima's Office of Formalization. Cultural Anthropology 28 (2): 278-298.

Gibson-Graham, J.K. 2006. A Postcapitalist Politics. Minneapolis: University of Minnesota Press. 
Goldstein, Daniel M. 2016. Owners of the Sidewalk: Security and Survival in the Informal City. Durham/London: Duke University Press.

Hage, Ghassan. 2012. Critical Anthropological Thought and the Radical Political Imaginary Today. Critique of Anthropology 32 (3): 285-308.

Hardt, Michael, and Antonio Negri. 2000. Empire. Cambridge, MA: Harvard University Press.

Harris, Olivia. 1995. The Sources and Meanings of Money: Beyond the Market Paradigm in an Ayllu of Northern Potosi. In Ethnicity, Markets and Migration in the Andes. At the Crossroads of History and Anthropology, ed. Brooke Larson and Olivia Harris. Durham: Duke University Press.

- 2000. To Make the Earth Bear Fruit: Ethnographic Essays on Fertility, Work and Gender in Highland Bolivia. London: Institute of Latin American Studies.

Harvey, David. 2007. Neoliberalism as Creative Destruction. Annals of the American Academy of Political and Social Science 610 (1): 21-44.

Hobsbawm, Eric. 1969. Bandits. London: Delacorte Press.

Larson, Brooke, and Olivia Harris, eds. 1995. Ethnicity, Markets and Migration in the Andes: At the Crossroads of History and Anthropology. Durham: Duke University Press.

Li, Fabiana. 2015. Unearthing Conflict: Corporate Mining, Activism, and Expertise in Peru. Durham: Duke University Press.

Lins Ribeiro, Gustavo. 2009. Non-hegemonic Globalizations. Alternative Transnational Processes and Agents. Anthropological Theory 9 (3): 1-33.

Lund Skar, Sarah. 1994. Worlds Together, Lives Apart: Quechua Colonization in Jungle and City. Oslo: Scandinavian University Press.

McNeish, John. 2001. Pueblo Chico, Infierno Grande. Globalisation and the Politics of Participation in Highland Bolivia. PhD dissertation, Goldsmiths College, University of London.

Mitchell, Timothy. 2011. Carbon Democracy. Political Power in the Age of Oil. London/Brooklyn: Verso.

Montesinos, Jorge. 2007. Across the Highland: Construction of Aymara Identity at the Chile-Bolivia Border: National Representations, Ethnic Categories, and Transborder Exchanges. San Diego: University of California.

- 2011. Comerciantes Aymaras y circuitos transfronterizos en Bolivia y Chile. Paper presented at ERIP/CILAS/LACES conference, San Diego.

Murra, John Victor. 1980. The Economic Organization of the Inca State. Greenwich: Jai Press.

Ødegaard, Cecilie Vindal. 2008. Informal Trade, Contrabando and Prosperous Socialities in Arequipa, Peru. Ethnos. Journal of Social Anthropology 73 (2): 241-267.

. 2011. Sources of Danger and Prosperity: Mobility and Powerful Surroundings in the Andes. Journal of the Royal Anthropological Institute (formerly $M A N)$ 17: 339-355. 
2015. Everything Moves with Fuel. Energy Politics and the Smuggling of Energy Resources. In Contested Powers: The Politics of Energy and Development in Latin America, ed. John McNeish, Axel Borchrevink, and Owen Logan. London: Zed Books.

- 2016. Border Multiplicities. At the Crossroads between Regulation and Improvisation in the Andes. Journal of Borderlands Studies 31 (1): 23-38.

Ong, Aihwa. 2006. Neoliberalism as Exception: Mutations in Citizenship and Sovereignty. Durham: Duke University Press.

Orta, Andrew. 2004. Catechizing Culture. Missionaries, Aymara and the "New Evangelization”. New York/Chichester: Columbia University Press.

Platt, Tristan. 1982. The Role of the Andean Ayllu in the Reproduction of the Petty Commodity Regime in Northern Potosií (Bolivia). In Ecology and Exchange in the Andes, ed. David Lehmann. Cambridge: Cambridge University Press.

Seligmann, Linda J. 2001. Peruvian Street Lives: Culture, Power, and Economy Among Market Women of Cuzco. Urbana: University of Illinois Press.

Smith, Gavin. 1989. Livelihood and Resistance: Peasants and the Politics of Land in Peru. Berkeley: University of California Press.

Strathern, Marilyn. 2004. Partial Connections. New York: AltaMira.

Tassi, Nico, Carmen Medeiros, Antonio Rodriguez-Carmona, and Giovanna Ferrufino. 2013. "Hacer plata sin plata". El desborde de los comerciantes populares en Bolivia. La Paz: Programa de Investigación Estratégica en Bolivia.

Tsing, Anna Lowenhaupt. 2015. The Mushroom at the End of the World. Princeton: Princeton University Press.

Yanagisako, Sylvia Junko. 2002. Producing Culture and Capital. Family Firms in Italy. Princeton: Princeton University Press.

Open Access This chapter is licensed under the terms of the Creative Commons Attribution 4.0 International License (http://creativecommons.org/licenses/ by $/ 4.0 /)$, which permits use, sharing, adaptation, distribution and reproduction in any medium or format, as long as you give appropriate credit to the original author(s) and the source, provide a link to the Creative Commons license and indicate if changes were made.

The images or other third party material in this chapter are included in the chapter's Creative Commons license, unless indicated otherwise in a credit line to the material. If material is not included in the chapter's Creative Commons license and your intended use is not permitted by statutory regulation or exceeds the permitted use, you will need to obtain permission directly from the copyright holder.

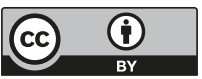


Extractivism, Land, Ownerships 


\title{
Water as Resource and Being: Water Extractivism and Life Projects in Peru
}

\author{
Astrid B. Stensrud
}

\section{INTRODUCTION}

'In Majes we are at war against a hostile and tough topography, against a nature that we must change, we are at war with the underdevelopment and this makes us impatient.' These were the words of engineer Oscar Valdivia Ávalos, the CEO of the Majes Irrigation Project (MIP), ${ }^{1}$ in the speech he held after signing a contract for completing the project in 1977 (Zamalloa 2013: 36). MIP consists of the Condoroma dam at 4158 metres of altitude in the headwaters of the Colca-Majes watershed in the southern Peruvian Andes, in addition to the Majes Canal, a planned hydropower plant, and an extensive network of irrigation infrastructure that will cover more than 50,000 hectares in the desert flatlands of Majes. As of 2017, 15,800 hectares have been irrigated, while the upcoming second phase-in which the remaining 38,500 hectares will be irrigated-has been delayed due to various reasons like shifting governments, economic crisis, and, after 2010 , protests against the new dam in the highlands. MIP is part of the Peruvian government's vision of development: to master nature in order to exploit it and to use water and land
A. B. Stensrud $(\bowtie)$
University of Oslo, Oslo, Norway
e-mail: a.b.stensrud@sai.uio.no

(C) The Author(s) 2019

C. Vindal Ødegaard, J. J. Rivera Andía (eds.), Indigenous Life

Projects and Extractivism, Approaches to Social Inequality and

Difference, https://doi.org/10.1007/978-3-319-93435-8_6 
to create as much economic value as possible. This is what I call water extractivism in this chapter: the practice to singularise and standardise water into the category of 'resource' in order to master it and extract as much economic value from it as possible. The war of the Peruvian state was - and still is - not only against topography and nature, it is also a war against the other-than-human beings who inhabit the steep mountain landscape that seem hostile to engineers and politicians, yet is home to thousands of peasant farmers and their alpacas and other animals. The mountains can be hostile, indeed; by local indigenous farmers, they are known to be sentient, capricious, and unpredictable and to 'eat' those who disrespect them. This world of living earth-beings is what the CEO called 'underdevelopment' and a 'nature that we must change'. The dominant view held by most of the political and economic elite based mainly in Lima has, since the start of the Peruvian Republic, been that the world- and life-making projects of the Quechua-speaking peasant farmers in the highlands are 'backward' and hinder modernity and development. Indigenous life projects are excluded from the design of megaprojects of modernity, and they are considered to be irrelevant and dispensable in the war against underdevelopment and in the pursuit of progress.

People in poor rural areas in the Andes tend to welcome megaprojects because they hope for employment and benefits such as improvements of roads, construction of schools, and other material gains, yet they often perceive development projects to be intrusive and as causing trouble. It is important to note, however, that hydraulic infrastructure is not unknown to farmers in Colca Valley, where farmers use a complex network of canals and pipes to bring water from the mountain springs to their ponds and cultivated fields. What makes MIP different is the large scale of the canal and the unequal distribution of benefits and power. During the planning and construction of MIP, the possible consequences for the farmers and their life-worlds in Colca Valley were not taken into consideration. Yet, the impact was huge; MIP transformed the ecological and social composition of the watershed and opened spaces for economic and political demands and struggles. Those who have gained access to water from the Majes Canal have accepted paying a higher irrigation tariff for the water from the Majes Canal than they pay for water coming from natural springs, and in return, many have extended their areas of cultivation.

Almost 40 years after the speech referred to above, the Peruvian state is still at war against an unruly 'nature' and practices that are seen as standing in the way of economic growth and 'progress'. Especially since the 1990s, 
development policies in Peru have been based on a neoliberal model of deregulation, private investment, and extractivism and extensive concessions have been granted to foreign corporations that extract value from nature. The extractive practices that have created most socio-environmental conflicts and have received most attention have been related to the boom in oil, minerals, and logging. Another form of extractivism that is growing in importance in Peru is the extraction of economic value from water in infrastructural megaprojects that are damming and channelling water from the highlands to the arid coast in order to enable large-scale exportoriented corporate agribusiness. One example of these megaprojects is the MIP, which is now going into its second phase, Majes-Siguas II, and which is generating tensions and conflicts.

The expansion of MIP is provoking reactions, for example, from people in the headwater district Callalli where the Condoroma Dam is located and where people have not received any benefits from the dam. The people in Callalli make claims to land areas in Majes based on their asserted ownership to the water that originates in their territory and that enables economic growth in Majes. In this chapter, I explore the conditions that make this land claim possible and discuss how it is connected to notions of belonging and ownership that emerge from particular ontological relations of water, mountains, earth, and human and nonhuman beings. These relations are made through world- and life-making practices and projects, which, although they are often entangled, tend to diverge radically from the projects of modernisation, progress, and economic growth based on extractivism.

Mario Blaser (2004) has argued that indigenous communities do not just resist development and do not just react to state and market; they also sustain 'life projects' that are embedded in local histories and visions of the world and the future that are distinct from those embodied by projects promoted by state and markets. These life projects 'are premised on densely and uniquely woven "threads" of landscapes, memories, expectations and desires' (Blaser 2004: 26). The weaving practices that make the 'threads' in Colca-Majes are what I call world-making practices, or ontological practices, from which humans and other-than-humans (earthmothers, water-mothers, mountain-beings, and other entities) emerge. These practices enact the possibility of fertility, goodwill, and protection as well as the prevention of accidents: the safeguarding of water supply, ensuring the potato harvest, and making sure that the irrigation canals and ponds will endure and work well (see also Stensrud 2016). I see 'reality' as not preceding the mundane practices in which we interact with it but 
rather as being shaped and enacted in these practices (Mol 2002). This analytical lens entails seeing emergence instead of relations between bounded 'units' of indigeneity and modernity (de la Cadena 2015a). A dynamic approach that focuses on life projects, world-making practices, and what emerges from them can contribute to a more nuanced understanding of reactions and interactions within a megaproject like MIP.

While life-making projects in the Andes are constituted by relational practices of reciprocity, extractivist projects come from a colonial practice of conquest. I argue that extractivist policies and practices that support megaprojects like MIP are radically different from life-making projects that consist of maintaining a livelihood of small-scale farming by interacting with water and other earth-beings. Extractivist and life-making projects can be intrinsically entangled in practice-for example, some farmers who work for MIP or in mines participate in both extractivist and lifemaking projects - and all uses of water imply different kinds of appropriation. Yet, I maintain that a logic based on extractivism and conquest is not compatible with the logic of relationality and reciprocity. Megaprojects are projects of modernity and hence coloniality, which is not only the heritage of colonialism but is constitutive of modernity (Mignolo 2000; Escobar 2007; Maldonado-Torres 2007). Coloniality is a discourse and practice that simultaneously preach the natural inferiority of subjects and the colonisation of nature, which mark certain subjects as dispensable and nature as pure raw material for the production of goods in the international market (Maldonado-Torres 2007: 135). Coloniality can be understood as the radicalisation and naturalisation of the non-ethics of war, representing a sort of exception to the ethics that regulate normal conduct, which justify slaving and eliminating dispensable subjects (Maldonado-Torres 2007: 138). The idea that certain people are dispensable can be seen as deriving from an unrecognised implication of Descartes' cogito ergo sum: 'I think (others do not think, or do not think properly), therefore I am (others are-not, lack being, should not exist or are dispensable)' (MaldonadoTorres 2007: 144). Hence, to not think 'rationally' according to a paradigm of efficiency and 'progress' is made into a sign of nonbeing in modern society where profitability and economic growth are more important than ways of maintaining life projects and worlds that are categorised as 'other'. The subjects that are rendered dispensable in Peru comprise not only indigenous subjects but also other-than-human beings, including earth- and water-beings. When water is appropriated to extract economic value, it is part of a practice that not only colonises water as resource but also water practices that diverge from the logic of extractivism. 


\section{Conquering Water}

In the 1970s, MIP was considered 'the world's most expensive irrigation project' (CIP 2013), and the total investment was USD 630 million, 35 per cent of which was financed by the state (Zamalloa 2013: 38). The rest was financed by international loans, and the infrastructure was built by the consortium MACON (Majes Consorcio), consisting of five private companies from Sweden, England, South Africa, Canada, and Spain. MACON built the Condoroma dam in Callalli District, the downriver water intake in Tuti District, and the Canal Majes: 88 kilometres of tunnels and 13 kilometres of open canal through the districts of Tuti, Chivay, Yanque, Achoma, Maca, Cabanaconde, and Huambo. The execution of the MIP was started during the left-wing regime of Velasco (1968-75), who endeavoured to bring Peru into an era of progress: the 1969 agrarian reform ended the dominant power of the large estate owners in the highlands (Collier 1978) and the same year water was nationalised by the General Water Law (Ley General de Aguas) (del Castillo 1994). Velasco's reforms were intended to help poor indigenous peasants but mainly focused on class and socio-economic issues and did not include indigenous designs and multiple life projects.

The construction phase, which the CEO called a 'war against nature', is remembered by many people in Colca Valley as a time of rapid change and intrusive encounters. In 1972, construction began on the water intake in Tuti and Majes Canal. MACON brought specialists from all over the world and workers from other parts of Peru, who were stationed in an encampment in Achoma District. In the years that they lived and worked there, the MACON workers, and especially the foreigners, were highly visible in Colca. 'That was the first time we saw gringos; there was no tourism yet', a man in his 50s commented. His name was Edwin and he told me that when he had been a young boy in the 1970s, the MACON gringos, also called 'los macones', used to drink in his father's cantina (tavern). 'Los macones have done whatever they wanted here', he commented. According to Paul Gelles, who did fieldwork in the community of Cabanaconde in the 1980s, most local people lamented the changes and abuses the project brought; stores were opened to meet the demands from a booming economy and 'everything became money'. The MACON workers abused the local people, and there were incidents of prostitution and rape (Gelles 2000: 61).

MACON offered temporary jobs to local men-low-paid manual labour in the construction of the dam, the water intake, the canal, and tunnels. This work was dangerous and many lives were lost in the tunnels and the construction sites. One of Edwin's relatives was killed in an accident in Tuti 
when his poncho got stuck in the machinery at night. In the eyes of local people, MACON challenged the respect for the powerful mountains as they used dynamite to make the Majes Canal and the tunnels, and it was, therefore, necessary to make offerings (pagos) to avoid accidents. Accidents are often talked about as being eaten by hungry mountains, or being lured by beings inside the mountains, called devils or chinchilikos. Old farmers who had worked as labourers in the making of tunnels remembered the chinchilikos: small underground creatures, also called dwarfs, devils, miners, or just 'small men with helmets', who appeared inside the mountains. ${ }^{2}$ By offering you gold and silver, they can drag you inside the mountain and make you disappear. The daughter of a man who had met a chinchiliko in the Majes tunnel told me that when the devil drags you (te jala), it is the same as when the mountain eats you. In southern Andean Peru, it is a common practice to pay offerings and ask earth-beings for permission to make roads, tunnels, and mines (cf. Harvey and Knox 2015). Although this was not (and could hardly be) part of the official work strategy of MACON, I was told that MACON workers also engaged in such practices. For example, Edwin told the story of a poor beggar who suddenly disappeared. A rumour was spread that the MACON workers had sacrificed him to the mountain to avoid accidents. According to the rumour, they had made him drunk and after he had passed out, they put him in the pago and buried him alive. I also heard that 'they put a human foetus in the pago' before starting the construction of the water intake in Tuti, but it was never made clear to me who 'they' were. It could very well be that both local people and MACON workers from other parts of highland Peru wished to reduce the risk of fatal accidents.

These stories are not testimonies that give precise details about the past but serve to explain how situations and relations are perceived and how connections are made. The stories have broad resonance in the ethnographic literature from the Andes, for example, in Nash's (1979) study of how mine workers in Bolivia relate to el Tio-also associated with the devil-who is the owner of the mountain and who they must give offerings to before taking out minerals (see also Fernández Juárez 2013). In Taussig's interpretation, offering to el Tío as the devil of the mine is a reaction to capitalist modes of production. In the precolonial Andes, there was no conception or reification of an evil spirit: 'evil was neither reified nor fetishized, neither a thing opposed to good nor a thing spiritualized like the devil' (Taussig 1980: 169). The fetishisation of evil in the form of the devil was created after the Spanish Conquest, along with the new forms of class oppression (Taussig 1980). The earth-beings had to assimilate to the Christian religion or descend underground to the world within/below called ukhu pacha in order to become 
invisible, and some of these beings were identified with the devil (Cereceda 2006). Rather than understanding the chinchiliko as a symbol of Christian or capitalist oppression, I see it as an entity that emerged in encounters between worlds of different nature-culture constellations: a relational world where all living beings are connected versus a 'modern' world where nature is seen as a resource to be exploited or as a container from which value can be extracted.

In the dominant discourse of modernisation and progress, indigenous practices are ridiculed and seen as 'ancient' customs that should be eradicated because they are hindering progress and economic growth. This view was publicly stated by President Alan García in an interview on national television in 2011:

[We] must defeat the absurd pantheistic ideologies that believe that walls are gods, that the air is god, the return to these primitive forms of religion, where they say do not touch that mountain because it is an apu and full of a millenarian spirit [...]. That we are advancing does not mean that all our ancient forms of thought have been overcome. (Los Andes 2011)

The encounters with sentient mountains and chinchilikos are not part of the official story of the Majes Project. As in other official histories of extractivist 'development' in the Andes, the earth-beings are denied real existence or are tolerated as indigenous belief or superstition (de la Cadena 2015a, b). Yet, in Colca, the stories are told again and again. The arrival of MACON in Colca Valley was, and still is, perceived as a powerful intrusion that disrespected local people as well as the living mountains. Lifemaking projects that interact with earth-beings are not remnants from an ancient past but are continuously sustained and re-invented in light of globalisation and changing environmental conditions.

\section{RESPECTING WATER}

The Tuti intake station directs water that would normally flow down the Colca River into the Majes Canal. Since the river runs in the deep Colca Canyon, the farmers have never used this water for irrigation. Today, farmers take water from valves in the large Majes Canal, which are connected by small canals to the old network of irrigation canals in the valley. Irrigation has always been important in the arid Colca Valley, but it becomes even more crucial with the shortened rain seasons that farmers have experienced in the past few years. Making irrigation systems work requires the maintenance of physical infrastructure as well as different kinds of relationships: 
cooperation within and between communities and the goodwill of the mountains and springs that supply the water. The work of the 33 irrigation associations of the valley, called water users' commissions (comisiones de usuarios), and of the Water Users' Board of Colca Valley (Junta de Usuarios Valle de Colca) is very important in this regard. The approximate ten thousand smallholding farmers in Colca Valley are organised in these associations. They are proud of their hydraulic infrastructures, which constitute a complex network of hundreds of kilometres of canals and pipes that connect the springs, lakes, glaciers, ponds, and small reservoirs with the pastures and fields. While the large-scale Majes Canal is maintained by AUTODEMA (Autoridad Autónoma de Majes), the state entity in charge of MIP, the small-scale infrastructure is built and maintained in collective work parties, where all water users are obligated to participate in order to have the right to use water. Every August, which is the month before the start of a new sowing season, each association organises the main cleaning of their irrigation infrastructure followed by festive celebrations.

The irrigation systems necessitate cooperation between communities. For example, the village called Yanque must bring water from the neighbouring districts. Each year, in August, they organise collective work to clean the long irrigation canals from the Huarancante mountain in Chivay and the Canal Mismi, which goes 25 kilometres from Mount Mismi in Tuti District, through Coporaque District and down to Yanque. The cleaning work takes four days for the group of farmers who go up to the source and descend by foot while they clean the canal with shovels. Before starting the work, it is important to make pago to the mountains so that no accidents or deaths will happen. Proper offerings also have to be made to the ponds and canals that are going to be cleaned and repaired. The night before cleaning the main pond in Coporaque, in 2011, the two water users' commissions each made a pago to the pond. They put the pagos in a box buried deep in the earth beside the gate, where they also keep small miniatures of llamas that are taken out to be 'read' and interpreted before they are returned. The wine goblet should be empty - this means that the earth-mother of this place and this pond is content-before it is filled with new wine. According to Catherine Allen, ritual practices in the Andes are 'premised on a principle of consubstantiality, the assumption that all beings are intrinsically interconnected through their sharing a matrix of animated substance' (Allen 1997: 75). Hydraulic infrastructure, such as ponds and canals, cannot be seen as separate from the entangled world of soil, water, earth-beings, and other animated entities in the surroundings. After the work is finished, all participants celebrate with food, drink, and dance. When the water, which has been withheld during the work, 
is released, it is received with reverence and joy. Farmers in Yanque and Coporaque celebrate the water when it arrives in the cleaned canals and ponds; people drink the water, pour chicha (maize beer) into it, and dance around the canals and inside the pond while playing festive music. Different variations of these festivals of cleaning the irrigation canals take place in all the communities of Colca Valley.

In these world-making practices, water emerges as a sentient and responsive entity and 'a living being' (Valderrama and Escalante 1988: 206). Farmers in Chivay usually call water by its common name Yakumama, which means water-mother, and they also use the name Mama Choqueshisha 'out of respect' (de respeto). Water is known as a female life source that connects humans, plants, animals, and spirits. Water-beings such as lakes and springs (qochas and pukyos), as well as the earth-mother (pachamama), mountain-lords (apus), and other placebeings in the Andean landscape that are often called earth-beings (tirakuna) (Allen 2002; de la Cadena 2015a) are not inherently benevolent or malevolent, but they are very demanding and can be quite capricious. They demand proper respect and gifts (pagos) in return for water, plants, fertility, and well-being (see also Ødegaard, this volume). These pagos usually consist of llama foetus, sugar, fat, food, alcohol, coca leaves, flowers, miniatures and other items. Offering pagos —also called iranta ${ }^{3}$ in Colca - to the earth-mother, mountains, and water springs is an intrinsic part of agricultural and irrigation practice in Colca Valley. When the environment, the weather, and the water supply change, the need for making pagos becomes evermore pressing, in order to secure the continued provision of water from the mountains.

During the past 20 years, it has become increasingly difficult to maintain a livelihood as a small-scale farmer in Colca because of tough market competition as well as harsh weather conditions that are increasingly explained by climate change. The changing climate translates into unstable seasons and extreme temperatures, in addition to water-related problems: decreasing water supply in the springs, dry pastures, and irregular rain. The changing weather and insecure water supply increase the importance of pagos/irantas to mountains and springs. In August 2011, I was invited to accompany a group of men from one of Chivay's three water users' commissions-who were going up to the mountains to make irantas to the high springs, located above 4000 metres of altitude. By each spring, the paqu (ritual expert) prepared the ingredients to an iranta, and we all participated by rolling balls of fat from llama (lama glama) called untu and making bouquets of coca leaves (erythroxylum coca) called k'intus, into 
which we blew our samay (breath, life-essence, vital force) while invoking the names of various beings: the place, the spring, the Lord Santiago who controls the lightening (so that he would not send a lot of lightening, but only rain), and finally the machulas (ancestors). Before burning the iranta, the paqu summoned the water (llamar al agua). He used seawater that had been brought in a bottle all the way from the Pacific Ocean, which he placed inside the spring. The paqu told me that the seawater 'will call for more water'. After burning the iranta, the paqu placed tiny ceramic goblets with chicha, sweet wine, and holy water in a box in the earth beside the spring. He explained: 'It is for here, for the spring, to drink. This will be preserved here and it is for the whole year. It is ... how should I put it ...-it is [her] pago. Like we sometimes toast [drink], they are also thirsty.' In local practices and narratives, springs, mountains, and other earthbeings have names and personal characteristics, and they can feel thirst, hunger, and respond to human action. ${ }^{4}$ Hence, through these ritual actions, water and water-beings are enacted as living nonhuman persons. To acknowledge the presence of these beings through what is locally talked about as 'respect' is part of living and making life in Colca today (Fig. 6.1).

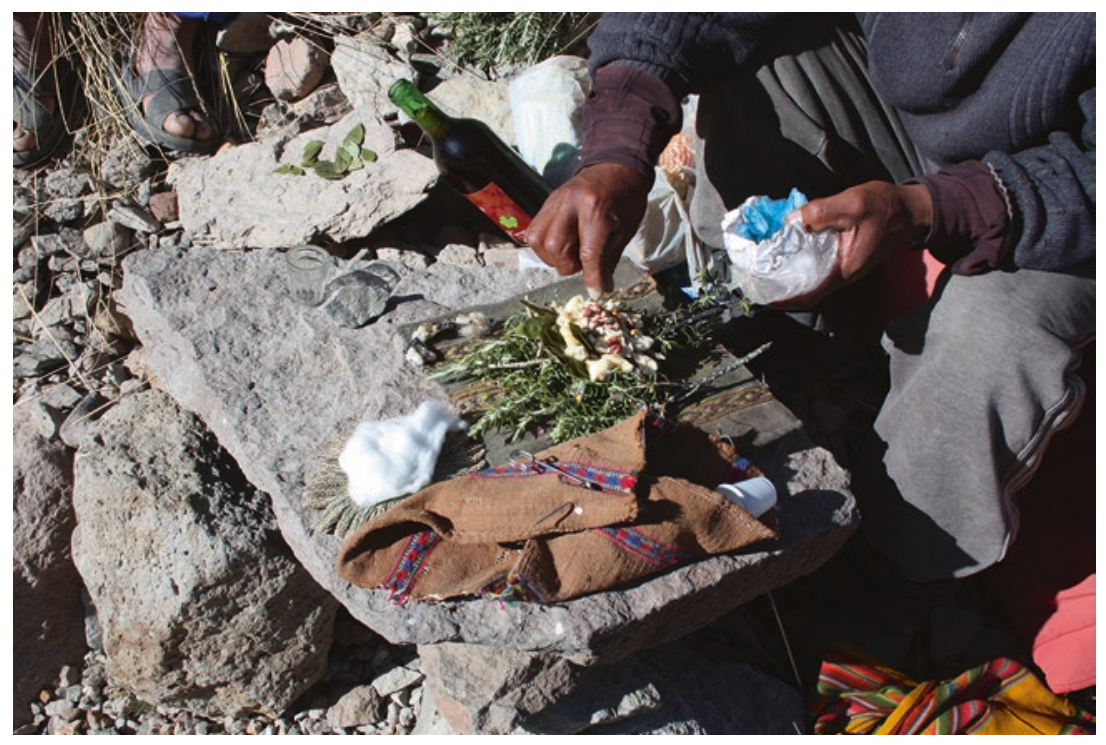

Fig. 6.1 A pago is prepared nearby a spring, with herbs, coca leaves, llama fat, and a dried star fish 


\section{Measuring Water}

With Canal Majes, the farmers living at the 'left riverbank' (la margen izquierda) in Colca Valley got a new source of water, but they did not achieve access without a fight. When the Canal Majes was completed in 1982, the farmers in Colca suffered from an extreme drought while they watched the water being channelled across their fields. Their petitions to the government, where they solicited access to this water, were ignored. Only after a group of 11 men from the village of Cabanaconde took action and blew a hole in the canal with dynamite, did the communities along the canal get access to the water to irrigate their lands. These men are still honoured as the 'eleven heroes' in Colca Valley (Gelles 2000). Today, the main marker of difference between the left and right side of the river valley relates to water access and agricultural production. While the farmers living at the right bank of Colca River (la margen derecha) continue to struggle with water scarcity, some farmer communities at the left riverbank have expanded their areas of cultivation with the allocated water from the Majes Canal. However, the water is not free of charge. Today there are 26 valves in the canal from which farmers in the villages Canocota, Chivay, Yanque, Achoma, Maca, Pinchollo, Cabanaconde, and Huambo are allocated regulated amounts of water. The water going into the Majes Canal in Tuti is regulated by AUTODEMA. The amounts are decided in monthly meetings where AUTODEMA, the state water administration, and the affected water users' organisations negotiate the distribution of water according to the supply in the Condoroma Dam and the farmers' demands in Majes and in Colca Valley. The valves are adjusted to a specific flow rate measured in litres per second, and there is a monthly valve regulation (regulación de válvulas) where the AUTODEMA engineers inspect the valves in the Majes Canal to ensure that the farmers do not use more water than they are allowed.

Since the 1990s, farmers have been obligated to pay a tariff for the irrigation water to the Water Users' Board (Junta de Usuarios), which is a private nonprofit association that is responsible for the maintenance and operation of the small-scale hydraulic infrastructure. The tariff is calculated according to land size and source: whether it is regulated water from the Majes Canal, unregulated water from natural springs and streams, or mixed water from both sources. The tariffs are not payments for the water per se, since water is public property by law, but for the use of infrastructure. Therefore, the water coming from the Majes Canal is the most expensive (between 26 and 40 soles a year per hectare), while unregulated water is cheap in comparison (between 12 and 15 soles). The Junta pays 
AUTODEMA, which is responsible for the maintenance of the Majes Canal, for the regulated water. All farmers in Majes pay the most expensive tariff for regulated water, while a farmer in Colca might pay both categories for the irrigation of different fields. Since 2006, farmers also have to pay an annual fee for a water licence, which is a formalised and permanent water use right for an amount of water measured in litres per second from a specific source. Registration and control require a simplification of nature to make it more susceptible to measurement, calculation, and manipulation, and this bureaucratic logic of legibility is practically synonymous with, or a requisite of, a commercial logic (Scott 1998). This means that the complexity of water-beings, water practices, and relationships is reduced into a uniform 'resource' that can be exploited for economic gain.

The payments came as a result of the liberalisation of markets that took off in the 1990s, when the Fujimori regime implemented massive privatisation and economic deregulation. The neoliberal restructuring and reduction of the state entailed a reversal of the agrarian reform-the cancellation of subsidies to farmers, and the removal of protectionist laws, allowing unlimited private property (Mayer 2009). The neoliberal Fujimori government failed at privatising water, but during the 1990s the staff of the water administration was reduced, and state functions in operation and maintenance of the irrigation infrastructure were handed over to the user organisations (Oré and Rap 2009). Hence, the water user commissions and the Junta in Colca were given more responsibilities and started charging the farmers a water tariff. In 2009, the García government passed the Law on Water Resources (Ley de Recursos Hidricos), which emphasises the economic value of water and the need for efficiency and modernity in water management (ANA 2010). The law gives ample space for private companies to intervene and invest in water management (del Castillo 2011).

The concession to construct and administer the second phase of MIPcalled Majes-Siguas II-has been awarded to a Spanish-Peruvian private consortium called Angostura-Siguas. Since the consortium will administer the canal for 20 years, the farmers in Majes and Colca fear that they will increase the water tariff to recover their investments. 'We call this privatisation', farmers repeatedly said. No matter how strongly the government argues that the water will still be public property, the farmers fear that the operator that administers the infrastructure will control the water flow. Additionally, they anticipate that big corporations, which are able to pay more for the water, will buy most of the land in Siguas. While the land in the first phase of Majes was sold in units of 5 hectares to subsidised prices, the land in Siguas will be sold in units of 200, 500 and 1000 hectares in 
order to attract big capital and ensure that large-scale export-oriented agribusiness will create economic growth. The annual goal is to generate USD 360 million from exports, which will substantially increase the agricultural GDP (Huanca 2014).

The Majes-Siguas II is highly promoted as a project for the future: for modernisation, progress, and development. In his speech for the inauguration of Majes-Siguas II in the pampa of Siguas on 6 February 2014, President Ollanta Humala promised a modern export-oriented agriculture where large-scale agribusiness corporations would create employment for 200,000 people and spur economic growth for the whole region (Campano 2014). The water for the expansion of the irrigated areas in Majes-Siguas II-38,500 hectares in the pampa of Siguas (adjacent to Majes)—will come from the planned Angostura Dam. Since 2009, farmers in the highland province of Espinar, in Cusco region, have protested against the Angostura Dam contending that it will leave them with less water. Espinar receives water from the headwaters of the Apurímac River Basin, which are the same sources that will feed Angostura. In 2011, the constitutional court stopped the project and ordered a new environmental impact assessment and water balance report. After the new report in 2013 had concluded that there is enough water, based on quantitative measurements of water resources, the court allowed the USD 550 million project to proceed as planned. The construction of the dam was supposed to start in April 2016, but the consortium and the regional government are still negotiating compensation and the value of land owned by farmers in Pusa Pusa. On the negotiating table are not only money but also the possibility of receiving land in Majes and also training in how to make a livelihood in a new environment.

While Majes is growing due to a booming economy, entrepreneurial activity, and population growth, the provincial capital Chivay and the other villages upriver in the Majes-Colca watershed experience a declining agriculture, decreasing water supplies, and out-migration of young people. The pastoral farmers in the headwaters are the first to experience the consequences of climate change and the last to get access to the benefits from infrastructural megaprojects of 'development'. In 2012, there were heated discussions about why Chivay should continue to be the capital of the Caylloma province, and the population of Majes wanted to separate from Caylloma to become a province apart. A couple of days after this had been publicly stated, the Majes Canal broke because of an earthquake in Colca Valley. When the water did not arrive in Majes, it caused a sense of crisis and made explicit the vulnerability of the place. Miguel, who worked for the Water Users' Board, suggested: 'It seems like the nature got annoyed. Like 
a sign, a message: that Majes depends on the highlands.' In modern discourse, such explanations are not possible; they are ridiculed, ignored, or at best patronised or 'tolerated' as culturally peculiar or silly jokes. Miguel was very much aware that from a scientific perspective, there is no nature with sentience and intentional agency, and he showed this in our conversation through moderating his statement by saying 'it seems like'. Miguel was born and raised in Chivay and had studied engineering at the University of Arequipa. As an engineer working with water management, he participates in the world of science, but he also participates in practices that make other worlds emerge: for example, he is cautious when approaching particular springs because they have life and powers. This shows the complexity of contemporary life in the Andes, where 'indigenous' and 'modern' worlds are not separate units but emerging realities and always overlapping (see also Stensrud 2016). However, despite his cautious qualification, he was not joking. On the contrary, he was deeply concerned about the importance of seeing and managing the whole watershed, including the headwater environment, the river, and the infrastructure. In Miguel's opinion, AUTODEMA has done what they wanted in the high parts of Caylloma without asking permission from local water authorities in order to lead water to Majes. According to the extractivist logic that sees water only as economic resource, the government prioritises the irrigation project in Majes because this is where the water's value is being exploited most efficiently and profitably. However, water cannot be treated as disconnected from the watershed and all its relationships along the river and canal. Water has always been highly valued in Colca, yet after the construction of the Majes Canal, the value of water has gained new economic and political meanings.

\section{Claiming Water}

The district of Callalli, where the Condoroma Dam is located, has not increased its supply of water as a result of MIP and does not receive any compensation for the water that is channelled down to Majes. The 2500 inhabitants in Callalli (called callallinos), just as people in the rest of the Colca-Majes headwaters above 4000 metres of altitude, are among the poorest in the region as they struggle to make a living on alpaca pastoralism, selling the wool and meat to wholesalers. Their harsh mountain environment is the most impacted by climate change: according to local authorities and farmers, glaciers have disappeared, springs have dried out, pastures are dry, the rain is more irregular, and when it finally comes, it 
falls so hard that it erodes the soil (Stensrud 2015). The incidents of strong frost periods and heavy snowfall are more common than before and harder to anticipate, and the local authorities have declared states of emergency in the high parts of Caylloma province almost every year since 2011.

The callallinos have been inspired by the protesters in Espinar because although they did not stop Majes-Siguas II, they were conceded compensation in the form of financial support to local infrastructure and other projects. In 2012, a group of 300 families from Callalli organised a collective claim to get the legal property rights to 400 hectares of arid land in Majes as well as infrastructure and water to irrigate and produce on this land. They claim that callallinos have the right to land and water in Majes because they belong to the headwater territory where the water comes from-the water which enables the export agriculture and economic growth in Majes. Hence, the water-and, by extension, the fertility of the land-also 'belong' to the headwaters in Callalli where it originates. Economy and production in the Andes have traditionally been organised vertically, which means that several ecological zones at different altitudes belong to the same community (Fonseca Martel 1972; Murra 2002).

In 2013 and 2014, while they were waiting for a response to the formal request, the callallinos appropriated the land by planting rows of trees along its borders. They visited the place regularly to water the plants and in this way cared for and nurtured the land. The claim for compensation for water echoes the environmental justice movement, in Latin America, also called 'ecologism of the poor', which addresses conflicts about unequal access to nature's services and resources and connects economic and ecological distribution to political power (Martínez Alier 1992). The callallinos take seriously the law on water resources, which gives priority to water's economic value and use this to justify their claim. However, there is another dimension to the claim that goes beyond political ecology; it emerges from world-making practices and life projects that open up for disagreements on the definition of nature and the world itself. When these ontological disagreements are brought into the public eye through such claims, it allows for pluriversal politics to unfold (Blaser 2009; de la Cadena 2010).

Victor, the initiator and leader of the group of claimants from Callalli, told me that if they did not get their land claim through, they would make a water war because 'we are the owners of the water! ... [we are the] owners of the earth, owners as cayllominos which is who we are because these lands belong to Caylloma'. Their claim of water ownership is based on the notion that water is conditionally given to them by the mountains, 
called apus (lords), who are powerful beings that guard the territories that they overlook (Gose 1994; Gelles 2000; Allen 2002). The gift of water is not permanent and cannot be taken for granted: the relationships of reciprocity and guardianship have to be reaffirmed each year through pagos and other ritual work. The mountain-lords can be vengeful and dangerous when they are disrespected or have not received offerings. Hence, living in this place implies taking part in intricate and affective relationships between humans and mountains, earth and water. Relationships to land and water have to be nurtured in order to ensure water supply and fertility of land and animals. Through these actions, humans are endowed with the right to use the water emanating from the land. This is translated as 'ownership', which in this case is processual and dynamic and based on care, nurture, and reciprocity, similarly to how it is practised in Amazonia (Brightman et al. 2016; see also Brightman, this volume). Since water comes from the mountain-lords who are its keepers, it also belongs to the territories and the people of which the apus are guardians.

Although this way of explaining belonging and ownership is very different from how property is established according to the state and the market, and although many are critical to neoliberalism and extractivism, the claim is not in opposition to the government. These callallinos are not aiming to stop the neoliberal and extractivist policies. Rather, they wish to be recognised as being part of the watershed and as having rights to water and land. They want to have a part of the benefits from MIP but according to their own terms. Víctor said: 'We have not come to beg for charity from anyone; on the contrary we come to contribute, we want to invest here.' What they are asking for is legitimate access to possibilities to invest, work, and produce. The deputy mayor of Callalli told me that the rearing of alpacas in Callalli and the cultivation of fodder in Majes are complementary activities; when there is scarcity of water and grass in the highlands, they can send fodder from Majes. In this way, the project is also about practising the vertical way of organising production across several ecological niches of different altitudes as it has been done in the Andes for centuries (Fonseca Martel 1972; Murra 2002).

When farmers and herders from the headwaters protest against the uneven distribution of resources, they are also demanding to be heard according to their own notions of ownership, belonging, and investment, which are embedded in particular ontological relationships. In the highlands, many farmers participate in giving offerings to the mountains as suppliers of water. In other words, people invest time and work in making 
territory where land, water, humans, animals, mountains, and infrastructure are connected in a relational web. From this territorial web emerges a form of ownership that exceeds the dichotomies of private versus public, individual versus collective, as well as the possessing subject versus the possessed object (cf. Brightman et al. 2016). Since the formal claim is clearly based on the political economic notion of the economic value of water resources and of compensating water for land, the callallinos have a chance to be heard. The outcome was still uncertain when this text was written, yet the municipality of Callalli have made new demands for land in the second phase, Majes-Siguas II (El Pueblo 2017). However, the legitimation for the claim in ontological relations between mountains, water, territories, and people is unheard of in public arenas. Although it is implied in the land claim, what is not seen-or not shown-in the formal paperwork is that water is a living being and a vital life-giving force that comes out of the sentient and powerful mountains. The practices that enact water as a sentient being are not yet part of a strategy to oppose or influence the government, although they are part of life- and world-making projects to sustain life, livelihood, and the relational web of the world.

\section{Conclusion}

Environmental conflicts in Peru often entail encounters between different kinds of knowledges and practices, as in the struggles against the Yanacocha Mine in the northern Peruvian highlands and against the mining concession in Mount Ausangate in Cusco (de la Cadena 2010; Li 2015). Hence, mountains can be included as earth-beings with agency in struggles against extractivist projects, which transforms these struggles into pluriversal politics (de la Cadena 2010). The state tends to see indigenous and/or local life-making and world-making projects as obstructions against development that should be overcome by education, economic persuasion, or force. This hegemonic view was most explicitly articulated by former President Alan García, who, in 2007, made social protests and strikes illegal. García accused the opponents of private investments for obstructing progress due to old ideologies, laziness, and inertia and because of the 'demagogy and deception that say that these lands cannot be touched because they are holy objects' (García Pérez 2007). Hence, earth-beings are only paid attention to as remnants of ancient beliefs and 'holy objects' that are allegedly used to obstruct progress. However, as shown in this chapter, earth-beings are not (only) employed as part of an indigenous 
strategy to stop extractivism, but they are part of relationships that are being continuously nurtured as part of ongoing life projects. In public discourse, the everyday relationships and encounters with existing earthand water-beings are silenced and made invisible; they are the 'anthroponot-seen' (de la Cadena 2015b). Therefore, the encounters with chinchilikos and the celebrations of the water-mother yakumama are not part of the official story of MIP. The Peruvian government's hegemonic project is to achieve development, progress, and economic growth through modernisation and extractivism. This involves making water modern, that is, to transform the multiplicity of water into a standardised and neutral substance that can be extracted as an economic resource and transformed into products and profits. The modernising project also entails creating a coherent and legible land- and waterscape that can be measured, registered, and controlled by the state. Hence, modernised water as economic resource is colonialised water. This extractivist and modernising/colonising project is not compatible with sustaining world-making and lifemaking projects, in which water is multiple and ontologically different. Water as a living being and as a gift from the mountains cannot be easily 'scaled up' and transformed into a homogenous, legible, and commercialised resource. Seeing water not as universal but as constituted in practice, allows us to perceive water and the world itself as emerging, as always becoming in different versions, and as multiple realities.

Acknowledgements The research leading to this chapter has received funding from the European Research Council (ERC Grant Agreement number 295843) and the Research Council of Norway (NFR project number 222783). The author would like to thank Juan Javier Rivera Andía and Cecilie Vindal Ødegaard for their insightful and critical comments on this chapter.

\section{Notes}

1. In this chapter, Majes is the name of the arid pampa between the river valley of Majes and the river valley of Siguas, and it is also the name of the irrigation project in this pampa and the name of the irrigation canal leading water from the Colca River. Majes is further the name of the new district that was created in 1999 as part of Caylloma Province in Arequipa Region.

2. The chinchilikos seem to be very similar to the muki, which has been described in ethnographies from the central Andes, see, for example, SalazarSoler (1987). 
3. The anthropologists Valderrama and Escalante (1988: 109) translated iranta as 'food for the gods'. According to the Quechua-Spanish dictionary of Academia Mayor (2005), the verb irantay means to fill a special container with grease for the pago to Pachamama. According to Adelaar (2004: 278), a translation from Aymara would be 'to introduce small objects'.

4. There are similar ritual practices related to water in various places in the Peruvian highlands. See, for example, Borea Labarthe (2004).

\section{REFERENCES}

Academia Mayor de la Lengua Quechua. 2005. Diccionario Quechua-EspañolQuechua. 2nd ed. Cusco: Gobierno Regional.

Adelaar, Willem F.H. 2004. The Languages of the Andes. Cambridge: Cambridge University Press.

Allen, Catherine J. 1997. When Pebbles Move Mountains. Iconicity and Symbolism in Quechua Ritual. In Creating Context in Andean Cultures, ed. R. HowardMalverde. New York: Oxford University Press.

- 2002. The Hold Life Has. Coca and Cultural Identity in an Andean Community. 2nd ed. Washington, DC: Smithsonian Institution Press.

ANA (Autoridad Nacional del Agua). 2010. Ley de recursos hidricos y su reglamento. Ley No 29338. Lima: Ministerio de Agricultura.

Blaser, Mario. 2004. Life Projects: Indigenous People's Agency and Development. In In the Way of Development. Indigenous Peoples, Life Projects and Globalization, ed. Mario Blaser, Harvey A. Feit, and Glenn McRae. London: Zed Books.

- 2009. The Threat of the Yrmo: The Political Ontology of a Sustainable Hunting Program. American Anthropologist 111 (1): 10-20.

Borea Labarthe, Giuliana. 2004. Trás los pasos del parian en el evento y en el tiempo. Imagenes y representaciones en la sierra de Lima. Anthropológica 22 (22): 151-178.

Brightman, Marc, Carlos Fausto, and Vanessa Grotti. 2016. Introduction. Altering Ownership in Amazonia. In Ownership and Nurture. Studies in Native Amazonian Property Relations, ed. Marc Brightman, Carlos Fausto, and Vanessa Grotti. New York: Berghahn Books.

Campano, Magaly. 2014. Majes Siguas II es un proyecto importante para el desarrollo del país. Diario Correo, February 6. https://diariocorreo.pe/ciudad/ majes-siguas-ii-es-un-proyecto-importante-p-52711/. Accessed 19 Dec 2017.

Cereceda, Verónica. 2006. Mito e imagines andinas del infierno. In Mitologías Amerindias, ed. Alejandro Ortiz Rescaniere. Madrid: Editorial Trotta.

CIP (Colegio de Ingenieros del Perú). 2013. Ambicioso y esperado proyecto multipropósito Majes-Siguas II. Ingeniería Nacional. Revista Oficial del Colegio de Ingenieros del Perú, Consejo Nacional 3 (12): 40-42.

Collier, David. 1978. Barriadas y élites: de Odría a Velasco. Lima: IEP. 
de la Cadena, Marisol. 2010. Indigenous Cosmopolitics in the Andes: Conceptual Reflections Beyond 'Politics'. Cultural Anthropology 25 (2): 334-370.

- 2015a. Earth-Beings. Ecologies of Practice Across Andean Worlds. Durham: Duke University Press.

- 2015b. Uncommoning Nature. http://supercommunity.e-flux.com/ authors/marisol-de-la-cadena/. Accessed 16 Sept 2015.

del Castillo, Laureano. 1994. Lo bueno, lo malo y lo feo de la legislación de aguas. Debate Agrario 18: 1-20.

- 2011. Ley de Recursos Hídricos: Necesaria pero no suficiente. Debate Agrario 45: 91-118.

El Pueblo. 2017. Callalli también pide terrenos en proyecto Majes-Siguas II. El Pueblo, March 2. http://elpueblo.com.pe/noticia/locales/callalli-tambienpide-terrenos-en-proyecto-majes-siguas-ii. Accessed 15 Oct 2017.

Escobar, Arturo. 2007. Worlds and Knowledges Otherwise. Cultural Studies 21 (2-3): 179-210.

Fernández Juárez, Gerardo. 2013. El ‘Tío’ está sordo: Los mineros bolivianos y el Patrimonio Cultural Inmaterial. Revista de Antropología Iberoamericana 8 (3): 303-322.

Fonseca Martel, Cesar. 1972. La economía 'vertical' y la economía de mercado en las comunidades alteñas del Perú. In Visita de la Provincia de León de Huánuco en 1562, ed. John V. Murra and Ortiz de Zúñiga, vol. 2. Huánuco: Universidad Nacional Hermilio Valdizán de Huánuco.

García Pérez, Alan. 2007. El síndrome del perro del hortelano. El Comercio, October 28. http://elcomercio.pe/edicionimpresa/html/2007-10 28/el_ sindrome_del_perro_del_hort.html

Gelles, Paul H. 2000. Water and Power in Highland Peru: The Cultural Politics of Irrigation and Development. New Brunswick: Rutgers University Press.

Gose, Peter. 1994. Deathly Waters and Hungry Mountains: Agrarian Ritual and Class Formation in an Andean Town. Toronto: University of Toronto Press.

Harvey, Penny, and Hannah Knox. 2015. Roads. An Anthropology of Infrastructure and Expertise. Ithaca: Cornell University Press.

Huanca, Elizabeth. 2014. Así funcionará la segunda etapa del proyecto Majes Siguas. La República, February 10. http://larepublica.pe/archivo/771336-asifuncionara-la-segunda-etapa-del-proyecto-majes-siguas. Accessed 30 Nov 2017.

Li, Fabiana. 2015. Unearthing Conflict: Corporate Mining, Activism and Expertise in Peru. Durham: Duke University Press.

Los Andes. 2011. Ignorancia de García Pérez califica de absurdas creencias andinas (Video). Los Andes, June 17. http://www.losandes.com.pe/ Nacional/20110617/51373.html. Accessed 5 May 2017.

Maldonado-Torres, Nelson. 2007. Sobre la colonialidad del ser: contribuciones al desarrollo de un concepto. In El giro decolonial. Reflexiones para una diversi- 
dad epistémica más allá del capitalismo global, ed. Santiago Castro-Gómez and Ramón Grosfoguel. Bogotá: Iesco-Pensar-Siglo del Hombre Editores.

Martínez Alier, Joan. 1992. De la economía ecológica al ecologismo popular. Barcelona: Icaria.

Mayer, Enrique. 2009. Ugly Stories of the Peruvian Agrarian Reform. Durham: Duke University Press.

Mignolo, Walter D. 2000. Local Histories/Global Designs: Coloniality, Subaltern Knowledges, and Border Thinking. Princeton: Princeton University Press.

Mol, Annemarie. 2002. The Body Multiple: Ontology in Medical Practice. Durham: Duke University Press.

Murra, John V. 2002. El Mundo Andino: población, medio ambiente y economía. Lima: IEP/Pontificia Universidad Católica del Perú.

Nash, June. 1979. We Eat the Mines and the Mines Eat Us: Dependency and Exploitation in Bolivian Tin Mines. New York: Columbia University Press.

Oré, María Teresa, and Edwin Rap. 2009. Políticas neoliberales de agua en el Perú. Antecedentes y entretelones de la ley de recursos hídricos. Debates en Sociología 34: 32-66.

Salazar-Soler, Carmen. 1987. El Tayta Muki y la Ukupacha. Prácticas y creencias religiosas de los mineros de Julcani, Huancavelica, Perú. Journal de la Société des américanistes 73 : 193-217.

Scott, James C. 1998. Seeing Like a State: How Certain Schemes to Improve the Human Condition Have Failed. New Haven: Yale University Press.

Stensrud, Astrid B. 2015. Raining in the Andes: Disrupted Seasonal and Hydrological Cycles. In Waterworlds: Anthropology in Fluid Environments, ed. Kirsten Hastrup and Frida Hastrup. New York: Berghahn Books.

- 2016. "It Seems Like a Lie": The Everyday Politics of World-Making in Contemporary Peru. In Critical Anthropological Engagements in Human Alterity and Difference, ed. Synnøve Bendixen and Bjørn E. Bertelsen. London: Palgrave Macmillan.

Taussig, Michael. 1980. The Devil and Commodity Fetishism in South America. Chapel Hill: University of North Carolina Press.

Valderrama, Ricardo, and Carmen Escalante. 1988. Del Tata Mallku a la Mama Pacha: Riego, sociedad y ritos en los andes peruanos. Lima: DESCO.

Zamalloa, Edgar Bravo. 2013. Reseña Histórica del Distrito de Majes. Lima: Corporación Grafical. 
Open Access This chapter is licensed under the terms of the Creative Commons Attribution 4.0 International License (http://creativecommons.org/licenses/ by $/ 4.0 /)$, which permits use, sharing, adaptation, distribution and reproduction in any medium or format, as long as you give appropriate credit to the original author(s) and the source, provide a link to the Creative Commons license and indicate if changes were made.

The images or other third party material in this chapter are included in the chapter's Creative Commons license, unless indicated otherwise in a credit line to the material. If material is not included in the chapter's Creative Commons license and your intended use is not permitted by statutory regulation or exceeds the permitted use, you will need to obtain permission directly from the copyright holder.

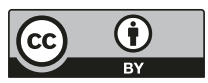




\title{
The Silent 'Cosmopolitics' of Artefacts: Spectral Extractivism, Ownership and 'Obedient' Things in Cañaris (Peru)
}

\author{
Juan Javier Rivera Andia
}

This chapter explores the terms by which an Amerindian group establishes its relationship with the land in a local context marked by extractivism and the forms in which this relationship emerges in the Peruvian Andes today. ${ }^{1}$

The practices of exacerbated extractivism-as they are currently lived and suffered in this part of the world (Bury 2005; De Echave 2011; Sotelo and Francke 2011) -rest on the presumption, both implicit and explicit, of a situation in which a 'natural' land-object lies inert and is, above all, susceptible to being used and appropriated according to human needs and aptitudes (or at least those of people whose resources and means grant them 'priority' over others). What happens, however, if the Amerindian forms, as often described by Andean ethnography, by which 'nature' is experienced and understood stops being interpreted as mere belief or superstition? What do the practices of extractivism in the Andes become if we take seriously the idea that the environment is 'living' to the point that it constitutes a subjectivity (or maybe even a person) with its own will and

J. J. Rivera Andía $(\bowtie)$

Universitat Autònoma de Barcelona, Barcelona, Spain

(C) The Author(s) 2019

165

C. Vindal Ødegaard, J. J. Rivera Andía (eds.), Indigenous Life

Projects and Extractivism, Approaches to Social Inequality and

Difference, https://doi.org/10.1007/978-3-319-93435-8_7 
with whom a relationship in 'social' terms is unavoidable? What happens if we distance ourselves from the narrative of Peruvian presidents who speak of the 'absurd, pantheistic ideologies' of the indigenas - those who usually emerge as part of the 'social' or 'socio-environmental conflicts' (Howe 2015; Handelsman 2002; Merino 2015; Ombudsman's Office 2014; Huamaní and Macassi 2011; Huamaní et al. 2012) that seem to be an ever-growing consequence of extractivism - and leave open the possibility, in the Andes, of what Cesarino calls 'an ontology of multiplicity that is radically distinct from western conceptions of private property and metaphysical monisms' (2016: 192)?

These are just some of the questions that have been addressed by anthropology in the most recent debates concerning extractivism and the Amerindian peoples of South America. What interests me here is the exploration of a possible hypothesis relating to one particular part of the problem: the indigenous regimes of land ownership in contemporary rural Andes. With that aim, I examine a specific ethnographic case based on my own fieldwork: the practices and conceptions relating to the access and control of the land in the area of Cañaris, a Quechua-speaking region in the Peruvian Northern Sierra (approximately at the intersection of the departments of Lambeyeque, Cajamarca and Piura) which is currently influenced by a huge open-pit mining project. From this study, a nonhuman entity emerges that is much less 'natural' and 'indigenous' than those usually proffered by anthropological studies dedicated to 'Cosmopolitics' (Stengers 1996); this entity could be called a 'Catholic temple'.

Finally, my questions throughout this chapter concerning the land reveal the need to initiate an ethnographic reflection on the relevance or usefulness of some key concepts in Andean anthropology (such as comunidad campesina or 'communal lands'), and the ways in which they have conventionally been understood.

\section{On the Treatment of Land Ownership and Certain Nonhuman Entities in Contemporary Andean Studies}

As space constraints do not permit a comprehensive survey of Andean studies related to land, mining, and comunidades campesinas (nor do I consider myself equipped to do so), I limit myself to making some brief references to one particular aspect of these studies: their more or less tacit 
agreement as to what constitutes the land in the indigenous Andes. That is, to use a term that is somewhat in vogue, to its 'ontology'.

The literature on the use of land in one of the main Andean indigenous organisations recognised by the Peruvian state, called comunidades campesinas (Diez 2012), is without a doubt plentiful (Urrutia 1992). Studies into the struggles over access to the land involving indigenous peoples are also copious, as much in the case of historical battles against estates and big landowners (Blanco 1972; Malpica 1984), as in the more recent confrontations with large multinational corporations (Salas Carreño 2008; Lanegra 2008; De Echave et al. 2009; Bebbington and Bebbington 2012; Bebbington and Bury 2014).

Among the different problems explored by both groups of studies (those dedicated to the daily or structural use of the land and those concerning the conflicts over access to or ownership of the land), one can usually find references to: negotiations over access to the land, the administration of its use (e.g., whether for livestock or for agriculture); accompanying ideological or ritual support structures (boundary demarcation rites, for instance, or issues concerning the distribution of water for irrigation purposes or pasture for grazing cattle); the legal status of the rights of indigenous peoples; the dynamics of indigenous social protest movements (or the ones in which indigenous people participate); and the speeches and 'performances' of activists, leaders or intellectuals involved in national politics or the public sphere.

Despite considerable differences between the above-mentioned studies, one can find common ground in both viewpoints concerning land in the Andes. This common ground can be found even in those approaches, which make significant attempts to get closer to indigenous perspectives. It is present even as concerns the understanding of an Andean 'logic' or 'rationality' (cf. Golte 1987 [1980]), whether in analyses of the 'kingdoms' or pre-Columbian political entities (Murra 2002) or in studies of comunidades campesinas (Fonseca Martel and Mayer 1988; Golte 1987 [1980]; Urrutia 1992). It goes without saying that those studies dealing with agrarian reforms or mining disputes in the Andes usually leave unproblematised a certain understanding of what constitutes the land. In fact, few of the studies mentioned above question the appositeness of the elemental terminology of their basic conceptual tools- that is, a specific relation between a subject (whether a human person or a mixed collective such as the 'ayllu' or the 'community') and an object (whether that be as a continuous extension of land or as a discontinuous whole divided into 
'ecologic floors'). Indeed, even in the intelligent proposal of Murra's 'vertical archipelago', there is not much hint of a debate on anything that might be considered more fundamental than an ideal of complementarity' enabling the control of a maximum number of ecologic 'floors'. This fundamental level that I refer to, in the case of the Amerindian Andes, is the existence (or not) of a relationship that can be considered similar or translatable to the 'ownership' of the land.

Recently, Salas Carreño proposed that 'humans must be understood as products of sustained relationships with places. Humans emerge as persons - in a material, as well as moral, sense-through this web of social interactions with named places' (2016: 833); 'the relations among humans and the places where they live are built upon exactly the same notions through which [Quechua] human social relations are constructed' (2016: 815). Although Salas Carreño does not make explicit the issue of ownership nor if what he means by 'places' would include things such as buildings_-but see the quick mention of a 'house' (2016: 828)—he highlights an important feature of Andean socio-natural worlds: 'places themselves ... emerge as intentional agents' (2016: 821) which are members of collectives entangling humans and nonhumans. The code, one could say, used with these agents is food; in fact, as the vast ethnography about this topic shows, food production, circulation and destruction are constantly used not only as part of good will offerings but also of straightforward threats (Rivera Andía 2000). In this chapter, I will expand this suggestion into places that are constructed by humans, while I specify the mode of human social relationship that emerges in the case of the land in the Cañaris area. In this specific relationship, feeding intervenes but in a reversed direction, as proposed by Salas Carreño (2016: 825-827), from places to humans.

As mentioned above, the questions that this chapter raises around the 'ownership' of land in an extractivist context permit the visibility of a nonhuman entity that has a tenuous relationship with the subject at hand: a Catholic temple called Iglisya.

The Cañaris Catholic temple, whilst a nonhuman entity attributed with agency, may appear, at least, slightly 'peculiar' in the general context of the nonhuman entities described by studies of indigenous cosmologies of the Andes.

This invisibility in the Andean ethnography of buildings such as the Iglisya, which have been erected and used by indigenous peoples for centuries, seems to stem from being both Catholic and constructed. On the one hand, the Iglisya is something that is an emblematic part of 
the 'Christian' cult, in contrast to the nostalgic reconstructions proposed by those studies in search of 'Andean thinking' as something opposed to (or hidden beneath) something that is imagined to be completely 'western' or 'modern'. An ethnography of a Christian temple would allow us to question the subtle persistence (sometimes countered, other times avoided) of that image of the native or indigenous (inherited from the romantic Indigenism of the first half of the twentieth century), in the contemporary anthropology of the Andes.

On the other hand, the Iglisya constitutes an entity that is clearly 'artificial'. That is, it consists of something that is obviously man made, in contrast to the ideal of the 'untouched' which usually awakens notions of the 'natural'. The Iglisya then differs from other entities, which are usually (more) directly connected to the earth and are considered to be a constituent part of the environment (for a remarkable exception, see Tomasi 2015). Past and current ethnographies of the Andes usually speak of the mountains - under the name of apus, awkillos, or wamanis - of the lakescalled encantos (Larco 2008) - of the water itself (cf. Stensrud, this volume) or even directly of entities that seem to completely overlap with 'nature', such as the Pachamama or Pachatierra (Gow and Condori 1976). I have alluded elsewhere (Rivera Andía 2015b) to the anthropological perspectives of Tim Ingold on mounds and buildings. It suffices here, therefore, to recall the problems associated with the distinction between that which is made by human hands and that which has grown in the environment: 'Do we not rather have to conclude of things made or built, as much as of things grown, that they are originating all the time' (Ingold 2013: 81)? It would be rather more useful to analyse the reasons behind the frequency or persistence of 'natural' (or nonartificial) features in the nonhuman entities highlighted by the studies regarding the cosmologies of the Andes.

The Iglisya, however, quite apart from being Christian and artificial, has a third characteristic that accentuates its outlandishness or peculiarity. This building is also a political entity to the extent to which it constitutes an alternative to one of the key assertions of extractivism concerning the ontology of land and the relationships extractivism establishes with it. The relationship with the land as a natural object is, silently but constantly, provoked by the spectre of extractivism in Cañaris: it could be said that the mining project and its governmental allies need that type of land (i.e., as natural object) to exist heedless of how troublesome its emergence might be (Blaser and de la Cadena 2017: 186). It is indeed this situation that converts a temple into a device for political intervention. How does the 
temple interfere, interrupt, or disturb the extractivist relationship with the land-object? As I show, the temple not only allocates and controls access to the land (which I refer to below as its administrative quality) but also emphasises those qualities of the relationship with the land that I would describe as those that sustain 'the living' or what Gan et al. call 'livability' (2017: G9). The Iglisya does so from two sides: by its generative or lifegiving dimensions (which I call the condensing aspect of the temple) and by its quality as a living entity dependent on human care (which I designate as its obedient quality).

Nevertheless, although it is involved in the local political game, the temple of Incahuasi remains invisible (Rivera Andía 2013, 2015b) or 'non-existent' (Escobar 2016) not only in the relationship between Cañarenses and La Minera (The Mining, as it is called by the people of Cañaris) but also in the subtle ethnographic explorations that try to distort or broaden the elements usually allowed within their scope (de la Cadena 2014; Schavelzon 2016: 118-119). Some of the causes of the scant visibility or existence of nonhuman entities, such as the Iglisya, can probably be linked to what I have pointed out: the temple is obviously artificial and explicitly Christian.

The political role of the Iglisya, moreover, involves neither its direct and explicit intervention nor overt demands on the public platforms that promote negotiations to resolve 'social conflicts' between the indigenous authorities in Cañaris and La Minera (or the government agencies that back it). In spite of its political importance, the participation of the Iglisya in these negotiations is neither invoked by the indigenous inhabitants of Cañaris nor authorised by their non-indigenous counterparts. Accordingly, the Iglisya does not enter into the public arena as part of a political discourse related to the ethical substance of indigeneity (as in the case described by Fabricant and Postero, this volume); nor is this building alluded to by political activists linked to international environmental networks (as is analysed by Li and Peñafiel, this volume). What remains of the political then in the emergence of this nonhuman entity?

In order to answer this question, the Iglisya requires us to make a rather serious conceptual revision of the terms in which one addresses these negotiations. Such is the intention of this chapter, which broaches an analysis of the Iglisya as a device for the ontological constitution of the land (one of the key elements of the social conflicts associated with mining in the Andes). Further definition may still be necessary. 
The force that drives this chapter is not entirely similar to the one behind those studies dedicated to indigenous conceptions of 'landscape', 'space', or 'places' (Pérez Galán 2004; Salvia 2014; Robin 2010; Rivera Andía 2005), where it is more or less accepted that an indigenous society is representing (and living in or with) the same ('natural') spaces differently. That is to say, this chapter does not require us to affirm or deny the existence of a world 'out there' that humans interpret or know in varying ways (according to their 'cultures', 'epistemologies', or 'intellectual frameworks'). It is enough to consider the Iglisya as 'a set of embodied skills and subjectivities ... a set of practices that array-and enact-a particular kind of person' (Law and Lien 2012: 4; see also Latour 2014a) and a particular kind of land. Without 'grounding the possibility of political difference in a prior story of how the world(s) must work' (Holbraad and Pedersen 2017: 54), the Iglisya as a child constitutes a type of land that is not fully encompassed, either by the mining operations' land or by the conservationists' land.

What I work to comprehend, instead, is a type of relationship with the land that implies a mutual constitution between it, humans (gathered together in this case in the comunidad campesina), and other nonhuman entities that, like the Iglisya, may or may not be part of the publicised negotiations around 'social conflicts' (Arellano-Yanguas 2011; Panfichi 2011; Tanaka 2012; Meléndez 2004). This emphasis on alternative ontologies of the human-land relationship (whether revealed in the public arena of social conflicts or not) is inspired by the contemporary debates around the 'systems of ownership' in the South American lowlands (Di Giminiani 2015; Brightman et al. 2016), some of which are, in turn, part of wider discussions around the dynamics of 'familiarisation' (Fausto 2012 [2001]), the composition of worlds (Descola 2014a), and the 'ontogenic' processes (Ingold in Descola and Ingold 2014) among indigenous groups.

\section{Extractivist Contingencies: A Spectre Haunts CaÑaris}

I have described in previous studies some of the distinctive characteristics of the indigenous group that inhabits the Cañaris area (Rivera Andía 2013, 2014a, 2015b; Rivera Andía et al. 2017) and the vicissitudes of the 'spectre of mining' in the mountains of the province of Ferreñafe (in the Peruvian department of Lambayeque) (Rivera Andía and Snowdon 2013). 
It is enough here to recall some aspects linked to the 'spectral' nature of the mining industry and the 'invisible' nature of the inhabitants of the Cañaris area. I start with this latter point. On the one hand, it could be said that the people of Cañaris have remained invisible, not only because of the usual subordination of modern-day indigenous constituent groups in the Peruvian public sphere but also because of the monopoly on 'indigeneity' that their southern counterparts (centred around an image of an 'imperial Cuzco') hold in the country's popular imagination. However, this 'invisibilisation' or 'actively produced non-existence' (Escobar 2016) has another aspect which, rather than being about pure negation, is more about disguise. In the same way that they are negated, the people of Cañaris are also affirmed. In serious circumstances, such as the brutal repression suffered during protests in 2013, they are treated as 'terrorists', a frequently used term in Peru's recent history (cf. González 2012). In situations of 'slow violence' (Nixon 2013), which is less dramatic but more persistent, the catch-all term used to label the existence of the people of Cañaris is 'poverty' (Eversole et al. 2005). In fact, one of the most frequent narratives recurring in the extractivist context in Cañaris is the description of the people of Cañaris as 'poor' (Rivera Andía 2014a). The label 'poverty' in the current national official discourse is used to describe living conditions characteristic of the predominant way of life in the Cañaris region and other parts of the Peruvian highlands, conditions which are usually considered indicative of need. In the context of the national and academic 'invisibility' that affects Cañaris, one of the ways in which its inhabitants have occasionally become more visible has been precisely through the label of poverty. Used as a form of stigma, this label is, above all, yet another way of continuing to ignore the rights of the Cañaris people as an indigenous group (De Echave et al. 2009; Merino 2012; Hallazi Méndez 2013; High 2015: 115, 179). The strategies by which the people of Cañaris criticise the external imposition of the label of poverty are dynamic and constantly changing. Nevertheless, these strategies are usually linked to some extent to religious practices, which have churches such as the Iglisya as their centre. In these cases, the ownership of land and agricultural work are reasserted as sources of wealth through renowned religious rituals in which only landowners may participate and where multiple expressions of life- and wealth-generative capacities of land unfold. In previous work, I have considered these as a collective, critical, and nonverbal reflection (Geertz 1973) of external attempts at stigmatisation (Rivera Andía 2014a). 
The 'ghostly extractivism' to which I refer relates to an open-pit mining project generically known as 'Cañariaco' that has been owned by the Canadian mining company Candente Copper since at least the first decade of this century (Candente Copper Corp 2011). Through my use of the term 'spectral extractivism', I hope to highlight the situation in which 'disaster would seem to start with the hopes and expectations that people entertain some time before, or independently of, the start of commercial oil extraction' (Weszkalnys 2016: 230). Nevertheless, ghostly extractivism differs from what other scholars have called 'the temporal politics of a disaster yet to come' in one key respect: The Cañaris area anticipation is much more tainted by anxiety and much less supplied with large-scale prevention devices than other cases shadowed by the 'resource curse' (Weszkalnys 2016: 228). The lack of anticipation is unfortunately also a function of the lack of information about mining operations that affects the Cañarenses.

In 2013, the first protest by the inhabitants of this region was brutally suppressed (La República 2013) when community members tried to block the access road to the mining camp (both of which are located on their lands) from which the explorations and measurements of the extractable minerals are carried out. To a certain extent, this was a protest against a spectre, against an entity of rather huge proportions, ambiguous, and tentacular, whose various components had for some time incessantly and drastically interfered in local politics, the economy, and landscape. This phantom-called, as mentioned above, La Minera-emerges fundamentally from the intersection of three factors: the international price of certain metals (in particular: gold, silver, and copper), the legal and illegal subterfuges of the organisations that benefit from the mineral extraction (Gudynas 2011, 2018), and, finally, the invisibility to which the greater part of the indigenous world of Cañaris is subjected.

Like all spectres, the presence of La Minera generates a considerable amount of 'anxiety' (Bessire 2014), likely due in part to La Minera's pursuit of the measureable, be it in the richness of the deposits or in the demarcation of the lands in which the mine will operate (just as Marc Brightman, this volume, points out in the Surinamese case). However, this anxiety is related likewise to the magnitude of the mining concessions made by the Peruvian government to La Minera, concessions that imply loss of land and contamination and scarcity of irrigation water (as Astrid Stensrud, this volume, describes regarding another Peruvian case), and 
have led to the physical destruction of the town, including the main square and the church (Silva Santisteban 2013). Indeed, the scope of the planned open-pit mine, processing plant, and deposits of tailings and waste rock leave little room for doubt about the radical changes to the environment and, consequently, the way of life for the people of Cañaris (as is the case in other parts of the world where sustainability is reduced to an oxymoron and development programme agents are transformed into collaborators; see Rajak 2011; Rajak and Gilberthorpe 2016; Connell and Howitt 1991).

Whatever their reaction to the spectre of La Minera, for the people of Cañaris, it brings the inevitability of transformation, drastic or gentle, of the land and rural life in the Cañaris area.

In addition to contrasting attitudes to the mining project among and within the comunidades campesinas of the Cañaris area, there are different degrees of unease according to how drastic the transformations are expected to be. I give three examples of adjoining comunidades campesinas in the area. At one extreme is the comunidad campesina of Cañaris, which has the camp for the mining project inside its communal lands: the tension here is at its highest. At the other extreme stands the comunidad campesina of Penachí, whose lands are not affected, so far, by the project: attitudes here border on indifference. The intermediate case can be illustrated by the comunidad campesina of Incahuasi: the road that has been built to access the mining camp passes very close by the principal town but is not within their boundaries. In short, the inhabitants of Incahuasi show both enthusiasm and fear but in a way that is neither as moderate as it is among the people of Penachí nor as pronounced as among the inhabitants of Cañaris.

To describe the established relationships with the land in the Cañaris area, I look to the case of Incahuasi, which is relatively nearby those who would be directly affected by La Minera: the members of the comunidad campesina of Cañaris. The reason for choosing Incahuasi is not only because it has most of the distinguishing characteristics of the Cañaris area nor that some of its organisations support the claims and protests against La Minera but is based on something more historically profound: Incahuasi is a direct product of the indigenous battle waged by those who are now its neighbours. The town was founded in 1747 by the 'Indians' of Penachí and Cañaris who built the Iglisya as an open act of defiance against the large-scale landowners who then controlled those lands. Its establishment was part of a series of actions carried out by the 'Indians' of 
Cañaris and Penachí to take over the land using all the legal methods at their disposal as well as some practices that were distinctly outside the law. Almost 300 years after its construction, their temple, the Iglisya, has finally become the principal nucleus of a political unit whose small towns and villages are today precisely those locations from which powerful others tried to gain control of the people of Cañaris.

There is, however, another even more crucial reason for us to centre our gaze on Incahuasi: the presence of a device constructed explicitly for such a struggle for the land. I am referring to an entity that is still somehow unusual in the context of Amerindian studies: a Catholic temple. Indeed, all the ethnographic and historical investigations (my own fieldwork included) into the control of land in the Cañaris area has led to this architectural complex. Its synchronic and diachronic analysis will help us understand not only the development but also the actual configuration of the relationships that humans establish with their lands in this region of the Andes.

\section{A Multiple Artefact: The Iglisra}

The few studies into religious buildings in Northern Peru have benefitted from various recent publications. ${ }^{2}$ Absent from these valuable contributions, however, is the place of a Catholic temple like the Iglisya in an environment where personhood reaches far beyond the world of the human (Rivera Andía 2008). Indeed, if in numerous Amerindian cases 'an object is nothing more than a subject that is incompletely understood' (Coelho de Souza 2016: 183), there arises the problem of how to understand objects which, like the adobe temple, have not only personhood but life.

The main issue at stake was the conceptualization of artefacts in a world in which the subject-object distinction is by definition fuzzy (and even inapplicable). What is the place of artefacts in a universe where personhood extends far beyond the human? (Brightman et al. 2016: 11)

I address this question in the following three discussions on the multiplicity of the church.

This extraordinary piece of architecture in the Cañaris area, the Iglisya, is an historical product of the indigenous struggle for the land throughout this entire region (Rivera Andía et al. 2017; Rivera Andía 2015a). Indeed, 
the building emerged out of the strategies of the indigenous people for the control and defence of their lands, constructed clandestinely in the middle of the eighteenth century during the final years of the viceroyalty of Peru (Huertas 1996). As such, the Iglisya is an historic milestone that crystallises indigenous control (to the detriment of the large-scale local landowners) of a set of lands that form the basis of what today is the comunidad campesina.

During my fieldwork (carried out between 2009 and 2013), at least three fundamental aspects of this building, the Iglisya, stood out: the administrative - expressed in its prerogatives over the distribution and control of land (Rivera Andía 2015b); the condensing-related to those aspects of it that are life-generating; and the obedient-related to the Amerindian perception of things as dependent or 'fully subjected' (Brightman et al. 2016: 12) (Fig. 7.1).

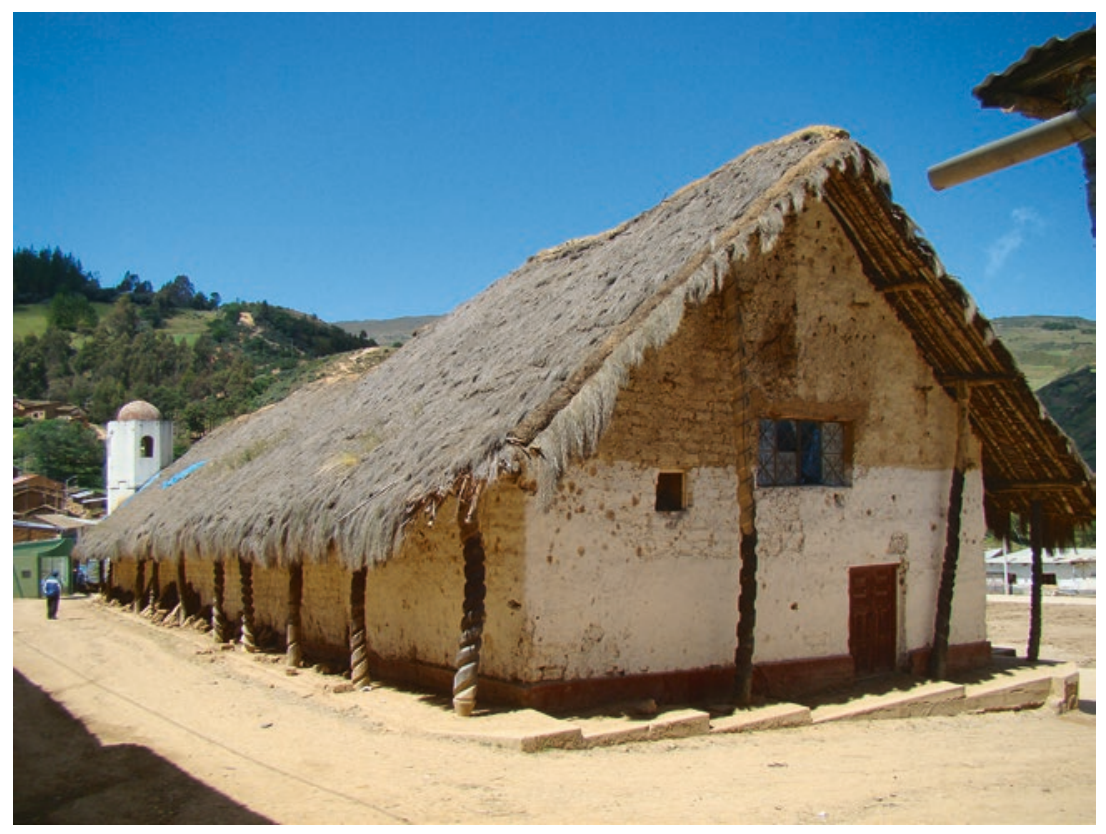

Fig. 7.1 The Iglisya of Incahuasi 


\section{An Iglisya-Land: Emergence and Functions of a Material Device}

The Iglisya functions as an administrative device in two respects. The first involves distribution. The thatched roof (made of jarava ichu) is divided into sections where ritual maintenance (carried out every five to ten years) is overseen by kinship groups (ayllus) or small villages that comprise the owners of the lands of Incahuasi. The distribution of the roof surface between these kinship groups is explicitly analogous to the distribution of the lands of Incahuasi between the same groups-and the division into two groups established by the ridge of the roof is analogous to the division established by the river that crosses the valley (Carrasco 2018).

The second aspect of this administration is expressed in the control of the access to land through the heads of kinship groups (cabezarios). ${ }^{3}$ The management of the Iglisya's main contents (namely, the Catholic statues) corresponds directly to the appropriation of the benefits derived from working the parcels of land corresponding to those statues. For example, only the kinship group of the cabezario charged with observing the ritual honours of Santa Rosa de Lima have access to the lands belonging to her and the products of those lands. Carrasco's (2014: 27-30) study of the Incahuasi contemporary archives confirms how the annual celebrations by the brotherhoods around the temple statues function as a legitimisation ritual (Rappaport 1999) of the ownership of the land. Today, more than half a century after the formal recognition of the indigenous community of Incahuasi by the Republic of Peru in 1963 - and, thereby, of their collective lands - community members continue to affirm that their lands 'belong' to the statues that live in the Iglisya (Vreeland 1993; Shaver 1992: 236).

Even if I were to end our considerations of the relationship between the temple and the land at this point, I could, perhaps, still affirm that this architectural object is actually a church land in the sense that it not only 'represents' the relationship that the inhabitants of the Cañaris area have with the land but embodies and constitutes that relationship (see Bloch 1998). On the one hand, the two sets of rituals performed in the Cañaris area (the fiestas patronales financed by the cabezarios and the collective renovation of the roof of the Iglisya) celebrate, legitimate, and constitute control over the land. On the other hand, the Iglisya, which serves as both the focal point and the refuge for the rituals, is the historical result of the struggle for that control over the land. Both types of exploration, the 
ethnographic and the historical, are strengthened by a common assertion over the mutual constitution (or ontological composition) of people and lands in the Cañaris area (Rivera Andía 2015b). The land as constituted by the Iglisya is not merely an historically disputed object (previously, between 'Indians' and landowners, nowadays, between farmers and mining companies). The land here is also part of a collective where it co-emerges (de la Cadena 2015: 102, 143; see also Canessa 2017: 549-550) with the people of Cañaris. In this way, the division of the lands and the kinship groups that tend them are mutually constituted through the rituals sheltered by the Iglisya and the material being of its own architecture. This mutual constitution can be thought of as a type of cartography in the sense that the church land not only represents but incessantly produces its surroundings in such a way that the boundaries between the different ontologies or resulting worlds are constantly realigning themselves (Blaser 2009: 16). In short, although I do not linger on this variant of 'ontological anthropology'-which tries to state something about what there actually is in the world (Holbraad and Pedersen 2017: 46-54) — it may be correct to assert that the temple is the relationship between humans and the land (Mol 1999; Blaser 2009; de la Cadena 2014). We could go so far as to say that the Iglisya (as an indigenous tool for the access to land ownership) could have a greater significance than the land itself: 'the weight appears to lie less in things ... and more on the conditions of the relationships by which knowledge becomes possible-less, therefore, on property, but more on the technologies or modes of transformation that allow access to the field of relationships' (Cesarino 2016: 202).

\section{An Alive and Generating-Life Iglisya}

In the second fundamental aspect of the temple, condensing, the Iglisya participates in the ritual and cosmological dynamic in Incahuasi, like an assemblage of the livability or life-giving properties attributed to the land—or, as Salas Carreño puts it, 'named places' (2016: 833). Through the statues that it houses and the altars that line its walls, the people of Incahuasi foster the fertility of their lands and the reproduction of the cattle that graze on those lands. The Iglisya condenses, in this way, the vitality of the land. Herein lies its living aspect: fertiliser or producer of life, the aspect that matters most in farming communities.

I am not going to linger here on the familiar topics of contemporary Andean indigenous ethnography—as, for instance, cattle branding rites 
(Rivera Andía 2003)—nor on the more recent perspectives on the components of living usually labelled 'anthropology of life' (Arnold 2017). However, I would like to highlight two tendencies: on the one hand, a definition of 'ontology' alludes to how a particular world is composedwhat its different components are-in accordance with the general disposition specified for each form of identification, as, for example, proposed by Philippe Descola (2014b: 437). An ontology, here, is based on something 'more elemental' (Descola 2014a: 239) than a cosmology. Rather, it is founded on 'systems of properties that humans ascribe to beings' (Descola 2006: 139), on 'generative patterns of inferences and actions, ways of composing the world and uses that follow analogous principles and that, for that reason, can be propagated in very similar forms and in very diverse historical contexts' (Descola 2014a: 112 and 236-237). In short, although Descola is conscious of the role played by 'historical contexts', the composition of a world is for him, above all, a matter of perception, of actualisation and of detection (or of omission) of the qualities of our environment and the relationships that are established in it (Descola in Descola and Ingold 2014: 30). On the other hand, some authors, such as Tim Ingold, have emphasised the procedural aspect of this notion of a world's composition, conceiving of it as 'a continuous process ... [a] perpetual development.... To compose a world is not to represent life as though it existed beforehand, but to make life emerge as it grows' (Ingold in Descola and Ingold 2014: 37-38, author's translation). My intention here is not to discuss the differences between two authors who are so complex and prolific. I content myself with highlighting two possible emphases of the so-called composition of the worlds: one which is considered a form of perception, actualisation, and detection of certain qualities and the other which is thought of more as a construction, a development, or a type of instigation for life to grow (Hallam and Ingold 2014). This contrast highlights a relationship between the emphasis on the development of those elements that compose a world and the emphasis on the 'living' aspects that they have. Both facets seem to be underlined by the relationship between the people and the land in the Cañaris area: the Iglisya is not just an historically constituted device but also a 'living' component of the world. This process of mutual constitution recalls what Ingold has called-in his critique of the concept of ontology-an 'ontogeny' (ontogénie) in his emphasis on the inevitable temporality of continuous human evolution (Ingold in Descola and Ingold 2014: 37). The relevance of the study of 'temporalities' in the study of the systems of land 
ownership in South America has been highlighted by Viegas (2016: 252): ' $[\mathrm{T}]$ emporalities should be considered a key perspective in the understanding of the lived experience of possession, namely in the history of entanglements in the possession of land.' I now move on to discuss the third fundamental aspect of the Iglisya, the obedient. To my knowledge, this aspect has not been addressed previously in Andean ethnographies of indigenous buildings or artefacts.

\section{A Church-Child: On Obedient Entities in the Andes}

This third fundamental aspect of the Iglisya becomes evident when the building is, symbolically and tacitly as well as concretely and explicitly, conceived of and treated as an obedient entity. During the periodic renovation of its roof-through a ritual called Iglisya qatay, which has been far less documented by ethnography than, for example, the roofing rituals of newly built family houses (Gose 1991) - the temple is treated like a child and is given a ritual haircutting ( rutu chikuy, or as it is called locally, landa) (Rivera Andía 2015b). Indeed, the Iglisya qatay follows the same sequence as the well-known pre-Columbian ritual still found throughout the Andes during which a child has its first haircut in exchange for ribbon tassels and donations, progressively integrating the infant into the human world. During the Iglisya qatay, the roof of the church is treated in the same way as a child's hair during the landa ceremony; both rituals have the same protagonists, songs, elements, and sequences (Rivera Andía 2015b). The building appears, then, not just as a living being but more specifically as a human child. More precisely still, it is treated as a certain kind of child: one that is being put through the first phases of its gradual incorporation into the society of upright and honest humans (runa), in the way that this is understood in the Andes (Ortiz Rescaniere 1999).

Let's return to the above-mentioned feeding relationship between (Quechua) humans and places in the Peruvian Southern Andes. As we have seen, among the Cañarenses or Quechua of Cañaris, humans treat their lands as do their children. If this is a correct interpretation, then the anomaly that Salas Carreño could not help but detect in Cuzco would be resolved. He observes that ' $[\mathrm{t}]$ he relations between human parents and their children are slightly different from those between places and humans. While children do not feed their human parents, humans must continually feed places' (Salas Carreño 2016: 828). What happens then when humans leave the role of the child who is nurtured by the land and take instead the 
role of those who nurture the land as one would a child? I suggest that this view allows us to explain the apparent incongruity of the statement above: the land is fed by humans because they are meant to do so, as they do with their children. This is, of course, a case in which humans are not permanently obliged to respect or fear powerful nonhumans. In this regard, the Cañaris ethnography and other examples (Rivera Andía 2000) recant the 'strong hierarchical relationship, with humans dependent on the places' goodwill' depicted in Cuzco (Salas Carreño 2016: 829). The Iglisya shows that a place (if not the land as well) can certainly be dependent on human goodwill. Therefore, rather than a 'strong asymmetry of power', in the case of land ownership in Cañaris, I see a symmetric confrontation or fight between humans and nonhumans. ${ }^{4}$

This ritual treatment of the Iglisya as a child establishes a close relationship between the control of the land and the 'nurturing' values and practices of the people of Cañaris. In this way, it personifies an indigenous form of conceiving of and putting into practice the ownership, not just of buildings but, above all, of the land. This analogy between childhood and the device for control of the land that is the Iglisya suggests a central role in the exercising of ownership and of care and nurture, whether it be of nonhuman entities or of human beings as children: 'care and nurture play a central role in the ownership of places' (Brightman et al. 2016: 24). The relevance for this Andean case, as well as of the perspectives of the authors gathered in this collection dedicated to 'ownership' and 'nurture' in the Amazon, will become ever more evident from this point on.

What I wish to highlight in this chapter are the logical consequences of this analogy between the Iglisya-land and human childhood: both are treated and understood as being under the care of human kinship groups that comprise the comunidad campesina:

\begin{abstract}
[A]ppropriating and nurturing acts of "domestication" are often necessary to maintain their [the object's] status... As Erikson (2009: 188) suggests, in Amazonia "things", rather than being conceived as independent subjects, seem to be considered as semi-autonomous subordinates. In other words, "things" seem to be less perceived as full subjects than as fully subjected ... submitted to an "overt life" of dependency as "obedient things" in much the same way as children, captives, clients and pets are. (Brightman et al. 2016: 12)
\end{abstract}

The ritual treatment of the Iglisya as a child implies that it is not a complete subject as such but rather a subordinate or dependent entity. Therefore, there is more than a building (made for and by the 'Indians') as 
a milestone in the historical process of the constitution of their actual communal lands. Additionally, the 'creativity' exalted in its clandestine foundation and unusual architecture seems to be closely connected to a process of care or 'familiarisation' of these lands:

The ownership of nonbuman persons is part of the process of place-making. Creativity begets ownership, and the making of artefacts may create new persons ... who may be in turn become owners themselves. Such processes of creative appropriation are ... very close to the familiarizing processes of nurture. (Brightman et al. 2016: 11)

The comparative possibilities between 'Andean' and 'Amazonian' cases are obviously outside the remit of this chapter. Leaving such a theme for future studies, I return here to our ethnographic case from the Peruvian Sierra in order to concentrate on its own specific characteristics. In sum, two findings (one hierarchical association and another symmetrical one) allow us to develop a hypothesis concerning the type of relationship that humans establish with the land in the Cañaris area. A hierarchical relationship, as noted above, is established between humans and the Iglisya, which places it in the category of obedient entities identified in the ethnography of the South American lowlands with children, captives, clients, or pets. What appears to emerge here, then, is the configuration of an Iglisya-child.

There is a symmetrical relationship, as established above, between the Iglisya and the land. Whether the Iglisya is an historical product of the land or an ethnographic artefact for the distribution and control of it, this relationship calls attention to the emergence of an Iglisya-land. It is worth remembering, in passing, that the building in question is literally constructed of two things extracted from the land: earth (the principal material of the sun-dried adobe bricks that form its walls) and the plants that grow on the thatched roof (Carrasco et al. 2016).

The hypothesis then, is as follows: if the relationship that humans have with the land materialises in the Iglisya (or is represented by it, or simply is it), and if the Iglisya is treated as and conceived of as an obedient entity, is the relationship between these people and this land then analogous to the one that they have with children? Is the land here included among the still not completely human entities, which need to be fed and cared for? Is the relationship that the people have with the land understood and staged in the terms used to care for an obedient subject that is in the process (always incomplete) of becoming human? 


\section{Final Considerations}

This chapter offers an ethnography that seeks to overcome the invisibility and asymmetry to which indigenous groups such as the Cañarenses have historically been subjected and to provide an empirical basis for an argument about mining's role in the reproduction of social and environmental inequality in the Andes. This is particularly the case nowadays as increasing numbers of mining corporations' projects threaten ways of life-while state agencies simultaneously commoditise an essentialised culture of the area (as is currently being done [cf. Martínez 2017]). The simultaneity of these processes should not be surprising if we remember that both ' $[S]$ tate agencies and mining corporations are usually much better positioned to commission and direct ethnographic research or to exploit ethnographic knowledge' (Ballard and Banks 2003: 306).

In the Cañaris area, collectives are extended to include not only runas and santospatrones and places like the mountains and the lakes (as described by Andean ethnography and by both Ødegaard and Stensrud, this volume; see also Salas Carreño 2016) but also other nonhuman entities that have been historically constituted by humans, like the Iglisya. Its relevance emerges from what Latour considers 'the crucial political task': 'to distribute agency as far and in as differentiated a way as possible' (Latour 2014a: 15). Although rather different from a 'sacred' entity that must be 'respected' (Cepek 2016) and is part of or identifies itself with 'nature', the significance of this indigenous artefact for the Cañarenses largely exceeds the categories of 'religion', 'culture', or 'patrimony'. Far from presupposing any kind of 'non-modern ontological bases' (Schavelzon 2016: 132), the Iglisya's existence stands only on 'relational contrasts produced in acts of comparing one set of purported commonalities with another' (Salmond in Boellstorff 2016: 402). But even if considered as nothing more than a mining-activated provisional 'quasi-object' (Cepek 2016), the politics of the Iglisya (and of the relationships it embodies) is as crucial as that which involves the historic struggle for control of the land. At the same time, the Iglisya is an entity under human care, as is the land itself. Both are interwoven in many ways: the land provides the raw materials used to build the Iglisya; the Iglisya, in turn, distributes, organises, and periodically produces the land. Both Iglisya and land constitute the de facto Cañaris collective. How do we make 'operational' or recognisable, de jure, the 'Cosmopolitic' (Stengers 1996; see also Blaser and de la Cadena 2017:186; Schavelzon 2016: 123) of this collective in the face of 
the real-existing post-neoliberal regime that imbues the Cañaris area (Arsel et al. 2016; Bury 2005)? Is it appropriate to revisit the omnipresent denomination comunidad campesina when it comes to recognising the politically and economically relevant groups in this region of the world, which has been profoundly saturated with resource extraction? What then would constitute 'communal lands' in a situation where the land is part of a relationship such as that embodied by the Iglisya? How would our ethnographic understanding of the comunidad campesina be affected if ownership of the land were based on such radically different principles and if the exclusively human collectives were not those relevant in the political sphere? Is it possible, finally, to make the legal aspect of this relationship operational in the national sphere, above all in a situation such as the current one, marked by the struggles that have arisen as a result of the Latin American 'extractivist imperative' (Arsel et al. 2016)?

If the hypothesis that I am formulating holds, then yet another threat could be added to the already long list associated with spectral extractivism in the Cañaris area. I am referring to the suppression of a specific form of relationship that, until now, would have been crucial for the existence of the community of humans and nonhumans such as the one found in this part of the Andes. To threaten this relationship would be to eliminate a group, a world, and a way of life that specifically and probably precedes (Brightman et al. 2016: 3) those trying to replace it.

In the case that concerns us here, that of architecture and ownership of the land, La Minera also plays a role analogous to that of those external agents who are either trying to demolish the Iglisya in order to build a church of concrete (the mayors with their life-projects focused on the urban Spanish-speaking world on the north coast of Peru) or to neglect it until it falls into a ruin (the members of the religious groups created by the Summer Institute of Linguistics).

In a situation as persistently intimidating as this one, it seems difficult to envisage the relationships that are materialised in the Iglisya as a 'threat' to modernity - in the sense that Mario Blaser (2009) uses this term when describing the $Y r m o$ of the Yshiro in Paraguay-or as a predatory aspect of the alternative world the Iglisya constitutes (Brightman et al. 2016: 3). Indeed, the practices materialised by the Iglisya and the ones corresponding to spectral extractivism might be rather 'kept in a field of equivocations because they do not severely interrupt each other or irremediably disrupt the commoning work' (Blaser and de la Cadena 2017: 190). I would, therefore, be content to glimpse in the Iglisya a 
fighting implement (always available although not continuously used) in the 'war' of worlds that some authors have recently described (Latour 2009, 2014a: 5, b, 2015; Viveiros de Castro 1999, 2015a, b; Schavelzon 2016: 126). The relevance of the Iglisya as a device in the struggle for the land certainly relies does not rely on its visibility neither in the public sphere nor scholarly literature-where earth-beings are usually described in terms of respect or resistance (cf. Merino 2015: 86; Rénique 2009). It does not figure in public speeches nor is it invoked by activists involved in resistance against La Minera (which increasingly receives public attention in the forms described by $\mathrm{Li}$ and Paredes Peñafiel, this volume). Nor do we find southern earth-beings as apus-also described by Stensrud and Ødegaard, this volume-invoked explicitly in indigenous organised protests. It is possible, however, that the prevalence of the material, collective, and nonverbal aspects of the relationships woven into the Iglisya can be considered as part of 'a cosmopolitical economy of persons both human and nonhuman' (Brightman et al. 2016: 24) that might configure a 'Cosmopolitics' (Stengers 1996) if our current conceptualisations about "whom, precisely, is one "taking seriously"' and "how "other" the otherwise can be' (Candea 2014) are expanded.

Finally, we should perhaps remember the relevance of an 'ontography' (Holbraad 2009, 2014, 2017) compromised by the description of those worlds that interrupt 'the one-world story' (Escobar 2016: 22). If anything were to suggest itself as salvageable from the rivers of ink that have unleashed the current discussions about the 'ontological turn', perhaps it would be the obsessive methodological emphasis on the 'reflectivity' of our own concepts around ethnographic contingencies (Holbraad and Pedersen 2017). Through this chapter, I hope to contribute to the accompaniment of just such a conceptual reflectivity with its preoccupation for the frictions, inequalities, and hierarchies that make the world of Cañaris something 'actively produced as non-existent' (Escobar 2016: 15).

Acknowledgements The author would like to thank Margaux Majewska, Marieka Sax, Cecilie Vindal Ødegaard, Marc Brightman and Katharine Wheeler for their critical readings and constructive suggestions for revisions of the initial manuscript. I also wish to thank the Marie Curie Alumni Association (MCAA) for its support during the writing of this chapter. A good deal of the motivation to write this chapter comes from the huge and wide-ranging impacts mining has had in both my personal history and that of my family, natives of the Peruvian Central highlands and workers of some the many sections of Centromín Peru surrounding La Oroya refinery and Cerro de Pasco open pit mine. 


\section{Notes}

1. For a definition of extractivism, see the Introduction by Rivera Andía and $\varnothing$ degaard, this volume.

2. I have reviewed (Rivera Andía 2016) and listed (Rivera Andía 2014b) these publications previously.

3 . The relationship between land (claims), residence, and ties to locality and to kin have been studied in the Andes (Salas Carreño 2016) and elsewhere (Ballard 1997; Jorgensen 2010): 'land condenses a host of social relationships for which territory serves as a form of shorthand reference' (Ballard and Banks 2003: 300).

4. Although the case discussed here deals with the struggle for land ownership, I have previously described other situations in which ownership of other things (such as cattle) is disputed in indigenous terms (Rivera Andía 2003).

\section{REFERENCES}

Arellano-Yanguas, Javier. 2011. ¿Minería sin fronteras? Conflicto y desarrollo en regions mineras del Perú. Lima: IEP, PUCP.

Arnold, Denise. 2017. Hacia una antropología de la vida en los Andes. In El desarrollo y lo sagrado en los Andes. Resignificaciones, interpretaciones y propuestas en la cosmo-praxis, ed. Heydi Galarza. La Paz: ISEAT.

Arsel, Murat, Barbara Hogenboom, and Lorenzo Pellegrini. 2016. The Extractive Imperative in Latin America. The Extractive Industries and Society 3 (4): 880-887.

Ballard, Chris. 1997. It's the Land, Stupid! The Moral Economy of Resource Ownership in Papua New Guinea. In The Governance of Common Property in the Pacific Region, ed. Peter Larmour. Canberra: Australian National University.

Ballard, Chris, and Glenn Banks. 2003. Resource Wars: The Anthropology of Mining. Annual Review of Anthropology 32: 287-313.

Bebbington, Anthony, and Denise Bebbington. 2012. Post-What? Extractive Industries, Narratives of Development and Socio-Environmental Disputes Across the (Ostensibly Changing) Andean Region. In New Political Spaces in Latin American Natural Resource Governance, ed. H. Haarstad. London: Palgrave Macmillan.

Bebbington, Anthony, and Jeffrey Bury, eds. 2014. Subterranean Struggles. New Dynamics of Mining, Oil, and Gas in Latin America. Austin: University of Texas Press.

Bessire, Lucas. 2014. Behold the Black Caiman: A Chronicle of Ayoreo Life. Chicago: University of Chicago Press.

Blanco, Hugo. 1972. Tierra o muerte. Mexico City: Siglo XXI.

Blaser, Mario. 2009. The Threat of the Yrmo: The Political Ontology of a Sustainable Hunting Program. American Anthropologist 111 (1): 10-20. 
Blaser, Mario, and Marisol de la Cadena. 2017. The Uncommons: An Introduction. Anthropologica 59: 185-193.

Bloch, Maurice. 1998. The Resurrection of the House Amongst the Zafimaniry of Madagascar. In How We Think They Think, ed. Maurice Bloch. Boulder: Westview Press.

Boellstorff, Tom. 2016. For Whom the Ontology Turns. Theorizing the Digital Real. Current Anthropology 57 (4): 387-407.

Brightman, Marc, Carlos Fausto, and Vanessa Grotti. 2016. Introduction. In Ownership and Nurture. Studies in Native Amazonian Property Relations, ed. Marc Brightman, Carlos Fausto, and Vanessa Grotti. New York: Berghahn Books.

Bury, Jeffery. 2005. Mining Mountains: Neoliberalism, Land Tenure, Livelihoods, and the New Peruvian Mining Industry in Cajamarca. Environment and Planning A: Economy and Space 37: 221-239.

Candea, Matei. 2014. The Ontology of the Political Turn. Cultural Anthropology. https://culanth.org/fieldsights/469-the-ontology-of-the-political-turn. Accessed 18 Jan 2018.

Candente Copper Corp. 2011. Cañariaco Norte Copper Project Pre-feasibility Study Progress Report. http://www.candentecopper.com/i/pdf/CanariacoPFS.pdf. Accessed 19 Mar 2016.

Canessa, Andrew. 2017. Bearing Witness. Testimonies, Translations, and Ontologies in the Andes. HAU: Journal of Anthropological Theory 7 (1): $545-551$.

Carrasco, Alfredo. 2014. Inkawasi, la singularidad de sus expresiones culturales. Ferreñafe: CIDEC.

- 2018. Instrumentos musicales y danzas en Incahuasi. In Cañaris. Etnografías y documentos de la sierra de Lambayeque (Perú), ed. Juan Javier Rivera Andía. Buenos Aires: Colección Ethnographica, Rumbo Sur.

Carrasco, Alfredo, Julio Fernández, and Karina Villarroel. 2016. Iglisya qatay. El fervor popular en incahuasi. Chiclayo: Ministerio de Cultura.

Carrasco, Alfredo. 2018. Instrumentos musicales y danzas en Incahuasi. In Cañaris. Etnografías y documentos de la sierra de Lambayeque (Perú), ed. Juan Javier Rivera Andía. Buenos Aires: Colección Ethnographica, Rumbo Sur.

Cepek, Michael. 2016. There Might Be Blood: Oil, Humility, and the Cosmopolitics of a Cofán Petro-Being. American Ethnologist 43 (4): 623-635.

Cesarino, Pedro de Niemeyer. 2016. Doubles and Owners: Relations of Knowledge, Property and Authorship Among the Marubo. In Ownership and Nurture. Studies in Native Amazonian Property Relations, ed. M. Brightman, C. Fausto, and V. Grotti. New York: Berghahn Books.

Coelho de Souza, Marcela. 2016. The Forgotten Pattern and the Stolen Design: Contract, Exchange and Creativity Among the Kisêdjê. In Ownership and Nurture. Studies in Native Amazonian Property Relations, ed. M. Brightman, C. Fausto, and V. Grotti. New York: Berghahn Books. 
Connell, John, and Richard Howitt, eds. 1991. Mining and Indigenous Peoples in Australasia. Sydney: Sydney University Press.

De Echave, José. 2011. La minería peruana y los escenarios de transición. In Transiciones Postextractivismo y alternativas al extractivismo en el Perú, ed. Alejandra Alayza and Eduardo Gudynas. Lima: CEPES, RedGE.

De Echave, José, Alejandro Diez Hurtado, Ludwig Huber, Bruno Revesz, Xavier Ricard Lanata, and Martín Tanaka. 2009. Minería y conflicto social. Lima: IEP, CIPCA, CBC.

de la Cadena, Marisol. 2014. The Politics of Modern Politics Meets Ethnographies of Excess Through Ontological Openings. Theorizing the Contemporary. http://www.culanth.org/fieldsights /471-the-politics-of-modern-politicsmeets-ethnographies-of-excess-through-ontological-openings. Accessed 19 Mar 2016.

- 2015. Earth Beings. Ecologies of Practice Across Andean Worlds. Durham: Duke University Press.

Descola, Philippe. 2006 (2005). Beyond Nature and Culture, Radcliffe-Brown Lecture in Social Anthropology, 2005. Proceedings of the British Academy 139: $137-155$.

- 2014a. La composition des mondes. Entretiens avec pierre charbonnier. Paris: Flammarion.

- 2014b. The Difficult Art of Composing Worlds (and of Replying to Objections). Journal of Ethnographic Theory 4 (3): 431-443.

Descola, Philippe, and Tim Ingold. 2014. Etre au monde. Quelle expérience commune? Lyon: Presses Universitaires De Lyon.

Diez, Alejandro. 2012. Tensiones y transformaciones en comunidades campesinas. Lima: CISEPA, PUCP.

Di Giminiani, Piergiorgio. 2015. The Becoming of Ancestral Land: Place and Property in Mapuche Land Claims. American Ethnologist 42 (3): 490-503.

Escobar, Arturo. 2016. Sentipensar con la Tierra: Las Luchas Territoriales y la Dimensión Ontológica de las Epistemologías del Sur. AIBR, Revista de Antropología Iberoamericana 11 (01): 11-32.

Erikson, P. 2009. Obdient Things: Reflections on the Matis Theory of Materiality. In The Occult Life of Things: Native Amazonian Theories of Materiality and Personhood, ed. F. Santos-Granero, 173-190. Tucson: University of Arizona Press.

Eversole, R., John Mcneish, and A.Y. Cimadamore, eds. 2005. Indigenous Peoples and Poverty. An International Perspective. London/New York: Crop.

Fausto, Carlos. 2012 [2001]. Warfare and Shamanism in Amazonia. Cambridge: Cambridge University Press.

Fonseca Martel, César, and Enrique Mayer. 1988. Comunidad y producción en la agricultura andina. Lima: Fomciencias.

Gan, Elaine, Anne Tsing, Heather Swason, and Nils Bubandt. 2017. Introduction. Haunted Landscapes of the Anthropocene. In Arts of Living on a Damaged 
Planet, ed. A. Tsing, H. Swanson, E. Gan, and N. Bubandt. Minneapolis/ London: University of Minnesota Press.

Geertz, Clifford. 1973. Notes on the Balinese Cockfight. In The Interpretation of Cultures, ed. C. Geertz. New York: Basic Books.

Golte, Jürgen. 1987 [1980]. La racionalidad de la organización andina. Lima: IEP.

González, Eduardo. 2012. Sus muertos y los nuestros. https://latorredemarfil. lamula.pe/2012/05/30/sus-muertos-y-los-nuestros/eduardogonzalez/. Accessed 15 Feb 2018.

Gose, Peter. 1991. House Rethatching in an Andean Annual Cycle: Practice, Meaning and Contradiction. American Ethnologist 18 (1): 39-66.

Gow, Rosalind, and Bernabe Condori. 1976. Kay Pacha. Cuzco: Centro de Estudios Rurales Andinos.

Gudynas, Eduardo. 2011. Debates sobre el desarrollo y sus alternativas en América Latina: una breve guía heterodoxa. In Más allá del dessarollo. Quito: Abya Yala y Fundación Rosa Luxemburg.

- 2018. Extractivismos y corrupción en América del Sur. Estructuras, dinámicas y tendencias en una íntima relación. Revista de Ciencias Sociales y Humanas 10 (10): 73-87.

Hallam, Elizabeth, and Tim Ingold, eds. 2014. Making and Growing. Anthropological Studies of Organisms and Artefacts. Farnham: Ashgate.

Hallazi Méndez, Luis. 2013. Perú: el caso de la comunidad de cañaris y el derecho a la consulta previa. http://servindi.org/actualidad/81367. Accessed 13 Dec 2013.

Handelsman, Simon D. 2002. Human Rights in the Minerals Industry. MMSD Work. Paper No. 9. http://pubs.iied.org/pdfs/G00531.pdf. Accessed 26 Feb 2018.

High, Casey. 2015. Victims and Warriors. Violence, History and Memory in Amazonia. Champaign: University of Illinois Press.

Holbraad, Martin. 2009. Ontology, Ethnography, Archaeology: An Afterword on the Ontography of Thing. Cambridge Archaeological Journal 19 (3): 431-441. 2014. Tres Provocaciones Ontológicas. Ankulegi 18: 127-139.

. 2017. The Contingency of Concepts: Transcendental Deduction and Ethnographic Expression in Anthropological Thinking. In Comparative Metaphysics. Ontology After Anthropology, ed. P. Charbonnier, G. Salmon, and P. Skafish. London/New York: Rowman and Littlefield.

Holbraad, Martin, and Morten Axel Pedersen. 2017. The Ontological Turn. An Anthropological Exposition. Cambridge: Cambridge University Press.

Howe, Cymene. 2015. Latin America in the Anthropocene: Energy Transitions and Climate Change Mitigations. The Journal of Latin American and Caribbean Anthropology 20 (2): 231-241.

Huamaní, Giselle, and Sandro Macassi. 2011. Gestión de conflictos socio ambientales. Lima: Consorcio de Investigación Económica y Social. 
Huamaní, Giselle, Sandro Macassi, Julio Alegría, and Telmo Rojas. 2012. Hacia una major gestión de los conflictos socio ambientales en el Perú. Lima: Consorcio de Investigación Económica y Social.

Huertas, Lorenzo. 1996. Patrones de asentamiento poblacional en piura (1532-1850). Bulletin de l'Institut Français d'Etudes Andines 25 (1): 91-124.

Ingold, Tim. 2013. Making: Anthropology, Archaeology, Art and Architecture. London: Routledge.

Jorgensen, Dan. 2010. Who and What Is a Landowner? Mythology and Marking the Ground in a Papua New Guinea Mining Project. Anthropological Forum 7 (4): 599-627.

La República. 2013. Enfrentamiento por proyecto Cañariaco dejó dos heridos graves. http://larepublica.pe/politica/688546-enfrentamiento-por-proyectocanariaco-dejo-dos-heridos-graves. Accessed 26 Jan 2013.

Lanegra, Iván. 2008. El (ausente) estado ambiental. Razones para la reforma de las instituciones y las organizaciones públicas ambientales en el Perú. Lima: Realidades.

Larco, Laura. 2008. Más allá de los encantos: Documentos históricos y etnografía contemporánea sobre extirpación de idolatrías en Trujillo (siglos XVIII-XX). Lima: l'Institut Français d'Etudes Andines.

Latour, Bruno. 2009. Perspectivism: 'Type' or 'Bomb'? Anthropology Today 25 (2): $1-2$.

. 2014a. Agency at the Time of the Anthropocene. New Literary History 45: $1-18$.

- 2014b. Another Way to Compose the Common World. HAU: Journal of Ethnographic Theory 4 (1): 301-307.

- 2015. Los Modernos, Según la Antropología, N. Revista de Cultura (Clarín). http://www.revistaenie.clarin.com/ideas/Bruno-Latour-modernosantropologia_0_1295270475.html. Accessed 19 Mar 2016.

Law, John, and Marianne E. Lien. 2012. Denaturalising Nature. Public Inaugural Sawyer Seminar Talk at University of California, Davis. https://www.sv.uio. no/sai/english/research/projects/newcomers/publications/working-papersweb/denanturalisingnaturetalk2.pdf. Accessed 19 Jan 2018.

Malpica, Carlos. 1984. Los dueños del Perú. Lima: Peisa.

Martínez, Luz. 2017. Música y cantos de Incahuasi. Lima: Ministerio de Cultura.

Meléndez, Carlos. 2004. Hipótesis sobre los conflictos en el Perú actual. Secuelas y lecciones de los años de violencia política. Lima: Asociación Civil Transparencia.

Merino, Roger. 2012. Perú: en defensa de lo comunal: cinco errores en el análisis de los conflictos socio-ambientales. http://servindi.org/actualidad/65708. Accessed 13 Dec 2013.

- 2015. The Politics of Extractive Governance: Indigenous Peoples and Socio-Environmental Conflicts. The Extractive Industries and Society 2: 85-92.

Mol, Annemarie. 1999. Ontological Politics. A Word and Some Questions. The Sociological Review 47 (S1): 74-89. 
Murra, John V. 2002. El mundo andino: población, medio ambiente y economía. Lima: Pontificia Universidad Católica del Perú e Instituto de Estudios Peruanos. Nixon, Rob. 2013. Slow Violence and the Environmentalism of the Poor. Cambridge, MA: Harvard University Press.

Ombudsman's Office. 2014. Reporte de Conflictos Sociales. Lima: Defensoría del Pueblo.

Ortiz Rescaniere, Alejandro. 1999. El Individuo Andino, Autóctono y Cosmopolita. In Cultura y globalización, ed. Carlos Iván Degregori and Gonzalo Portocarrero. Lima: PUCP, Universidad del Pacífico, IEP.

Panfichi, Aldo. 2011. Contentious Representation and Its Impact in Contemporary Peru. In Fractured Politics: Peruvian Democracy Past and Present, ed. J. Crabtree. London: University of London Press.

Pérez Galán, Beatriz. 2004. 'Somos como incas'. Autoridades tradicionales en los Andes peruanos, Cuzco. Madrid: Iberoamericana.

Rajak, Dinah. 2011. Theatres of Virtue: Collaboration, Consensus and the Social Life of Corporate Social Responsibility. Focaal 60: 9-20.

Rajak, Dinah, and Emma Gilberthorpe. 2016. The Anthropology of Extraction: Critical Perspectives on the Resource Curse. Journal of Development Studies 53 (2): 186-204.

Rappaport, Roy. 1999. Ritual and Religion in the Making of Humanity. Cambridge: Cambridge University Press.

Rénique, Gerardo. 2009. Law of the Jungle in Peru: Indigenous Amazonian Uprising Against Neoliberalism. Socialism and Democracy 23 (3): 117-135.

Rivera Andía, Juan Javier. 2000. Los gentiles de Llampa. Anthropologica 18: 271-280.

-2003. La fiesta del Ganado en el Valle del Chancay. Lima: PUCP.

- 2005. Territorio e identidad en los Andes. Concepciones populares en torno a las zonas ecológicas altas en la sierra de Lima. Revista de Dialectología $y$ Tradiciones Populares 40 (2): 55-76.

-2008. Apuntes sobre la alteridad constituyente en los Andes. Ambivalencias rituales y lingüísticas sobre un espacio imaginario. Revista española de antropología americana 38 (1): 191-215.

- 2013. Un Patrimonio cultural ignorado y en riesgo en los Andes septentrionales del Perú. Apuntes etnográficos sobre dos instrumentos musicales endémicos de la sierra de Lambayeque. In Wege im Garten der Ethnologie. Zwischen dort und hier. Festschrift für Maria Susana Cipolletti (Collectanea Instituti Anthropos, 46), eds. Hanna Heinrich and Harald Grauer. Sankt Augustin: Anthropos Institut.

- 2014a. Fears and Rituals in Contemporary Peruvian Andes. In The Anthropology of Fear. Cultures Beyond Emotions, ed. A. Boscoboinik and H. Horáková. Berlin: LIT Verlag.

— 2014b. Fuentes para el estudio de una región 'invisible' de los Andes Peruanos: Contribución para una bibliografía exhaustiva sobre la sociedad y la 
naturaleza en la sierra de Lambayeque, Perú. Anuario Americanista Europeo 12: 47-77.

- 2015a. Amerindian Misfortunes: Ethnographies of South American Rituals and Cosmologies on Danger, Illness, and Evil. Indiana 32: 9-22.

- 2015b. La iglesia de incahuasi. Notas sobre antropología simétrica, arquitectura e historia en los Andes peruanos septentrionales (ferreñafe, lambayeque). Revista española de antropología americana 45 (2): 551-568.

- 2016. Nuevos estudios sobre la peculiar iglesia virreinal de Incahuasi y la historia de una región postergada de los Andes (área Cañaris, Lambayeque, Perú). Indiana 33 (2): 145-160.

Rivera Andía, Juan Javier, and Peter Snowdon. 2013. The Owners of the Land. Culture and the Spectre of Mining in the Andes. Genk: Het Vervolg.

Rivera Andía, Juan Javier, José Cajo, Cristóbal Barrios, and José Gaspar. 2017. ¿Quiénes son los cañaris del perú? Aspectos históricos y etnológicos de la relación con la tierra y el medioambiente de un pueblo ignorado y amenazado en la sierra de lambayeque. In El concepto de lo sagrado en el mundo andino antiguo: espacios y elementos pan-regionales, ed. A. Yépez, V. Moscovich, and C. Astuhuamán. Quito: PUCE.

Robin, Valerie. 2010. La petrificación de los antiguos en Chumbivilcas (Cuzco, Perú). De la wanka prehispánica al actual ramadero. Revista Española de Antropología Americana 40 (1): 219-238.

Salas Carreño, Guillermo. 2008. Dinámica social y minería. Familias pastoras de puna y la presencia del proyecto Antamina (1997-2002). Lima: IEP.

- 2016. Places are Kin: Food, Cohabitation, and Sociality in the Southern Peruvian Andes. Anthropological Quarterly 89 (3): 813-840.

Salvia, Daniela Di. 2014. La religión de la tierra en los Andes centrales: Imágenes simbólicas y trasnfondos ecológicos. Salamanca: Vitor.

Schavelzon, Salvador. 2016. La política indígena y la investigación en Bolivia. Revista de Antropologia 59 (3): 115-149.

Shaver, D. 1992. Organización socio-política de las comunidades campesinas: el caso de Inkawasi. In Estudios Etno-Lingüísticos II, ed. S. Parker. Lima: Ministerio de Educación-Instituto Lingüístico de Verano.

Silva Santisteban, Rocío. 2013. 96\% del distrito de Cañaris está concesionado. En: La República (01.05.2013). http://larepublica.pe/politica/708069-96-deldistrito-de-canaris-esta-concesionado. Accessed 26 Feb 2018.

Sotelo, Vicente, and Pedro Francke. 2011. ¿Es económicamente viable una economía postextractivista en el Perú? In Transiciones Postextractivismo y alternativas al extractivismo en el Perú, ed. Alejandra Alayza and Eduardo Gudynas. Lima: CEPES, RedGE.

Stengers, Isabelle. 1996. Cosmopolitiques. T1. La guerre des sciences. Paris: La Découverte.

Tanaka, Martín. 2012. ¿Por qué el Estado no responde adecuadamente a los conflictossociales? ¿Qué hacer al respecto? Economía y Sociedad 79: 36-43. 
Tomasi, Jorge. 2015. The House as a Moving Story: An Ethnography of Andean Domestic Architecture. In Vernacular Architecture: Towards a Sustainable Future, ed. C. Mileto, F. Vegas, L. García Soriano, and V. Cristini, 701-706. London: CRC Press.

Urrutia, Jaime. 1992. Comunidades campesinas y antropología: historia de un amor (casi) eterno. Debate Agrario 14: 1-16.

Viegas, Susana de Matos. 2016. Temporalities of Ownership: Land Possession and Its Transformations Among the Tupinambá (Bahia, Brazil). In Ownership and Nurture. Studies in Native Amazonian Property Relations, ed. Marc Brightman, Carlos Fausto, and Vanessa Grotti. New York: Berghahn Books.

Viveiros de Castro, Eduardo. 1999. Comments to 'Animism Revisited: Personhood, Environment, and Relational Epistemology'. Current Anthropology 40: 79-80.

- 2015a. The Relative Native. Essays on Indigenous Conceptual Worlds. Chicago: Hau Books.

- 2015b. Who Is Afraid of the Ontological Wolf? Some Comments on an Ongoing Anthropological Debate. The Cambridge Journal of Anthropology 33 (1): 2-17.

Vreeland, James. 1993. Danzas tradicionales de la sierra de lambayeque. In Música, danzas y máscaras en los Andes, ed. R. Romero. Lima: Pontificia Universidad Católica del Perú.

Weszkalnys, Gisa. 2016. A Doubtful Hope: Resource Affect in a Future Oil Economy. Journal of the Royal Anthropological Institute 22 (S1): 127-146.

Open Access This chapter is licensed under the terms of the Creative Commons Attribution 4.0 International License (http://creativecommons.org/licenses/ by $/ 4.0 /)$, which permits use, sharing, adaptation, distribution and reproduction in any medium or format, as long as you give appropriate credit to the original author(s) and the source, provide a link to the Creative Commons license and indicate if changes were made.

The images or other third party material in this chapter are included in the chapter's Creative Commons license, unless indicated otherwise in a credit line to the material. If material is not included in the chapter's Creative Commons license and your intended use is not permitted by statutory regulation or exceeds the permitted use, you will need to obtain permission directly from the copyright holder.

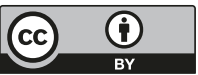




\title{
Carbon and Biodiversity Conservation as Resource Extraction: Enacting REDD+ Across Cultures of Ownership in Amazonia
}

\author{
Marc Brightman
}

\section{INTRODUCTION}

Forest carbon and biodiversity are increasingly measured and quantified with a view to improving their management as valuable resources, often with a view to engaging market mechanisms to improve cost-efficiency. If such resources are being 'marketised', in what ways does this process differ from conventional resource extraction such as logging or mining? Indigenous peoples, especially those for whom the forest is a home and 'biodiversity' is an abstract substitute for a world of everyday relations, can offer important insight into this question.

This chapter is a revised and updated version of texts previously published in French in Ethnographiques (Brightman 2014), and in Portuguese, in RURIS (Brightman 2016a). It is based primarily on research carried out during 2010-12 thanks to a Marie Curie Intra-European Fellowship at the Graduate Institute in Geneva.
M. Brightman ( $\square)$
University College London, London, UK
e-mail: m.brightman@ucl.ac.uk
(C) The Author(s) 2019
C. Vindal Ødegaard, J. J. Rivera Andía (eds.), Indigenous Life
Projects and Extractivism, Approaches to Social Inequality and
Difference, https://doi.org/10.1007/978-3-319-93435-8_8 
The concept of biodiversity emerged at the historical interface between the biological sciences and politics (Maris 2010). It is of particular interest to examine the politics of biodiversity in a country such as Suriname, which is part of the highly biodiverse Guayanan ecoregion (Olson and Dinerstein 1998), and has exceptionally extensive forest cover (90 per cent [FAO 2010]). Perhaps precisely because of this great abundance, the concept of biodiversity has little interest for most Surinamese people and is certainly not an electoral issue. Members of the majority urban, coastal population, if they express an opinion about the forest at all, tend to say there is too much of it, and their attitude towards people who live there tends to be of fear, contempt, or a mixture of both. There is a strong correlation between ethnic identity and habitat: descendents of freed slaves (Creoles) and indentured labourers (Hindustanis, Javanese, and others) are concentrated in the capital city of Paramaribo and on the narrow coastal strip that has been developed for agriculture and industry, whereas the inhabitants of the vast forested interior of the country are mostly Maroons and Amerindians. The former are descendents of runaway slaves who escaped Dutch plantations in the seventeenth century to form new tribal societies (Price 2011: 10). The Amerindians, the original inhabitants of the region, include a number of Carib and Arawak groups. For most Maroons and Amerindians, 'biodiversity' is not a meaningful category, but the variety and wealth of game animals, and useful plants, trees, and other species that are found in the forest play a fundamental part in their lives, not only in terms of subsistence but also as sources of meaning; what urban people call 'nature' is for them the theatre in which what we might call 'culture' is played out.

Some of the same things can be said about the other 'natural' or 'primary' resources of Suriname: goods such as gold, bauxite, or timber are found in the 'wild' interior (binnenland), and they are similarly coveted by international interests. The quantity of such resources is uncertain because of the limited amount of surveying that has been carried out, and this uncertainty can suggest a hitherto unexploited abundance. Extractive activities, therefore, rarely excite anxieties over resource scarcity, whether in the case of artisanal placer mining, of industrial timber or mining concessions, or of the thriving informal trade in bushmeat. Like mineral resources, it is widely assumed that the sources of tasty paca (Agouti paca), aimara (Hoplias aimara), or caiman (Caiman crocodilus) meat will long continue to provide their bounty. The perception of the forest's abundance, even excess, makes it hard to imagine otherwise. And the technical specialists (generally staff of conservation NGOs with training in conservation biology 
or geography appropriate for biodiversity surveying) who attempt to quantify new resources like forest carbon and biodiversity find that it is an even more difficult and complicated task than the quantification of conventional ones like gold or bauxite. ${ }^{1}$

Widespread indifference does not prevent the forest from having substantial political importance in Suriname, which arises from two quarters, both of which have significant international dimensions: these are, firstly, the increasingly close ties between development aid and concern for environmental sustainability, as a result of growing institutional recognition of global ecological crisis (Adams 1990; Sachs 2015) and, secondly, the rise to political prominence of the indigenous peoples' movement. This should be seen against the background of Suriname's recent history. Following independence from Holland, in 1975, the political situation rapidly declined, and the 'interior' was neglected until a military coup took place in 1980, of which one of the instigators, Desi Bouterse, quickly rose to prominence and became President two years later. The new regime began to institute a development programme for the interior, but this was short lived, because an Ndjuka Maroon, ${ }^{2}$ Ronnie Brunswijk, who had been a member of Bouterse' personal guard, began to form his own military unit in the east of the country, and a series of raids and reprisals led to a descent into full-scale civil war. As a consequence of this 'war of the interior', the interior of Suriname, especially the Maroni River basin in the east where the majority of the Maroon population lives, was neglected to the extent that some have described it as a 'stateless zone' (Jolivet 2007; Kruijt and Hoogbergen 2005). When the fighting ended with a peace agreement, a coalition government agreed to an International Monetary Fund structural adjustment programme in 1991 and tried to attract foreign investment in the forestry and mineral sectors. But the postwar stability was short lived: the opposition party won the 1996 elections bringing Bouterse to power again, and the economy fell into decline together with diplomatic relations with Holland-the main aid donor and former colonial power (Kambel and Mackay 1999: 13). The state meanwhile granted concessions in the interior (while some areas have been exploited outside its control, notably for gold), giving rise to conflict over land rights with wide-ranging implications, as I shall discuss in greater detail below (see also Price 2011).

In November 2011, I interviewed the Minister of Physical Planning, Land, and Forest Management of Suriname, together with his immediate entourage, about the changing stakes in the relationship between the government and the country's indigenous peoples in relation to land. One 
official with several decades of experience emphasised two things. The first was the fact that, the Amerindians ('Indianen'), who are becoming increasingly well organised politically, are putting pressure on the government to recognise their rights to land, making claims apparently in tension with evidence that some Amerindian communities are overexploiting their forest resources to sell garden produce for cash, in order to build large houses and purchase consumer goods. The second was that in the southern part of Suriname, where there are no roads and scarcely any other infrastructure, Suriname's genetic resources are, according to him, being plundered. $\mathrm{He}$ gave the example of the dyeing dart frog, Dendrobates tinctorius, which, he claimed, existed at first in Suriname alone, and which is now 'spread out' around the world due to clandestine trading. The Amerindians are being paid disproportionately small sums of money for these creatures, which command much higher prices abroad. But the most serious problem, he argued, is that Suriname loses its sovereignty over the genetic resources that are synthetically altered in foreign countries and then patented.

My own field research confirms that the Trio, a Carib-speaking people who live on the Sipiliwini Savannah on Suriname's southern border with Brazil, do trade in a number of species of live animals (including species of Dendrobates), for which they are paid small amounts in relation to international prices. ${ }^{3}$ In this border region, it is unlikely that many species are unique to Suriname, and the Dendrobates tinctorius can, in fact, be found in other parts of the Guiana shield region. I am not sure how serious a problem foreign gene patenting really is for Suriname. But what strikes me here is the way in which the government officials spontaneously and emphatically linked the matters of land rights, biodiversity, and national sovereignty. In this chapter, I show that the value of land for a native Amazonian people is also linked to biodiversity and sovereignty but in different ways: rather than conceiving land separately from its nonhuman inhabitants, the Trio value land in terms of the relations between the living actors that dwell there.

\section{LAND Rights}

Indigenous claims to land rights are often perceived as being in conflict with state sovereignty. But the nature of legal rights is such that the opposite may be argued: " "the right to land" in most cases ... [entails the right to] a certain territorial area embedded within a state. This condition renders many of indigenous peoples' rights conditional upon the wider 
national entity wherein they reside, plus the status of the latter within the international community' (Westra 2008: 23). It is to a significant extent due to its postcolonial history of war and corruption that Suriname has become the only country in South America never to have passed any kind of land reforms in favour of its indigenous peoples (whose situation is generally considered alongside the larger Maroon groups legally categorised as 'tribal peoples'). In recent years, it has come under increasing pressure to do so. This pressure comes from the internationalisation of campaigns for indigenous and tribal rights, through initiatives coming from both within and outside Suriname. Two of these appear especially significant. The first is the successful campaign of the Saramaka Maroons for compensation over environmental damage and the displacement of communities due to the construction of the Afobaka Dam in their territory. This led to the landmark ruling (Saramaka v. Suriname judgement) of the Inter-American Court of Human Rights of 28 November 2007, which declared that Suriname had violated the rights of the Saramaka People. The ruling declared that Suriname must seek the Saramaka's prior and informed consent for any intervention that might threaten their sexistence as a tribal people, highlighting that 'land is more than merely a source of subsistence; it is also a necessary source for the continuation of the life and cultural identity of the Saramaka people' (para 82) (Orellana 2008: 842). The Court thus puts Suriname under pressure to accept and adopt its interpretation of customary international law, based on an understanding of culture as land, which envisions a communal conception of property (Engle 2010: 167). ${ }^{4}$

The second initiative is REDD+ (Reduce Emissions from Deforestation and forest Degradation in developing countries), the emerging UN-sponsored mechanism for 'reducing emissions from deforestation and degradation "plus" conservation, sustainable development of forests, and improvement of carbon stocks' (IUCN 2012), for which the Surinamese state has been in the process of preparing since 2009. This programme can be understood as a giant system of payments for ecosystem services, similar to the carbon offsetting that constitutes most of the existing 'voluntary' market in forest carbon. ${ }^{5}$ Its founding principle is that countries that preserve or increase their forest cover should be paid for the opportunity $\operatorname{costs}^{6}$ of doing so. It involves a set of 'safeguards', including provisions for the protection of forest peoples from abuses such as land grabs (these provisions' effectiveness is a contentious subject). In March 2013, Suriname's 'readiness preparation proposal' (R-PP) for REDD+ was approved by the 
World Bank's Forest Carbon Partnership Facility, allowing Suriname to receive USD 3.8 million for technical preparations for joining the REDD+ mechanism, scheduled to come into force in 2020. The R-PP was severely criticised by Suriname's indigenous and tribal representatives and by the international indigenous rights advocacy organisation, Forest People's Programme (FPP), for making disingenuous claims about the consultation process and about guarantees to address and protect indigenous and tribal land tenure (FPP 2013).

The 'readiness' process in preparation for REDD+, taking place shortly after the Saramaka ruling, provided the context for short-lived land rights negotiations between the government of Suriname and its indigenous and tribal peoples. When I visited the secretariat of the VIDS (Vereniging van Inheemse Dorpshoofden in Suriname) indigenous leaders' organisation in the summer of 2011 , its members were excitedly preparing for a longawaited government conference on land rights for Amerindians and Maroons. When this took place in October 2011, the VIDS representative gave an opening speech, which set out the organisation's demands for full recognition of indigenous rights to land. President Desi Bouterse, the former military dictator who had returned to power by popular vote in 2010 , reacted by summarily closing the conference on the grounds that the agreed protocol for discussion had not been observed. Further negotiations have been promised but have not so far taken place even following a landmark ruling by the Inter-American Court of Human Rights in 2015 on the case of the Kali'na and Lokono of the lower Maroni River, whose livelihoods were severely affected by a bauxite concession granted in 1958 (Namati 2015).

REDD+ takes on different characteristics according to the actors who are imagining it. For politicians, it represents a further opportunity to capture international funding, ostensibly for the nation, but often (as history shows) for personal gain. For Amerindian and Maroon leaders and other individuals sufficiently aware of the issues, it is at best a doubleedged sword and something to be treated with extreme caution: while it may offer an opportunity to increase the pressure for state recognition of customary land rights and seems to invite further international scrutiny of the practices of national institutions, it may also create perverse incentives for outsiders to attempt to disenfranchise them still further. For conservation NGOs, there seems little doubt: the prospect of REDD+ reinforces their role as technical and research specialists in the field of forest governance. 


\section{Ownership in Amazonian Societies}

Indigenous leaders are likely to be correct in thinking that the prospect of REDD+ makes it still more urgent for them to secure their land titles; indeed, speculation over the potential value of forest for carbon sequestration has already led to land grabs in other parts of Amazonia (FPP 2012). At the same time, the conditions of REDD+ place governments under pressure to recognise these rights (Sommerville 2011). But indigenous land rights debates nearly always take place in terms quite foreign to indigenous systems of property relations. Until recently, the idea of property was even absent or confined to footnotes in most Amazonian ethnography. In the last few years, along with a handful of colleagues, I have been trying to explore native Amazonian forms of ownership (Brightman et al. 2016; Costa 2010; cf. Guzmán-Gallegos this volume). Contrary to received wisdom, the concept of ownership is present in many, if not all, aspects of native Amazonian cosmologies (Brightman 2010). Fausto compares Kuikuro ownership to Marilyn Strathern's idea of the magnified person, according to which the single entity represents and encompasses the group category: in this sense, leaders personify their villages as well as being their 'owners', and the spirit masters of game animals are the personifications and 'owners' of the species (Fausto 2008). ${ }^{7}$ Among the Kanamari, the concepts of owner and body are conflated, and Luiz Costa traces the owner-body-chief concept through a nested hierarchy 'from living bodies, to village chiefs, to the chiefs of river basins' (2012). In my own work, I have emphasised the processual nature of ownership in Amazonia (Brightman 2010, 2016a, b) ${ }^{8}$ Objects become property by virtue of having been transformed or made by their owners. The clearest and most important example of this is the swidden, which is appropriated from the forest to become the property of the gardener; after a swidden is abandoned, it gradually reverts to being the property of nobody in particular as it is reclaimed by the forest.

The processual nature of kinship has received a great deal of attention in Amazonian ethnography, and it is through it that the two perspectives on property described above, emphasising mastery and transformative processes, respectively, meet. Fausto's discussion of ownership builds on his analysis of familiarising predation, that is, the process by which outsiders can be adopted by turning them into asymmetric consanguines in the form of children or pets. Similarly, in her ethnography of the Trio, Vanessa Grotti has described the nurturing or feeding processes involved in domesticating 
enemy groups - this can be seen as the 'work' of appropriation in the sphere of kinship (Grotti 2007; cf. the 'care' described by Rivera, this volume). The transformation of forest into garden, similarly, is a process of domestication. As has been widely documented in Amazonia, garden plants are nurtured and cared for as kin. Similarly, pet animals, which are called by kinship terms and fed human food (especially manioc bread) are frequently game animals and are often juvenile offspring of animals that are taken in the hunt. Ownership and appropriation of nonhumans occur in the idiom of kinship; the appropriation of forest, and thus the revaluation of 'land', occurs through the cultivation of domesticated plants-it is an act of domestication in itself, as the domestication of place. ${ }^{9}$

The vectors of ownership and appropriation do not always overlap. In an article which successfully blurs Philippe Descola's distinction between Amazonian societies that relate to nonhumans through predation and through reciprocity (1992), Peter Rivière notes that the Trio do not simply regard all animals, or even all game animals, as having spirit masters (2001). He contrasts three Trio myths in which a shaman encounters nonhuman animals. In the first two, which involve a spider monkey and a tapir, respectively, the shaman only meets the animals themselves, not the spirit master of the species in question. They do not communicate successfully, their relationship is characterised by mistrust, and the humans and animals end by predating upon each other. In the third myth, the shaman meets the master of white-lipped peccary, and they enter into a ceremonial dialogue. The peccary master agrees to release peccary for humans to hunt, although he warns that the peccary will steal from the humans' gardens. As Rivière notes, the Trio regard peccary as a more sociable species than tapir or spider monkey. They are related to in a human way through their spirit master, and a relationship of reciprocity ensues. It seems to me that a similar logic applies to land. The Trio relate to different places in a more sociable, or reciprocal way, or a more predatory way, according to the level of sociability, or humanity, of those places.

\section{Trio Property Relations}

The Trio are composed of a number of different groups, which came to live in mission stations in the mid-twentieth century and began to intermarry. Little more than 2000 in number, they live on both sides of the international border between Suriname and Brazil. They live mainly from swidden horticulture - their main crop being bitter manioc-as well as 
hunting, fishing, and gathering, but some Trio have paid employment and others trade forest products. As a result, they are increasingly part of the cash economy.

The Trio distinguish two basic categories of land: first, there is the cleared space of the village, pata, or garden, tëpitë. Second, there is the forest, $i t u$. The way of being in each spatial category is differentiated linguistically through the use of two different postpositions: - po, and -tao. Although both of these postpositions could be translated as 'in', pata-po ('in the village'), or tëpitë-po ('in the garden'), both draw attention to the fact of being in a humanised, culturally transformed place, while itubtao ('in the forest') suggests being located within a physical medium or environment. It is significant that the postposition -tao is also used for water, or the river- 'in the water or river' is tunabtao. The aquatic realm is the quintessential domain of spirits and other mythical beings and is even more plainly associated with alterity than the forest. The distinction between these two kinds of space mirrors property relations. Swiddens, tëpitë, are owned by individual families; itu, 'forest', is not owned by human persons, and neither is the water. A village is owned by its leader, who is also literally referred to (among other things) as pata entu, village owner.

However, seen through time, the distinction between these kinds of space and their status in terms of ownership is not so clear. New swiddens tend to be cut in places where the forest has reclaimed abandoned swiddens over time. The same applies to villages: when a new village is created, the best places for building are said to be those in which people dwelt in the past. In fact, the two processes are connected: when new villages are created, they begin as a garden with a house in it, and it is partly because gardens tend to be relocated more frequently than villages that the two categories, garden and village, become separated, as new gardens are cut further away from the houses.

Trio people do not consider old gardens and old villages to be the property of particular families. They are recognised as 'appropriable', as potential spaces for human habitation and cultivation because they bear the marks of human action. The markers of previous domestication include domestic plant species-manioc, fruit trees, and so forth-as well as other signs such as petroglyphs and rocks marked by grooves where they were used for sharpening tools. They are places which were transformed by humans in the past and thus appropriated, but the traces of individual identity have disappeared. A process of forgetting thus ensures that such places are not monopolised by particular families. Anne-Christine Taylor 
has already drawn our attention to the importance of forgetting the dead in Amazonian societies (1993). But what I want to underline is that such places are not entirely 'wild' - the marks of human habitation and exploitation identify them as generically buman places. If the process of transforming land for cultivation is an act of appropriation, it is highly significant that it is not permanent. Yet this should be seen in the context of a notion of territory, in which Trio people regard themselves as free to cultivate, hunt, and fish and to manage their own affairs independently-as such, they have sovereignty in this territory.

\section{VALUing RELATIONS}

David Graeber proposed creating a theory of value 'starting from the assumption that what is ultimately being evaluated are not things, but actions' (Graeber 2001: 49). It seems to me that the Trio, when they 'value land', do not value a thing but sets of actions and relations. As I have tried to show, the value of land for the Trio is explicitly relational. The anthropology of property has tended to define property as relations between persons with respect to things (Hann 1998). But, here, it seems that property relations are relations between persons, full stop. The mastery or ownership relation structures the status of a garden as property of its creator in the same way as a leader is master-owner of his village and as a spirit master is owner of an animal or plant species. As the myths of the peccary, the tapir, and the spider monkey suggest, the appropriation of resources from the environment is a matter of interpersonal predation or reciprocity. The preparation of meat for consumption entails the return of the prey animal's soul matter to the forest, and the gardens are left open to encourage nonhuman animals, including game animals, to feed on the crops. There is no objective value of a given piece of land because its value changes through time. Its value is also created through time as the product of the nurturing processes of previous gardeners.

Meanwhile, value, ownership, and the act of appropriation do not necessarily map neatly onto one another. Certain wild species of plant are gathered, and they are certainly valued, although they are not 'owned' by humans; in such cases, it is not always obvious whether the appropriation of the products of these plants constitutes an act of predation or is involved in a relationship of reciprocity-this seems to vary from one species to another. As authors such as William Balée, Darrell Posey, and Laura Rival have shown (Posey and Balée 1989; Rival 2002), the distinction between 
wild and domestic species is often far from clear. But this matters little in practice because property is not treated as thoroughly exclusive-stealing from somebody's garden is not a serious offence, and in their ordinary lives, the Trio have little use for hard forms of 'property rights' ${ }^{10}$ to decide who can appropriate which resources at what time.

\section{Regimes of VALUe}

Despite their remote location in southern Suriname, far from roads and deep rivers, the Trio are not entirely isolated from the effects of state attempts to control resources and territory, international markets, or the politics of rainforest conservation. Considerable changes took place in their way of relating to the forest in the early 1960s as a result of the cutting of airstrips by the Surinamese army for the creation of mission stations, in parallel with an equivalent process on the Brazilian side of the border. Encouraged by the missionaries and attracted by the prospect of direct access to white people's trade objects (bypassing their Maroon trading partners), most Trio moved to live at these mission stations over a period of a few years. In fact, there were a number of different groups, such as the Okomojana, the Aramiso, the Piropï, and the Pirëujana, whose identities became submerged through this process of sedentarisation as they adopted the common language of Tarëno-literally, 'the people here'.

More recently, the Trio have been involved with two conservation NGOs, Conservation International (CI) and Amazon Conservation Team (ACT). The former has been involved in the region for many years and indeed dominates conservation in both Suriname and neighbouring Guyana (Chapin 2004). ACT was created by ethnobotanist Mark Plotkin when he left CI to pursue his own projects, giving greater emphasis to traditional knowledge and livelihoods, and grew out of his own field research in Suriname (Plotkin 1994). The main emphasis of CI has tended to be upon documenting biodiversity, while ACT takes a social entrepreneurship approach to promoting 'sustainable development' through markets and preserving traditional knowledge. Both have been involved in mapping projects. Using what are known as 'participatory methods', ACT has produced maps of traditional resource use, with the explicit purpose of providing evidence upon which to base land rights claims. This is highly significant in Suriname, which has so far not recognised or demarcated any indigenous or tribal territories (Kambel and Mackay 1999; Price 2011). Meanwhile, CI received a government mandate to produce a forest inventory map for 
the whole of Suriname, which they did using satellite technology (Gwendolyn Smith pers. comm. 2011). Also, near the largest Trio village of Kwamalasamutu, CI collaborated with the Trio to create two protected areas. One of these is based around wërepai, a petroglyph site which was discovered only recently, but which the Trio recognise as having been made by their ancestors. CI describes this as a 'sacred site' and claims that for this reason, the Trio agreed to impose hunting restrictions around it. The other area was created following an interesting exchange between the village leader Asonko (who is also the Trio Granman, or 'tribal' chief, a title conferred by the state [see Brightman 2016b]) and CI: according to the CI director, Asonko asked her for help to create a farm for game animals because the village had grown so large that overhunting had become a problem. She told him that it was impossible, but that, instead, she could help him make a restricted area for hunting to allow the animals to breed. The project went ahead and CI's monitoring suggests that it has been successful in preserving stocks of game animals.

The whole interior of Suriname is officially state property. The state does not recognise indigenous forms of ownership (cf. Guzmán-Gallegos, this volume) or even the capacity of Amerindians to manage their own protected areas. The only official conservation areas that exist are state managed with some responsibility delegated to NGOs. Although traditional swidden cultivation and hunting are allowed in these areas, swidden horticulture is officially regarded as a form of forest degradation and this misconception forms part of the rationale for refusing to recognise indigenous peoples' forest management capability.

When President Bouterse returned to power, in 2010, he announced that a memorandum of understanding had been set up with China for the construction of a road to the Brazilian frontier, and plans are underway to build a hydroelectric dam, which would flood some Trio, Wayana, and Maroon villages. It is for the purposes of preparing for REDD+ that the Surinamese government commissioned a forest inventory map from CI. The infrastructure projects of a road and dam would, of course, cause massive deforestation, which is highly significant for REDD+, because the payments that the government would receive under REDD+ are to be calculated in terms of opportunity costs, on the basis of alternative future development scenarios. In other words, the infrastructure plan, which, if executed, would cause deforestation and significantly increased carbon emissions, serves to manipulate the baseline for calculating REDD+ payments in terms of avoided emissions. As a result of all of this, the political 
situation between the government and forest peoples remains tense. Surinamese indigenous and Maroon organisations recognise that they must campaign for their land rights before consenting to any involvement in REDD+. The government also claims to accept that it will have to recognise indigenous land rights in order to qualify for REDD+ funding. The NGOs, CI, and ACT are playing the role of mediators and brokers, helping the government with technical procedures while trying to encourage it to recognise indigenous practices and at the same time trying to explain the REDD+ mechanism to both indigenous peoples and government staff.

\section{VALUE AND MARKETS}

REDD+ is catalysing the emergence of a new marketable commodity: forest carbon. Unlike previously existing carbon markets, which are based on emissions trading, forest carbon is based on the estimated value of the carbon emissions deemed to be avoided through conservation. One aspect of the 'plus' element of REDD+ is a biodiversity value. Without entering into debates about the competing definitions or criteria for measuring biodiversity, discussions of REDD + emphasise the latter's instrumental value as potentially commodifiable intellectual property and as a necessary component of ecosystem functioning. Such 'ecosystem service' values shadow the value of conventional natural resources-especially timber and minerals - as opportunity costs. This reflects the prevailing neoclassical assumption that markets will stabilise a 'correct' price for commodities (carbon, biodiversity) - a view that is contested by scholars who show how value in new markets is the product of a range of social interactions and the development of market infrastructures (Barman 2015; Callon 2009; Callon and Muniesa 2005).

These market calculations can only be made on the basis of accurate measurements of the resources and services in question: it is for this reason that the government has recruited a Dutch company to carry out a full survey for the proposed hydroelectric dam project, and that it commissioned CI to produce a national forest inventory. Indeed, while it is a standard practice to carry out surveys in advance of corporate mining or logging activities (leaving aside the important informal sector), the large-scale measurement of carbon and biodiversity stocks is something relatively new. Consequently, an important part of Suriname's REDD+ programme, as with other countries, is what is known as MRV-monitoring, reporting, and verification. Against the baseline of the forest inventory, national governments are responsible 
for putting in place technical capacity to monitor forest conservation, to report any deforestation or degradation, and to verify the government's official data. These activities are sometimes known for short as 'carbon accounting', and their importance is such that forest carbon (and similarly biodiversity) must be continually audited in order for them to have any kind of sustained and recognisable existence, and thus to have any political and economic effect.

It is worth noting here that the extraction of value from forests in the form of biodiversity and carbon depends upon the work of measurement and accounting in much the same way that the extraction of other resources depends upon the physical work of removal. But these are, of course, very different kinds of 'work', and it is debatable to what extent the marketisation of forest carbon and biodiversity amount to 'extraction' at all.

\section{PATHS AND MAPS}

The use of measurement and quantification techniques to value resources seems foreign to the Trio's relational mode of land use. Two different temporal modes are also at play here: for the Trio, a certain focus on the present is crucial for the forgetting of past ownership relations and for the cycle of abandonment and regeneration of garden sites to continue without causing tension. This is expressed in Trio kinship, which does not trace ancestry or genealogies, and does not even distinguish between consanguines and affines beyond two generations. In contrast, forest accounting requires accurate time measurement, for environmental services are meaningless without reference to their sustained provision through time. ${ }^{11}$

At this point, it may be worth distinguishing two forms of mapping activity: on the one hand, there is the documenting of traditional resource use through cartography for the purposes of land claims and the eventual demarcation of indigenous territories. On the other hand, there are various scientific surveying activities to quantify resources: forest carbon, biodiversity, game animals, timber, and subsoil mineral resources. The Trio themselves see these as virtually identical cultural processes of measurement and quantification. However, they do relate to them in different ways. ACT's map-making activities have been requested by Trio leaders themselves, and Trio individuals have participated in them in return for a small salary. CI's biodiversity surveys have always been CI's own initiatives, although they do also sometimes employ Trio people and solicit their input. CI's work has sometimes been regarded with suspicion by 
Trio, particularly biodiversity surveys that were carried out recently in the area likely to be affected by the planned hydroelectric dam. Some Trio people suspected CI of preparing to expropriate their land and working for the government to measure the resources that could be extracted before the dam would be built (in fact, it seems that CI was compiling evidence of the conservation risks of building the dam).

Some Trio are also wary of ACT's work, wondering what their interest is-does Mark Plotkin, ACT's charismatic leader, plan to take the resources for himself? ACT's activities are also the cause of some tension because they are felt by some to be ungenerous since they pay small salaries and only recruit a handful of individuals. Not only do these individuals benefit from a small but not insignificant income but also their knowledge is privileged when maps of resource use are created. If ACT's maps are as inadequate as the Forest Peoples' Programme (FPP 2013) and VIDS suggest (a judgement not entirely free from political motivations), then these are likely to be among the underlying reasons. ${ }^{12}$

Valuation surveys for the purposes of land claims and REDD+ involve a complex and often tense set of interactions between technicians and Amerindians. At the end of these interactions, it seems that both parties remain with their assumptions and worldviews more or less intact. Yet the solutions that emerge and the nature of the activities in which they collaborate often do not meet the expectations of either party. When Asonko suggested creating a farm, he may have imagined himself becoming a kind of supreme master of animals, an image likely to have been inspired by missionary teaching which has encouraged the view that Jesus is the master of all beings and that he benevolently condones the unlimited hunting of all food species. The CI director saw the potential for a collaboration on a community-managed, restricted hunting area, an important experiment which could support her advocacy of community-managed conservation areas vis-à-vis the government.

Perhaps we should interpret this as an example of 'equivocal compatibility' (De Piña Cabral 2005) or a 'working misunderstanding' (Sahlins 1982) as Trio people become involved in conservation and mapping activities for reasons of their own, and serendipitous results emerge, sometimes to the satisfaction of all concerned, if not quite in the ways they expected. But I think that what is going on is a little more complicated. As I have mentioned, for Trio people, the process of mapping for demarcation raises suspicion because they recognise that the land is being subjected to a process of measurement for the sake of appropriation. According to the Trio's own 
anthropology of white people, measurement and appropriation are closely linked, and they are not far wrong (cf. Stensrud, this volume). Even though the NGO workers regard the Trio themselves as the beneficiaries of this process, there is a sense in which the process itself dispossesses them. The land becomes property under a regime foreign to the Trio, even if it is legally theirs - the legal system in question is not their own. Meanwhile, the technological removal of ambiguity in property relations ensures that there will be tension, and that the ultimate arbiter of that tension will be the state, which will thus have an opportunity to reassert its authority. This helps answer the question of whether the marketisation of carbon and biodiversity can be understood as a process of resource extraction: while it does not involve the physical extraction of resources from the environment, it does involve an act of appropriation through the imposition of different categories of knowledge and ownership: a kind of cross-cultural extraction of wealth. It is thus only in this limited sense that it contributes to the commodification of new areas of life in the form of biodiversity.

\section{Conclusion}

This last observation begs the question: do more formal, technical forms of knowledge and ownership (what James Leach [2016] calls 'property' as opposed to 'ownership'), therefore, always necessarily overcome or disrupt more relational modes of knowing and owning? The following example may suggest that they do: near the Tapanahoni river, there is a tepui mountain which has mythical associations for both the Wayana (Caribspeaking neighbours of the Trio) and for the Ndjuka Maroons. For the Wayana, it is a place of origin and a place of the dead: it is a tukusipan, an architypal house. For the Ndjuka, it is a sacred site associated with ancestral spirits. The Wayana and Ndjuka fought a war against each other in the nineteenth century, but they finally made peace, and, according to the Wayana's version of events, the leaders of the two warring groups drank each other's blood to seal their peace. Having established shared substance through this ritual gesture, they agreed to respect the limits of their respective territories. Their cohabitation was made easier by the ambiguity in the precise boundaries of these territories, such that the tepui in question did not become the exclusive property of either group. Now, however, both Wayana and Ndjuka territories have been mapped with a view to obtaining official state demarcation of ancestral lands. This has given rise to a dispute over who owns the sacred mountain. ${ }^{13}$ 
In this case, there was no great equivocation over what was going on when the mapping process was carried out. Amerindian and Maroon guides worked for ACT to produce maps of their traditional resources, including places of ritual or mythical importance. However, the value of land for the Wayana and Ndjuka was not based on its value as a commodity, and the mapping process treated cultural property as though it were just that. For this reason, the result of a fairly smooth technical collaboration was the revelation of the incompatibility of two regimes of value.

Nevertheless, the codes of ownership and knowledge that are woven by formal extractive techniques can also provide a space for dialogue once they have been given time to establish themselves as a common language. Indeed, the interactions between CI and ACT with the Trio gradually overcame some of the latter's scepticism, and in 2016 Granman Asonko finally agreed on behalf of all the Trio to cooperate with the REDD+ 'readiness' process (SurinameREDD 2016). Without presuming to judge whether or not he made the 'right' decision, the point worth noting here is that the Trio could see a mutual interest in REDD+ for themselves and the technocratic 'white' outsiders, establishing a partial connection with the latter and partially adopting their ways of knowing in a 'both and' move similar to that described by Guzmán-Gallegos (this volume). This contrasts with both forms of primary resource extraction: formal, industrial mining and logging and informal placer mining for gold. What distinguishes these from carbon and biodiversity is not only their physical (rather than virtual) mode of extraction but also the related fact that they treat the forest as a wild frontier, a resource frontier-an attitude incompatible with the Trio's cosmology and livelihood. Carbon and biodiversity valuation, on the other hand, treat the forest environment as a world of complex socioenvironmental interactions, and practitioners share this approach with the Trio despite their differing epistemology and techniques.

\section{NoTes}

1. Timber, of course, cuts across the categories of conventional primary resources, forest carbon, and biodiversity and can be qualified and quantified in terms of any of all these categories.

2. Maroons are descendants of Africans who escaped Dutch slave plantations as early as the eighteenth century. Suriname has the largest maroon community in the Western hemisphere including six tribes: the Djuka or Ndjuka and the Saramaka (each 15,000-20,000 people); the Matawai, the 
Aluku and the Paramaka (each around 2000), and the Kwinti (fewer than 500) (Price 1976: 3-4). Greatly outnumbering the Amerindian population upstream, they dominate the middle reaches of the Saramacca, Suriname, and Maroni rivers and the lower parts of the Tapanahoni and Lawa, tributaries of the Maroni.

3. I have carried out nearly two years of field research in Suriname and neighbouring French Guiana since 2002, the majority of which was conducted among the Trio, Wayana, and Akuriyo.

4. To consider indigenous forms of property relations as common property regimes has the advantage of recognising many of the most important implications of their distinction from private property regimes but greatly simplifies their structural features and mode of functioning, especially their processual and situational aspects (Brightman et al. 2016).

5. There is a vast and growing critical literature on REDD+ (reduce emissions from deforestation and forest degradation in developing countries). For a summary, see Hufty and Haakenstad (2011). See also (Burnham 2012; Dooley et al. 201 1; Kricheff 2012; Pokorny et al. 2013; Rival 2013; Smith 2010; Sullivan 2013; The Munden Project 2011; Van Dam 2011).

6. An opportunity cost is 'a benefit, profit, or value of something that must be given up to acquire or achieve something else' (Business Dictionary n.d.).

7. The role of cosmological owners in Amazonia may be compared with that of 'earth-beings' in Andean societies (see Stensrud, this volume).

8. The importance of historical processes in the constitution of ownership relations and 'ontogeny' is eloquently discussed in an Andean context by Rivera Andía (this volume).

9. Similar processes have been described in Andean ethnography (Rivera pers. comm. 3 November 2017).

10. It is useful to distinguish between formal, usually private property regimes and relational regimes of ownership such as those of native Amazonian and Melanesian peoples. James Leach distinguishes these by reserving the term 'property' for the former and using the term 'ownership' to include the latter (Leach 2011; Brightman et al. 2016).

11. For further discussion of this topic, see Brightman (2012). For a comparable argument among a neighbouring people, see Mentore (2011). For relevant theoretical discussion, see Casey (1996).

12. Some management difficulties with ACT's (Amazon Conservation Team) Suriname programme during the period in question may also be partly to blame (M. Plotkin pers. comm. 2015).

13. Not all Ndjuka or Wayana are in agreement over whether or not there is, in fact, a dispute. One Ndjuka leader assured me that the two groups concerned are managing these changes amicably. 


\section{REFERENCES}

Adams, William. 1990. Green Development: Environment and Sustainability in the Third World. London: Routledge.

Barman, Emily. 2015. Of Principle and Principal: Value Plurality in the Market of Impact Investing. Valuation Studies 3 (1): 9-44.

Brightman, Marc. 2010. Creativity and Control: Property in Guianese Amazonia. Journal de la Société des Américanistes 96 (1): 135-167.

. 2012. Maps and Clocks in Amazonia: The Things of Conversion and Conservation. Journal of the Royal Anthropological Institute 18 (3): 554-571.

- 2014. Audit Sauvage: Régimes de valeur de la terre et de la biodiversité en Amazonie. Ethnographique(s) 27 (online journal). Available at http://www. ethnographiques.org/2013/Brightman. Accessed 15 Feb 2018.

_. 2016a. Esperança e Compatibilidade Equívoca na Governança da Floresta: REDD+e os Direitos Sobre a Terra Indígenas e Tribais no Suriname. RURIS 10 (1): 219-254.

. 2016b. The Imbalance of Power: Leadership, Masculinity and Wealth in the Amazon. New York: Berghahn.

Brightman, Marc, Carlos Fausto, and Vanessa Grotti, eds. 2016. Ownership and Nurture. Studies in Native Amazonian Property Relations. New York/Oxford: Berghahn Books.

Burnham, Philip. 2012. Climate Change and Forest Conservation: A REDD Flag for Central African Forest People? In Climate Change and Indigenous Knowledge: Perceptions and Adaptations of Threatened Communities, ed. David Brokensha, Peter Castro, and Dan Taylor. Rugby: Practical Action Publishing.

Business Dictionary. n.d. http://www.businessdictionary.com/definition/ opportunity-cost.html. Accessed 21 Oct 2017.

Callon, Michel. 2009. Civilizing Markets: Carbon Trading Between In Vitro and In Vivo Experiments. Accounting, Organizations and Society 34 (3): 535-548.

Callon, Michel, and Fabian Muniesa. 2005. Peripheral Vision: Economic Markets as Calculative Collective Devices. Organization Studies 26 (8): 1229-1250.

Casey, Edward. 1996. How to Get from Space to Place in a Fairly Short Stretch of Time: Phenomenological Prolegomena. In Senses of Place, ed. Steven Feld and Keith Basso. Santa Fe: School of American Research Press.

Chapin, Mac. 2004. A Challenge to Conservationists. World Watch Magazine 17 (6): 17-31.

Costa, Luiz. 2010. The Kanamari Body-Owner. Predation and Feeding in Western Amazonia. Journal de la Société des Américanistes 96 (1). http://jsa.revues. org/11332. Accessed 9 Oct 2013.

- 2012. Making Animals into Food Among the Kanamari of Western Amazonia. In Animism in Rainforest and Tundra: Personbood, Animals and Nonhumans in Contemporary Amazonia and Siberia, ed. Marc Brightman, Vanessa Grotti, and Olga Ulturgasheva. New York/Oxford: Berghahn. 
De Piña Cabral, João. 2005. Between China and Europe: Person, Culture and Emotion in Macao. London: Continuum.

Descola, Philippe. 1992. Societies of Nature and the Nature of Society. In Conceptualizing Society, ed. Adam Kuper. London: Routledge.

Dooley, Kate, Tom Griffiths, Francesco Martone, and Saskia Ozinga. 2011. Smoke and Mirrors: A Critical Assessment of the Forest Carbon Partnership Facility. Moreton-in-Marsh: FERN and Forest Peoples Programme.

Engle, Karen. 2010. The Elusive Promise of Indigenous Development: Rights, Culture, Strategy. Durham: Duke University Press.

FAO. 2010. Global Forest Resources Assessment 2010. Country Report: Suriname. Rome: Food and Agriculture Organisation of the United Nations.

Fausto, Carlos. 2008. Donos Demais. Maestria e Domínio na Amazônia. Mana $14(2): 329-366$.

FPP. 2012. The Return of Fortress Conservation: REDD and the Green Land Grab in the Peruvian Amazon. https://www.forestpeoples.org/en/topics/ redd-and-related-initiatives /news / 2012/10/return-fortress-conservationredd-and-green-land-gr. Accessed 19 Dec 2017.

- 2013. Comments on Suriname RPP (23 February 2013). http://www. forestpeoples.org. Accessed 3 Apr 2013.

Graeber, David. 2001. Toward an Anthropological Theory of Value: The False Coin of Our Own Dreams. New York: Palgrave.

Grotti, Vanessa. 2007. Nurturing the Other: Wellbeing, Social Body and Transformability in Northeastern Amazonia. PhD Dissertation, Cambridge University.

Hann, Chris, ed. 1998. Property Relations: Renewing the Anthropological Tradition. Cambridge, UK: Cambridge University Press.

Hufty, Marc, and Annie Haakenstad. 2011. Reduced Emissions for Deforestation and Degradation: A Critical Review. Consilience 5 (1): 1-24.

IUCN. 2012. REDD+ Explained. www.iucn.org. Accessed 22 Aug 2012.

Jolivet, Marie-José. 2007. Approche anthropologique du multiculturalisme guyanais: Marrons et créoles dans l'Ouest. In Pratiques et représentations linguistiques en Guyane: Regards croisés, ed. Isabelle Léglise and Bettina Migge. Paris: IRD Éditions.

Kambel, Ellen-Rose, and Fergus Mackay. 1999. The Rights of Indigenous Peoples and Maroons in Suriname. Copenhagen: IWGIA.

Kricheff, Daniel. 2012. Market Environmentalism and the Re-animation of Nature. Radical Anthropology 6: 17-25.

Kruijt, Dirk, and Wim Hoogbergen. 2005. Peaceful Relations in a Stateless Region: The Post-War Maroni River Borders in the Guianas. Tijdschrift voor Economische En Sociale Geografie 96 (2): 199-208.

Leach, James. 2011. The Problem of Property in Customary Tenure: An Example from Papua New Guinea. Paper presented at The Value of Land, Lisbon, 9-10, September. 
2016. Foreword. In Ownership and Nurture: Studies in Native Amazonian Property Relations, ed. Marc Brightman, Carlos Fausto, and Vanessa Grotti. New York: Berghahn.

Maris, Virginie. 2010. Philosophie de la biodiversité: petite éthique pour une nature en péril. Paris: Buchet/Chastel.

Mentore, Laura. 2011. Waiwai Fractality and the Arboreal Bias of PES Schemes in Guyana: What to Make of the Multiplicity of Amazonian Cosmographies? Journal of Cultural Geography 28 (1): 21-43.

Namati. 2015. Decision Details: Kaliña and Lokono Peoples v. Suriname. https:// namati.knack.com/casebase\#searchcases/decisiondetails2/57dc496c904df7a $1767 \mathrm{dlfd} 2 /$. Accessed 16 Oct 2017.

Olson, David, and Eric Dinerstein. 1998. The Global 200: A Representation Approach to Conserving the Earth's Most Biologically Valuable Ecoregions. Conservation Biology 12: 502-515.

Orellana, Marcos. 2008. Saramaka People v. Suriname. The American Journal of International Law 102 (4): 841-847.

Plotkin, Mark. 1994. Tales of a Shaman's Apprentice: An Ethnobotanist Searches for New Medicines in the Amazon Rain Forest. London: Penguin.

Pokorny, Benno, Imme Scholz, and Wil De Jong. 2013. REDD+ for the Poor or the Poor for REDD+? About the Limitations of Environmental Policies in the Amazon and the Potential of Achieving Environmental Goals Through ProPoor Policies. Ecology and Society 18 (2): 3.

Posey, Darrell, and William Balée, eds. 1989. Resource management in Amazonia: Indigenous and Folk Strategies. New York: New York Botanical Garden.

Price, Richard. 1976. The Guiana Maroons: A Historical and Bibliographical Introduction. Baltimore: Johns Hopkins University Press.

- 2011. Rainforest Warriors: Human Rights on Trial. Philadelphia: University of Pennsylvania Press.

Rival, Laura. 2002. Trekking Through History: The Huaorani of Amazonian Ecuador. New York: Columbia University Press.

- 2013. From Carbon Projects to Better Land-Use Planning: Three Latin American Initiatives. Ecology and Society 18 (3): 17.

Rivière, Peter. 2001. A predação, a reciprocidade e o caso das Guianas. Mana 7 (1): 31-53.

Sachs, Jeffrey. 2015. The Age of Sustainable Development. New York: Columbia University Press.

Sahlins, Marshall. 1982. The Apotheosis of Captain Cook. In Between Belief and Transgression: Structuralist Essays in Religion, History and Myth, ed. Michel Izard and Pierre Smith. Chicago: University of Chicago Press.

Smith, Gwendolyn. 2010. Carbon-Based Conservation Projects in Traditional Communities in Ecuador and Suriname: An Analysis of Vulnerability and Conflict Potential. Peace and Conflict Review 5 (1): 1-10. 
Sommerville, Matt. 2011. Land Tenure and REDD+: Risks to Property Rights and Opportunities for Economic Growth. Property Rights and Resource Governance Issue Paper \#11. USAID.

Sullivan, Sian. 2013. Banking Nature? The Spectacular Financialisation of Environmental Conservation. Antipode 45 (1): 198-217.

SurinameREDD. 2016. Krutu at Kwamalasamutu http://www.surinameredd.org/ en/news/events/2016/krutu-at-kwamalasamutu/. Accessed 16 Oct 2017.

Taylor, Anne-Christine. 1993. Remembering to Forget: Identity, Mourning and Memory Among the Jivaro. Man (N.S.) 28 (4): 653-678.

The Munden Project. 2011. REDD and Forest Carbon: Market-Based Critique and Recommendations. www.themundenproject.com. Accessed 24 May 2013.

Van Dam, Chris. 2011. Indigenous Territories and REDD in Latin America: Opportunity or Threat? Forests 2: 394-414.

Westra, Laura. 2008. Environmental Justice and the Rights of Indigenous Peoples. London: Earthscan.

Open Access This chapter is licensed under the terms of the Creative Commons Attribution 4.0 International License (http://creativecommons.org/licenses/ by $/ 4.0 /)$, which permits use, sharing, adaptation, distribution and reproduction in any medium or format, as long as you give appropriate credit to the original author(s) and the source, provide a link to the Creative Commons license and indicate if changes were made.

The images or other third party material in this chapter are included in the chapter's Creative Commons license, unless indicated otherwise in a credit line to the material. If material is not included in the chapter's Creative Commons license and your intended use is not permitted by statutory regulation or exceeds the permitted use, you will need to obtain permission directly from the copyright holder.

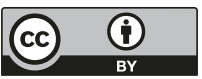




\section{Indigeneity, Activism, and the Politics of Nature}




\title{
Stories of Resistance: Translating Nature, Indigeneity, and Place in Mining Activism
}

\author{
Fabiana Li and Adriana Paola Paredes Peñafiel
}

\section{INTRODUCTION}

In April 2016, Máxima Acuña, a campesina (peasant farmer) from the highlands of Cajamarca, Peru, was one of six people awarded the Goldman Environmental Prize, ${ }^{1}$ considered one of the most prestigious awards for grassroots environmental activists. For many who had followed her struggle against Minera Yanacocha (the Yanacocha Mining Company), Máxima's international recognition as an 'environmental hero' was a welcome turn of events following years of fierce opposition to the Conga mining project. Marches, roadblocks, confrontations between police and protestors, and five lives lost in the conflict ultimately led to the suspension of the project and the company's retreat. Máxima's award, the publicity that followed, and the sharing of her story in documentary films, media articles, and activist campaigns are a testament to the global reach of recent controversies over extractive activity in Latin America. Her struggle, along

\section{F. $\operatorname{Li}(\bowtie)$}

University of Manitoba, Winnipeg, MB, Canada e-mail: fabiana.li@umanitoba.ca

A. P. Paredes Peñafiel

Universidade Federal do Rio Grande, São Lourenço do Sul, Brazil

(C) The Author(s) 2019

C. Vindal Ødegaard, J. J. Rivera Andía (eds.), Indigenous Life

Projects and Extractivism, Approaches to Social Inequality and

Difference, https://doi.org/10.1007/978-3-319-93435-8_9 
with those of other women activists, also illustrates the way grassroots efforts are transformed by (and in turn help shape) forms of political action beyond their immediate localities.

Over the past two decades, resource extraction in Latin America has generated numerous conflicts throughout the region but perhaps nowhere as intensely as in Peru. Two factors are important for understanding the context of these emerging conflicts. The first is that the rapid expansion of mining is linked to economic reforms in the 1990s that created a favourable climate for transnational investment. This meant a dramatic increase in mineral exploration and mineral concessions, which affect more than half of Peru's campesino (peasant) communities. Secondly, the diversification of the global mining industry, the high price of metals, and new mining technologies made it profitable to mine very low-grade ore. Consequently, mining has expanded into areas never before used for mining activity, including areas formerly devoted to agriculture and farming.

As we have explored elsewhere, mining conflicts have brought about forms of political action that disrupt and exceed nature-culture divides (Paredes Peñafiel and Li 2017). Water, glaciers, lagoons, and sentient mountains have acquired political significance and helped shape the outcome of campaigns against transnational mining ( $\mathrm{Li} 2015,2016)$. In these cases, opposition to mining activity defies the dominant view of nature in which humans are the primary agents and rejects managerial and technocratic solutions embraced by mining companies and the state. These conflicts around mineral extraction do not only involve indigenous peoples; rather, they are about the defence of local worlds threatened by the aggressive expansion of extractive activity. As the chapters in this collection suggest, alternative world- and life-making projects are being formulated in South America that have the potential to challenge the politics of extractivism by destabilising established ideas about nature, indigeneity, and development.

In this chapter, we focus on some recent cases of resistance to mining activity in Peru's Northern Highlands, home to the country's largest gold mine. The Yanacocha mine, owned jointly by the US-based Newmont Corporation, the Peruvian company Buenaventura, and the World Bank's International Finance Corporation, has generated numerous conflicts with local communities since it began operating in 1992. In recent years, the mine's continued expansion and ongoing protests against the proposed Conga project have attracted widespread local and global attention. Grassroots opposition to mining results from a connection to local land- 
scapes as well as linkages to national and international NGOs, solidarity activists, the media, and other actors. In some cases, environmental campaigns and media representations of mining conflicts have evoked local ways of relating to a powerful landscape. However, the ways in which other-than-human elements of the landscape come into being and emerge as important political actors involve a confluence of different factors that cannot only be explained by 'tradition' or 'local knowledge'. At times, these forms of activism invoke indigenous identity, environmentalist discourses, and global justice. More generally, they enact different ways of knowing and being, attesting to the resilience of local worlds in spite of potentially destructive forces that encroach upon them. These emergent forms of activism and identity require theoretical approaches that recognise the existence of multiple worlds without essentialising or romanticising indigenous knowledge.

In the Brazilian context, some anthropologists (Goldman 2015; dos Anjos 2006) have called attention to counter-discourses that defy dominant ideas about mestizaje and syncretism and can work as guarantees against the homogenising pressures from the nation-state. These studies show how a group's self-identification comes from forms of creative expression, inventiveness, and characteristics derived from internal debate and reflection within the group itself. In the context of Cajamarca, people involved in mining conflicts have similarly sought to resignify concepts such as 'campesino' and 'indigenous', changing the meaning that has been attached to them by mining corporations, the state, and international institutions.

Our analysis of campaigns against the Conga project sheds light on the dynamics that shape grassroots activism as the testimonies of local leaders travel through documentaries, news media, lawsuits, and activist networks. We focus primarily on three women who have become spokespersons on an international stage: Máxima, Nélida, and María, three campesinas who have spoken out against the abuses of mining companies and in defence of Conga's lagoons. The first two are featured in the documentary La Hija de la Laguna (2015) and their stories have been shared around the globe, inspiring actions locally and internationally. We also consider the impact of the Conga case on solidarity activism, specifically focusing on María's role in bringing the Peruvian case to activism against resource extraction in Rio Grande do Sul, Brazil. We show the international reverberations of the Conga conflict and activist efforts by focusing on these three activists, highlighting the role of women in the 
conflicts. As Walsh (2017) has noted, it is no coincidence that women are often leaders in struggles against extractive activity. She cites Lourdes Huanca (a Peruvian peasant leader ${ }^{2}$ ) who links extractivism with 'the territories of our bodies'. According to Walsh, this invasion and violation of the body is felt due to the changes that these industries produce in social relations, social structures, and community dynamics (the rise in alcoholism, the encouragement of machismo, the mistreatment and sexual abuse of women, etc.).

A notable aspect of the campaigns against mining is the way women describe their opposition to mining activity in terms of their relationship to the land, their connection to place, and their identity. In some cases, gender is highlighted by activists or their interlocutors, and in others, their identity as campesinas or indigenous people is key. These identities facilitate the translations that take place as local experiences are made globally accessible. Postero and Fabricant (this volume) suggest that indigeneity (especially when combined with representations of gender) 'provides useful cultural and ethical material on which to base political and economic contestations, because its tropes are well known and malleable'. This malleability is crucial in the performance of indigeneity, which is expressed differently by various individuals and variously portrayed in media representations of them. In some cases, the depictions rely on simplistic explanations and romanticised representations of indigenous peoples. In others, they may challenge these stereotypical portrayals and provide new ways of talking about resource extraction.

As Descola (1998) and others have noted, many activist organisations derive inspiration from indigenous peoples, turning them into symbols of a harmonious relationship with nature. Concepts like 'mother earth' or 'the sacred forest' become generic representations of indigenous wisdom, even though these terms may not be equivalent to those used by indigenous groups. Collaborations between indigenous and nonindigenous activists have their limits, especially when certain local practices do not coincide with the sensibilities of foreign activists. In the cases we examine, for example, different conceptions of justice, 'spirituality', and 'earthbeings' may destabilise the premises on which solidarity efforts are built. This is where the role of women like Máxima, Nélida, and María becomes key, as they are able to move between worlds in order to share their message with diverse audiences. In this chapter, we examine what their stories reveal, what they conceal, and their potential to challenge the logic of extractivism by proposing alternative life-making projects. 


\section{'Environmental Heroes', Indigeneity, and Struggles Against Mining}

The Conga conflict erupted in July 2011, when the Yanacocha Mining Company officially announced its proposal to construct an open-pit copper-gold mine. The mine would be located at the head of the water basin for the provinces of Celendín, Cajamarca, and Hualgayoc and would require draining four lagoons (Perol, Azul, Mala, and Chica) to make way for the infrastructure of the mine. The company planned to construct four reservoirs to compensate for the loss of the lagoons. According to Yanacocha representatives, these reservoirs would store twice the amount of water that the lagoons regularly collect and would be distributed to communities so they could harvest one additional crop per year (de Althaus 2012). Water and lagoons have played a prominent role in campaigns against mineral extraction, and actions in their defence have sought to decelerate the aggressive expansion of extractivism in Latin America. The importance of Conga's lagoons stems from the relations that they embody, as well as campesinos' concerns with having access to the water that nourishes their land, crops, and families (Paredes Peñafiel 2016). These nourishing relations are sustained by campesinos' 'designs on the land' (Paredes Peñafiel and Li 2017), which encompass water resources such as streams and artisanal channels used for irrigation. The centrality of water in people's lives made the lagoons politically significant in struggles against the mine.

As the conflict attracted attention beyond the region, the lagoons also established connections between campesinos living near the project site and environmentalists, solidarity activists, international journalists, and other actors. The lagoons emphasised the dependence of local people on water resources while mobilising global concerns around biodiversity and the protection of a unique ecosystem. Within the diverse alliances that were formed to oppose the Conga project, people did not necessarily share a common stance on mining or environmental protection. As the Conga conflict gained notoriety beyond Cajamarca, various narratives incorporated the concepts of 'indigeneity' and 'nature' to express criticism towards Minera Yanacocha's operations. Drawing on the iconic images of three women (Nélida, Máxima, and María) associated with mining conflict in Cajamarca, we explore how these local actors and their national and international allies recast these discourses and practices in their struggles. 


\section{La Hija de la Laguna}

Activism related to mining activity has taken an international dimension in recent years, aided by extensive solidarity networks, social media, and global environmental and indigenous rights movements. Documentary filmmaking has also been an effective way of drawing international attention to mining conflicts. Nélida was 31 years old when she was featured as the protagonist of La Hija de la Laguna (The Daughter of the Lake), a 2015 documentary about the Yanacocha mine produced by Guarango, a Peruvian association of documentary filmmakers. Guarango had previously produced three films dealing with mining issues. ${ }^{3}$

The film synopsis for La Hija de La Laguna reads: 'At the height of the Peruvian gold rush, Nélida, a Peruvian woman able to communicate with water spirits, uses her powers to prevent a mining corporation from destroying the body of water she considers her mother' (daughterofthelake.pe). In promotional materials, Nélida is described as a peasant farmer and environmental leader with a love for the Cajamarca countryside. She also studies law in the city of Cajamarca in order to protect her community from corporate interests. The film emphasises her relationship with water and Mother Earth, ${ }^{4}$ imbuing it with a 'spiritual' quality (as it is popularly understood in Western conceptualisations of religion and spirituality): 'Like other indigenous citizens in the Andes, her relationship with nature is sacred and respectful' (La Hija de la Laguna 2015).

In the film, Nélida serves as both narrator and subject, a guide to the majestic landscapes threatened by mining expansion, and a fighter resolute in her stance against a powerful mining company. The documentary trailer begins with Nelida addressing Madre Agua (Mother Water): 'When they destroy the lagoons, where will their owners live, the spirits (duendes) of the lakes? Do they not understand that you are a living being?' Nélida's charisma comes in part from her ability to speak passionately and directly regardless of the audience or setting. She moves with ease from her native Porcón, a hamlet near the mine, to her life as a law student in the city, and more recently, to meetings with various national and international supporters.

In the year following the release of the documentary, Nélida travelled the world to promote the film and speak out against mining injustice. Her interviews - whether addressing farmers in Colombia or European journalists - evoked the sentience of nature and the need to respect and reconnect with the Pachamama. In an interview for a Spanish newspaper during a promotion tour of the documentary, she explains: 
The mountains are sacred for us Quechua. My grandfather ... taught me many things about the Andean cosmovision. What for you here might be just a mountain, for us has much meaning. An apu is sacred because it protects us. It protects us from the cold, it has natural medicines, it has wild animals. In order to enter a mountain, one has to ask for permission .... You have to take a fruit, or throw a little stone and ask for permission.

While Nélida refers to the $a p u$ as a mountain protector, this terminology is more commonly used in the Southern Andes and only gained currency following the Quilish protests in the early 2000s, another controversial expansion project of the Yanacocha Mining Company. The emergence of Quilish as an $a p u$ resulted from local practices and forms of relating to the environment, together with the intervention of NGOs, the media, activists, and environmentalists ( $\mathrm{Li} 2015$ ). As this and other examples have shown, grassroots activism defies the separation of nature and culture by emphasising people's connections to an agentive landscape (de la Cadena 2015; Kohn 2016). Nélida is part of this landscape and she is connected to it, but this is a landscape that is always in the making, acquiring new uses and meanings as it is transformed through extractive and other activities. She is also connected to her grandfather, who was an influential figure in her life and, like Nélida, was linked to NGOs and political networks. In the 2016 elections, Nélida ran as a candidate for Congress for the Frente Amplio, a coalition of parties that emerged in part from people's dissatisfaction with current policies of extractivism. Prior to that, she was involved with the local NGO Grufides, the organisation dealing most directly with mining issues in Cajamarca. Guarango's press materials identify Marco Arana, former priest and founding member of Grufides, as her mentor. Mr Arana won a seat in Congress and has become a divisive figure, but before his political career, he was most well known for his role in protests against Yanacocha. His involvement in disputes with the mining company began because of his close relationship with people in Porcón, where he was a Parish Priest in the early 1990s (when Minera Yanacocha first arrived in Cajamarca).

As a Catholic priest living alongside campesinos in the highlands, Marco Arana sought to understand and celebrate other ways of being and living in the world, including people's relationship with a powerful landscape. This relationship exceeded the state's definition of resources, but it also exceeded Mr Arana's own translations into the language of environmentalism and the sacred (Li 2015). Nélida's ways of expressing human-nonhuman relations 
should not be seen as simply a reflection of an indigenous cosmology and part of a traditional or peasant worldview. Rather, it exemplifies the coproduction of knowledge-influenced partly by local practices, indigenous practices from other parts of the country (such as the Southern Andes), and widespread discourses on indigeneity - in response to the threat of extractive activity. Rituals to honour the lagoons or the Pachamama are not only part of ancestral practices; they are changing forms of engagement with a landscape that is itself in the process of transformation. They are also a form of critique and resistance to an extractivist model of development built on the destruction of livelihoods.

Yet the way that mining issues are portrayed in the media and recent documentaries sometimes rely on simplified representations of nature and people's relationship with it. Our conversations with the director of $L a$ Hija de la Laguna, Ernersto (Tito) Cabellos, provided some insights into how decisions are made when filming a documentary and how these decisions in turn shape public opinion. In his telling, there were a few things that made Nélida stand out. Among them was her previous experience with a documentary, Yakumama (Mother Water) (Yakumama 2009). Her experience with filmmaking was an advantage, but there was another key reason: what he called the 'spiritual' aspect of her relationship with the environment. As his team began filming, they also realised that the lagoons became a powerful theme. He recalled: 'What impacted me-in addition to the activist component, the political mobilisation-was the spiritual dimension. It wasn't something that we had considered in our previous documentaries.' Tito was implying that Nélida's struggle was not simply an argument about the environment or human rights; it was about the Madre Tierra, which has become a prominent concept in the environmentalist vernacular in Peru and internationally (shorthand for a more complex and not always harmonious set of human-nonhuman relationships). His documentary was to focus on a young protagonist who could help us see the world otherwise. Tito's role was to relay what he interpreted as Nélida's message through images that he wove into a narrative. However, something that is not made visible in his translation of Nélida's world (or in her own statements to the media) is that duendes, spirits that inhabit the puquios (water springs), are not considered benevolent beings and are generally feared by campesinos in Cajamarca because they are said to take away the vitality of people who venture near them.

Tito said that, on screen, Nélida displayed strength but also a kind of 'fragility'-this comes from her realisation (and the viewers') that 'the conflict 
is much bigger than her' (Personal Communication). While the documentary plays up the usual trope of a powerful multinational against vulnerable (but courageous) individuals, Tito tried to introduce some complexity into the narrative with two other stories told in the film which also focus on female protagonists. In addition to the Yanacocha mine, he included the story of women working in a Bolivian mining cooperative. He was interested in the idea of portraying these indigenous, poor women who are also contaminating the earth but who have to do so in order to support their families. 'Are they good or bad?' he asked rhetorically. 'They have to help their families succeed.' Tito alluded to the ambiguity and contradictions in their lives, which he also shows in the third story of a jeweller from Holland that is interwoven into the film. The jeweller is torn between her art and her need to make a living from an industry that contaminates (but she is only just realising this as she visits the places where the materials she works with are mined).

If there is something tying these stories together, it is the connection between the past, present, and future of mining. The Bolivia story is about old-style mining that has existed and polluted the earth for centuries, while the Yanacocha sequences show the current (and expanding) operation of a so-called modern mine. But according to Tito, the scenes from Bolivia also represent 'the future that Nélida fears' meaning that the pollution and environmental destruction associated with older mines would be the legacy of mineral extraction in Cajamarca. The possibility of a 'clean' gold that could be used in the jewellery industry is a view to a less polluting industry, an alternative for the future. The director's efforts to show the nuance and complexity of people's lives are offset by the tendency to depict a more heroic narrative, as is often the case in documentaries about environmental conflicts. This heroic narrative downplays the divisions within communities, including people who support the project and those who have a more ambivalent position, one that may oscillate depending on their needs and the benefits that they can acquire from the company.

The documentary's story about the Peruvian Andes (focusing on the Yanacocha and Conga mines) shows the resolute opposition to mining embodied by Nélida and the film's other key protagonist, Máxima. At the time of filming, Máxima was a Peruvian peasant woman living on the land where the Yanacocha Mining Company wanted to develop the Conga mine. Máxima fought Yanacocha in court and received the support and admiration of people around the world for her valiant fight (as well as significant hostility from her detractors). Coincidentally, Máxima has been 
called the 'Lady of the Blue Lagoon' (Dama de la Laguna Azul was the title of a newspaper article by Miranda 2012), while Nélida (who was made into the titular 'daughter of the lake') does not reside near the lagoons but is shown in the film with Máxima. Nélida's community of Porcón is located downstream from the Yanacocha mine, near the city of Cajamarca, but these geographical referents and other contextual information are absent from the film, which shows both women together, interacting with the lagoons. When asked why he did not make Máxima the protagonist of the film, Tito responded that at the time he started filming, Máxima's case was not yet well known. But he also pointed out that her struggle was different: It is about property. This was not, to him, as compelling as Nelida's narrative, though it was nevertheless important to show. He felt that this particular story (about property) was the one that is usually told in the mainstream media, while Nelida's perspective (the poetic and 'spiritual' dimension of her struggle to defend the lagoons) was not given sufficient attention. In other words, Nélida's story makes clear that these struggles are not only about property, but the language of property is one that people like Máxima must rely on when presenting their case to the courts, the company, and the state.

\section{Máxima's Story}

Like Nélida's story, the case of Máxima Acuña illustrates the local and global dimensions of resistance to mining. Following the approval of the Conga project, Máxima refused to move from her plot of land at the site of the proposed mine. The mining company claims that it bought land from the community in 1996. Máxima insists that she purchased the land two years earlier from her husband's uncle and never gave up her rights to it. Máxima's house is located near the Laguna Azul, one of the lagoons that risks being turned into a toxic waste deposit if the mine is built. In an interview for the Spanish El Pais, Máxima is quoted as saying: 'I am poor and illiterate, but I know that our lagoons and our mountains are our true treasure, and I will fight so that the Conga project does not destroy them' (Ramírez 2015). Máxima and the Guardianes de las Lagunas say they are fighting first and foremost against the destruction of their sources of water. The Guardianes are campesinos and ronderos (members of the Rondas Campesinas or rural patrol), ${ }^{5}$ most of them from the centro poblado (hamlet) El Tambo, who have set up camp to protect the lagoons from the encroachment of mining activity. 
Since 2011, when the company built a road near her house, Máxima has faced a number of aggressions from company personnel. In May 2011, her small house was burnt down and her potato fields destroyed (Zárate 2015). In August, she and her family were confronted by the police and the mine's security guards, who tried to evict them and did not hesitate to use force against them. This aggression was documented with a cellular phone but denied by the company in court and in their statements to the press. To them, and to many of her enemies and detractors, Máxima was selfish and stubborn, squatting on land that did not belong to her, and preventing others from benefiting from the mining project.

The role of social media and international solidarity networks have been crucial for legitimising and raising awareness about Máxima's plight and have brought other women into the spotlight. A group of campesinas featured in documentaries such as Las Damas Azules (the Blue Ladies), by the Catalan Association of Engineers Without Borders, exposed the abuses committed against Máxima during vigils held at the San Francisco Church in the city of Cajamarca. These women also witnessed the actions taken by the company against Máxima when they accompanied her at her house in Tragadero Grande to lend their support. One of the women also acted in defence of Milton Sánchez, Secretary General of the Plataforma Institucional Celendina (PIC), when he was intimidated by the police during a march against the Conga project in 2014. After confronting the police, she was arrested along with some of her companions and taken to the police station in Cajamarca. When Milton Sánchez told this story, he affirmed: 'Hay Máximas aquí (There are [many] Máximas here). As we can see, 'Máxima' refers not to one person but became a symbol for the many women who defended their right to protest and denounced the state for not recognising this right.

Another woman who emerged as a prominent actor in Máxima's legal battles against Minera Yanacocha was Grufides lawyer Mirtha Vasquez, who became one of her closest allies. The courts initially found Máxima guilty of illegal land occupation, handing her a prison sentence of almost three years and a fine of USD 2000. Máxima appealed and in 2014, a higher court ruled in her favour and lifted the charges against her, a decision that was supported by the Supreme Court in spite of Minera Yanacocha's objections. Regardless of the court rulings, the company has continued its efforts to evict Máxima, through both intimation and force. But Máxima's struggle_-often described as a battle between David and Goliath-also attracted the support of people in Peru and internationally. 
An important moment in building alliances was when delegations from various countries arrived in Cajamarca for the First International Encounter of the Guardianes de las Lagunas in El Tambo. Held in the first week of August 2014, this event was attended by people from Colombia, Argentina, Spain (the Basque Country and Cataluña), Brazil, Chile, Mexico, and the Netherlands. Particularly noteworthy was the participation of delegates from France, among them the group Solidarité avec Cajamarca, AyneFrance, associations of Peruvians in France, and the French Senator Laurence Cohen. Also present were members of the NGO Grufides and the Plataforma Institucional Celendina, and Hugo Blanco, a well-known political figure and leader of the Confederación Campesina del Perú (Campesino Confederation of Peru).

In the evening programme the documentary The Guardians of the Lagoons (Los Guardianes y Guardianas de las Lagunas) was shown, along with a preview screening of the first part of La Hija de la Laguna, with the presence of members of Guarango. The French delegates also showed a documentary that told the stories of several campesinas active in the campaigns against Conga (e.g., La Ronderita Shilica). The construction of figures like Máxima and Nélida, as well as other female leaders, was influenced by the activists' intentional focus on gender, considered to be a crucial aspect of social justice work. Though it may be the case that the mining-development discourse tends to exclude women, it is necessary to also keep in mind the risks identified by Spivak (2010) and Abu-Lughod (2002) of 'Western' women constructing an image of the 'Third World woman' as lacking agency. However, in the documentaries mentioned, activists took special care not to 'speak for' the women but to let them tell their own stories and to be the protagonists of the films.

On the first day of the encounter, participants received the news that Máxima and her family had been ordered to vacate their land and pay 5000 soles for allegedly usurping Minera Yanacocha's property. The following day, as planned, event participants marched to the El Perol lagoon, passing by Máxima's house where people, including the French senator, expressed their solidarity with Máxima. ${ }^{6}$

Though her case is not an isolated one, Máxima has become a national and international icon of popular resistance to extractive industries. She has travelled to meet with activists in France and Belgium and, most recently, to the United States, where she was awarded the Goldman Environmental Prize in a ceremony in San Francisco. In lieu of an acceptance speech when receiving the prize, she sang a melancholy song that 
told of her hardships and her desire to protect the lagoons in the face of police and corporate aggression. Máxima's habit of using song seems to be inspired by her Evangelical faith (combined with a strong Andean lyrical tradition), and she usually sings religious hymns. Her Evangelical faith is not usually mentioned in media or activist accounts and is a significant difference from Nélida, who invokes her grandfather's teachings about what she calls the cosmovision andina ('Andean cosmovision', a term that has been popularised by the media and used by Nélida in her interviews with the press) and whose community of Porcón is traditionally Catholic.

Máxima's case has inspired comparisons with other women involved in environmental struggles, including the case of Bertha Cáceres, another Goldman Prize winner who was tragically killed in Honduras after speaking out against the construction of the Agua Zarca dam. But Máxima's story is also different in some respects: she does not consider herself an activist and is not a leader with previous experience. In one of the many news profiles written about her, Maxima's struggle is portrayed a personal one: 'Máxima Acuña explains that she only wants to preserve the only life she knows and that belongs to her: harvest potatoes, milk cows, knit blankets, drink water from the springs and fish for trout in the Laguna Azul without a guard telling her "that's private property"' (Zárate 2015). Máxima's struggle could be said to be about property and resources, but it is also more than this; it is about the defence of life that can only be made in place.

During a visit to her home in Tragadero Grande in September 2014, Máxima said to us: 'The land will shelter me until god takes me to heaven; is a van worth all of that?' This statement was reminiscent of other comments about Yanacocha's relationship with communities. For example, a Cajamarca-based teacher claimed that the kind of development encouraged by Yanacocha was intended to make it possible for everyone to acquire a Hilux (Toyota) van. The teacher, Nora, explained that the van corrupted the autonomy of the campesino: 'If [the van] breaks down, you have to take it to the mechanic. On our land, we plant, and if something happens, we plant again." This vision of life is based on people's relationship with the land (and water), and emphasises the need for campesinos to design their own life projects, to depend on others in a way that does not compromise their autonomy and to sustain their relationships with the human and nonhuman world. From the perspective of Máxima and Nora, the act of sowing is done in relationship with the land, which, as Máxima says, never abandons you (nunca desampara). ${ }^{8}$ 
Shortly before the announcement of the Goldman Prize winners, Newmont announced that it would not pursue the Conga project due to the 'current social and political environment' (Newmont Mining Corporation 2016). Among other considerations, the company acknowledged that local opposition was one of the factors leading to the decision (Jamasmie 2016). Welcoming the announcement, Máxima stated: 'The fact is our way of life, and the clean water we need to sustain it, is more important to us than Newmont's new gold mine ever could be. We know from Newmont's Yanacocha mine that, no matter their promises, we can't have both the mine and our way of life' (Earthworks 2016). Máxima's statements, unlike Nélida's, do not appeal to a sentient, agentive nature. It could be said that her ways of expressing her connection to the land are based on her everyday survival, which depends on having access to clean water. For her, mining is incompatible with her way of life-the two cannot coexist, but she refuses to accept that she must make way for extractive activity.

As an article in The Guardian notes, 'environmental activism was probably not what Máxima had in mind when she refused to sell her 60 acre plot of land' to the mining company (Collyns 2016). Yet Máxima's struggle is representative of new forms of activism that are shaping conflicts over extraction in Latin America. These forms of activism do not necessarily conform to the values or discourses of international environmental or indigenous movements but are sometimes embraced by them. In some cases, the global embrace of anti-mining campaigns by international media and solidarity activists can reinforce simplistic narratives about traditional knowledge and stereotypes of indigenous peoples. Simultaneously, however, activists are complicating these narratives with practices that challenge nature-culture binaries, break down divisions between local and global, and disrupt assumptions about indigeneity, local knowledge, and 'authenticity'.

\section{South-South Activism: La Hija de la Laguna and Rio Camaquã, Brazil}

In a recent Facebook post, the producers of the film La Hija de la Laguna showed the wide availability of the documentary, which, through the streaming service Netflix, has been made available in 190 countries. The opportunity to work with Netflix signified a major break for Guarango, giving the film much more attention than its earlier films. The documentary 
has also travelled in the film festival circuit and through academic and activist networks. We want to focus on one of the film's many journeys, to São Lourenço do Sul, Brazil, ${ }^{9}$ to show the international appeal of the film, its local uptake, and its impact on a mining conflict in the region.

Since 2016, professors and students from the São Lourenço do Sul campus of the Universidade Federal do Rio Grande (FURG) have been giving their support to the organisation Rio Camaquã-União pela Preservação (UPP). The UPP is made of residents, farmers, and teachers fighting against the development of a mining project to extract lead, zinc, and copper from Minas Camaquã in the district of Caçapava do Sul. This mining project, called Projeto Caçapava do Sul, ${ }^{10}$ is being proposed by the Votorantim Metals Holding (now Nexa Resources) and would be located $2.2 \mathrm{~km}$ from the Camaquã River in a reserve called bioma pampa (Pampa ecosystem) (Votorantim 2016). This river is a tributary of the Laguna de los Patos and provides water to São Lourenço do Sul and 27 other municipalities such as Caçapava do Sul, Cristal, Camaquã, Bagé, and Pinheiro Machado.

In 2016, a biology professor from the São Lourenço do Sul campus of the FURG noticed on Facebook a pronouncement by the UPP against the development of the mining project at Caçapava do Sul. Students and faculty members visited the municipality of Pinheiro Machado for one of the public hearings for the project's Environmental Impact Assessment (EIA). Some days prior, the faculty members had met to review the EIA, and they were prepared to provide an independent evaluation of the document and speak publicly against the approval of the project. It was also an important opportunity because it brought together members of the university and UPP representatives, primarily cattle ranchers from the municipality of Bagé.

Since 2016, family farmers, academics, and residents of the affected municipalities have organised to prevent the development of Votorantim's lead, zinc, and copper mine under the slogan Mineração, Aqui Não! (Mining, Not Here!) proposed by local organisations. The FURG professors supporting the struggle (primarily through the programme in Environmental Management) decided to organise a conference on the impacts of mining activity (Seminario Regional sobre os Impactos dos Projetos de Mineração) jointly with the Faculty Union to raise awareness about the problems in the southern part of their state. They also planned to invite activists from other Latin American countries, including Peru. Adriana Paredes Peñafiel (a faculty member at FURG) was also approached because of her previous research on the Conga conflict in Peru. She suggested inviting María-a female 'guardian' of the Mamacocha Lagoon in the area of the Conga Project and 
a rondera - who had been one of her primary collaborators during her fieldwork in El Tambo, Cajamarca. Since the organising committee did not know María personally, Adriana emailed them the link to the documentary Las Damas Azules (available online) so that they could acquaint themselves with her. Once they watched the film, they made the decision to invite María to participate in the conference. In this way, documentaries can serve to legitimise the struggle of grassroots activists and facilitated María's participation in the event. ${ }^{11}$

Also before the conference, La Hija de la Laguna was screened in São Lourenço do Sul, followed by a group discussion with professors, students, and activists. ${ }^{12}$ Since most people had not heard about Máxima's ordeals, they focused their attention on Nélida. Many of the students sympathised with the 'mysticism' of the Andes that they saw in Nélida's story (mainly when Nélida talks to La Duenda [water spirit]), but they made explicit that it was absent in the south of Brazil, where many people of European descent did not share the same relationship with water as was depicted in the film. This 'exotic' aspect defined the film's Andean protagonists for many viewers. Nevertheless, students in particular seemed to identify with Nélida, who is shown studying law as a way to help her community; the Brazilian students envisioned their own courses in Environmental Management as a means to work against the impacts of mega-development projects in their own country. ${ }^{13}$

On the day of the conference, María was invited to speak as part of a panel about her experiences fighting against the Conga project in Cajamarca. She presented herself as 'indigenous' (a term that she previously did not use) and as 'daughter of the land of the Collemarcas'. Performing indigeneity in these ways may help generate 'authority for making claims on institutions and forging alliances' (Pratt 2010: 402), lending credence to her story and helping to forge commonalities with other communities affected by extraction. María then sang, as Máxima has done in public events. Alvira Briñez (2017), who also writes about María and Máxima, explains that songs and poems are more than artistic forms of expression. Inspired by Walsh (2017), the author calls them 'estheticpedagogical practices', which are described as feelings and thoughts that resonate with the ways of life of campesinos because they come from lived experience. In order to be shared and understood by others, the recipients of the messages have to feel/experience too. María concluded her intervention by saying: 'I will fight until the last cartridge has been fired' ( voy a luchar hasta quemar el ulltimo cartucho). ${ }^{14}$ These last phrases had a strong 


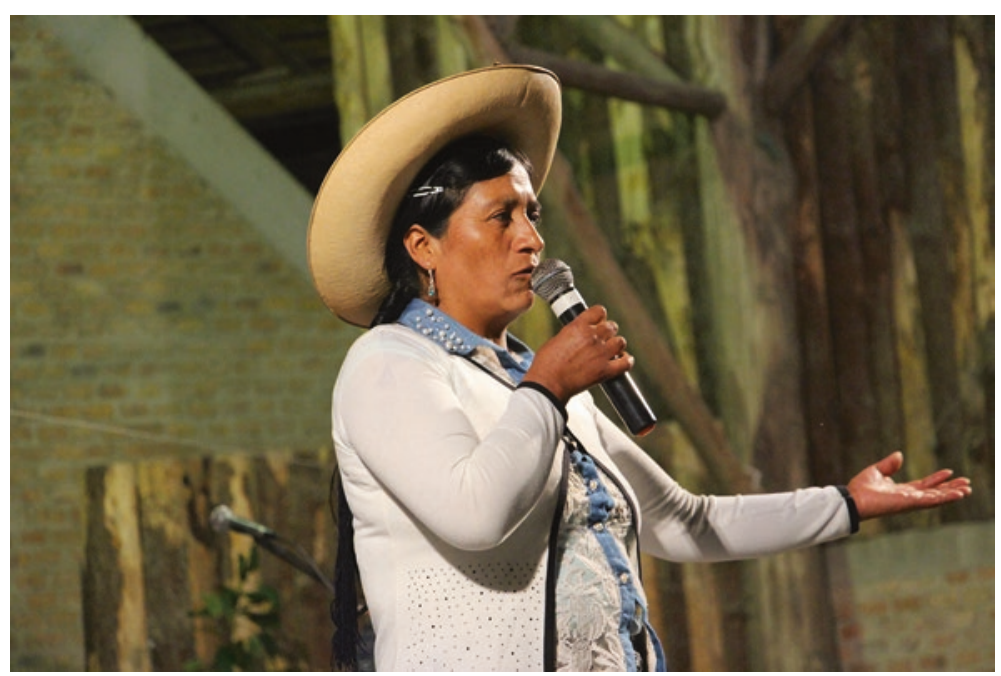

Fig. 9.1 María singing, São Lourenço do Sul, Brazil. (Photograph: Sedufsm, 2017)

impact on the families who had been impacted by the mining project, who said that they, too, like María, would resist 'even if blood must be shed'.

According to one of the students in attendance, María's story was the subject of much discussion among the audience members: 'She spoke from memory, she wasn't trying to please anyone, she just told her story.' Her song, the strong feelings that it evoked, and the energy she transmitted reminded them of Nélida. 'She's wonderful, strong.... I feel her strength when I'm by her side', the student commented (Fig. 9.1).

The events during the conference show how people create new connections and reflections based on the images and stories that activist networks present them. The images transmitted through documentaries and social media are powerful: the Yanacocha mine transforming the landscape, the women fighting for their land, Father Arana being dragged away by the police, the water march, and other images resonated with activists from the UPP and other residents of traditional communities who attended the conference. Invited Brazilian activists of the UPP spoke about childhood memories and oral stories of their ancestors: the gauchos who inhabited the Pampas. They wrote poems inspired by the River Camaquã, like the 'Prayer for a clean Camaquã River' (Oração de um rio Camaquã limpo), that opens an online petition against the mining project: 
Oh! Your man,

Above law and order

In this your lack of consciousness

You want to kill your beloved home

Without the children agreeing

But, too late, you will understand

Even if you are not alone,

Even with your gold dust,

To simple dust you will return.

(Diogo Corrêa, member of the UPP)
Oh! Tu homem...

Acima da lei e a ordem, nesta a tua inconsciência

queres matar a querência, sem que seus filhos concordem, Porém, tardio, entenderás, que mesmo não estando só, por mais que teu ouro em pó, ao simples pó, voltarás...

The Brazilian activists did not talk about the bioma pampa that was threatened by the mining project as 'nature' in the sense of being separate from culture, according to a dualist modern ontology (see Descola 2013). Rather, they talked about their relation to place, the importance of the River Camaquã, and the need to protect it at all cost. This brings to mind the testimony of a teacher from the Cajamarca city region, Nora, who spoke of her memories of playing in the Maschcón River (in the vicinity of the Yanacocha mine). Nora recounted that people avoided going near the river in fear of getting sick: 'My family is from here, we cohabited with the Río Maschcón when it had life, frogs, cobras. Since the arrival of the mine (Yanacocha), there is no life, now it only brings allergies. Now my nephew can't play in the river and he doesn't even believe that the river once had life' (Paredes Peñafiel 2016: 188). Nora alleged that her older nephews at least have memories of playing in the river, but the younger ones have not had these experiences. These relationships to the land create a sense of place and of belonging to that place.

How do people interpret stories about experiences that have touched them personally? One of the audience members in the conference at the FURG commented that, when he arrived on the first day, he heard María sing, and that singing was fundamental to social movement organising because there is feeling in these struggles. A student also noted that María's song communicated with the audience through feeling, something that would escape those who only want to understand through reason. It is through this emotive dimension that the Brazilian activists and people who are also victims of mining projects could connect with Nélida, Máxima, and María and recognise their common struggle for the defence of place. 
Documentaries, conferences, and other activist spaces of exchange provoke sympathies (maybe what de Castro would call 'uncontrolled equivocations ${ }^{15}$ ) that allow these environmental heroes to travel around the world. However, these exchanges can also produce friction and disagreement. During María's stay in São Lourenço do Sul, she was invited to speak to university students and professors about the role of the Rondas Campesinas. María spoke eloquently about the 'traditional customs' of the rondas, including the discipline that they administer as a form of justice and that sometimes involves physical punishment, depending on the crimes or infractions committed. This aspect of rondas justice caused some controversy in the classroom. The rejection of these practices was evident when the professors, in future events that made mention of María's visit to Brazil, limited themselves to describing the Rondas Campesinas in terms of their role as 'guardians of the lagoons'.

The stories told by María, Nélida, and Máxima are translated and transformed as they are discussed in political and academic spaces. These women do not speak the language of the audience, but their stories-and, perhaps most powerfully, their songs - are forms of expression that the audience (at least, those who are open to it) could take seriously. Alvira Briñez (2017) explains that aesthetic-pedagogical practices have different roles and objectives (pedagogical, self-recognition, form of expression, political, among others) and one of them is to transmit meaning to others.

After the seminar, María sang to the lake (lagoa dos Patos) that is threatened by the Votorantim company and her video (posted on Facebook) was presented at another conference to show that there are other relationships with water and that Brazilians can learn from them. Adriana was invited to 'explain' the video and discussed it with other invited traditional communities. The organiser wanted to know about the 'religiosity' of Andean people and their relationship with water in order to teach the students why people are against mining. At the event, an indigenous Paxató leader responded to the video by explaining that nature has an 'owner,' and when someone wants to take something without asking for permission, there are consequences. Various audience members translated María's relationship with the lake from their own perspective, adapting it to their own struggles but nevertheless extending María's original message and the voices of other women leaders whose stories have reached a global audience. As the anthropologist Luisa Elvira Belaunde told us when she listened to the songs of María ${ }^{16}$ : 'Lots of Peruvians are not interested in listening to these songs, but the soul of the lakes sing within them.' 


\section{CONCLUSION}

Recent conflicts in Peru have attained unprecedented international media exposure, forcing companies and the state into the spotlight and galvanising those opposed to mining expansion. Campaigns against Conga and other extraction projects have had a significant impact on local, national, and global debates around extractive activity, demonstrating the transformative nature of grassroots activism and its capacity to reinvigorate environmental politics. As we have seen from the cases discussed, resistance against extractive activity does not only involve indigenous people. As de la Cadena (2015) notes: 'Among other demands, local worlds-labeled indigenous or not-defy the monopoly of modern practices in making, inhabiting and defining nature.' Regardless of their various iterations, these local worlds defy the dominant view of nature that sees humans as the principal agents and proposes technocratic solutions like building reservoirs to replace natural lagoons. Yet international coverage of mining conflicts often presents communities and activists as indigenous, even though they might not necessarily identify as such. These representations of indigeneity may be problematic, in that they perpetuate the romantic ideal of indigenous people being environmental stewards of the land, ignoring the diversity of opinions about mining development that often divides communities.

In spite of the elements of romaniticisation displayed in La Hija de la Laguna and other documentaries, their impact and potential to inspire activism is also evident. According to one professor who participated in the Brazilian conference on mining: 'Perhaps the tools we use in the struggle are different (in the Andes, there are popular movements, and here we try to stop the mining project by finding errors in the Environmental Impact Assessment). Nevertheless, La Hija de la Laguna has shown us that the modus operandi of the company is similar to what is happening here, and that what is happening to the campesinos in Peru is like what is happening with our traditional peoples in Brazil-fishermen, small rural producers, all those who are ignored in the process.' The Conga conflict resonated with the Brazilian situation in spite of the differences involved and the particular lens of the spokespersons (whether filmmakers, activists, or campesinas) who transmitted their accounts of the events.

The stories of Máxima, Nélida, and María have some similarities. The three women defy the classifications and positions of subalternity assigned to them by the state and Peruvian society. Máxima refused to sell her land, as did the rest of the families in her community, challenging the logic of capitalism. At the same time, each of these women needs to know other 
languages and worlds in order to reclaim their rights. Máxima has done this through legal channels, alongside her lawyer and ally Mirtha Vasquez, and in the process gained the support of environmentalists. In Nélida's case, connecting worlds means speaking about 'water spirits' to international audiences and also studying law as a way of working for justice. Meanwhile, María transmits her feelings and captivates her audience through songs that tell of her struggles as a rondera and campesina, while also expressing the suffering of the lagoons. The three are able to move between worlds, and doing so allows them to make themselves understood.

Nélida, Máxima, and María have been involved in struggles over mining and engage with local worlds in ways that challenge the definition of nature proposed by the mining company and the state, even if they do so in different ways. This difference is not simply one between 'spirituality' and 'property', since neither term fully captures the relationship that they have with the land or with the various local and international actors entwined in their struggles. Rather, they are alternative life-making projects that are inspiring activists in the global North and South. Stories of local resistance take form, travel, and are rescripted along the way by participants, journalists and filmmakers, solidarity activists, and their various audiences. Their effects can be unpredictable, unintended, and farreaching. By destabilising established ideas about nature, indigeneity, and development, these life-making projects (amplified for a global audience) may pose a growing challenge to the politics of extractivism.

\section{Notes}

1. Established in 1989 by San Francisco philanthropists Richard and Rhonda Goldman, the prize is presented each year to six people representing each of the world's inhabited continental regions (goldmanprize.org).

2. Huanca is part of the FENUCARUNAP, the National Federation of Peasant, Artisan, Indigenous, Native, and Working Women of Peru.

3. La Hija de la Laguna marks a shift in style from these earlier films on mining. This may be due in part to the departure of Stephanie Boyd, the earlier films' codirector and coproducer, leaving Ernesto Cabellos in charge of the direction of the most recent film.

4. While the meaning and usage of Pachamama, Madre Tierra, or mother earth changes over time and in different contexts (from new-age spirituality to ecotourism), these terms have been adopted in recent political struggles to include environmental justice, indigenous autonomy and the defence of worlds, and the rights of nature within a biocentric worldview (Walsh 2017). 
5. According to Gitlitz (2013), the rondas from Cajamarca emerged in 1976 as a communal response to cattle rustling, theft, and sexual assault. With the passing of time, the rondas' system of justice dealt with other types of problems, including the circulation of rumours, disagreements between neighbours, disputes over inheritance, property rights, and even sorcery. Today, the defence of the lagoons and other sources of water has also come to be part of some ronderos' duties.

6. Another action in support of Máxima, with the help of social media, was a call for photographs of people holding signs that read 'solidarity with Máxima'. This action was spearheaded by a European woman who was active with a Celendín-based organisation and took place during the court case brought against Máxima by Minera Yanacocha. Máxima was ultimately absolved of the charge of illegal land appropriation.

7. According to Walsh (2017: 40): 'to sow is an insurgent act'.

8. This relationship could also be seen in the chapter by Stensrud (this volume), who discusses the meaning of ownership that involves diplomatic pacts (like pagos a la tierra) between people and earth-beings that are ignored by the state and its project of development.

9. This is a municipality in the southern part of the state of Rio Grande do Sul, with a population of 44,561 people (IBGE 2017) and a diversity of traditional communities such as the quilombolas, fishers, cattle ranchers, the cigano people, the pomerano, indigenous collectives, and others who cohabit around the Laguna de los Patos (Los Patos Lagoon) (Mazurana et al. 2016).

10. The project will consist of three open-pit mines and a beneficiation plant. The life of a mine is expected to be 20 years and it is estimated to start in 2019. The goal is to achieve a production of 36,000 tonnes of lead, 16,000 tonnes of contained zinc, and 5000 tonnes of contained copper, plus a small amount of silver, per year.

11. More than legitimising the struggles they depict, documentaries like those on mining conflicts are part of what the anthropologist Albert (Kopenawa and Albert 2015) identifies as an ethnographical pact that entails mutual obligations between the researchers and their interlocutors. People accept being objectivised if researchers (or in this case, filmmakers) adequately represent their struggles to the same society that violate their rights (see Viveiros de Castro 2015).

12. La Hija de la Laguna became available on Netflix a few months before the conference. A FURG student saw the film and passed the information over Facebook to a member of the conference organising committee. She circulated the information over social media, with images of the $2012 \mathrm{Marcha}$ del Agua (Water March) in Peru. The conference organisers used a photograph of a mural in El Tambo (painted during the Conga conflict and taken by Adriana Paredes Peñafiel) for the poster and T-shirt for the event, along with a phrase from the documentary: 'Water belongs to the people, not to the 
mining companies' (translated into Portuguese as A agua é do Povo, referring to the traditional peoples opposed to the Caçapava do Sul mining project).

13. Another part of the film that seemed to resonate with the audience was archival footage showing Father Marco Arana (at the time a key activist in the conflicts against mining in Cajamarca) sitting in the main square of the city holding a protest sign when a group of policemen drag him away violently and arrest him. The screening of the film coincided with protests of the coup against ex-President Dilma in 2016, in which students and faculty members had participated. Against this political backdrop, the arrest and police treatment of Father Arana were much discussed and associated with the treatment of protestors in the marches that audience members had experienced. Clearly, the political context and lived experiences of the viewers of the film have a significant influence on the associations, meanings, and reflections that La Hija de la Laguna provoked.

14. A national slogan supposedly originating in the War of the Pacific (1879-1884).

15. Viveiros de Castro describes an uncontrolled equivocation as 'a type of communicative disjuncture where the interlocutors are not talking about the same thing, and do not know this' (2004: 9).

16. Personal communication. Belaunde's work focuses on the political dimensions of visual and performance arts.

\section{REFERENCES}

Abu-Lughod, Lila. 2002. Do Muslim Women Need Saving? Anthropological Reflections on Cultural Relativism and its Others. American Anthropologist 104 (3): 783-790.

Alvira Briñez, Yamile. 2017. El Lugar del Canto y la Oralidad como Prácticas Estético-Pedagógicas para la Reafirmación de la Vida y su Existencia en los Andes Cajamarquinos. In Pedagogías Decoloniales: Prácticas Insurgentes de Resistir, (Re) existir y (Re)vivir, ed. Catherine Walsh, vol. 2, 245-272. Quito: Abya-Yala.

Collyns, Dan. 2016. Goldman Prize Winner: I'll Never Be Defeated by the Mining Companies. The Guardian, April 19.

de Althaus, Jaime. 2012. Entrevista a Dario Zegarra (Gerente de responsabilidad social de Conga). [Interview]. https://www.youtube.com/watch?v=olfaJltf03g. Accessed 15 Feb 2013.

de la Cadena, Marisol. 2015. Uncommoning Nature. E-flux Journal, July/August. Descola, Philippe. 1998. Estrutura ou Sentimento: a Relação com o Animal na Amazônia. Mana 4 (1): 23-45.

-2013. Beyond Nature and Culture. Chicago: University of Chicago Press. dos Anjos, José Carlos Gomes. 2006. Território da Linha Cruzada: a Cosmopolítica Afro-Brasileira. Porto Alegre: UFRGS/Fundação Cultural Palmares. 
Earthworks. 2016. Peruvian Farmer Wins 2016 Goldman Environmental Prize for Fighting World's 2nd Largest Gold Miner to a Standstill. April 18. https:// www.earthworksaction.org/media/detail/peruvian_farmer_wins_2016_goldman_environmental_prize_for_fighting_worlds_2\#.V2NbuLxViko. Accessed 5 Mar 2018.

Gitlitz, John S. 2013. Administrando Justicia al Margen del Estado: Las Rondas Campesinas de Cajamarca. Lima: IEP (Instituto de Estudios Peruanos).

Goldman, Márcio. 2015. "Quinhentos Anos de Contato": por uma Teoria Etnográfica da (Contra)mestiçagem. Mana 21 (3): 641-659.

Instituto Brasileiro de Geografia e Estatística - IBGE. 2017. http://cidades.ibge. gov.br/xtras/perfil.php?codmun=431880. Accessed 16 Nov 2017.

Jamasmie, Cecilia. 2016. Community Opposition Forces Newmont to Abandon Conga Project in Peru. April 18. http://www.mining.com/community-opposition-forces-newmont-abandon-conga-project-peru/. Accessed 5 Mar 2018.

Kohn, Eduardo. 2016. "Ecopolitics." Theorizing the Contemporary. Cultural Anthropology, January 21. http://www.culanth.org/fieldsights/796-ecopolitics. Accessed 15 July 2017.

Kopenawa, David, and Bruce Albert. 2015. A Queda do Céu. Palavras de um Xamã Yanomami. São Paulo: Companhia das Letras.

La Hija de la Laguna. 2015. Dir. Ernesto Cabellos. Lima: Guarango Cine y Video.

Las Damas Azules. 2015. Dir. Bérengère Sarrazin. https://archive.org/details/ las-damas-azules-documental. Accessed 1 Sept 2017.

Li, Fabiana. 2015. Unearthing Conflict: Corporate Mining, Activism, and Expertise in Peru. Durham: Duke University Press.

- 2016. The Defeat of Pascua Lama. North American Congress on the Americas (NACLA). https://nacla.org/news/2016/03/09/defeat-pascualama. Accessed 5 Mar 2018.

Mazurana, Juliana, Jaqueline Evangelista Dias, and Lourdes Cardozo Laureano. 2016. Povos e Comunidades Tradicionais do Pampa. Porto Alegre: Fundação Luterana de Diaconia.

Miranda, Oscar. 2012. La Dama de la Laguna Azul. La República. http://larepublica.pe/30-12-2012/la-dama-de-la-laguna-azul. Accessed 1 Dec 2017.

Newmont Mining Corporation. 2016. Form 10-K. Washington, DC: United States Security and Exchange Commission. http://dllge852tjjqow.cloudfront.net/CIK-0001164727/050eb34a-9eba-4984-a379-7684dlab4d2e. pdf?noexit=true. Accessed 5 Mar 2018.

Paredes Peñafiel, Adriana P. 2016. Desenhos, Relações e Desenvolvimento: Conflitos em torno da Mineração na Região Andina de Cajamarca, Peru. PhD dissertation, Programa de Pós-graduação em Desenvolvimento Rural, Universidade Federal do Rio Grande do Sul, Porto Alegre.

Paredes Peñafiel, Adriana P., and Fabiana Li. 2017. Nourishing Relations: Controversy over the Conga Mining Project in Northern Peru. Ethnos. http:// www.tandfonline.com/doi/abs/10.1080/00141844.2017.1410490. Accessed 15 Feb 2018. 
Pratt, Mary Louise. 2010. Epílogo: la Indigeneidad Hoy. In Indigeneidades Contemporáneas: Cultura, Politica y Globalización, ed. Marisol de la Cadena and Orin Starn, 437-444. Lima: IEP (Instituto de Estudios Peruanos).

Ramírez, Sara Cuentas. 2015. Soy Pobre y Analfabeta, pero Lucharé por nuestras Montañas. El Pais, April 7. https://elpais.com/elpais/2015/03/17/planeta_ futuro/1426588446_691506.html. Accessed 5 Mar 2018.

Spivak, Gayatri Chakravorty. 2010. Pode o Subalterno Falar? Belo Horizonte: Editora UFMG.

Viveiros de Castro, Eduardo. 2015. O Recado da Mata (preface). In A Queda do Céu. Palavras de um Xamã Yanomami, ed. David Kopenawa and Bruce Albert, 11-41. São Paulo: Companhia das Letras.

- 2004. Perspectival Anthropology and the Method of Controlled Equivocation. Tipiti 2 (1): 3-22.

Votorantim. 2016. Projeto Caçapava do Sul: Empreendimento Polimetálico da Votorantim Metais Holding no Rio Grande do Sul, São Paulo.

Walsh, Catherine. ed. 2017. Pedagogias Decoloniales: Prácticas Insurgentes de Resistir, (Re)existir y (Re)vivir. Vol. 2. Quito: Abya-Yala.

Yakumama. 2009. YouTube Video, 7:39, Directed by Nélida Ayay, Posted by Documental Peruano, 2 September 2009. https://www.youtube.com/ watch?v=F6faKdWKtfY. Accessed 5 Mar 2018.

Zárate, Joseph. 2015. Máxima Acuña: La Dama de la Laguna Azul versus la Laguna Negra. Etiqueta Negra, April 24. http://etiquetanegra.com.pe/articulos/maxima-acuna-la-dama-de-la-laguna-azul-versus-la-laguna-negra. Accessed 15 Jan 2017.

Open Access This chapter is licensed under the terms of the Creative Commons Attribution 4.0 International License (http://creativecommons.org/licenses/ by $/ 4.0 /)$, which permits use, sharing, adaptation, distribution and reproduction in any medium or format, as long as you give appropriate credit to the original author(s) and the source, provide a link to the Creative Commons license and indicate if changes were made.

The images or other third party material in this chapter are included in the chapter's Creative Commons license, unless indicated otherwise in a credit line to the material. If material is not included in the chapter's Creative Commons license and your intended use is not permitted by statutory regulation or exceeds the permitted use, you will need to obtain permission directly from the copyright holder.

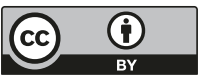




\title{
Performing Indigeneity in Bolivia: The Struggle Over the TIPNIS
}

\author{
Nicole Fabricant and Nancy Postero
}

\section{Introduction: Vigil For a ‘FaILED’ Event}

In 2012, the elected leaders of Bolivia's lowland indigenous organisation, CIDOB (Confederación de Pueblos Indígenas de Bolivia-Confederation of Bolivian Indigenous Peoples) staged a public vigil in the main plaza of the lowland capital of Santa Cruz, Bolivia. It was 9 August, the Day of Indigenous Peoples. The organisers had erected a big tent with photos of the recent marches CIDOB had organised to protest the government's proposed plan to build a highway through an indigenous territory and national park known as TIPNIS (Isiboro Sécure Indigenous Territory and National Park). Isiboro Sécure has been an important area for indigenous organising since 1990, when, responding to the demands of the first Indigenous March for Territory and Dignity, the president issued an

\footnotetext{
N. Fabricant $(\bowtie)$

Towson University, Towson, MD, USA

e-mail: nfabricant@towson.edu

N. Postero

University of California, San Diego, CA, USA

e-mail: npostero@ucsd.edu
}

(C) The Author(s) 2019

C. Vindal Ødegaard, J. J. Rivera Andía (eds.), Indigenous Life

Projects and Extractivism, Approaches to Social Inequality and

Difference, https://doi.org/10.1007/978-3-319-93435-8_10 
executive decree giving shared title to three groups of indigenous residents: the Tsimane, Yuracarés, and Trinitario-Mojeños. Then, in 2009, the area was given the designation of TCO (Tierra Comunitaria de Origen), a collective title under the agrarian reform law. The TIPNIS is now a 3869 square mile preserve, home to 63 communities, organised into two subcentrales. President Barrientos originally declared the TIPNIS a national park in 1965 .

The photos showed the 1200-kilometre journey that the lowlands community members and their highland allies had made the previous year to bring an end to the highway project, which had not been the subject of a prior consultation as required by the new 2009 constitution. The TIPNIS project proved to be a lightning rod for national and international debates about extractivist development, pitting indigenous and environmental organisations against the government and transnational oil companies. While struggles between indigenous peoples and extractivist projects are common across Latin America, the TIPNIS controversy drew international attention because Evo Morales, Bolivia's first indigenous president and the leader of Bolivia's 'cultural, democratic revolution', pushed for the highway despite the opposition of some indigenous communities. CIDOB's 2011 march led to a temporary victory, but, in 2012, a followup march had fizzled out, without any agreement being reached with the government. The march's leaders returned empty handed to the lowlands, only to find the government had organised a takeover of their organisation's headquarters by a sector of indigenous people who allied themselves with the government. As we explain below, the TIPNIS debate sparked conflicts in an already divided indigenous movement between those opposed to the government's plan and, especially, its failure to consult those most impacted, and those who felt the highway would link their isolated communities to markets and educational opportunities. The state used a 'divide and conquer' strategy to fill CIDOB with its supporters. Locked out of their headquarters, Adolfo Chávez, CIDOB's elected president, and other officials from his organisation waited in the plaza, trying to arouse public support. On that August day, we sat on the park benches with friends from nearby Guaraní communities, who cried as they described the shocking takeover of CIDOB the week before. Chávez explained that the TIPNIS case represented a 'most notorious abuse of our rights'. 'Even though the laws establish with clarity that the government should respect the [TIPNIS] territory and national park, we are feeling the contempt this 
government-like no other government before-has for us, the indigenous people of the eastern lowlands, the Chaco, and the Amazon' (pers. comm. 9 August 2012).

In this moment of crisis, Adolfo and his staff did what they had often done in the past: frame their cause by performing representations of 'good' indigeneity, linking their defence of territory to images of nature. That morning, a few faithful CIDOB staff had assembled in the tent, using images that had proven so helpful in capturing national and international attention for the 2011 march. Glossy posters showed mothers carrying their children strapped to their backs in colourful fabrics. Long lines of peaceful marchers wearing T-shirts and flip-flops trudged up steep roads from the tropics into the freezing cold of the Andes Mountains carrying banners of the colourful patujú flower (Heliconia rostrata), a symbol of the tropical forest. To make their struggle for territory relatable to the urban mestizos whose support they were trying to gain, the organisers chose images of clearly recognisable indigenous people, motherhood, and 'nature'. Gesturing to large green plants she had placed around the tent, one CIDOB staffer said, 'this is to represent the nature we are fighting for'. Posters decrying government repression of the 2011 march accompanied T-shirts for sale bearing the slogan: 'For the dignity of all the Indigenous Peoples'.

In this chapter, we describe how the TIPNIS controversy was fought, in large part, through performances, with different groups-the government, lowland elite, feminist groups, and lowland indigenous organisations (at both the local community level and the national organisation level) - using images and symbols of indigeneity to support their demands. Indigeneity is a fundamental site of politics where disagreements about the nature of the state, national sovereignty, its political subjects, and its relationship to land get played out with high consequences. As we show, the TIPNIS conflict illuminated a deep divide in Bolivia about the value of nature. Indigenous actors, along with others, challenged capitalist notions of the land and its resources, calling on indigenous cosmovisions and repertoires to argue for the protection of indigenous territory. Some of our fellow contributors to this volume might theorise this contestation through the lens of a 'politics of nature' or draw on Viveiros de Castro's notion of 'controlled equivocation' (Viveiros de Castro 1998). While this can be a very productive exercise, our focus here is a different form of politics of nature. We examine, instead, the ways indigeneity stands in for a notion of nature in political struggles. We show how various actors perform 'the virtuous' or 'good' Indian in order to stake claims and defend 
their notions of nature. As the TIPNIS case shows, especially when combined with representations of gender, indigeneity provides useful cultural and ethical material on which to base political and economic contestations because its tropes are well known and malleable.

This chapter makes two main interventions into the questions of both indigeneity and performance. First, we suggest that indigeneity here serves as what Povinelli (2011), following Foucault, would call an 'ethical substance', a central site of moral reflection and conduct in a certain era or 'social world' (Povinelli 2011: 10). In each world, the 'ethical work' of the self is to be in proper relation to the ethical substance identified as central (ibid.: 15). For Bolivia, we argue, indigeneity acts as such an ethical substance, a prime site of social ordering and anxiety. Povinelli uses the term to refer to both the material substance, that is, the people and bodies defined as indigenous, as well as the concept and representations of indigeneity, all of which serve as a site of 'embodied potentiality', possibilities that become 'eventualised' (or not) in particular moments and arrangements of forces (ibid.: 16). Who counts as legitimately indigenous and what ethical work such evaluations entail has been the centre of Bolivian politics since the colonial era. It is especially so in the era of Morales, whose government claims to have enacted an emancipatory indigenous state benefitting Bolivia's poor and indigenous population, thus 'eventualising' the potentialities inherent in indigeneity. That is why the TIPNIS controversy became such a watershed moment for the Morales government: the government's ethical and political commitments to bettering the lives of all indigenous peoples came into question. We suggest that an analysis of the varied TIPNIS performances provides a critical lens onto the ways performance acts to shape social worlds, as actors articulate specific figurations of ethical substance.

Second, we inquire into the politics of performance, arguing that these debates over indigeneity are played out in particular organisations of power, with differentially distributed capacities and vulnerabilities. We describe how both the Bolivian state and CIDOB performed the good Indian. Yet, we show that the state uses its position of relative power to define what good means in this context. The Morales administration pits an imagined, pre-modern, passive (female) lowland indigenous figure against a modern, politically agentive (male) highland Aymara figure. In contrast, despite all its efforts to embody the good Indian, in 2012, CIDOB did not have sufficient political power to garner public support or force the state to accede to their demands. Meanwhile, other actors were 
able to use their performed versions of the good Indian to push their ethical political agendas, such as state development or gender equality. We argue that the interplay between gender and performances of indigeneity is a key site of politics in this case. How does performance help us theorise indigeneity as an ethical substance, at once semiotic and material, that distinct actors can claim access to and use for their own benefit? How can we evaluate performance as a political tool?

\section{Performances, Politics, and Ethical Substance}

Anthropology has taken up performance as a way to theorise the presentation of self (see Turner 1988). For example, Dwight Conquergood (1991) showed how individual performances give marginalised subjects (whether Latino youth gang members or Hmong immigrants in Wisconsin) the ability to invert power structures and rewrite dominant narratives. Similarly, Sarah Warren (2009) shows how urban Mapuche women in Argentina construct their indigenous identity through gendered performances involving 'authentic' clothing, jewellery, and language, risking reinforcing gender stereotypes for the possibility of enhanced ethnic visibility. But Sergio Huarcaya (2015) points to the distinction between Judith Butler's now famous 1988 concept of 'performativity', the construction of the subject by the reiteration of norms, and 'performance', 'bounded acts done by a subject who consciously performs'. He argues, and we agree, that indigeneity is 'both performed and performative' (ibid.: $809 \mathrm{ff})$. That is, as we show below, who and what constitutes 'indigenous' is constructed both through governmentality, that is, through norms emanating from both market logics and state discourses, as well as through individual and collective agentive performances.

We add to these anthropological approaches to performance by drawing from Elizabeth Povinelli's rich theorisation of what she calls 'ethical substance' (Povinelli 2011: 14ff). Povinelli does not use this term in relation to performance; instead, she uses it to analyse a form of liberal governmentality in which particular arrangements of tense, eventfulness, and ethical substance make distributions of life and death, endurance, and exhaustion seem practical and sensible. We find particularly useful her focus on the ways that societies come to define certain objects as central sites of moral and ethical concern. What, she asks, is the material on which such ethical work is carried out in particular places and times? In settler colonial societies, indigenous peoples are understood and governed 
through discursive and linguistic strategies that place them in the genealogical past, as opposed to the modern agentive present and future inhabited by settlers. This 'governance of the prior' is enacted through forms of representation and language and lived and embodied under differently structured material conditions (ibid.). It is a site of discursive framing and governance, but it is also very much material, as the bodies, lives, and deaths of native peoples are the substance through which the ethical debates are carried out.

We consider indigeneity a key ethical substance, a central site by which life and death have been organised in colonial and postcolonial societies. Scholars have described the discursive and material means by which indigenous peoples have been constructed as objects, labour, and nonhumans (cf. Hall 1996). Indigenous territories have been occupied, their bodies tortured and massacred. Over the last decades, however, as indigenous peoples have organised and proposed alternatives to coloniality, capitalism, and liberalism, they have made visible the liberating 'potentialities' immanent in the ethical substance of indigeneity (Povinelli 2011: 12-14). A central part of the Morales revolution has been to bring indigenous peoples and their values, ethics, and practices to the centre of the nation and to use these ideals to reconstruct laws, practices of governance, and a constitution. This theoretical framing seems more relevant in the Bolivian context than, for instance, a Bourdieusian perspective that might see indigeneity as a form of symbolic capital. Rather, the Morales revolution has been an ethical project, used to draw attention to the founding violence of the Bolivian state and the continuing legacies of it. In essence, this aimed to challenge the ordering of society, enacted through the governance of the prior. Through laws, policies, and performance, Morales has linked his political and economic agenda of resource extractivism, what he calls 'economic liberation', to a particular form of indigeneity. As Andrew Canessa rightly puts it:

[i]n Morales's Bolivia, political legitimacy rests on being indigenous (although this is, of course, contested). On many occasions Morales has positioned the indigenous as being the best place from which to defend and protect the nation's resources and to push for social justice on a very wide front. Indigeneity provides his government with the legitimacy to rule and a platform from which to protect the nation against cultural and economic globalization (even as he embraces many of its key aspects); in short, indigeneity is the foundation of a new nationalism. (2014: 17-18) 
But, as Canessa points out, indigeneity is not a neutral or static notion; it is rather a constructed category that is under constant renovation and contestation. It is also relational. On the one hand, as Marisol de la Cadena and Orin Starn (2007) point out, 'indigenous cultural practices, institutions, and politics become such in articulation with what is not considered indigenous within the particular social formation in which they exist' (2007: 4). On the other hand, as Stuart Hall (1996) has shown, indigeneity has always been composed of opposing images: the noble savage versus the dangerous cannibal, the educable peasant farmer versus the radical revolutionary.

Charles Hale $(2002,2004)$ has argued that these dualities took a specific form in the neoliberal era. He showed how shifts in state ideology towards multiculturalism paired with aggressive neoliberal policies led to a new form of governance that reconstituted racial hierarchies in new forms (2004:16). The core of neoliberalism's 'cultural project', he argued, was 'the creation of subjects who govern themselves in accordance with the logic of capitalism' (ibid.: 17). As a result, using a term first formulated by Bolivian scholar Silvia Rivera Cusicanqui, Hale argues that this form of governance 'proactively creates and rewards' the Indio permitido (the authorised Indian) whose demands for rights do not challenge the state or global capital, while it condemns the 'undeserving, dysfunctional Other', the Indio probibido (the prohibited Indian) to 'racialized spaces of poverty and social exclusion' (ibid.: 19).

Hale's analysis clarified what scholars across Latin America were observing, giving us a vocabulary to describe the subject positions 'responsibilised' multicultural indigenous actors appeared to be inhabiting. It is important to recognise the specificity of the historical moment that Hale carefully traced: the indio permitido was a subject position produced during the neoliberal period in Latin America. Hale relied on a Foucaultian framework to explain the effects of a particular form of neoliberal governmentality. He described how non-state actors like nongovernmental organisations (NGOs) and international aid agencies encouraged or discouraged different kinds of conduct. One of the hallmarks of neoliberal governmentality is that it works through the 'techniques of the self', rewarding subjects who enact the appropriate behaviour themselves. Thus, Hale noted, in the neoliberal era, visibly repressive tactics were rare. Instead, neoliberal governmentality served 'the more reasonable proposition of nudging "radical" demands back inside the line dividing the authorized from the prohibited' (ibid.: 19). 
Our analysis of the performances during the TIPNIS case shows two important shifts in thinking about how the image of indio permitido has been articulated during the Morales era. First, while there have been numerous debates about whether the Morales regime is 'post-neoliberal' or rather an extension of neoliberalism (see Postero and Goodale 2013), we see here that the indio permitido continues to have purchase in a period where the state uses what Foucault would call its 'sovereign power' (Foucault 1991): direct state violence, legal sanctions, and economic cooptation. That is, notions of 'good' and 'bad' Indians continue to circulate in the narratives we recount here, but they are not only those emanating from a neoliberal logic, as Hale described. Instead, the Bolivian state uses these notions as a part of the tools of sovereignty to reinforce indigenous groups who cleave to the state line and support capitalist accumulation and extractive industries and to punish those who fail to acculturate to the workings of the market.

Second, rather than only being a site of self-government or a means to access government technologies of care, we show that indigeneity is also a fundamental site of politics where actors use performance to overtly contest what form of development is appropriate for local communities and who gets to decide. Thus, being a good Indian or bad Indian in the Morales era results in more than encouragement or abandonment; it is more than a cultural project. It is also a political project about development, extractivism, and sovereignty fought at the site of ethical substance. This has material implications: as we show below, being a bad Indian (in this case, resisting a particular form of development) can result in jail, organisational takeovers, violent physical repression, or the dispossession of territory. Thus, the agentive performances of indigeneity we document in this chapter are political acts of disagreement. Facing this mode of government, indigenous people, their allies, and the state all carry out politics through spectacle, protest, and performance.

Why are spectacle and cultural performance so important? Scholars have noted how ritual, drama, and carnival can offer a critique of the existing social system by presenting alternative forms of living and social ordering (Guss 2000; Mendoza 2000). Obviously, this is most clear in the spectacles of the state; it is through spectacle that national political communities are imagined, created, and communicated to subject-citizens (Anderson 1983; Joseph and Nugent 1994; Corrigan and Sayer 1985). But spectacles can also be tools for political protest, serving as a means for marginalised groups to thrust themselves into the public sphere 'through 
dramas of citizenship' (Holston and Appadurai 1999). There is a long history of social movements in Bolivia using the repertoire of embodied performance as a vehicle for structural change. These include hunger strikes against the dictatorship, highland Andean women blocking major roadways with their bodies, and the Landless Movements squatting on rural hacienda lands to protest inequities in land distribution. In the TIPNIS case, we describe here, multiple actors use such repertoires to debate not only the appropriate form of national development but also the fundamental political questions of who decides.

\section{Performances and State-Making in Bolivia}

Morales and his MAS (Movimiento Al Socialismo or Movement Towards Socialism) party came to power in 2005 by challenging the neoliberal policies of previous regimes and promising to redistribute the patrimony of the country to its poor and indigenous populations. This anti-neoliberal agenda was paired with a promise to 'decolonise' the Bolivian state, to overcome the structures and practices of racism against its majority indigenous population. Thus, Morales and the MAS were charged with bringing into being a new revolutionary state and institutionalising a 'process of change'.

As Farthing and Kohl (2013) note, the robust rural oral history traditions in Bolivia facilitate cross-generational transmission of past injustices, transforming storytelling into sites of political action. Morales has been particularly adept at using this repertoire, mobilising performances of indigeneity to play upon emotions of the disenfranchised masses-for whom indigeneity has become a sign indexing their oppression as well as a platform for claiming rights (see Canessa 2014). James Jasper (1998: 409 ) has urged social movement scholars to take emotions seriously, arguing that emotions and affective reactions are integral to building social movements. He suggests, in fact, that people are often recruited into movements after suffering what he calls 'moral shocks', leading them to channel their anger into righteous indignation and political activity. This brings our attention back to the question of ethical substance: we suggest that political performances draw upon emotional responses precisely because they impact deeply held ethical positions.

The Morales administration has tapped this deep well in many of its performances. For instance, Morales began his administration with a memorable inauguration ritual at the archaeological complex at Tiwanaku, 
where he was blessed and cleansed by Aymara spiritual leaders. There, invoking the Andean notion of pachakuti, or reversal of the world order, he declared the beginning of a new millennium of justice for indigenous peoples of the continent (Postero 2007). For every critical legislative reform, Morales rallies support through spectacular events mobilising indigenous history and tales of oppression and injustice. For instance, when Morales passed the New Agrarian Reform law in 2006, he organised social movement activists in the city of Peñas, the site of the brutal death of eighteenthcentury anti-colonial Aymara revolutionary Tupac Katari. Addressing thousands of peasant farmers, he declared: 'I stand before you today ... at the site where Julian Tupac Katari was descuartizado [quartered].... We are here to liberate our country, and Katari is the principal reference point for the indigenous struggles in Bolivia and a constant reminder of the obligation to decolonise Bolivia' (see La República 2006). Through these performance events, Morales embodies the spirit of Katari as the leader of a movement liberating the country from a colonialist and racist history. Here, we see the hegemonic redemption story of the new state, which promises to put the evil of colonialism in the past and lead the way to a future of justice (see Meister 2011). Gathering up past and contemporary struggles over land and territory, Morales makes his national project of decolonisation seem universal, incontestable, and deeply ethical.

A second important narrative that Morales embodies has to do with what Kohl and Farthing (2012) call 'resource nationalism'. In contrast to the long history of natural resource extraction-first by the Spanish conquistadors, then by white-mestizo elite, and finally by transnational corporations - the MAS state promises to construct a new form of justice based on redistribution of resource wealth to the indigenous and poor. This position has enormous emotional weight with Bolivia's poor, especially as it is combined with a strong system of public redistribution through bonos, or cash transfers (Postero 2013). During the MAS administration, the economy greatly improved (CEPAL 2012). As his definitive 2014 electoral victory showed, this has been an extremely effective tool of state formation; despite widespread criticism of Morales, peasants, labourers, and working classes rallied behind him.

As was clear from earlier examples, Morales initially argued that indigenous values could be mobilised to create radical changes like land reform, management of natural resources, and protection of Mother Earth. In recent speeches, however, Morales has argued that the country's goal is 'economic liberation' (Morsolin 2015). Elsewhere, we have argued that 
'economic liberation' has become a powerful new consensus in plurinational Bolivia, building on and replacing previous revolutionary discourses of indigeneity, decolonisation, and even global climate change (Postero and Fabricant in press; Postero 2017). In the MAS state's new vision, one version of indigeneity is now rearticulated as part of global capitalism under a new rubric of national sovereignty. Morales uses an ethical stance here as well, arguing that profits from extractivism will benefit indigenous communities as well as support national sovereignty.

\section{The TIPNIS Project}

It was within this context of development, extractivism, and economic liberation that TIPNIS exploded. In 2010, Morales announced a plan to build a highway linking the tropics of Cochabamba to the Brazilian border. The highway was to be funded by the Brazilian national development bank, opening new possibilities for trade with Brazil. The Morales government claimed that the highway would bring prosperity and trade to lowland peoples and help the state achieve control of the national territory. But the proposed highway would run through the Isiboro Sécure Indigenous Territory and National Park, both a forest preserve and TCO (communally held indigenous lands). Many residents feared that the road would bring ever-greater ecological destruction to a region already deeply affected by cattle ranching and illegal forestry. They were particularly concerned that it would open up their lands to further colonisation by Andean coca growers, who already inhabited one section of the park. Other local indigenous communities were pleased with the possibilities that the paved road might bring by linking them to bigger cities and markets and bringing increased access to education and healthcare systems. Here, we see national narratives of autonomy and sovereignty localised to indigenous communities. In his analysis of the TIPNIS case, John McNeish (2013) explained these opposing views by pointing to differing relationships with resource extraction: some indigenous communities are linked to the market in deeper and more positive ways than others, making them more likely to want more reliable access to markets for their goods and labour. However, it is clear that people's position in the labour and agricultural markets did not map perfectly onto their positions on the road. There were many other factors, including their own assessments of whether they and their families would be directly benefitted, the histories of clientelism in the community, the seasonal labour opportunities available, leaders' 
experiences in and loyalties to national indigenous organisations, NGO influences, marriages and friendships, and so forth (see McNeish and Arteaga Böhrt 2013). Building on McNeish, Anna Laing (2015) argued that the contrasting ideas about territory, rights, and nature that emerged on the marches reflected competing demands for resource sovereignty. Who should benefit from the resources of the territory, and, more importantly, who should decide? How to balance between protecting 'nature' and benefitting from 'development'? As a result of these difficult tensions, Cecilie Hirsch (2012) argues, leaders were forced to make difficult pragmatic decisions to bring resources to their communities, despite their overarching concerns for the sustainability of the forest.

Even among those who opposed the highway, few were opposed to development, in general, or even the construction of a highway. Marilín Karayuri, a Guaraní journalist who worked as part of the communications committee of the march, told us that the marchers were mostly concerned that they had not been consulted about the placement of the road or the potential damages to the environment. When the project was announced in 2011 , instead of carrying out the constitutionally mandated right to be consulted about development projects that might impact them, President Morales notoriously declared 'Like it or not, we will construct this highway' (La Jornada 2011). Thus, says Karayuri, the TIPNIS struggle represented a much larger concern than the highway. 'If they could enter in this territory that was titled by the government, and a national park, they could enter into any indigenous territory. So TIPNIS signified the gateway to all indigenous territories' (pers. comm. I1 July 2016). This was critical because many lowland indigenous communities saw this government as once again sacrificing them and their territories for 'national' development, the benefits of which they would not reap. This was the crux of the issue, as lowland communities saw the state's actions as undermining the state's ethical responsibility to protect indigenous lands and territories, not open up more veins to world market extractivism. To register their opposition, especially to the lack of consultation, the CIDOB and the National Council of Ayllus and Markas of Qullasuyu (CONAMAQ) mounted two nonviolent marches.

The first, in 2011, captured international attention when the national police intervened in the small town of Chaparina, teargasing and firing rubber bullets at the protestors, including women and children. This changed the public debate substantially, and when the march finally arrived 
in La Paz, the centre of Morales' political support, it received a warm and massive welcome. Morales was forced to declare the park intangible, or untouchable, and to carry out an ex post facto 'prior' consultation. Some communities were satisfied with the results of the march and the government's 'concessions'. But others were not, and some even suggested that the declaration of intangible was actually a form of spiteful punishment by the Morales state, a kind of bad-faith invocation of ideals of environmental protection and sovereignty, to show that the TIPNIS activists were so extreme as to oppose all development. Here, we see how the state continuously marked the marchers as indios prohibidos. Then, amid dissent within regional and national indigenous groups, in 2012, CIDOB mounted a second march to protest the last-minute consultation process, arguing that MAS had co-opted many indigenous leaders and set up parallel organisations to support the government. Again, this was an ethical challenge to the state, arguing that it had violated the ethics of participatory democracy and collective indigenous decision-making. The 2012 march received much less public attention than the previous year, in part, because the lowland organisations were split on whether marching again was a good idea. When they did reach La Paz, they were unable to negotiate with the government and returned home empty handed to the lowlands. As we showed in the opening scene, they were left to perform their virtuous indigeneity to residents passing through the central plaza in Santa Cruz, hoping for support from the mestizo elite. In part, this appeal set up a familiar narrative of victim and protector, where the mestizo elite, known as cambas, could play a role of 'defender' against Aymara colonisers writ large. It appealed to the elite desires for territorial control of the lowlands, a space that they imagined as having been invaded in recent years by Aymara and Quechua migrants. Claiming historic rights to this territory and to native peoples of their region allowed the lowland elite to make a call for regional autonomy, which they portrayed as a matter of justice. Despite these appeals, however, the government subsequently claimed the consultation with the TIPNIS communities showed substantial approval of the highway, and, after a temporary postponement, announced in 2014 that the highway project was still in the works and likely to resume shortly (Achtenberg 2014). In 2017, the conflict returned to public attention, as Morales announced plans to lift the moratorium and begin construction (EjuTV 2017). 


\section{Public Discourses and Performances During The TIPNIS Controversy}

So, how did the Morales government use indigeneity and performance during the TIPNIS crisis? First, it is important to note that, like all states, the MAS-led state is not a homogenous entity with one single vision or set of tactics. As we carried out fieldwork in 2012, 2014, and 2016, we conducted participant observation in the city of Santa Cruz and spent time inside spaces of indigenous organising. We interviewed local and regional indigenous leaders, as well as public officials in cities, department, and national offices. We both focus on Santa Cruz, but we also spent time in La Paz, the capital, as well as smaller cities like Charagua, in the southeastern zone. We found an enormous range of opinions within the state apparatus about the TIPNIS case. We heard dissent even from MAS militants working in state ministries, especially those indigenous intellectuals who had been delegates to the Constituent Assembly and had worked closely with lowland indigenous organisations there. One indigenous leader literally backed out of the room when we asked her about it. The Minister of Defense, Cecilia Chacón, renounced her position after the Chaparina violence, and the National Ombudsperson issued a harsh critique of it (Defensor del Pueblo 2011). Yet Morales and his closest advisers put forth a united front defending the road. In a controversial 2013 book, VicePresident Álvaro García Linera argued that the highway would protect lowland peoples from rapacious patrimonial-hacienda elite and foreign corporations that currently control the region. To break up their power, he said, the MAS state should regain territorial control over the region in order to provide for the greater good. This then became a strategy of defending this resource-rich region from foreigners and NGOs. 'In the Amazon, then, it is not the indigenous peoples who have taken control of the territorial power, as occurred years ago in the highlands and valleys.... But it is the despotic landowner order that predominates the region and has controlled indigenous organisation' (García Linera 2013: 8; see Beaulieu and Postero 2013).

In this quote, we can see echoes of Hale's indio permitido, as García Linera invoked a discourse labelling one set of indigenous peoples as good Indians and others as bad Indians. On the one hand, Morales frequently refers to the highland Aymara or Quechua people when describing the country's modern development agenda. The new Aymara middle and upper-middle class emerging in $\mathrm{La} \mathrm{Paz}$ as a result of their transnational 
trade with China are especially lauded. This is not an anti-capitalist discourse but rather a discourse from within the global capitalist framework. As Emily Achtenberg states, 'it has been clear that the MAS has [transitioned] from a government of social movements to a big tent hegemonic power consolidated around a pro-growth, extractivist, neodevelopmentalist agenda cast in national-popular terms' (Achtenberg 2016: 374). Highprofile megaprojects that evoke national pride, like the spectacular aerial cable car between La Paz and El Alto and the Tupac Katari satellite that brings internet to schoolchildren, all represent new and dominant symbols of a modern progressive nation. These shining new initiatives stand in stark contrast to the ways the TIPNIS protestors were represented as living in the past and resisting progress. The lowland indigenous figure is frozen in a pre-modern state while the Aymara becomes sign and symbol of modernity and progress within a capitalist system of extractivism and development. National peasant union leader Roberto Coraite suggested that the TIPNIS protesters should choose between the road, which would bring them trade and development, or else 'stay in clandestinity, as indigents, remaining as savages' (La Prensa 2011).

The good-bad narrative is further cemented through representations of gender. For instance, speaking to his highland supporters in the cocagrowing area in 2011, Morales famously urged them to seduce the women of the TIPNIS to gain support for the highway (Mendoza 2011). Here, we see the trope of the passive lowland indigenous woman waiting to be penetrated by the active masculine outsiders. Again, this contrasts with images the government puts forward of the militant Aymara and Quechua women insurgents, such as eighteenth-century anti-colonial leaders Bartolina Sisa and Juana Apaza, as well as the more contemporary images of Aymara women blocking roads during critical moments of antineoliberal protests (see also the chapter by Li and Paredes Peñafiel, this volume). The image of Andean masculine power echoes in the many artistic posters that circulated online and papered the country's walls during the controversy, showing the highway as a phallic symbol, slicing open, and raping the forest (See Beaulieu 2014b). One popular image shows Morales wielding a phallic-shaped chainsaw cutting down a tree. The overarching message of these images is clear: the road is a violent and gendered form of penetration. Such gendered discourses of control through rape, violence, and conquest of lands harken back to the colonial forms of patriarchal oppression that scholars have so ably described (see Stephenson 1999; Weismantel 2001; Canessa 2005). While many of these images 
came from critics of the road, they reinforced the gendered representations that put lowland indigenous peoples in a subordinate role ultimately pacified and controlled by the phallic Andean state, which will lead the nation into modernity and progress. In this view, national sovereignty is tied to Andean control and subsequently the submission of lowland indigenous lands, territories, and bodies.

\section{Lowland Narratives: The Figure of the Suffering INDIGENOUS}

During the struggles over TIPNIS, the MAS government was in a privileged position to articulate its stance through many public performances. Yet, the TIPNIS activists were able to present their own narratives as a result of the massive media attention the case received. They were able to use symbols and spectacular protest as productive forms of resistance to the Morales state, legitimising the ethical position of the lowlands peoples. We now turn to their efforts, demonstrating how they used many of the same symbolic elements to construct very different representations. Again, we want to emphasise the multiplicity of actors and perspectives that abounded in lowland communities. Yet, examining the semiotics of performance, we see that this multiplicity was reduced to produce a figure of a noble group of good Indians bravely resisting the state and defending the environment.

In 2011, the leaders of the TIPNIS march uploaded a video on YouTube called 'Message from TIPNIS to the World'. In it, Justa Cabrera, a Guaraní woman from Santa Cruz, and the president of CNAMIB (Confederación Nacional de Mujeres Indígenas de Bolivia), the women's organisation within $\mathrm{CIDOB}$, described the struggle this way:

TIPNIS is our home and our life. We the indigenous people live, hunt, and fish, our life is based on the contact with nature. And so we demand that our government respect our cosmovision and our life... TIPNIS is the lung of the forest that serves the Bolivian people, and Latin Americans and the world. (Cabrera and Poiché 2011)

These declarations, echoed over and over by TIPNIS spokespeople, obviously fit into the wider discourses used by activists and the media to represent indigenous people as ontologically different, as holding a special and authentic understanding of the universe, a 'cosmovision'. It is tempting 
to see Doña Justa's words this way, but it is also important to see the political context in which these clichéd phrases were uttered. This was a mediadriven video that was immediately put up on YouTube to attract attention and sympathy for the march. This is not to say that the declarations are not true or that Doña Justa does not believe them. Instead, as Michael Cepek has argued, it is critical to recognise such statements not as evidence of fundamental alterity but as provisional distillations of complex and multiple epistemological positions (Cepek 2016: 633).

Throughout the march, declarations like Doña Justa's were augmented by an array of symbols and images. When the organisers were planning the 2011 march, the communication committee strove to find symbols to give it a coherent image. These symbols become part of what Dell Hymes (1981: 79) called a 'communicative repertoire' that helped to give meaning to the social interactions between the marchers and an audience that include both the Morales state and civil society. The obvious choice for TIPNIS protestors was the patuju flower, one of two national flowers of Bolivia (along with the Andean kantuta). Although both the central and the state governments had used the patuju flower in their performances (see Vice-President García Linera's (2014) book, where an image of the highland flag, the wiphala, is superimposed on each petal of the pataju flower), the CIDOB organisers decided it would be the best symbol, along with the arrow, a well-known sign of lowland indigeneity. Marilin Karayuri says they chose the patuju flower because it is red, green, and yellow, the colours of the Bolivian flag, but more importantly, because it grows in all the indigenous territories. It was an important symbol of indigeneity and the territory they were trying to conserve.

The territory has always been our home and that is what we have to defend. And so, this is what we discussed in the preparation for the march, the theme of the conservation of life, not just of our lives but also of nature's life. Ultimately, we are one, nature and the indigenous people, along with other human beings. Because the protection of the environment has always been in our hands. (pers. comm. July 2016)

As Laing (2015) and Kaijser (2014) have also shown, the association between indigenous peoples and nature reinforces the trope of the virtuous eco-Indian and works to link indigenous interests with the larger concerns for the environment and the global climate. As the battle over TIPNIS raged, images of beautiful and vulnerable nature abounded in the 
massive poster production online and on the walls across the country. These were not the creations of CIDOB or the marchers but of the many allies, including students, artists, and environmentalist organisations. One iconic image was a poster that read: 'Is this really progress? Let's save TIPNIS.' The image shows the lush Amazon forest, with verdant trees and a brilliant blue sky, cut through by a highway. A huge leopard lies dead in the foreground, run over by an Sports Utility Vehicle. Here, nature, as represented by the tragic leopard, also stands in for the indigenous people of TIPNIS. The body of the lowland Indian and Nature itself are semiotically linked, tugging on the heartstrings of the audience. These posters and online images received a lot of attention, but indigenous organisers felt somewhat ambivalent about them. Marilín Karayuri explains:

\begin{abstract}
Yes, there was a lot of support (apoyo) and lots of images disseminated by people trying to support TIPNIS. But we the indigenous peoples don't need to see these cartoons, or see this on TV, because we live it.... It is not the same, but it is good to try to transmit what we in the world of the indigenous people live, and why we want to conserve nature... But we have always made clear: [These supporters] can speak, but not in our name! They are not authorized.... And many people have taken advantage of our situation to benefit their own struggles, to make themselves seen. (pers. comm. July 2016)
\end{abstract}

Karayuri has reason for her concerns. We have described how, as regional mestizo elites in Santa Cruz, the cambas, struggled against the Morales government, they adopted the lowland TIPNIS peoples as part of their struggle, calling attention to the wounded Indian-wounded Earth narrative. They characterised the violence committed against protestors as human rights violations, part of their broader campaign to destabilise the political power of the Morales regime (Fabricant and Postero 2013). By claiming the lowland Indian as their own, they could promote a regional narrative of autonomy. This became essential for protecting lands and natural resources in the lowland region of the country, where modernity or progress was not about an Aymara vision of capitalism but rather a lowland and mestizo vision tied to ideals of whiteness, a clean and 'rational' spatial order of the city of Santa Cruz (Gustafson 2006), and capitalist accumulation. In 2012, we witnessed a regional Cabildo, or mass public meeting, in the lowland capital of Santa Cruz, where elites used the TIPNIS struggle to push for regional autonomy. The TIPNIS representative, José Antezana, spoke to the cheering crowd. 
We have come as citizens to demand respect for democracy... It is the right and obligation of all of us Bolivians to defend this national park so that they do not destroy it with the highway the government wants to construct... But we are going to defend this territory. I assure you, brothers: the highway is not going to pass through TIPNIS even if THE GOVER NMENT INSISTS. This territory belongs to us, it is our right, we have legal title!

Here, we see the 'wounded TIPNIS' spokesperson as personifying the violations of human rights and the abuses of democracy. This worked powerfully for regional elites because it allowed them to link their cause to the human rights victims and the ethical substance of indigeneity. The elites see the region of Santa Cruz as a territorial body wounded by Morales' politics and by Aymara and Quechua invaders migrating to their region; that wound is echoed by the bodies of the many hunger strikers who protested against the state in 2008 pushing for departmental autonomy. However, it is not just the Right that makes these connections. In the 2014 political campaign, the Verdes (Green) party invited Fernando Vargas, the lowland indigenous leader of the 2011 march, to be its presidential candidate. Its campaign posters of endangered frogs made similar connections between environment, indigeneity, and human rights, challenging the MAS as authoritarian spoilers of the environment. This did not prove any more successful for the Verdes than it did for the Santa Cruz Civic Committee. The Verdes only won 3 per cent of the vote.

The last element of the TIPNIS narrative we point to is gender. If Morales used patriarchal and gendered discourses to push through the TIPNIS project, the protestors also used images of women to reinforce their performances of the good Indian. Lowland indigenous women were often strategically placed at the very beginning of the protest march. In part, their presence had such an impact because women appeared as both mothers and culture bearers marching to protect their children's human right to culture (Beaulieu 2014a; Engle 2010). But the marches increasingly featured women as leaders as well. In 2011, Justa Cabrera, the Guaraní leader of Confederación Nacional de Mujeres Indígenas de Bolivia (CENAMIB) - the women's organisation within $\mathrm{CIDOB}$ - whom we cited above, struggled to bring the voices of indigenous women into the public view. Having lowland indigenous women leaders was important, she said, because they 'represented a culture that should be valued by society, not as before when they were triply discriminated against for being a woman, indigenous, and poor' (Terrazas 2012). In 2012, TIPNIS march president Bertha Bejarano was increasingly 
thrust into the spotlight. A 47-year-old Moxeño activist, she was joined on the march by six of her ten children (See Achtenberg 2012). Some saw Bertha as a criminal, as, in 2007, she was detained for smuggling cocaine. Drug trafficking, is, of course, a serious issue in Bolivia, where coca growing is legal but highly regulated. In 2006, the Morales government began a 'Coca sí, Cocaina no' (Coca yes, Cocaine no) campaign, vowing to fight cocaine production, while continuing to support traditional production through a policy of strict 'social control' (Farthing and Kohl 2012). The MAS officials thus used Bejarano's conviction as a reason not to negotiate with her. The televised images of these women standing up to police and making demands to the MAS state telegraphed the strength of lowland indigenous women, as well as of the movement, in general, countering the dominant phallic practices of the state. Their images drew attention to the oppression they had survived. Yet, scholars make clear that these struggles are far from over in local communities, where women experience being silenced and discriminated against particularly in the political arena (see McNeish and Arteaga Böhrt 2013). Thus, TIPNIS performances showed only one side of indigenous women's struggles, pushing their efforts for gender equality aside to represent them primarily as warriors for the environment and their cultures, again reproducing dominant and one-dimensional narratives of gender and of indigeneity. We echo the critique that gender inequality in the community may have been obscured through these performances, but we also argue that the compelling images of indigenous women did work to decentre the masculine narrative of the government and create sympathy for the march (see Achtenberg 2012). Women's suffering during the march, which made for compelling media images, performed important semiotic and ethical work: it tied the unmarked everyday struggles of rural indigenous life - what Povinelli (2011) would call 'quasi-events' or endurance - to the monumental sacrificial 'event' of the march. As a result of these performances, members of the Bolivian public who normally would not take responsibility for the precarious situations these indigenous mothers live in as their lands are invaded by forest companies, mines and wells, or colonisers, suddenly found themselves forced to take an ethical position on the TIPNIS 'crisis'.

\section{Mujeres Creando: Performative Acts of Solidarity}

One important way this effect was amplified was through the work of $\mathrm{La}$ Paz-based anarcho-feminist collective Mujeres Creando, made up primarily of middle-class mestiza intellectuals who participate in a range of feminist 
and anti-poverty work, including graffiti commentary, performance, street theatre, and direct action (see http://www.mujerescreando.org). Their acts of solidarity with the TIPNIS marchers reinforced the eventfulness of the marches through street performances, spectacles, graffiti, and online discussions. Scholars have written about the ways in which Mujeres Creando used embodied performance in public spaces of La Paz to disrupt everyday forms of patriarchy (see Galindo 2012; Monasterios 2006). Thus, the audience for the performances we describe here was clearly the urban public of La Paz.

Once again, the indigenous leaders of the TIPNIS march were a little wary about other people making unauthorised representations of them. Some were uncomfortable with the gender politics of the group, who they saw as radical and extremist - something that had little resonance in lowland indigenous communities. Marilin Karayuri reported that the male leaders even jokingly told the indigenous women organisers not to get too close to these feminists, who might tempt them to rebel against the men, or worse, become lesbians. But in the end, they agreed that if they didn't interfere with the TIPNIS demands, or speak in their name, their support would be welcome (pers. comm. July 2016).

During the 2011 march, Mujeres Creando sprayed city walls with bright red paint representing the blood of TIPNIS and painted graffiti on city walls, with slogans such as 'Police, what kind of change is this? You teargased women and children.' Then, they created a massive street mural, welcoming the TIPNIS protestors when they arrived in $\mathrm{La} \mathrm{Paz}$ in September of 2012. At the top, they spray-painted 'Soy TIPNIS' (I am TIPNIS) below which they created three life-sized masks. The first mask is a tiger/cheetah with an open mouth. The text from their website reads, 'With animal skin, with animal force, with animal ferocity, I am Struggle.' The second is a green human face with a frog creeping across the nose and a pataju flower on its hat. This mask reads, 'With the green of plants, lungs to enable us to breathe, scream, sing and live. I am Hope.' The last mask is a blue face with birds and flowers on its forehead and a huge red tongue sticking out of a pink mouth. This mask reads, 'With the blue of water, the principle element of life, to stick out the tongue thirsty for justice, for laughter, for liberty. I am Liberty.' The accompanying text for the masks explains that 'this is not an anthropological or folkloric imitation of the use the inhabitants of the TIPNIS make of masks. We have allowed ourselves to make other, different masks, imagined from the ideas and sentiments that they are contributing on each of the days of their 
march. Imagination connects us!' Mujeres Creando hoped these images would inspire both the TIPNIS protesters and the residents of La Paz. Here again, Jasper's analysis of emotions become relevant. How and in what ways do these forms of protest and performance build 'emotive connectivity' across race, class, gender, and identity? We suggest that they were using these emotional tactics to build upon the 'moral shock' the TIPNIS controversy produced, drawing attention to the broader public's perceptions that the Morales administration's treatment of the TIPNIS protesters was unethical and authoritarian. This provided a space for larger national debates about the ethical substance of indigeneity.

Mujeres Creando used masks again the next year in the performance they called the 'March of the Bertas'. During the 2012 march, the government had vilified the march's leader, Berta Bejarano, bringing up her past criminal charge. Mujeres Creando took up her cause, with graffiti like 'Berta, being a [drug] mule doesn't annul you; We are one with you.' They also protested the consultation, with graffiti that became famous in its own right: 'Evo, your consultation insults all the people.' On 5 July 2012, when the march finally arrived in La Paz, Mujeres Creando led a march of indigenous women protesters, including Berta and her fellow lowland leader, Nazareth Flores, and urban residents who joined them on the way into Plaza Murillo, the plaza that houses the Parliament. These protestors carried signs that read 'For the Dignity of Women' and 'We are all Berta'. The participants held up life-sized photos of Berta Bejarano's face, forming masks that they wore over their own faces and on their hats. As police intercepted the march with large shields blocking roads, women pasted these photos on the shields. Eventually, the police denied them entry to the plaza, teargased them, and sprayed freezing cold water at them. This was a particularly violent tactic, given the difficulty these women from the tropics had in the frigid winter of La Paz. It also made clear that the state would go beyond the representational dimension to use state violence to gain control. Nevertheless, Mujeres Creando leader Maria Galindo concludes that the march was successful as it brought highland and lowland women together in protest, in contrast to Morales and his ministers who sought to divide and conquer. She defended their march against government accusations that they had acted as infiltrators by arguing that they had used Berta's face with her permission, and that she had participated in the march with gusto (pleasure). Most importantly, Galindo said, the march returned Berta to her rightful place as leader of the march, after the mainstream media had gone along with government accusations, sidelining her in favour of male leaders (Galindo 2012). 
We describe these creative performances because they show once again how the TIPNIS case became a site for very different political actors, each pushing their own interests. We have great respect for Mujeres Creando and see their performances as compelling attempts to provide an inspiring and creative vision of the environment, the fields of force facing indigenous peoples, and gender relations while posing a harsh critique of the MAS state. Yet, as they themselves admit, these are urban imaginaries produced by women with very different trajectories and interests from the indigenous women on the march. It is possible to see their acts of solidarity, in which they claimed, 'we are all Berta', as in fact producing the same sorts of dualisms that the state and the right-wing elite do: good Indians, who perform appropriately feminist gender relations, like Berta and the women leaders, and bad Indians, like the president, who don't. In what ways might this claim ignore the specific gendered inequalities that exist in rural indigenous communities like TIPNIS? Of course, this returns us to the age-old question that has bedevilled feminism: which women can speak for all women? Who is the 'we' in 'we are all Berta'? Here, we see contestations over the ethical substance of indigeneity being battled on the (fictional) faces and bodies of indigenous women, the material, and the discursive blending in performance. Representations of an indigenous woman (Berta), mistreated by the government, are worn on the faces and bodies of women who themselves suffer the impacts of government mistreatment. Both are material, and both form the basis of discursive contestation.

Each of these actors-the MAS, the right-wing Cruceños, and feminists-claims that the good indigenous people of TIPNIS belong to their virtuous half of a duality. The MAS state says they are part of the progressive modern plurinational state development project; the Right says they are part of the collective victims of the authoritarian state; and Mujeres Creando says they are part of the radical feminist project protesting the masculinist MAS state. While TIPNIS protesters might share some part of these different agendas, it is doubtful their positions can be distilled down this simply. As scholars have shown, indigenous women often articulate complex positions in which demands for women's rights emerge fromand not in opposition to-collective demands for indigenous rights (see Speed et al. 2006). But indigenous people are not dupes in this representational battle. As we have shown, the TIPNIS activists created their own dualisms, claiming they were part of the human rights project as well as the environmental project to save Mother Earth. In their discourse, in essence, they are saying 'we' are Mother Earth. Thus, each of these groups 
performs a 'we' that incites their audiences—be they the Bolivian public or the state itself - to ethical acts: supporting the government and the road, fighting the 'evil' state by embracing regional identity, struggling against patriarchy, or saving the planet and the forest by defending TIPNIS. Perhaps these very dualisms are necessary for movements to rally support and gain international traction.

\section{Exercising State Power}

Describing these acts as performances may give readers a false impression of innocent or playful theatrical dramas in the public sphere. We want to make clear that these acts were anything but playful. Instead, they were tools in a serious political contestation between the powerful state, regional interests, NGOs, and relatively weaker lowland communities over the fate of their lands and the environment. Thus, the playing field for the representational battles was not a level one, and the state used all its tools to win, mounting a multipronged campaign to silence and undermine the TIPNIS protests and continue the national development project. We have already discussed the repression directed at the marchers in Chaparina in the 2011 march, when police violently assaulted the marchers, beating them and dispersing them into the forest. It was a watershed moment for Bolivia. This was the eighth indigenous march since 1990, all of which had been peaceful. Never before had the state used violence against the marchers, even when the state was run by neoliberal white/mestizos. Marilín Karayuri expresses a commonly held lowland response to the Chaparina. Years later, she says, she is still deeply hurt (dolida). 'How is it possible that a president who makes himself known as indigenous, or at least acts in the name of indigenous people, did this? How can he call himself indigenous while he is repressing indigenous people?... It has left many people permanently marked.... It is like you are in shock' (pers. comm. 11 July 2016). Here, we come face to face with the ethical substance of indigeneity as a site of both moral reflection and governance. Morales claims to orient the new plurinational state around this revaluation of indigenous bodies and lives, but Karayuri calls the morals of this administration into question, lamenting his conduct, and making clear the effects of this failure on real people's lives.

Then, in 2012, the government again used violent force to support the CIDOB takeover that forced Adolfo and his followers to the vigil in the plaza. Our Guaraní friends who witnessed it remain traumatised to this 
day. Roberta and her husband, a leader in the organisation, lived in a small house on the headquarters' property. She had just given birth to twins and was recovering from her Caesarean section when the newly elected leaders forced their way in, assisted by police firing teargas. When she and other members tried to oppose them, they were beaten, their hair was pulled, and they were knocked to the ground. Roberta, sobbing at the betrayal, fled with only her babies clinging to her (pers. comm. August 2012). As Adolfo pointed out that day in the plaza, it was incredibly painful to lose the CIDOB headquarters, the 'house that had born witness to so many laws, so many triumphs for the indigenous movement' over the 30 years of its existence (pers. comm. August 2012). The new CIDOB president, Melva Hurtado, gave a press conference shortly thereafter, promising to work with the government towards 'development' for the region ( $\mathrm{La}$ Jornada 2012). Over the following year, the state used its other means to silence its opponents. In 2013, as McNeish and Arteaga Bohrt (2013) and Beaulieu (2014a) show, the MAS charged the old TIPNIS leaders, including Adolfo Chávez, with serious crimes and caused them to take refuge in an NGO until the Supreme Court overturned their cases. Morales called the protesters 'enemies' of Bolivia, accused them of being supported by US Agency for International Development (USAID), and thus being manipulated by the US government (Achtenberg 2011a, b). His government banned many foreign NGOs, including IBIS-Dinamarka, the Danish group that had provided infrastructural support to CIDOB for many years. On the other hand, the government 'invested' in embattled TIPNIS communities, paying indigenous leaders and buying outboard motors for community boats. The 'counter campaign' was covered by the media, while the old CIDOB was unable to get the attention they had had during the marches. 'Our hands were tied', says Marilín Karayuri. 'Facing their economic power, what could we do? We had no resources, no vehicles, no projects. We were completely blocked' (pers. comm. July 2016).

\section{Conclusion}

This was the context in which we found Adolfo Chávez, CIDOB's president, sitting in the plaza in 2012. Despite all the sacrificial marches, press conferences, and performances of the virtuous eco-Indians, and, despite support from environmentalists, feminists, lowland elite, international media, and even public opinion in La Paz, the TIPNIS marches had failed to meet their objectives. It is tempting to conclude that Adolfo and 
CIDOB failed because they were unable to embody the indio permitido, since they challenged extractivist development that is at the base of the government's 'economic liberation' agenda. That may be true, but we argue something different: their performances of the good Indian and the coercive and violent responses to it by the state made visible how indigeneity continues to be the ethical substance through which Bolivian society contests its past and creates its future. Thus, performance is a central site through which social worlds are articulated. TIPNIS made clear that the Bolivian state is willing to sacrifice lowland peoples to a model of development based on natural resource extraction, and that the majority of Bolivians-for now-will support the state. Yet, the performances we describe here presented indigeneity in a variety of ways, manifesting this ethical substance in ways that made visible the continuing tensions in Bolivian society, and also making clear the potentialities within these alternatives. State performances showed clearly what the indio permitido meant in this context: agreeing with extractivism. But this image of indigeneity was troubled by the other performances we describe. While some had critiqued the government's enactments of Andean cultural practices as being cynical and folkloric (Portugal 2015), the performances by the TIPNIS protesters and their allies, both environmentalist and feminist, articulated a clear picture of the state as an unethical betrayer of indigenous interests. By enacting their status as victims, the TIPNIS protestors made legible the fact that the state was committed to development at all costs, even if it meant undermining the rights to consultation and selfdetermination established in the new constitution. Their suffering made Morales look hypocritical and, particularly demonstrated that this new revolutionary indigenous state was, at its heart, not that different from all other states: willing to use its sovereign power to enforce control. Like Gandhi's hunger strikes, the performances of failed marchers acted as a mirror onto the social world Morales and his development agenda had created. It asked: what kind of state is this? What kind of ethics does it reflect? What kinds of suffering does it accept?

Our analysis of the TIPNIS protests also draws attention to the ways performances can redefine the categories under debate, acting as a site of politics. If, as Andrew Canessa (2014) has pointed out, indigeneity provided Evo Morales with the legitimacy to rule (ibid.: 17-18), then the failure to protect lowland indigenous communities and lands from rapacious development delegitimised and undermined his administration. But the protests also pointed out that indigeneity is not a neutral or static category; rather, it is multiple and under constant revision. In this case, the 
protests illustrated the malleability of indigeneity by highlighting the multiple constructed versions of indigeneity that offset and undermined the dominant narratives. As Marilín Karayuri, the Guaraní journalist indicated, not everyone on the march opposed development or even the construction of the highway. Some indigenous protestors were fierce advocates for the construction of the road. What protesters opposed was how the government used selected state authorised notions of indigeneity to push through its vision of national development. In contrast, the protesters' performances illuminated the fact that indigenous communities in the lowlands had been shut out of the decision-making process, which they framed as a violation of the ethical obligations of the indigenous state as well as fundamental to participatory democracy. So, in this case, lowland peoples used other images of indigeneity to stand up to the Aymara state, providing compelling images of noble and wounded Indians for the many sectors of Bolivia who were also opposing Morales.

Lastly, we see the ways in which the feminist group, Mujeres Creando, used lowland indigenous peoples as a means to 'out' the Morales government for its highly unethical but also hypermasculinist form of governance. If lowland indigenous protestors highlighted the multiple ways of being indigenous, then Mujeres Creando also pointed towards the multiple feminisms. Gender has permeated the discourses and enactments of colonisation and is inseparable from the coloniality of power. Yet, this gendered form of power is also asserted by a state led by an indigenous leader. By describing the gendered implications of the performances of both the state and its feminist critics, we draw attention to the complicated and fluid relation between ethnicity and gender, where gender can be a site of sovereignty, oppression, and resistance.

Performance made visible several things not previously legible, including the ongoing ethnic and gendered fragmentations and stratifications, the cracks and the breaks within the system. Through their performances, protesters contested state control over images and discourses of indigeneity/gender, battling over the ethical substance of indigeneity. If the state used monolithic visions of Aymara progress through development, notions of the lowland Indians resisting development flipped the 'passive Indian' into an active category undermining the power and authority of this hypermasculinist state. So, here, performance has the capacity to rewrite, to invert, to reverse age-old colonial representations of Indian versus white, of female versus male, and of development/progress versus backwardness, calling into being new social worlds. 
Acknowledgements This is a slightly revised version of a piece with the same title previously published in Anthropology Quarterly. We thank the journal for permission to reprint it here. We are especially grateful to the journal's anonymous reviewers whose thoughtful comments pushed us to clarify and deepen our arguments. Our manuscript benefitted from their very insightful critiques and suggestions, as well as those of the editors of this collection. We also thank Marilín Karayuri for her clarifying interview.

\section{REFERENCES}

Achtenberg, Emily. 2011a. Bolivia: Indigenous Groups to March Against TIPNIS Highway. NACLA, August 12. https://nacla.org/blog/2011/8/12/boliviaindigenous-groups-march-against-tipnis-highway. Accessed 7 Mar 2012.

. 2011b. Bolivia: TIPNIS Marchers Face Accusations and Negotiations. NACLA, August 26. https://nacla.org/blog/2011/8/26/bolivia-tipnismarchers-face-accusations-and-negotiations. Accessed 7 Mar 2012.

- 2012. Women in the Frontlines of TIPNIS conflict. NACLA, August 17. https://nacla.org/blog/2012/8/17/women-forefront-bolivia's-tipnisconflict. Accessed 9 Sept 2012. (No Longer Functional).

- 2014. Elections Revive Bolivia's Controversial TIPNIS Highway Plan. NACLA, September 4. https://nacla.org/blog/2014/9/4/elections-revivebolivia's-controversial-tipnis-highway-plan. Accessed 14 Sept 2014. (No Longer Functional).

- 2016. Evo's Bolivia at a Political Crossroads: Taking stock of Bolivia's changing political environment after Evo Morales' 2016 referendum defeat. NACLA Report on the Americas 48.4: 372-380.

Anderson, Benedict. 1983. Imagined Communities: Reflections on the Origin and Spread of Nationalism. New York: Verso Books.

Beaulieu, Devin. 2014a. Justice Over the Body: Human Rights and Indigenous Territory in the Bolivian Amazon. Presentation at the Conference on Human Rights and Humanitarianism, Davis, 25-26 April 2014.

. 2014b. Terrible Futures, Restorative Pasts, and the Impossible Present in Plurinational Bolivia. Paper presented at the Annual Meeting of the Latin American Studies Association, Chicago, 21-24 May 2014.

Beaulieu, Devin, and Nancy Postero. 2013. The Politics of Extractivism. Against the Current, November. http://www.solidarity-us.org/site/node/4032. Accessed 15 Sept 2014.

Cabrera, Justa, and Emidio Poiché. 2011. Message from TIPNIS to the World. YouTube, September 28 https://www.youtube.com/watch?v=uOlHVRnZVo Accessed 8 Nov 2013. 
Canessa, Andrew. 2005. The Indian Within the Indian Without: Citizenship, Race and Sex in an Andean Hamlet. In Natives Making Nation: Gender, Indigeneity, and the State in the Andes, ed. Andrew Canessa. Tucson: University of Arizona Press.

- 2014. Conflict, Claim, and Contradiction in the New Indigenous State of Bolivia. Critique of Anthropology 34 (2): 153-173.

CEPAL (Comisión Económicao para América Latina). 2012. Panorama Social de América Latina. http://www.eclac.org/piblicaciones/xml/1/45171/ PSE2011Panorama-Social-de America-Latina.pdf. Accessed 13 Nov 2014.

Cepek, Michael. 2016. There Might Be Blood: Oil, Humility, and the Cosmopolitics of a Cofán Petro-Being. American Ethnologist 43 (4): 623-635.

Conquergood, Dwight. 1991. Rethinking Ethnography: Towards a Critical Cultural Politics. Communication Monographs 58 (2): 179-194.

Corrigan, Philip, and Derek Sayer. 1985. The Great Arch: English State Formation as Cultural Revolution. Oxford/New York: Basil Blackwell.

de la Cadena, Marisol, and Orin Starn. 2007. Indigenous Experience Today. Oxford: Berg.

Defensor del Pueblo. 2011. Informe Defensorial: Respecto a la Violación de los Derechos Humanos en la Marcha Indígena. http://www.defensoria.gob.bo/

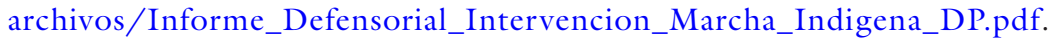
Accessed 5 Sept 2012.

EjuTV. 2017. Morales 'Tarde o Temprano Habrá Carretera por el TIPNIS'. http://eju.tv/2017/07/morales-tarde-o-temprano-habra-carretera-por-eltipnis/. Accessed 28 Nov 2017.

Engle, Karen. 2010. The Elusive Promise of Indigenous Development, Rights, Culture, Strategy. Durham: Duke University Press.

Fabricant, Nicole, and Nancy Postero. 2013. Performing the Wounded Indian: A New Platform for Democracy and Human Rights in Santa Cruz, Bolivia. Identities 21 (4): 395-411.

Farthing, Linda, and Benjamin Kohl. 2012. Supply-Side Reduction Strategies: Bolivia's Experiment with Social Control. International Journal of Drug Policy 23: 488-494.

- 2013. Mobilizing Memory: Bolivia's Enduring Social Movements. Social Movement Studies 12 (4): 1-15.

Foucault, Michel. 1991. On Governmentality. In The Foucault Effect: Studies in Government Rationality, ed. Graham Burchell, Colin Gordon, and Peter Miller. Chicago: University of Chicago Press.

Galindo, Maria. 2012. ¿Quién no tiene nada que ver con el TIPNIS? Crónica sobre la 'Marcha de las Bertas'. Mujeres Creando, July 7. http://www. mujerescreando.org/pag/activiades/2012/07-berta/07-berta.html. Accessed 20 July 2016. 
García Linera, Álvaro. 2013. Geopolítica de la Amazonía: Poder hacendalpatrimonial y acumulación capitalista. Vicepresidencia del Estado Plurinacional. http://comunicacion.presidencia.gob.bo/docprensa/pdf/20120911-10-5437.pdf. Accessed 1 Sept 2012.

- 2014. Identidad boliviana: Nacíon, mestisaje, y plurinacionalidad. Vicepresidencia del Estado Plurinacional. http://www.vicepresidencia.gob. bo/IMG/pdf/identidad_boliviana_.pdf. Accessed 7 Jan 2015.

Guss, David. 2000. The Festive State: Race, Ethnicity, and Nationalism as Cultural Performance. Berkeley: University of California Press.

Gustafson, Bret. 2006. Spectacles of Autonomy and Crisis: Or, What Bulls and Beauty Queens Have to Do with Regionalism in Eastern Bolivia. Journal of Latin American Anthropology 11 (2): 351-379.

Hale, Charles R. 2002. Does Multiculturalism Menace? Governance, Cultural Rights and the Politics of Identity in Guatemala. Journal of Latin American Studies 34 (2): 485-525.

- 2004. Rethinking Indigenous Politics in the Era of the 'Indio Permitido'. NACLA Report on the Americas 38 (2): 16-21.

Hall, Stuart. 1996. The West and the Rest. In Modernity: An Introduction to Modern Societies, ed. Stuart Hall, David Held, Don Hubert, and Kenneth Thompson. Malden: Blackwell Publishers.

Hirsch, Cecilie. 2012. Urfolk mot urfolk i Bolivia. Latin-Amerikagruppene i Norge Verdensmagasinet, December 7. http://www.latin-amerikagruppene. no/Artikler/13868.html. Accessed 20 July 2016.

Holston, James, and Arjun Appadurai. 1999. Introduction: Cities and Citizenship. In Cities and Citizenship. Durham: Duke University Press.

Huarcaya, Sergio. 2015. Performativity, Performances, and Indigenous Activism in Ecuador and the Andes. Comparative Studies in Society and History 57 (3): 806-837.

Hymes, Dell. 1981. In Vain I tried to Tell You: Essays in Native American Ethnopoetics. Philadelphia: University of Pennsylvania Press.

Jasper, James M. 1998. The Emotions of Protest: Affective and Reactive Emotions in and Around Social Movements. Sociological Forum 13 (3): 397-424.

Joseph, Gilbert M., and Daniel Nugent. 1994. Everyday Forms of State Formation: Revolution and the Negotiation of Rule in Modern Mexico. Durham: Duke University Press.

Kaijser, Anna. 2014. Who Is Marching for Pachamama? An Intersectional Analysis of Environmental Struggles in Bolivia Under the Government of Evo Morales. PhD Diss, Centre of Excellence for Integration of Social and Natural Dimensions of Sustainability, Lund University.

Kohl, Benjamin, and Linda Farthing. 2012. Material Constraints to Popular Imaginaries: The Extractive Economy and Resource Nationalism in Bolivia. Political Geography 31: 225-235. 
La Jornada. 2011. Evo advierte al Tipnis que construirá carretera "quieran o no quieran”. La Jornada, June 30. http://www.jornadanet.com/n.php?a=64900-1. Accessed 7 Mar 2012.

. 2012. Eligen a Melva Hurtado como nueva presidenta de la CIDOB. July 11. www.jornadanet.com/n.php?a=79072-1. Accessed 19 Jan 2017.

La Prensa. 2011. Roberto Coraite de la CSUTCB afirmó que desea que la carretera evite que los indígenas del TIPNIS vivan como indigentes. La Prensa, June 9. http://www.laprensa.com.bo/diario/actualidad/bolivia/20110906/robertocoraite-de-la-csutcb-afirmo-que-desea-que-la-carretera-evite-que_5690_9859. html. Accessed 12 Sept 2014.

La República. 2006. Bolivia: Morales homenajeó al indigena Tupac Katari. La Republica, April 15. http://www.larepublica.com.uy/mundo/229721-boliviamorales-homenajeo-al-indigena-tupac-katari. Accessed 9 Sept 2008.

Laing, Anna. 2015. Resource Sovereignties in Bolivia: Re-conceptualising the Relationship Between Indigenous Identities and the Environment During the TIPNIS Conflict. Bulletin of Latin American Research 34 (2): 149-166.

McNeish, John Andrew. 2013. Extraction, Protest and Indigeneity in Bolivia: The TIPNIS Effect. Latin American and Caribbean Ethnic Studies 8 (2): 221-224.

McNeish, John Andrew, and Ana Cecilia Arteaga Böhrt. 2013. Accumulated Rage: Legal Pluralism and Gender Justice in Bolivia. In Gender Justice and Legal Pluralities: Latin American and African Perspectives, ed. Rachel Seider and John Andrew McNeish. New York: Routledge.

Meister, Robert. 2011. After Evil: A Politics of Human Rights. New York: Columbia University Press.

Mendoza, Zoila S. 2000. Shaping Society Through Dance: Mestizo Ritual Performance in the Peruvian Andes. Chicago: University of Chicago Press.

Mendoza, Luz. 2011. Mujeres: Evo es machista al pedir enamorar a indígenas para dividir el TIPNIS. Erbol, August 2. http://eju.tv/2011/08/mujeres-evo-esmachista-y-patriarcal-al-pedir-enamorar-a-indgenas-para-dividir-el-tipnis. Accessed 6 Feb 2013.

Monasterios, Elizabeth. 2006. No pudieron con nosotras: El desafio del feminismo autónomo de Mujeres Creando. La Paz: Plural.

Morsolin, Christian. 2015. Mensaje contracorriente del Papa Francisco. America Latina en movimiento, October 7. http://www.alainet.org/es/articulo/171016. Accessed 28 June 2015.

Portugal, Pedro. 2015. Revés autonómico indígena pachamamista en Totora Marka. Pukara 111: 8.

Postero, Nancy. 2007. Andean Utopias in Evo Morales's Bolivia. Latin and Caribbean Ethnic Studies 2 (1): 1-28.

. 2013. Protecting Mother Earth in Bolivia: Discourse and Deeds in the Morales Administration. In Environment and the Law in Amazonia: A Plurilateral Encounter, ed. J.M. Cooper and C. Hunefeldt. Brighton: Sussex Academic Press. 
2017. The Indigenous State: Race, Politics, and Performance in Plurinational Bolivia. Oakland: The University of California Press.

Postero, Nancy, and Nicole Fabricant. in press. Indigenous Sovereignty and the New Developmentalism in Plurinational Bolivia. Anthropological Theory.

Postero, Nancy, and Mark Goodale. 2013. Revolution and Retrenchment: Illuminating the Present in Latin America. In Neoliberalism, Interrupted: Social Change and Contested Governance in Contemporary Latin America, ed. Nancy Postero and Mark Goodale. Stanford: Stanford University Press.

Povinelli, Elizabeth. 2011. Economies of Abandonment: Social Belonging and Endurance in Late Liberalism. Durham: Duke University Press.

Speed, Shannon, R. Aída Hernández Castillo, and Lynn Stephen. 2006. Dissident Women: Gender and Cultural Politics in Chiapas. Austin: University of Texas Press. Stephenson, Marcia. 1999. Gender and Modernity in Andean Bolivia. Austin: University of Texas Press.

Terrazas, Alexander. 2012. La defensa del Tipnis mostró su valor. Mujer indígena oriental, el nuevo rostro de la rebeldía. Notibolivia, March 8. http://www. notiboliviarural.com/index.php?option=com_content\&view=article\&id=1987:ladefensa-del-tipnis-mostro-su-valormujer-indigena-oriental-el-nuevo-rostro-de-larebeldia\&catid=303: actualidad\&Itemid=555. Accessed 25 July 2016.

Turner, Victor. 1988. Anthropology of Performance. New York: PAJ Publications. Viveiros de Castro, Eduardo. 1998. Cosmological Deixis and Amerindian Perspectivism. Journal of the Royal Anthropological Institute 1998: 469-488.

Warren, Sarah. 2009. How Will We Recognize Each Other as Mapuche? Gender and Ethnic Identity Performances in Argentina. Gender \& Society 23 (6): 768-789.

Weismantel, Mary. 2001. Cholas and Pishtacos: Stories of Race and Sex in the Andes. Chicago: University of Chicago Press.

Open Access This chapter is licensed under the terms of the Creative Commons Attribution 4.0 International License (http://creativecommons.org/licenses/ by $/ 4.0 /$ ), which permits use, sharing, adaptation, distribution and reproduction in any medium or format, as long as you give appropriate credit to the original author(s) and the source, provide a link to the Creative Commons license and indicate if changes were made.

The images or other third party material in this chapter are included in the chapter's Creative Commons license, unless indicated otherwise in a credit line to the material. If material is not included in the chapter's Creative Commons license and your intended use is not permitted by statutory regulation or exceeds the permitted use, you will need to obtain permission directly from the copyright holder.

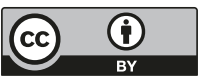




\section{INDEX $^{1}$}

A

Absorption, 76, 88

Accounting, 16, 35, 208

Accumulation

by dispossession, 16, 132

by diversion, 119-137

Agency, 27, 39n15, 56, 104, 112,

$156,159,168,170,183,230$

Amazonia

Ecuadorian Amazonia, 58, 77

Peruvian Amazonia, 31, 53-69

Andes, xii, 2, 4, 18, 19, 21, 33, 36, $75,82-84,102,103,107-110$, $120,121,131,134,135,143$,

$144,146,148-150,156-158$, 160n2, 165-170, 175,

180-184, 186n3, 224-227, $234,238,247$

Animism, 4-6, 37n2

Anthropocene, 2, 3

Appropriation, v, xi, 57, 61, 67,

146, 177, 182, 202, 204, 209,

210,240 n6
Apus, 18, 130, 133, 137nl, 151, 158, 169,185

Audit, 208

Ayllu, 167, 177

Aymara, xi, 25, 33, 120, 125, 131, $135,16 \ln 3,248,254,257-259$, $262,263,271$

B

Biodiversity, 16, 33, 35, 36, 195-211, 223

Body, xi, 10, 32, 54, 55, 57, 61, 64, 70n6, 106, 112, 113, 126, 130, 133, 201, 222-224, 248, 250, $253,260,263,267,268$

Bolivarianism/the Bolivarian Revolution, 77, 79, 82, 87 Bolivia, v, viii, ix, xi, xiii, 2, 14, 24, 31 , $33,36,37 \mathrm{n} 6,120-122,127-129$, 137n3, 138n11, 148, 227, 245-271

Brazil, vi, ix, x, xiii, 14, 35, 36, 198, $202,221,230,232-238,255$

${ }^{1}$ Note: Page numbers followed by 'n' refer to notes.

(C) The Author(s) 2019

C. Vindal Ødegaard, J. J. Rivera Andía (eds.), Indigenous Life

Projects and Extractivism, Approaches to Social Inequality and

Difference, https://doi.org/10.1007/978-3-319-93435-8 
C

Capitalism, 3, 10, 16, 20, 21, 23-26, $31,120,125-127,132,136$, $238,250,251,255,262$

Carbon, 16, 33, 35, 36, 37n6, 195-211

Care, 31, 57-59, 63, 65, 67, 69, 87,

$135,157,158,170,181-183$, $202,230,252$

Chavez, Hugo, 77, 78, 81, 87

Child, vi, vii, 61, 63, 64, 68, 85-87, $103,129,171,180-182,201$, $236,247,256,263-265$

Class, xi, 7, 21, 22, 26, 36, 99, 126, $147,148,254,258,266$

Climate change, xiv, 19, 25, 151, 155, 156,255

Coloniality, 146, 250, 271

Commodities, ix, xi, 13-15, 17, 33, 119-122, 125-132, 134-137, 207,211

Communal councils, 80, 81, 88 comunidades campesinas,

$$
\text { 166, 167, } 174
$$

Compassion, 32, 87, 88

Conflict, v, viii, xiii, 14, 17, 18, 34-36, $54,111,119,122,125,136$, $145,157,159,167,197,198$, 219-224, 226, 227, 232, 233, 238, 240nl1, 240nl2, 24lnl3, $246,247,257$ social, 19, 34, 170, 171

Conservation, 35, 195-211, 261

Contrabandistas, 33, 100, 119-137

Control, x, xii, 20, 31, 32, 36, 56-59, 62, 63, 66-68, 95-98, 100-102, 107-109, 112, 119, 122, 126-128, $130,152,154,166,168,170$, 175-177, 181-183, 197, 205, 255, 257-260, 264, 266, 270, 271

Conviviality, 88

Corporations, 18, 25, 53, 62, 64-66, $145,154,155,167,183,221$, $224,254,258$
Cosmopolitics, 19, 24-29, 34, 106, 165-185

Culture, xii, xiii, $3,4,12,22,23,29$, $38 \mathrm{nl} 3,78,79,171,183$, 195-211, 225, 236, 263, 264

D

Discourses, 2, 4, 20-22, 25, 26, 83, $96,106,119,120,122,134$, $136,146,149,156,160,170$, $172,221,223,226,230,232$, $249,255,258-260,263$, 267,271

Disposable populations, 56

Domestication, 132, 181, 202, 203

E Earth, 2, 82-86, 107, 133, 137nl, $145,150,152,157,158,169$, 182,227

earth-beings, 5, 8, 17-19, 33, 34, $120,125,130,132-134$, $136,137 \mathrm{nl}, 144,146$, $148-152,159,185,212 \mathrm{n} 7$, 222, 240n 8

Ecosystem services, 199, 207

Ecuador, 2, 14, 16, 24, 31, 32, 37n6, $58,59,95-113$

Energy, 13, 15, 24, 37n6, 38nl4, $120-124,127,235$

Environment

environmental degradation, 13, 19, $53,68,75$

environmentalism, 25, 225

Ethnography, xi, 1-7, 10-13, 18, 19, 22, 24-26, 30, 33-36, 38n10, $77,82,87,106,113,126,131$, $148,160 \mathrm{n} 2,165,166$, $168-170,175,178,180-185$, 201, 212n9

Exclusion, 8, 17, 55, 56, 59-62 
Extraction, v, vii-ix, xiii, 8, 13-18, 25,

$31,32,34,36,37 \mathrm{n} 7,53,54$,

59-61, 65-68, 75-77, 79, 81-88,

96, 97, 101, 111, 113, 119, 120,

$122,124,125,127,128$,

134-136, 145, 173, 184, 220,

$221,223,227,232,234,238$,

254,270

Extractivism, v-xiv, 1-36, 76, 77, 108,

$119,120,133,143-160,165$,

$166,169,173,186 \mathrm{nl}, 220,222$,

$223,225,239,250,252,255$,

$256,259,270$

spectral extractivism, 165-185

F

Flow, xii, 31, 32, 95-113, 121,

125-127, 130-137, 149,

153,154

Folklore, 265, 270

Forest, vi, 16, 32, 33, 35, 36, 57-60, 64, 66, 67, 70n9, 76, 82, 95, 97, 103-105, 110, 195-208, 211, $21 \ln 1,222,247,255,256,259$, 260, 262, 264, 268

Fuel, 16, 33, 39n16, 80, 88, 119-125, 127-131, 136, 138nl1

Fujimori, Alberto, 122, 123, 154

\section{G}

Gas, 14, 36, 37n6, 65, 95, 120-124,

$137 \mathrm{n} 6,137 \mathrm{n} 7,138 \mathrm{n} 8$

natural, 122-124, 127

Gasoline, 61, 70nl1, 79, 80, 82,

88,104

Gender, xiii, 7, 36, 222, 230, 248, $249,259,263-267,271$

Gold, v, ix-xi, 32, 75-89, 148, 173, 196, 197, 211, 220, 224, 227, 232,236

Grassroots projects, 80
H

Highland, vi, viii, 20, 33-35, 83, 120, $121,125,131,143-145,147$, $148,155,156,158,159,16 \ln 4$, $172,219,220,225,246,248$, $253,258,259,261,266$

I

Inclusion, 3, 5, 8, 9, 18, 38n10, 59, 69,78

Indigeneity, xi, xiii, xiv, xvn7, 1, $19-26,31,35,36,125,146$, $170,172,219-239,245-271$

Indigenous, v, 1-36, 54, 75, 95, 124, $144,166,195,220,245$

Inequality, 4, 20, 21, 24, 29, 33, $38 \mathrm{nl} 1,88,121,131,132,136$, $137,183,185,264,267$

Informality, 33, 131

Infrastructure, v, 55, 58, 64, 70n10, $98,101,113,124,127,130$, $136,143,144,149,150,153$, $154,156,157,159,198,206$, 207,223

Irrigation, 36, 143-145, 149-151, $153,154,156,160 \mathrm{nl}, 167$, 173,223

L

Lakes, 63, 83, 150, 151, 169, 183, $224,228,237$

Land

claim, 34, 145, 157, 159, 208, 209

landscape, xii, 2, 8, 9, 15-17, 24, $26,27,31,33,36,53,67$, $82,102,108,123,126,133$, $134,137 \mathrm{nl}, 144,145,151$, $171,173,220-221$, 224-226, 235

rights, 38n8, 82, 96, 99, 112, 197-201, 205, 207 
Law, 9, 16, 38n8, 62, 64, 89n5, 153,

$154,175,199,224,234,236$,

$239,246,250,254,269$ water, $147,154,157$

Life, viii, ix, xii, xiii, 3-8, 15-17, 24, $31,55,56,58,59,61,69,77$, $79,82,83,86,98,99,103,106$, $111,120,125,126,151,152$, $156,174,175,178,179,181$, $183,184,199,210,224,225$, $231,232,234,236,240 \mathrm{n} 10$, $249,250,260,264,265$

Life projects, 3, 27-30, 32-34, 37nl,

$133,136,143-160,184$

life making projects, $1,2,9,10,24$, $27,30,36,77,89,100,120$, $127,135,136,144,146,149$, $160,220,222,239$

Lowland, vi, xiii, 20, 75, 83, 88, 103, $108,171,182,245-248$, 255-264, 266, 268-271

M

Manufactured goods, v, 86

Map, mapping, 77, 204-206, 208-211 Market, vii, x, xii, 9, 15, 16, 20, 27, 33, $37 \mathrm{nl}, 76,87,120,121,123,127$, $129,131,135,145,146,151$, $154,158,195,199,205$, 207-208, 246, 249, 252, 255, 256

Measurement, 154, 155, 173, 207-210 Metals, v, 14, 16, 37n6, 54, 62, 80, 173,220

Mining, 13, 14, 17, 18, 24, 26, $32-35,37 \mathrm{n} 7,65,75-89,95$, $122,123,125,137 \mathrm{n} 4,159,166$, $167,169-174,178,183,195$, $196,207,211,219-239$ conflicts, 14, 18, 159, 170

Modernity, 4, 8-10, 20, 24, 26, 144, $146,154,184,259,260,262$
Morales, Evo, xi, 25, 36, 246, 248, $250,252-264,266,268-271$

Multiculturalism, 4, 251

Multiplication, 31, 33, 67, 132, 136

$\mathbf{N}$

Narratives, 24, 25, 33, 38nl 1, 76, $152,166,172,223,226-228$, $232,249,252,254,255,257$, 259-264, 271

Nature, 1, 3-5, 8, 17-19, 23-29, $37 \mathrm{n} 3,87,125,131,132,134$, 136, 143-146, 149, 154, 155, $157,165,169,172,183,196$, 198, 201, 209, 219-239, 247, $248,256,260-262$

Negotiation, viii, xii, 1, 19, 27, 37n3, $63,68,83,100,103,104,107$, $109,110,153,155,167,170$, $171,200,257,264$

Neoliberalism, 23, 158, 251, 252

Nongovernmental organisations (NGOs), x, xii, 22, 25, 26, $35,101,109,110,196$, 200, 205-207, 210, 221, $225,230,251,256,258$, 268,269

Nonhuman beings, 2, 8, 34, 57, 82,145

\section{O}

Oil, 14, 15, 31, 32, 34, 37n6, 37n7, 39nl6, 53-69, 75-89, 95-113, 120-122, 127, 130, 137n5, 145, 173,246 extraction, 14, 31, 32, 37n7, 53, 59-61, 66-68, 76, 83, 111,173

Ontogeny, 179, 212n8

Ontography, 11-13, 185 
Ontology, 3, 5-7, 9-12, 19, 23, 26, 28, 29, 37n3, 107, 166, 167, $169,179,236$

Ownership, v, xii, xiii, 17, 31, 33-35, 53-69, 98, 101, 145, 157-159, 165-185, 195-211, 240n8

P

Pachamama, 133, 137nl, 151, $16 \ln 3,169,224,226,239 \mathrm{n} 4$

Pachatierra, 169

Participatory democracy, 78, 81, 257,271

Performance, xiii, xiv, 28, 36, 167, 222, 24lnl6, 247-255, 258-261, 263-271

Peru, vi, viii, 13, 17, 31, 33-35, 37n6, $53,58,64,83,96,111,114 \mathrm{n} 3$, 119-125, 128-130, 137, 137n3, 137n5, 143-160, 165-185, 219, $220,226,229,233,238,240 \mathrm{nl} 2$

Petro-citizenship, 79

Petro-state, 32, 76, 80, 88

Place, vii, viii, xi, 2, 9-11, 19, 29, 31,

34, 35, 38nll, 39nl5, 55-59, 66, $67,76,77,81,83,98,111,125$, 126, 128-131, 133, 134, 137n2, 138n10, 150-152, 155, 157, 158, $16 \ln 4,168,171,175,180-183$, 197, 200-205, 208, 210, 211, 219-239, 249, 250, 266

Politics, viii, ix, 1, 2, 6-11, 15, 18-29, $77,99,121-127,131,136$, $137,157,159,173,183,196$, $205,220,238,239,247-253$, 265,270

political recognition, 78,79

Practices, xi, 2-5, 7, 8, 16-20, 28, 29, $31,33,34,36,38 n 12,53-56$, 58, 60-62, 65, 66, 78, 89n5, 89n6, 99, 101, 104, 107, 121,
$122,125,128,130,131$, 133-137, 144-146, 148-152, $154,156,157,159,160,165$, $166,171,172,175,181,184$, $200,205,207,222,223,225$, 226, 232, 234, 237, 238, 250, $251,253,264,270$

Progress, xii, 9, 13, 17, 33, 56, 119, 120, 134-136, 144-147, 149, $155,159,160,259,260,262,271$

Property, 34, 55-58, 64, 65, 67, 68, $83,98,107,108,153,154,157$, $158,166,178,199,201-207$, 210, 211, 228, 230, 231, 239, 269

See also Ownership

Prospecting, ix, 75, 200, 201, 205

Protestors, 219, 24ln13, 256, 259, 261-263, 265, 266, 270, 271

Q

Quechua, 25, 33, 34, 58, 70n4, 89n7, $120,122,124,125,131,168$, $180,257-259$

$\mathbf{R}$

REDD+, 195-211

Resistance, vii, viii, xiv, 18, 19, 21, 24, $25,27,29,32,33,35,36,76,79$, $87,99,110,112,185,219-239$

Resource

curse, 173

extraction, v, 13, 18, 25, 34, 36, 75, $76,82,87,96,97,101,113$, $184,195-211,221,222,254$, 255,270

Ritual

offerings, 36

religious rituals, 172

Rubble, 31, 36, 55, 56, 62, 68

Ruination, 31, 53-69 
$S$

Sacrifice zones,

$$
24,31,55,56
$$

Sanema, 31, 32, 76-88, 89n3

Saramaka, 199, 200, $21 \ln 2$

$$
\text { p. Suriname, } 199
$$

Sharing, xiii, 86, 87, 120, 130, 134,

$$
136,150,219
$$

Sieko-pai, 31, 32, 96, 105, 114nl

Socialities, $32,33,87,120$,

$$
125,126,130-132 \text {, }
$$$$
135,136
$$

South-South Activism, 232-237

Stabilisation, 18

Stories, 83, 101, 106, 108, 148, 149, 219-239

Subordinate, 28, 181, 260

Suffering, 20, 29, 30, 59, 64,

$$
\begin{aligned}
& 65,68,85-87,239,253, \\
& 264,270
\end{aligned}
$$

Suriname, 33, 35, 196-200, 202, 205-207, 211-212n2, 212n3, $212 \mathrm{n} 12$

Surveying, 166, 196, 197, 207-209

Swidden, 56, 57, 59, 60, 66, 201-203, 206

$\mathrm{T}$

Toxic waste, $31,54-56,61$, 66-69, 228

Translation, 33, 35, 37n4, 37n5, $39 \mathrm{nl} 6,58,120,121,126$,
$127,132-136,16 \ln 3$,

$179,222,225,226$

Trio, 33, 35, 198, 201-206, 208-211, 212n3

V

Value, xii, xiv, 16, 17, 25, 33, 34, 120, $126,134,136,144-146,149$, 154-157, 159, 181, 198, 201, 204-208, 211, 232, 247, 250, 254

Venezuela, 14, 15, 37n6, 77

Vengeance, 85

Violence, 59, 250, 252, 258, 259, $262,266,268$

W

Wamani, 169

Water

extractivism, vi, 16, 143-160, 223

law, 153, 157

resources, x, 34, 143-160, 223

water-beings, 104, 146,

$$
151-154,160
$$

Wayana, 206, 210, 211, 212n3, $212 \mathrm{n} 13$

Wealth, v, x-xii, 17, 31-33, 59, 61, $62,66,67,75-89,119-137$, $172,196,210,254$

World

worlding, 33

world-making practices, 2 